Universidade de Brasília

Instituto de Ciências Sociais

Departamento de Sociologia

Programa de Pós-graduação em Sociologia

Gilvan Gomes da Silva

Políticas de Segurança Pública: Um olhar sobre a formação da Agenda, das Mudanças do padrão de policiamento e da Manutenção do Policiamento Comunitário no Distrito Federal 
Gilvan Gomes da Silva

\section{Políticas de Segurança Pública: Um olhar sobre a formação da Agenda, das Mudanças do padrão de policiamento e da Manutenção do Policiamento Comunitário no Distrito Federal}

Tese apresentado como parte dos requisitos para obtenção para o título de doutor pelo Programa de Pós-Graduação em Sociologia da Universidade de Brasília. 


\section{Políticas de Segurança Pública: Um olhar sobre a formação da Agenda, das Mudanças do padrão de policiamento e da Manutenção do Policiamento Comunitário no Distrito Federal}

Tese apresentado como parte dos requisitos para obtenção para o título de doutor pelo Programa de Pós-Graduação em Sociologia da Universidade de Brasília.

Orientador: Prof. Dr. Arthur Trindade M. Costa

Banca Examinadora

Prof. Dr. Arthur Trindade M. Costa (UnB)

Profa. Dra. Analia Laura Soria Batista (UnB)

Profa. Dra. Haydée Glória Cruz Caruso (UnB)

Prof. Dr. Paulo Carlos Du Pin Calmon (UnB)

Prof. Dr. Almir de Oliveira Junior (IPEA) 
Dedico a Minha Véia e Ao Meu Véio, Seu Escorinho (in memoria) 


\section{Agradecimentos}

Aos meus pais, pelo esforço do meu pai José Jerônimo, saudoso Seu Escurinho, que não letrado ensinou-me o valor da palavra e da audição e ir buscar a pena, a tinta e o papel para dominar o que não pôde ter, a letra; e pela dedicação da minha mãe Maria Lúcia, guerreira que, pelo seu exemplo de vida e amor mais que maternal, não me permiti desistir; sendo a minha primeira orientadora de como pensar a sociedade e como agir nos conflitos vividos e esperados, sendo a semente da minha vida acadêmica. Agradeço às minhas irmãs Jeovânia, Gislene e Jaqueline pela ajudas "voluntárias" e pela paciência diária. Ao meu irmão Cristiano, protetor na infância e que de alguma forma está presente nas preocupações no processo de construção dos objetos de pesquisa. Ao meu filho Daniel. À Sheila, meu amor, pelas compreensões e apoio nos momentos de depressão e mau humor, caminhado lado a lado comigo e me orientando nas decisões mais difíceis.

Aos amigos de infância Franscilei Francisco, Gicélio, Marcelo Cipreste, Klans Otoniel, Rafael Santos, Gean Francesco e tantos outros que, nas rodas de discussão, ensinaram-me o quão é importante o debate e as ideias diferentes no processo de construção individual. Aos amigos que, de uma forma ou de outra, contribuem para a construção do meu conhecimento acadêmico e me apoiaram, em especial os amigos Christyne Carvalho e Aluísio Junior.

À Tia Renilda, Aparecida e família (Elizon, Elizandra, Adizon e ao saudoso Seu Adir), Dona Cleuza, Dona Neném, Dona Zezé, Tia Penha, Dona Ana, Lourdes e Liu, Dona Isabel e tantos outros familiares da rua que moro e fizeram parte da minha primeira socialização e ensinaram-me pensar sobre o que a academia chama de solidariedade, comunidade e tantos outros conceitos que utilizo na tese.

Aos amig@s que conheci nas Ciências Sociais Cristiano Dourado, Bernardo Perondi, Leonardo Leocádio, Gláucia, Rafael, Renata Florentino, Ludmila Gaudad, Miryan Mastrella.

Aos amigos que conheci na Polícia Militar no início da carreira Paulo Moura, Juscimar França, Davi Fidel, David, Cleuton Barbosa, Gilney, Rogério Targino e vários outros que em suas palavras e ações me apoiaram na construção da tese. 
Aos colabores do Instituto de Ciências Policiais da Polícia Militar do Distrito Federal, em especial aos amig@s Alda, Alessandro Rezende, Edilson, Marcos Nunes (que aprendi admirar pela humildade) e ao amigo João Carlos pelo constante apoio. Ao Capitão Senna pelos debates e pela ajuda na pesquisa.

À amiga Solange de Carvalho Lustosa, pelo apoio incondicional, principalmente por incentivar e estar ao lado nos momentos mais difíceis e que a cada dia

Aos amig@s que conheci no trabalho a irmã Gilvanir, Simone, Lucas Cavalcante, Sérgio e tantos outros que diariamente colaboraram com debates diários em suas salas de aula e fizeram-me perceber questões relevantes ao tema de políticas pública, comunidade, redes, entre outros. Ao amigo Cleuber pelo debate teórico que iniciou o debate sobre política há três anos.

Aos membros da banca Professor Pedro Calmon, Professora Haydée Caruso e Professor Almir Júnior pela dedicada leitura e atenciosas críticas que contribuíram para compreender e repensar a problemática e os resultados da tese.

Aos colaboradores do Departamento de Sociologia e Antropologia da Universidade de Brasília, Edilva Silva, Patrícia Rodrigues e Leonardo. Aos professores Brasilmar Nunes, Cristiane Girard, Henyo Trindade, Carlos Benedito, Ana Liési, Maria Stela, que fazem parte do tronco da minha carreira acadêmica, tendo como atuação marcante a professora Lourdes Bandeira, primeira orientadora, professora Analia Soria Batista, orientadora do mestrado e Professor Arthur a quem agradeço pelos direcionamentos da tese, pelos ensinamentos acerca do mundo acadêmico que sempre levarei para as salas de aula, congressos, orientações e bancas e principalmente pelas palavras de incentivo que fez-me acreditar na consolidação da tese.

E a tod@s aquel@s que de alguma maneira contribuíram direta ou indiretamente para a construção do objeto, a problematização, a imersão teórica, a produção e análise dos dados, a produção da tese e os debates finais, meu muito obrigado. 


\section{Resumo}

Este trabalho tem como objeto de análise as interações sociais que influenciaram o processo de formulação e de implementação da Política de Segurança Pública Policiamento Comunitário no Distrito Federal a partir de 2007, sob a gestão do Governador José Roberto Arruda (DEM). Para tanto, foram analisados os atores envolvidos, a concepção inicial dos formuladores do programa, as metas estabelecidas e quais as ações foram realizadas para a Implementação da Política Pública. O método utilizado foi a etnografia centrada na observação participante das interações policiais militares para compreender o habitus policial militar e a percepção construída sobre a doutrina e a estratégia de policiamento comunitário; em entrevistas semiestruturadas com atores políticos e especialistas que tiveram atuação no processo de agenda, implementação e manutenção da política; e na análise documental que orientou as condutas policiais militares e reestruturou o organograma da PMDF para implementar o policiamento comunitário em seu quadros por força de convênio entre o Governo do Distrito Federal o Ministério da Justiça. As redes constituídas regional e nacionalmente possibilitaram que houvesse condições de implementação da política, todavia, não havia a previsão da mudança estrutural da cadeia hierárquica típica das instituições militares para distribuir o poder de decisão para os policiais militares executivos do policiamento comunitário. Verificou-se que há uma gradação da mudança da percepção do que é policiamento comunitário pelos policiais militares e as poucas ações motivadas para buscar maior legitimidade da ação policial e maior proximidade dos policiais militares com a comunidade policiada foram pontuais, pautando-se por esforços individuais por não haver uma prática institucionalizada de consolidação do Policiamento Comunitário no Distrito Federal na PMDF. O insucesso da implementação da política se deu pela não continuidade da convergência dos fluxos (indicadores de problemas favoráveis, legitimidade da solução e apoio político); pela impossibilidade de monitorar e avaliar a execução da política por não haver metas e indicadores; por não ter sido considerado o habitus policial militar que privilegia um capital social do ethos guerreiro, que conta com um dispositivo de recompensa pelo reconhecimento policial que orienta suas ações para a produção de indicadores já consolidados como essenciais para a manutenção da segurança pública, próprios do policiamento tradicional.

Palavras-chave: Políticas de Segurança, Policiamento Comunitário, Habitus Policial. 


\begin{abstract}
Abstratct
This project is a subject of analysis of social interactions that influenced the process of formulation and implementation of public safety Politics community law enforcer program in Distrito Federal starting in 2007, under the management of Governor José Roberto Arruda (DEM). For such, it was analyzed the actors involved, the initial conception of the program`s formulators, the goals established and which actions were taken for the implementation of this Public Politic. The method utilized was the ethnography centered on the observation of military police interaction participating to comprehend the habitus military police and the perception built over the doctrine and the strategy of community law enforcer; On semi structured interviews with politician actors and specialists who have acted in the process of agenda, implementation, and political maintenance; and in the documental analysis that oriented the military police conducts and re-structured the organogram of PMDF to implement the law enforcer on its chart by force of agreement between the Government of Distrito Federal and the Ministry of Justice. The networks established regionally and nationally allowed that there were conditions of Political implementation, however, there wasn't any prediction to change the structure of the chain of command, typical of military institutions to delegate decision power to the executive military police of the law enforcer. It has been analyzed that there is a gradation of the perception`s view of what really is law enforcer for the military police and the few motivated actions to search for more legitimacy for the military police action and greater proximity of the military police with the law enforcer were great, based on the struggle of individuals for not having an institutionalized practice of consolidation of the law enforcer program in Distrito Federal in the PMDF. The failure of the Politics implementation were due to the not continuation of the convergence of flow (indicators of favorable problems, legitimacy of solution and political support); Based of the impossibility of monitor and evaluate the execution of the Politics for not having goals and indicators/ for not being considered the Habitus of the military police that benefits a social capital ethos guerreiro, that is aligned with a reward for police acknowledgment that guides their actions to the production of well-established indicators as essential for the maintenance of Public Safety, proper of conventional policing.
\end{abstract}

Key-words: Safety Politics, Law Enforcer Program, Police Habitus 


\section{Résumé}

Ce travail a pour objet d'analyse les interactions sociales qui ont influencé le processus d'élaboration et implémentation de la Politique de Sécurité Publique «Policiamento Comunitário » dans la région du Distrito Fédéral (Brésil) depuis 2007, sous la direction du gouverneur José Robertu Arruda (DEM). Pour ce faire, nous avons d'abord établi une cartographie des acteurs engagés dans le processus. Ensuite, nous avons analysé la conception initiale formulée par les responsables du programme, ainsi que les objectifs définis et les mesures prises pour la mise en œuvre de cette Politique Publique. La méthode utilisée pour la réalisation de ce travail de recherche a été l'etnographie axée sur l'observation participante des interactions des policiers de la police militaire. Notre but était de comprendre le habitus policier, ainsi que la perception autour de la doctrine et de la stratégie de police communautaire. Les réseaux établis au niveau régional et national ont contribué à l'existence des conditions permettant l'implémentation de cette politique, néanmoins, cela n'a pas été prévu de modifier la chaîne hiérarchique typique des institutions militaires afin de distribuer le pouvoir de décision entre les policiers responsables de la mise en œuvre du programme de police communautaire. Nous avons vérifié que, parmi les policiers, il existe une gradation dans le changement de la perception de ce qui est la police communautaire. Les quelques actions motivées par la recherche d'une plus grande légitimité de l'action des policiers, ainsi qu'une plus grande proximité des policiers avec la communauté surveillée, ont été ponctuelles et se sont basées sur des efforts individuelles, ce qui nous permet de conclure qu'il n'y a pas de pratiques institutionnalisées permettant la consolidation du programme de police communautaire dans la région du District Fédéral. L'échec de l'implémentation de la politique est du a la non continuité de la convergence des flux (des indicateurs sociaux favorables, la légitimation de la solution et le soutien politique), ainsi que par l'impossibilité de surveiller et d'évaluer l'exécution de la politique, une fois qu'il n'existe pas d'objectifs et d'indicateurs. Un autre facteur ayant contribué à l'insuccès de l'implémentation de cette politique c'était l'absence de prise en considération du habitus policier militaire - qui privilégie le capital social du ethos guerreiro et compte sur un mécanisme de récompense par la reconnaissance policière qui guide les actions du policier vers la production des indicateurs déjà consolidés comme essentiels pour la manutention de la sécurité publique, ce qui est propre à la police traditionnelle.

Mots-clés: Politique de sécurité, Police communautaire, Habitus Policier. 
Lista de Tabelas, Quadros, Gráficos, Figuras e Fotografias

\author{
Tabelas
}

Tabela 1 Índice de Desenvolvimento Humano do Distrito Federal e de algumas RA em

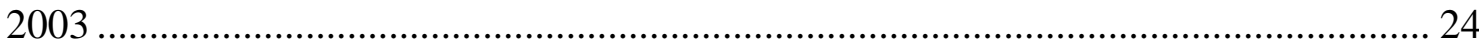

Tabela 2 Valores Absolutos de incidência de crimes no Distrito Federal ...................... 61

Tabela 3 Taxas de Ocorrências de crimes por 100.000 habitantes. Distrito Federal ..... 62

Tabela 4 -Crimes violentos registrados no Distrito Federal de 2005 a 2013 ............... 156

\title{
Quadros
}

Quadro 1 - População do Distrito Federal em 2004 .................................................... 22

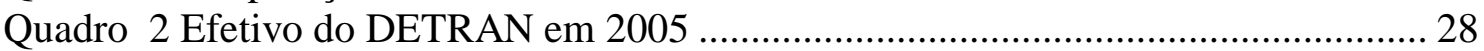

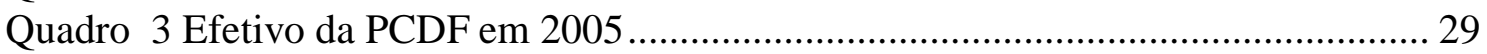

Quadro 4 Distribuição do efetivo da PCDF nos Departamentos ................................... 30

Quadro 5 Distribuição do Efetivo e Viaturas do Departamento de Polícia

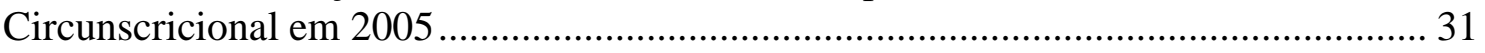

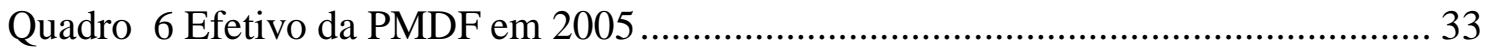

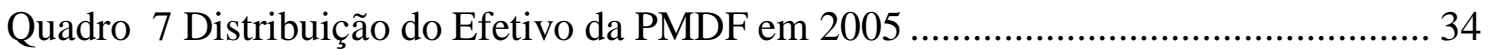

Quadro 8 Distribuição do Efetivo da PMDF disposto em unidades de atividades fim em

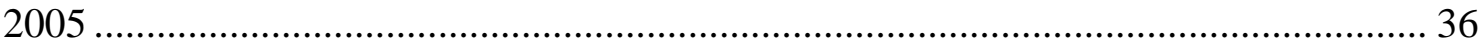

Quadro 9 Distribuição do Efetivo policial nas Unidades Especializadas ...................... 37

Quadro 10 Número de Homicídios nas Regiões Administrativas do DF entre 2004 e

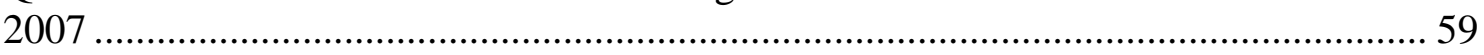

Quadro 11 Número de Homicídios nas Regiões Administrativas do DF entre 2004 e

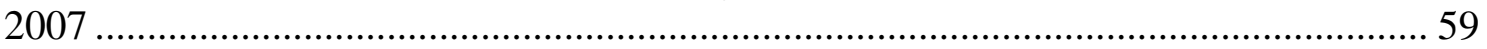

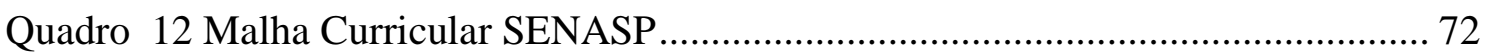

Quadro 13 Currículo do Curso de Policiamento Comunitário ....................................... 97

Quadro 14 Regiões Administrativas do Distrito Federal em 2007 ................................ 98

Quadro 15 Regiões Administrativas aglutinadas para a implementação do Policiamento

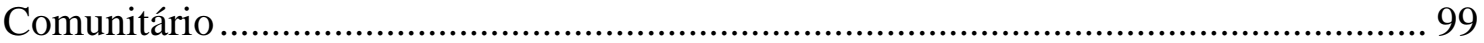

Quadro 16 Relação de postos por habitante nas áreas das Administrações Regionais

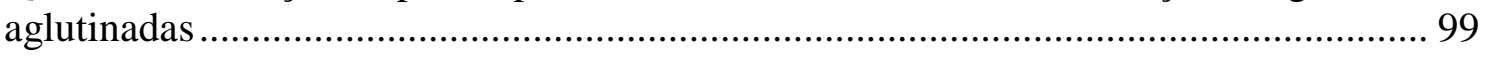




\section{Gráficos}

Gráfico 1 - Taxas de mortalidade por homicídio. Brasil e Distrito Federal 1980-2000. 57

Gráfico 2 - Taxas de Mortalidade por homicídio .......................................................... 58

Gráfico 3 Distribuição das Matrículas em Cursos Ead da SENASP por Ano ................ 71

\section{Figuras}

Figura 1 Concentração de Homicídio em 2004. Distrito Federal ..................................... 60

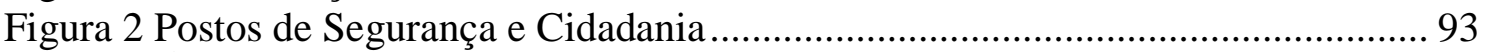

Figura 3 Área de Análise objeto de instalação do Posto de Referência ....................... 103

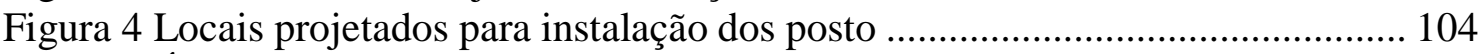

Figura 5 Áreas de Atuação e responsabilidade dos Postos de Segurança e Cidadania 105

Figura 6 Área de Atuação dos Postos na Visão de Saturação ..................................... 106

Figura 7 Áreas de Saturação de Policiamento de Segurança e Cidadania..................... 107

Figura 8 Posto Comunitário de Segurança. Módulo Simples........................................ 118

Figura 9Posto Comunitário de Segurança. Módulo Composto .................................... 119

Figura 10- Estrutura Organização da PMDF, nível Departamentos e Diretorias ........ 135

Figura 11Estrutura do Departamento Operacional da PMDF .................................... 139

\section{Fotografias}

Fotografia 1 Posto Comunitário de Segurança em 2008

Fotografia 2 - PCS 001, após a instalação do segundo módulo, seis anos após a inauguração

Fotografia 3 PCS 115. Cidade Estrutural. ................................................................. 163

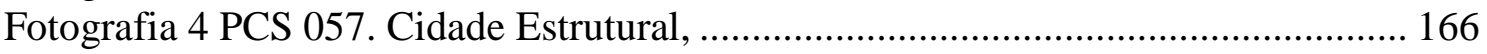




\section{Lista de Siglas}

BPM - Batalhão de Polícia Militar

CONSEG - Conselho Comunitário de Segurança

CPCAS - Centro de Polícia Comunitária e Ações Sociais

CPCDH - Centro de Polícia Comunitária e Direitos Humanos

CPMInd - Companhia de Polícia Militar Independente

DER - Departamento de Estrada e Rodagens

DETRAN - Departamento de Trânsito

DF - Distrito Federal

DOp - Departamento de Operação

PCDF - Polícia Civil do Distrito Federal

PCRS- Programa Comunitário de Referência Social

PCS - Posto Comunitário de Segurança

PMDF - Polícia Militar do Distrito Federal

PSC - Posto de Segurança e Cidadania

RA - Região Administrativa

SENASP/MJ - Secretaria Nacional de Segurança Pública

SUPROC - Sub Secretaria de Programas Comunitários 


\section{SUMÁRIO}

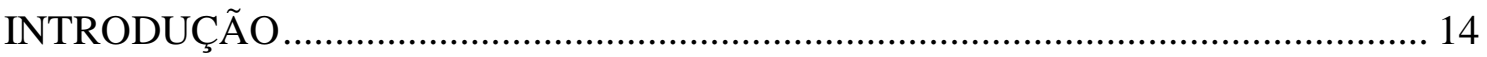

O Sistema de Segurança Pública no Distrito Federal .................................................... 21

Os muros da/na Polícia Militar do Distrito Federal......................................................... 38

CAPÍTULO 1 - AS POLÍTICAS PÚBLICAS: ATORES E FLUXOS DE

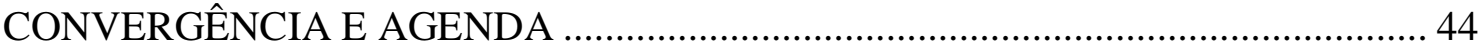

1.1 O PROCESSO DE AGENDA E FORMULAÇÃO DE POLÍTICAS PÚBLICAS . 50

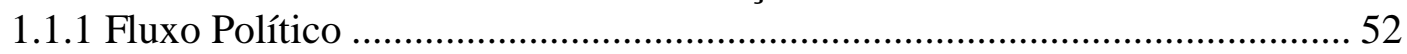

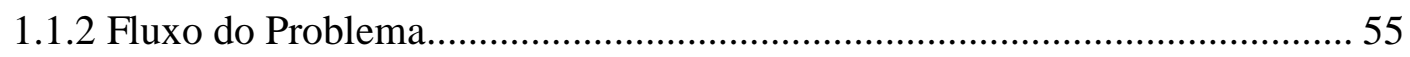

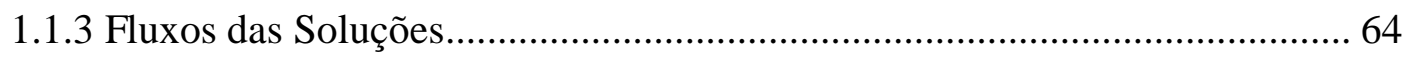

CAPÍTULO 2 O PONTO ÍGNEO DA AGENDA DE SEGURANÇA PÚBLICA ....... 82

2.1 A PROPOSTA CONSTRUÍDA EM PERÍODO DE ELEIÇÕES............................. 85

CAPÍTULO 03 - POLÍTICAS DE SEGURANÇA PÚBLICA: COMO AS POLÍTICAS

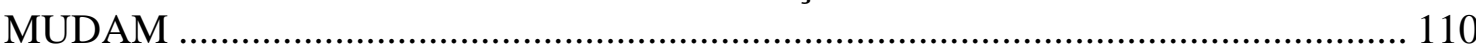

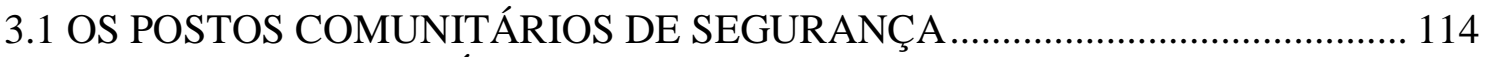

3.2 O HABITUS E AS PRÁTICAS INSTITUCIONAIS …....................................... 128

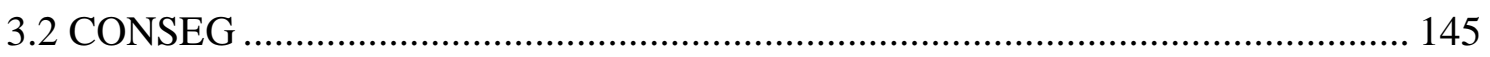

04 - POLÍTICAS PÚBLICAS DE SEGURANÇA: COMO AS POLÍTICAS

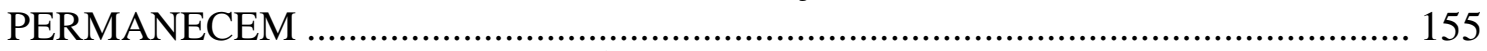

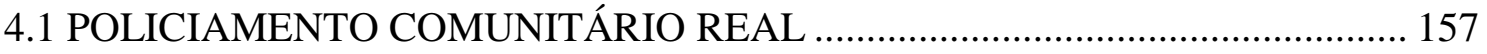

4.1.1 O abandono: quando os policiais não querem e a população não quer ....... 159

4.1.2 Grupos policiais tentam convencer a população a querer ........................... 167

4.2 FATORES EXÓGENOS AO CAMPO DE CONTROLE: AS CONSTRUÇÕES

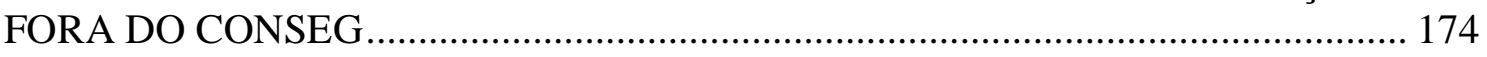

4.2.1 Entrando na Redes Sociais ................................................................. 177

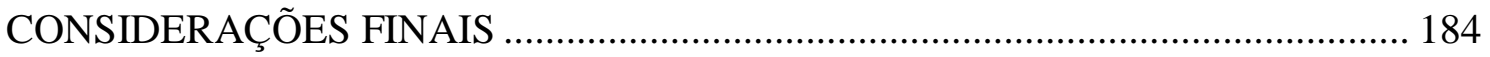

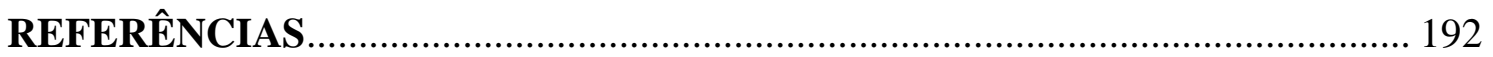




\section{INTRODUÇÃO}

Nas últimas décadas do século XX vários modelos de interação social e de soluções de demandas sociais institucionalizados foram modificados por muitos fatores. A compreensão das motivações das modificações, das características e dos possíveis resultados exige uma análise complexa, principalmente porque os analistas são contemporâneos a estas modificações e, de certa forma, estão sendo modificados e estão modificando os modelos analisados.

Este trabalho faz parte do esforço de refletir sobre os processos de mudança institucional na Polícia Militar do Distrito Federal (PMDF). O nosso objeto de estudo é o processo de formação da agenda e a implementação do policiamento comunitário na gestão do Governador José Roberto Arruda em 2007, assim como a manutenção desta política de segurança até o fim do Governo Agnelo Queiroz, em 2014.

Cabe ressaltar que já havia ações governamentais anteriores ao período analisado que promoviam o policiamento comunitário como, por exemplo, a criação dos Conselhos de Segurança em algumas Regiões Administrativas do Distrito Federal ou a oferta de cursos para os agentes de segurança pública desde 1990, como serão demonstrandos posteriormente. Estas práticas estavam direcionadas para os gestores das unidades e para alguns policiais que poderiam multiplicar a nova doutrina. Todavia, o período e a política analisados circunscrevem a proposta para que todos e todas policiais militares convergissem para uma mesma prática policial.

Este trabalho apresenta especificamente a análise de como o modelo de policiamento comunitário foi inserido na agenda de políticas públicas; a descrição dos atores que estavam envolvidos no processo de formulação do Programa; a análise da concepção inicial dos formuladores do Programa sobre Segurança Comunitária ao proporem o programa; as análises das metas que os formuladores almejaram com o programa; as análises das ações que foram realizadas para a implementação do programa; e a relacionação das ações estabelecidas na política pública com a percepção de Segurança Comunitária inicial durante o planejamento.

$\mathrm{O}$ argumento central da tese está abalizado em três eixos:

a) A formação da agenda dessa política pública foi condicionada pela dinâmica eleitoral do Distrito Federal. Inicialmente o policiamento comunitário era uma promessa de campanha e não um projeto de política pública; 
b) A implementação do programa foi mediada pela atuação de especialistas do Ministério da Justiça, da Secretaria de Estado de Segurança Pública do Distrito Federal e da PMDF, bem como pelos interesses político-partidários; e

c) O resultado desse processo foi a implantação de quase um terço do total de postos comunitários, sem que fosse elaborado um projeto mais abrangente que previsse o emprego e a distribuição do efetivo, seu treinamento e equipamentos, seus objetivos, metas e indicadores de resultado.

Obviamente, além do campo acadêmico, a definição de agenda, a identificação de alternativas, a avaliação e a seleção das opções, bem como a implementação das políticas públicas e, especificamente, da política de segurança pública perpassam pelo pressuposto de que há interrelações de diferentes instituições governamentais, com diferentes níveis de decisões, pois o capital social de determinadas agências "legitima" poderes no processo decisório da formulação de políticas públicas por deterem o monopólio das possíveis soluções.

Ao nos dedicarmos a esse tema, empenhamos esforços para analisar a política que focou uma instituição de segurança pública, mas sem perder de vista o campo de controle social para explicar essa inter-relação. Portanto, o foco da pesquisa científica foi a relação institucional da Polícia Militar - instituição total ${ }^{1}$ (GOFFMAN, 2003) com tradições policiais e militares arraigadas em códigos e em ações nos espaços públicos e privados com o Governo local e a sociedade civil. Todavia, o pano de fundo é a governabilidade e a gerência sobre instituições da segurança pública.

Inicialmente, estudar esses fatores contribui para descortinar o conhecimento institucionalizado ou axiomático das agências de controle do delito acerca das causas da criminalidade no Distrito Federal. Outra contribuição é conhecer os processos sociais e os atores responsáveis que classificam quais são as políticas públicas agendadas para determinadas localidades, quais os crimes que são objetos das políticas públicas e qual a representação que os formuladores de políticas públicas têm da ordem social, além do nível de governabilidade local.

Além da contribuição teórica no campo sociológico, há a contribuição social que o trabalho pode oferecer à sociedade já que ainda não há unanimidade quanto ao controle

\footnotetext{
${ }^{1}$ Para Erving Goffman (2003:13), as instituições totais separam grande quantidade de indivíduos com situação semelhante da sociedade por diversos instrumentos, levando uma vida fechada e formalmente administrada.
} 
da criminalidade no Brasil e, especificamente, no Distrito Federal. Há diversas formas de controle dentro de uma limitação legal federal, estadual e municipal que são interpretadas pelas instituições policiais, militares, acadêmicas, religiosas, entre outras instituições que contribuem para o controle social.

Várias teorias contribuíram para a compreensão do processo analisado. Inicialmente, destacamos a contribuição de Harold Lasswell (1971), de Sjöblom (1984), de Worthen et al (2004), de Farias e Filgueiras (2007), de Dye (2010), de Cohn, March e Olsen (1972) ao analisarem os atores políticos, os ciclos das políticas públicas, a atenção dos governos aos problemas e a atuação dos grupos de interesse. Todavia, a contribuição basilar da tese está calcada na Teoria dos Múltiplos Fluxos de Kindgon (1984) por demonstrar que o processo de formação da agenda governamental nem sempre está em um processo linear problema - solução - formulação. O que importa neste processo, nesta perspectiva, é a confluência dos fluxos que serão demonstrada durante toda a apresentação da tese.

Outras percepções auxiliaram na compreensão do processo de implementação e manutenção da política pública. Estudos sobre as características do trabalho policial (COSTA, MUNIZ, 1999) e acerca do policiamento comunitário (SKOLNIK e BAYLEY, 2002 e 2001; ROSENBAUM, 2002;) possibilitarem descortinar questões elucidativas para esta fase da política de segurança. Todavia, foi a partir da percepção de Pierre Bourdieu (1996, 2001 e 2006) que auxiliou compreender as possíveis "resistências e aderências" a nova política. Mapear o campos social e compreender o habitus policial militar do Distrito Federal foram algumas etapas da pesquisa que estas percepções teóricas possibilitaram.

A etnografia foi nossa guia. Por isso, os pronomes pessoais condutores da narrativa demonstram quando a fala é do pesquisador-policial militar produtor de dados (expresso na primeira pessoa do singular) e do pesquisador-analista que está "sobre os ombros dos gigantes" que contribuíram para a análise dos dados (expresso na primeira pessoa do plural). A produção dos dados foi realizada concomitantemente com a minha carreira policial militar.

Ser pesquisador social e policial militar ao mesmo tempo foi essencial para poder observar a influência das redes no processo de agenda e implementação da política 
pública. Ingressei na Polícia Militar em 1999 e participei do Curso de Formação de Soldados com duração de aproximadamente onze meses. Digo aproximadamente porque não há uma regulamentação para determinar qual o período mínimo de formação. Após o curso de formação, trabalhei no $11^{\circ}$ Batalhão de Polícia Militar, responsável pelo policiamento ostensivo na cidade de Samambaia. Um ano depois, trabalhei no $2^{\circ}$ Batalhão em Taguatinga. Novamente, mudo para outra unidade, desta vez sou transferido para uma unidade policial especializada porque gostaria de trabalhar perto de casa. As unidades especializadas $^{2}$ têm como área de atuação todo o Distrito Federal, assim, a meta era mudar para uma unidade especializada em policiamento de trânsito de rodovias distritais, a CPRv. Após cinco anos de serviço policial rodoviário, peço transferência para a unidade ordinária de policiamento da cidade em que resido. A partir de 2005 resido e trabalho na mesma cidade.

Todas essas transferências contribuíram para minha formação policial, foram diversos tipos de modalidade de policiamento no turno noturno. Todavia, o crescimento não foi apenas relativo à atividade policial militar. Esse espaço me propiciou um local de observação privilegiado. Como salienta Simmel (1983):

\footnotetext{
Somente quando estamos próximos, do lado de dentro, iguais, é que podemos conhecer e compreender; somente quando a distância impede contatos imediatos, em todos os sentidos da palavra, é que temos a objetividade e a imparcialidade, tão necessários quanto o conhecimento e a compreensão. (Simmel, 1983: 100)
}

Enquanto policial militar, do lado de dentro de determinada equipe de representação, foi possível ter acesso aos bastidores de determinados espaços e reconhecer as redes com maior facilidade. A relação insider e outsider foi um instrumento utilizado para produzir as informações necessárias para compreender o fenômeno. A proximidade com o objeto permitiu ter acessos a setores governamentais e a pessoas chaves na administração para poder construir uma narrativa linear dos fatos.

Entretanto, foi como pesquisador que pude reconstruir a minha própria narrativa na Polícia Militar do Distrito Federal, muito semelhante aos dos demais policiais militares e compreender as complexas redes em que transitava. Neste momento, ao observar as

\footnotetext{
${ }^{2}$ A distinção entre unidade de policiamento ordinária e policiamento especializada será apresentada ao descrever as unidades e efetivos da PMDF.
} 
minhas relações profissionais de outrora, assim como as dos demais policiais com quem eu convivia, torno-as objeto de análise.

Eu estava em um turbilhão de acontecimentos sem perceber que os movimentos dos fluxos de agenda e de implementação convergiam e divergiam a todo o momento em minha frente. Estava sendo acionado, compartilhava, era ouvido e ouvia, apresentava e era apresentado às inovações que somente agora, com a pesquisa, pude entender o fluxo de informações que passavam em frente aos meus olhos e não sabia para que: apenas vivia. Era a vida cotidiana, agora transmutada nas letras dos dados científicos. Muitos desses dados estão presentes nas entrelinhas de alguns trabalhos já apresentados para outras questões como, por exemplo, a representação social do outro (o suspeito) pelo policial militar (SILVA, 2009a), a identidade policial militar e os espaços públicos e privados (SILVA, 2011), as práticas de policiamento comunitário no Distrito Federal (SILVA, 2009b), a gestão e produção de dados que no processo de decisão e construção de ações, programas e políticas de segurança pública (SILVA, 2014), dentre outras.

Todavia, foi na releitura dos cadernos de campo que pudemos reconstruir o objeto em questão. Portanto, rememorar fez a reconstrução do tempo cronológico (CARDOSO, 2005) com o tempo de lembranças dos policiais militares acerca de suas atuações diárias, a qual vivência, o tempo de agenda e o tempo da implementação do policiamento comunitário no Distrito Federal. Além disso, não se trata de um processo de reconstrução do tempo ao pesquisador, mas no pesquisador (PEIRANO, 1995:22).

Mesmo trabalhando há mais de dez anos na PMDF, durante a pesquisa sentia-me mais cientista que policial. Todavia, apesar de ser um "nativo", estava em um determinado espaço do campo próprio da minha posição profissional e da minha posição na escala hierárquica da instituição. Participava das interações de representação policial militar-sociedade, nas interações face-a-face com a comunidade local. Frequentava a fachada e os bastidores dessa representação ${ }^{3}$. Tinha a linguagem, os códigos próprios do grupo; o acesso a maioria dos espaços dentro das viaturas, nos postos policiais, às conversas dos policiais, entre outras informações pertinentes à pesquisa.

\footnotetext{
${ }^{3}$ Para reflexões sobreo processo de análise sociológico que envolve a analogia das representações sociais nas fachadas e nos bastidores, ver Goffman, 1975
} 
Frequentei cursos na modalidade presencial e à distância ministrados por policiais militares do Distrito Federal ou por convênio entre a Secretaria de Segurança do Distrito Federal e a Secretaria Nacional de Segurança Pública do Ministério da Justiça. Este foi o momento que conheci a doutrina do Policiamento Comunitário e que simpatizei por estreitar laços sociais com a sociedade policiada. Esta era a percepção construída que eu tinha após a conclusão do curso de Promotor de Policiamento Comunitário: um modo de policiar com respeito à comunidade.

Mas a pesquisa necessitava também dos espaços, das representações dos comandantes e da esfera política. A graduação de soldado não me credenciava para esse acesso. Assim, para complementar essas informações, a pesquisa foi dividida em duas etapas distintas, todavia, em alguns momentos concomitantes na construção de instrumentos e de produção de dados.

A primeira fase estava focada no processo de Formulação da Política Programa de Segurança Comunitária ${ }^{4}$ para a PMDF. Nesta etapa, foram realizadas análises documentais da Legislação Nacional e Distrital acerca do tema. Também foram analisados os Projetos de Leis apresentados na Câmara Legislativa do Distrito Federal em 2005, ano anterior ao processo de formulação do programa de policiamento comunitário. As portarias da Secretaria de Segurança do Distrito Federal de 2005 até 2010 também foram analisadas, bem como as portarias e Diretrizes da Polícia Militar do Distrito Federal referentes ao Policiamento Comunitário; o último documento analisado nessa etapa foi o Projeto de campanha política do Programa Comunitária de Referência Social.

As entrevistas semiestruturadas foram utilizadas para compreender o que a observação participante e a análise documental não conseguiram captar nesta etapa. Para tanto, alguns atores foram selecionados por terem trabalhado em postos-chaves durante $o$ processo de formulação. Assim, foram entrevistados os ex-coordenadores de Polícia Comunitária da Secretaria Nacional de Segurança Pública (SENASP) do Ministério da Justiça (MJ); o ex-Coordenador de Polícia Comunitária da Secretaria de Estado de Segurança Pública (Subsecretário da SUPROC) do Distrito Federal; e oficiais e praças policiais militares envolvidos diretamente no processo.

\footnotetext{
${ }^{4} \mathrm{O}$ nome Programa de Segurança Comunitária foi dado à política de implementação do policiamento comunitário, todavia, estava implícito que não era apenas para ser executada pela PMDF, mas por todos os seguimentos da Segurança Pública do Distrito Federal
} 
A segunda fase da pesquisa focou o momento da Implementação da Política Programa de Segurança Comunitária para a PMDF. Nesta fase a análise documental teve como objeto os convênios da Secretaria de Segurança Pública do Distrito Federal com a SENASP; a observação participante das reuniões nos Conselhos Comunitários de Segurança e as entrevistas semiestruturadas com policiais militares foram realizadas nas cidades de Brazlândia ${ }^{5}$, Ceilândia ${ }^{6},{\text { Lago } \text { Sul}^{7} \text { e Estrutural }}^{8}$.

A informação do objeto da pesquisa, assim como o objetivo, foram disponibilizados para todos os policiais militares. Todas as informações do trabalho de campo são informações que foram obtidas no espaço público, isto é, aqueles espaços que qualquer cidadão, com um pouco mais de atenção ou com o olhar "direcionado" poderia captar. A publicação de todos os nomes citados no trabalho foram autorizados e, para aqueles que não autorizaram ou que entendemos que não fossem necessárias a identificação, as informações que pudessem identificar o entrevistado foram omitidas, assim, ao invés de identificar o quartel da Região Administrativa, foi trocada esta informação por unidade policial militar, por exemplo, ou oficial 1 e oficial 2, praça 1 ou praça 2 .

A construção e apropriação dos dados se deram de forma contrária à sua apresentação neste trabalho. A produção dos dados iniciou-se focando a manutenção da política, após a implementação e depois a formação da agenda de segurança pública. A lógica foi conhecer e analisar as informações da última gestão até o ponto ígneo da política pública.

A primeira entrevista foi realizada com ex-coordenadores de Polícia Comunitária da Secretaria Nacional de Segurança Pública do Ministério da Justiça, ex-chefes do Centro de Polícia Comunitária e Direitos Humanos da PMDF, e Diretores de Formação da Polícia Militar. Apesar de termos planejado direcionar a entrevista para a fase de implementação da política, recebemos informações importantes sobre o processo de construção da agenda também. Recebi a recomendação de alguns oficias da PMDF para entrevista o Oficial $1^{9}$ para compreendermos melhor a fase anterior à implementação da

\footnotetext{
${ }^{5}$ Primeira cidade que teve o policiamento Comunitário implantado e que tem o Posto Comunitário de Segurança 001

${ }^{6}$ Cidade mais populosa do Distrito Federal

${ }^{7}$ Cidade com a maior Renda Per Capita do DF e com o maior IDH no Brasil

${ }^{8}$ Região com a Menor Renda Per Capita e menor população no Distrito Federal

${ }^{9}$ A descrição do entrevistado policial 1 e das suas contribuições serão apresentadas no decorrer da tese.
} 
política. E dessa forma, um entrevistado indicando outros, foi possível puxar o fio condutor da pesquisa e desenrolar o novelo de informações, sendo possível ainda vislumbrar as redes constituídas por agências do Governo Federal e do Governo do Distrito Federal em que vários "nós" constituintes das redes são os agentes de segurança pública e outros são atores políticos.

Todavia, como foi informado anteriormente, a apresentação desses dados seguem a sequência temporal para facilitar o entendimento. Assim, após as considerações iniciais, o segundo capítulo do trabalho apresenta o processo de formulação da agenda de segurança pública, descrevendo os atores e as interações que compuseram o fluxo político, o fluxo dos problemas e o fluxo das soluções. No fluxo das soluções há também a apresentação dos processos de convencimento que cada ator disponibilizava para que sua solução se destacasse das demais. O capítulo encerra apresentando a proposta de política pública para a segurança pública que foi formulada em 2006 por uma equipe de especialistas quando houve a convergência dos fluxos que possibilitaram o espaço de debate sobre Segurança Pública no Distrito Federal.

No terceiro capítulo descreve-se o processo de implementação propriamente dito, destacando-se os três pilares da Política de Segurança Pública: a instalação de 300 (trezentos) postos comunitários no Distrito Federal; o estímulo à participação da sociedade para identificar os problemas de segurança pública, analisar quais as melhores ações, auxiliar nas ações escolhidas e avaliar o resultados deste processo; e a mudança das práticas policiais ao fomentar a aproximação com a comunidade local e a mudança de procedimentos.

O quarto capítulo apresenta uma descrição da manutenção da política pública no Distrito Federal. As apropriações do conceito e as diversas práticas são exemplificados juntamente com uma forma de interesse semelhante à proposta da política de segurança pública, todavia, com outros protagonistas.

\section{O Sistema de Segurança Pública no Distrito Federal}

Como consideração inicial, há a necessidade de apresentar uma pequena descrição das agências estatais responsáveis pela segurança pública no Distrito Federal para compreendermos porque foi construída esta política pública, para quais propósitos e sob influência de quais atores sociais. Nesse sentido, cabe destacar que o Distrito Federal em 
2004 estava dividido em vinte e nove Regiões Administrativas. Cada Região Administrativa tem um corpo burocrático indicado pelo governador para gerenciar e ser mais um canal de comunicação entre a comunidade local e o chefe do poder executivo da Unidade Federativa. A divisão do espaço territorial em administrações segue critério político-econômico. Assim, esse corpo burocrático do Estado é responsável por diferentes concentrações populacionais e/ou comerciais, conforme a Quadro I, que apresentava a população do Distrito Federal por Região Administrativa no ano de 2004.

\section{Quadro 1 - População do Distrito Federal em 2004}

\begin{tabular}{|l|l|}
\hline Região Administrativa & População \\
\hline Águas Claras (RA XX) & 43623 \\
\hline Brasília (RA I) & 198.906 \\
\hline Brazlândia (RA IV) & 48.958 \\
\hline Candangolândia (RA XIX) & 13.660 \\
\hline Ceilândia (RA IX) & 332.455 \\
\hline Cruzeiro (RA XI) & 40.934 \\
\hline Estrutural (RA XXV) & 14.497 \\
\hline Gama (RA II) & 112.019 \\
\hline Guará (RA X) & 112.989 \\
\hline Itapoã (RA XXVIII) & 46.252 \\
\hline Lago Norte (RA XVIII) & 23.000 \\
\hline Lago Sul (RA XVI) & 24.406 \\
\hline Núcleo Bandeirante (RA VIII) & 22.688 \\
\hline Paranoá (RA VII) & 39.630 \\
\hline Park Way (RA XXIV) & 19.252 \\
\hline Planaltina (RA VI) & 141.097 \\
\hline Recanto das Emas (RA XV) & 102.271 \\
\hline Riacho Fundo (RA XVII) & 17.386 \\
\hline Riacho Fundo II (RA XXI) & 26.093 \\
\hline Samambaia (RA XII) & 147.907 \\
\hline
\end{tabular}




\begin{tabular}{|l|l|}
\hline Santa Maria (RA XIII) & 89.721 \\
\hline São Sebastião (RA XIV) & 69.469 \\
\hline Sobradinho (RA V) & 61.290 \\
\hline Sobradinho II (RA XXVI) & 71.805 \\
\hline Sudoeste/Octogonal (RA XXII) & 46.829 \\
\hline Taguatinga (RA III) & 223.452 \\
\hline Varjão do Torto (RA XXIII) & 5.945 \\
\hline
\end{tabular}

Fonte: Seplan/Codeplan 2004

Além dos critérios sócio-políticos locais para estabelecer a divisão do espaço territorial do Distrito Federal em Regiões Administrativas, há um processo políticopartidário na Câmara Legislativa para regulamentar a convicção política dos gestores do poder executivo. Portanto, há cidades próximas com duas regiões administrativas (Sobradinho I e II) com população menor que outras regiões administrativas, como é o caso da cidade que está na Região Administrativa da Ceilândia.

Além da densidade demográfica e da divisão política representada pelo poder executivo nas administrações regionais, há também outras características sociais que devem ser consideradas e que destoam das regiões. O Índice de Desenvolvimento Humano (IDH) é um indicador que mensura três variáveis: anos de escolaridade, renda per capita e expectativa de vida. É um indicador construído que pode ser utilizado para comparar qualidade de vida entre países, entre regiões, estados e municípios. O período apresentado abaixo é o mais próximo da análise do objeto pesquisado, a partir de 2003. Em geral, analisando os dados da Secretaria de Planejamento (2003), os índices do Distrito Federal destoam quando comparados aos do Brasil. Com um IDH médio de 0,849, quando verificadas as variáveis separadamente, infere-se que a educação $(0,938)$, longevidade da população $(0,813)$ e renda per capita $(0,799)$ são discrepante quando observado a média do IDH médio brasileiro de 0,766 em 2003. Alguns serviços públicos essenciais estão distribuídos nas diversas regiões administrativas da unidade federativa quase que atingindo $100 \%$ de cobertura. O fornecimento de água potável, o tratamento do esgoto, os postos de saúde e oferta de matrícula nas escolas públicas em todas as regiões administrativas, mesmo que percebido que há uma precária prestação de serviço 
em algumas delas, fazem com que o menor índice de desenvolvimento humano da região seja maior que a média do Brasil. A Região Administrativa do Lago Sul que tinha o IDH de 0,945 em 2003, se fosse um país, teria um índice melhor que o melhor IDH do mundo, da Noruega que era de 0,942. O menor IDH no DF, da Região Administrativa de Brazlândia com 0,761, ainda é superior à média brasileira, conforme demonstra a Tabela I abaixo.

Tabela 1 Índice de Desenvolvimento Humano do Distrito Federal e de algumas RA em 2003

\begin{tabular}{|l|l|l|l|l|}
\hline $\begin{array}{l}\text { Região } \\
\text { Administrativa }\end{array}$ & $\begin{array}{l}\text { IDH - } \\
\text { Educação }\end{array}$ & IDH - Renda & $\begin{array}{l}\text { IDH - } \\
\text { Longevidade }\end{array}$ & $\begin{array}{l}\text { IDH } \\
\text { Geral }\end{array}$ \\
\hline Brasília & 0,991 & 0,948 & 0,870 & 0,936 \\
\hline Brazlândia & 0,906 & 0,642 & 0,734 & 0,761 \\
\hline Candangolândia & 0,947 & 0,761 & 0,850 & 0,853 \\
\hline Ceilândia & 0,910 & 0,670 & 0,773 & 0,784 \\
\hline Cruzeiro & 0,992 & 0,934 & 0,857 & 0,928 \\
\hline Gama & 0,942 & 0,720 & 0,784 & 0,815 \\
\hline Guará & 0,944 & 0,831 & 0,826 & 0,867 \\
\hline Lago Norte & 0,958 & 0,978 & 0,864 & 0,933 \\
\hline Lago Sul & 0,982 & 1,000 & 0,854 & 0,945 \\
\hline N. Bandeirante & 0,972 & 0,896 & 0,811 & 0,853 \\
\hline Paranoá & 0,948 & 0,612 & 0,800 & 0,785 \\
\hline Planaltina & 0,872 & 0,652 & 0,769 & 0,764 \\
\hline $\begin{array}{l}\text { Recanto das } \\
\text { Emas }\end{array}$ & 0,937 & 0,598 & 0,791 & 0,775 \\
\hline Riacho Fundo & 0,958 & 0,706 & 0,815 & 0,826 \\
\hline Samambaia & 0,921 & 0,629 & 0,791 & 0,781 \\
\hline Santa Maria & 0,934 & 0,627 & 0,820 & 0,794 \\
\hline São Sebastião & 0,944 & 0,714 & 0,804 & 0,820 \\
\hline Sobradinho & 0,923 & 0,763 & 0,824 & 0,837 \\
\hline Taguatinga & 0,944 & 0,806 & 0,816 & 0,856 \\
\hline Distrito Federal & $\mathbf{0 , 9 3 8}$ & $\mathbf{0 , 7 9 5}$ & $\mathbf{0 , 8 1 3}$ & $\mathbf{0 , 8 4 9}$ \\
\hline Fon : Sepan 2003 & & &
\end{tabular}

Fonte: Seplan, 2003

Outro ponto importante a ser destacado preliminarmente no debate sobre políticas de segurança pública diz respeito às agências de controle legalmente responsáveis pela diminuição ou controle da criminalidade que compõem o que Bourdieu (2006) chamaria de um campo social.

O que vale ressaltar neste momento é a complexidade constitutiva do campo de controle do Distrito Federal com duas polícias, sendo uma ostensiva e militar e outra investigativa e de natureza civil. Cada uma com ethos e formas de ações diferentes e que disputam, de alguma forma, poderes simbólicos no campo. 
Garland (2001) apresenta um debate similar a esta relação que mencionamos e evidencia algumas questões sobre o que ele conceituou como campo de controle do delito. A primeira questão diz respeito à complexidade do campo do controle do delito:

El campo que aquí se describe está conformado por una multiplicidad de diversas agencias, prácticas y discursos y se caracteriza por una variedad de políticas y prácticas, algunas de las cuales son bastante contradictorias entre sí. Es posible comprender su carácter general si se describe la distribución de los elementos, los principios organizadores que los relacionan y las líneas de fractura en torno a las cuales se estructuran los conflictos, en lugar de buscar identificar una esencia única común al campo en su totalidad. (Garland, 2001: 275)

Assim, na busca do mesmo objetivo, ou seja, o controle do delito, há agências que agem de forma repressiva, após a ação ilegal (a Constituição Federal, no artigo 244, determinada que esta ação, nas Unidades Federativas, sejam das Polícias Civis); e há instituições que agem antes da ação delituosa, de forma preventiva (ação de prerrogativa das Polícias Militares, segundo a Constituição Federal, no mesmo artigo).

A diversidade das instituições nesse campo torna complexa qualquer tentativa de leitura apenas por uma via, pelos possíveis valores semelhantes que há nessas instituições. Todavia, acreditamos que algumas representações sociais são comuns às várias agências de controle do delito, apesar dos interesses políticos, dos discursos e das práticas institucionalizadas serem conflitantes entre si.

A segunda questão apresentada pelo autor acerca do campo de controle do delito refere-se à necessidade de se considerar o passado das práticas, das mentalidades e das instituições. Assim:

(...) cuando se considera al campo como un todo, debemos tener en cuenta que estas prácticas y mentalidades coexisten con los residuos y continuidades de los viejos esquemas. Nuestra concentración en lo nuevo, en lo nuevo, en lo transformador, no debe hacer que pasemos por alto estas prácticas e instituciones más viejas. La historia no es la sustitución de lo viejo por lo nuevo, sino la modificación más o menos amplia de lo primero por lo segundo. El entrelazamiento entre lo establecido y lo emergente estructura el presente y nuestro análisis debe reflejar es hecho. (GARLAND, 2001: 276) 
Neste sentido, percebe-se que são raros os casos em que as instituições de controles são "fundadas" com novos paradigmas no campo de controle do delito. O caminho apontado pelo autor é a análise dos princípios organizativos, dos fundamentos estratégicos, dos valores políticos, das sensibilidades culturais e das concepções criminológicas que guiam as práticas e dão significado às instituições do campo de controle. Outro ponto de análise é como essas instituições se relacionavam anteriormente e como passaram a se relacionar às políticas públicas que podem "surgir". Como são recebidas essas possíveis mudanças pelos policiais?

A perspectiva de Pierre Bourdieu (2006) nos auxilia ao integrar a subjetividade humana às objetividades estruturais e estruturantes das instituições de controle social nesses processos de possíveis mudanças de percepção, de ações sociais e do próprio campo de controle, isto é, a percepção da relação dialética entre o habitus (o social subjetivado) e o campo social de controle (as relações sociais objetivadas), o que contribui para vislumbrar as ações dos indivíduos atrás das rígidas regras institucionalizadas (PETERS, 20:236).

Para Bourdieu (2006:61), o habitus é o conjunto das percepções e práticas de condutas que são internalizadas pelos indivíduos, mediadas pelo mundo social e pelo campo social. Como o próprio autor diz, “é um conhecimento adquirido e também um haver". Nas práticas institucionalizadas do campo de controle, o habitus é uma categoria de análise já que é o verificável, é a percepção imediata dos indivíduos sobre as políticas de controle do delito colocada em prática, pois ganha formas cotidianas.

Já o Campo social, no caso específico e como mencionado por Garland sobre o campo de controle social de controle, é uma realidade resultado das relações de força entre os indivíduos em luta no seu interior. No caso específico, o campo do controle do delito é multifacetado e em constante conflito para garantir o ethos institucional de determinada instituição e de impor sua lógica de controle, seja fazendo que o campo privilegie a ostensividade e prevenção ou a investigação e repressão ${ }^{10}$.

Apesar de figurarem como protagonistas nas ações de combate à criminalidade no Distrito Federal, a Polícia Civil e a Polícia Militar fazem parte de uma diversidade de agências de segurança pública com diferentes missões, que atuam nesse espaço geográfico e que guiaram o nosso olhar para a concepção de Castells (1999) sobre as

\footnotetext{
${ }^{10}$ Esta separação de agir legal não exclui que agências investigativas/repressivas realizem patrulhamentos ostensivos e que agências ostensivas realizem investigações ou repressões.
} 
redes interligadas em redes. Para o autor, há duas características que nos auxiliam na compreensão do desempenho desta rede e das inter-relações, das influências e entre as agências que, pelo foco da nossa análise, mas não exclusivamente, podem influenciar nas políticas públicas locais: primeira, a conectividade entre as agências, isto é, a capacidade estrutural de facilitar a comunicação sem ruído e, na segurança pública, há regulamentação que oficializa esta rede e há conectores informais que facilitam a comunicação e acelera os processos, como será descrito no capítulo três; e a segunda característica é referente à coerência, isto é, aos interesses compartilhados entre os objetivos da rede e de seus componentes (CASTELLS, 1995:232).

O sistema legal brasileiro criou agências com competências diferentes para o mesmo espaço, assim, há uma rede do Governo Federal constituída legalmente para policiar e controlar e que indiretamente pode influenciar o controle da criminalidade no Distrito Federal. Também há uma rede local com suas agências de segurança pública que tem a responsabilidade de controlar e diminuir a criminalidade neste espaço.

A Polícia Rodoviária Federal, subordinada ao Ministério da Justiça do Governo Federal, é a agência responsável por policiar as rodovias federais no Distrito Federal. Realizam Operações conjuntas com outras agências com o intuito de combater o tráfico de entorpecentes ilegais, o tráfico de seres humanos, a exploração sexual (principalmente a infanto-juvenil), entre outras ações de controle do fluxo de veículos e de pessoas ${ }^{11}$.

Já a Polícia Federal executa ações de polícia judiciária, também sob a gestão do Ministério da Justiça, sendo a responsável direta, entre outras competências, por reprimir e prevenir o tráfico ilícito de entorpecentes e outras práticas que tenham repercussão interestadual e/ou internacional e ainda necessite de uma ação uniforme ${ }^{12}$. O tráfico de drogas que cruza fronteiras, portanto, pode ser diminuído com as investigações da polícia judiciária federal e com operações da Polícia Rodoviária Federal e os pequenos comércios ilegais podem ficar sem o produto ou, no mínimo, ter dificuldade de acesso aos entorpecentes. As ações protagonizadas pelos agentes dessas agências geralmente são repressivas e, em determinados momentos, em parcerias conveniadas com outras agências estatais da unidade federativa.

As agências estatais responsáveis pela segurança pública do Distrito Federal estão sob a gestão da Secretaria de Estado da Segurança Pública. A constituição desta Secretaria

\footnotetext{
${ }^{11}$ Decreto Federal 1.655 de 3 de dezembro de 1995

${ }^{12}$ Constituição da República Federativa do Brasil, artigo 144 § 1
} 
depende do momento político-histórico, pois houve momentos em que o Departamento de Trânsito (DETRAN) foi retirado da pasta governamental e passou a integrar a Secretaria de Transporte. Outra agência que exerce atividades semelhantes ao Detran é o Departamento de Estradas e Rodagem (DER) com responsabilidade de realizar as manutenções das rodovias do Distrito Federal e de fiscalizar, inclusive crimes de trânsito, da mesma forma que o Detran. Todavia, o único que constantemente constituiu os quadros da Secretaria de Segurança Pública do Distrito Federal entre as agências com responsabilidade de manter a fluidez e segurança no trânsito é o Detran.

Entretanto, a quantidade de agentes era reduzida frente ao quantitativo de atividades que desempenha. Além de licenciar e vistoriar os veículos para circulação, fiscalizar as escolas particulares de trânsito credenciadas, entre outras atividades que estão relacionadas com a permissão de condução dos veículos realizadas nos Postos de Atendimento da agência em algumas Regiões Administrativas, há também a fiscalização nas vias públicas com a realização de operações de repressão aos crimes de trânsito. Para tais atividades, no ano de 2005 o Detran contava com o efetivo descrito no quadro abaixo que demonstra que havia um total de 729 (setecentos e vinte e nove) servidores da carreira de atividade de trânsito.

Quadro 2 Efetivo do DETRAN em 2005

\begin{tabular}{|l|l|}
\hline Categoria Funcional & Quantidade \\
\hline Auxiliares de transito & 81 \\
\hline Assistente de trânsito & 302 \\
\hline Analistas de Trânsito & 11 \\
\hline Agentes de Trânsito & 335 \\
\hline
\end{tabular}

Fonte: DODF, 2005

As atividades de controle burocrático para as permissões e as autorizações de circulação no trânsito de veículos e condutores são priorizadas frente a fiscalização e apenas 327 (trezentos e vinte e sete) servidores estavam na Diretoria de Segurança do 
Trânsito, responsável pela fiscalização e controle dos usuários das vias com 113 (cento e treze) viaturas operacionais.

Como foi mencionado, uma das agências estatais que atuam no Distrito Federal com responsabilidade de controlar a criminalidade é a Polícia Civil do Distrito Federal (PCDF). Responsável por interligar o Poder Judiciário às atividades das agências policiais formalizando ritos diários, a PCDF tem como competência constitucional exercer a função de polícia judiciária. A formação dos delegados, bacharéis em direito, auxilia na linguagem e nos ritos processuais para que essa comunicação e interligação se estabeleça. As competências dessa agência são semelhantes às da Polícia Federal, todavia, com a limitação territorial do Distrito Federal.

Assim, os policiais civis desenvolvem suas atividades com o propósito da feitura do Inquérito Policial que substancia o Inquérito Judicial. Realizam também perícias criminais e médico-legais, realizam investigações, promovem a identificação civil e criminal, colaboram com o Poder Judiciário, com o Ministério Público e demais autoridades local e federal, mantêm serviço de atendimento ao cidadão para os registros de ocorrências, realizam a custodia provisória de pessoas presas nos limites de sua competência, exercem atividades de polícia administrativa de trânsito, estabelecem o controle estatístico das incidências criminais no Distrito Federal, entre outras atividades.

Assim, há uma série de atividades burocráticas que subsidiam as atividades da própria de polícia judiciária. Para realizar essas atividades meio e fim, o quadro de servidores da PCDF tinha o seguinte efetivo em 2005 descrito no quadro abaixo.

\begin{tabular}{|} 
Quadro 3 Efetivo da PCDF em 2005 \\
\hline Categoria Funcional & Efetivo \\
\hline Delegados de Polícia & 298 \\
\hline Peritos Criminais & 190 \\
\hline Peritos Médicos legais & 71 \\
\hline Agentes de Polícia & 2.918 \\
\hline Escrivão de Polícia & 447 \\
\hline Papiloscopista & 276 \\
\hline Agentes Penitenciários & 688 \\
\hline Total & 4.888 \\
\hline
\end{tabular}

Fonte: DODF, 2005 
Estes efetivo foi distribuído em diversos Departamentos para desempenhar atividades-fim, de Polícia Judiciária, e para exercer atividades-meio, aquelas de auxílio à atividade fim. Assim, os 4.888 (quatro mil oitocentos e oitenta e oito) policiais civis (Delegados, peritos, agentes de polícia, papiloscopistas e agentes penitenciários) estavam distribuídos da seguinte forma apresentada no quadro abaixo:

\section{Quadro 4 Distribuição do efetivo da PCDF nos Departamentos}

\begin{tabular}{|l|l|}
\hline Lotação & Efetivo \\
\hline Gabinete da Chefia de Polícia & 66 \\
\hline $\begin{array}{l}\text { Departamento de Polícia } \\
\text { Circunscricional }\end{array}$ & 1.843 \\
\hline $\begin{array}{l}\text { Departamento de Polícia } \\
\text { Especializada }\end{array}$ & 701 \\
\hline $\begin{array}{l}\text { Departamento de Polícia } \\
\text { Técnica }\end{array}$ & 643 \\
\hline $\begin{array}{l}\text { Departamento de Atividades } \\
\text { Especiais }\end{array}$ & 258 \\
\hline $\begin{array}{l}\text { Departamento de } \\
\text { Administração Geral }\end{array}$ & 182 \\
\hline Corregedoria Geral de Polícia & 85 \\
\hline Academia de Polícia Civil & 42 \\
\hline Secretaria de Segurança & 878 \\
\hline $\begin{array}{l}\text { Outros afastamentos ou } \\
\text { cedidos }\end{array}$ & 199 \\
\hline
\end{tabular}

Fonte: DODF, 2005

Os departamentos de Administração Geral, a Corregedoria, a Academia de Polícia e o Departamento de Polícia Técnica são tipicamente setores que desenvolvem atividades-meio, para assegurar o controle das atividades dos policiais civis, auxiliá-los, ou contribuir na formação profissional e continuada. 
O efetivo lotado na Secretaria de Segurança incluía os policiais civis que trabalhavam na Subsecretaria do Sistema Penitenciário, pois foram cedidos agentes de polícia para auxiliar o sistema. Os 1.843 (um mil, oitocentos e quarenta e três) policiais civis lotados no Departamento de Polícia Circunscricional eram os responsáveis da instituição pelo controle do delito nas Regiões Administrativas. Geralmente, há a função do delegado-chefe da delegacia, que coordena o trabalho das diversas equipes da delegacia, e há o delegado plantonista, responsável por conduzir a abertura do inquérito policial em caso de flagrante, juntamente com o escrivão. Assim, a quantidade desses profissionais nos quadros da PCDF também limita a quantidade de delegacias nas regiões administrativas. Em 2005, por exemplo, havia cidades que não tinham delegacias e os moradores se deslocavam à cidade mais próxima para realizar os registros criminais. Da mesma forma, os policiais conduziam vítimas, autores de crimes e objetos arrolados a delegacias de outras cidades para lavrar o flagrante do ocorrido por um delegado de outra cidade. A população de Águas Claras era atendida na delegacia do setor sul de Taguatinga, por exemplo. A tabela abaixo demonstra a quantidade de delegacias por região administrativa.

Quadro 5 Distribuição do Efetivo e Viaturas do Departamento de Polícia Circunscricional em 2005

\begin{tabular}{|l|l|l|l|l|}
\hline RA & Delegacias & Postos & Efetivo & Viaturas \\
\hline Brasília & 02 & 03 & 224 & 34 \\
\hline Gama & 02 & 01 & 130 & 23 \\
\hline Taguatinga & 03 & 01 & 233 & 39 \\
\hline Brazlândia & 01 & - & 49 & 07 \\
\hline Sobradinho & 01 & - & 79 & 10 \\
\hline Planaltina & 02 & - & 120 & 22 \\
\hline Paranoá & 01 & - & 65 & 08 \\
\hline Núcleo Bandeirante & 01 & - & 64 & 13 \\
\hline Ceilândia & 04 & 01 & 273 & 43 \\
\hline Guará & 01 & - & 67 & 13 \\
\hline Cruzeiro & 01 & - & 73 & 15 \\
\hline
\end{tabular}




\begin{tabular}{|l|l|l|l|l|}
\hline Samambaia & 02 & - & 116 & 20 \\
\hline Santa Maria & 01 & - & 64 & 11 \\
\hline São Sebastião & 01 & - & 52 & 07 \\
\hline Recantos das Emas & 01 & - & 68 & 10 \\
\hline Lago Sul & 01 & 01 & 68 & 12 \\
\hline Riacho Fundo & 01 & & 53 & 12 \\
\hline Lago Norte & 01 & - & 45 & 10 \\
\hline Candangonlândia & - & - & - & - \\
\hline Aguas Claras & - & - & - & - \\
\hline Riacho Fundo II & - & - & - & - \\
\hline Sudoeste/Octogonal & - & - & - & - \\
\hline Varjão & - & - & - & - \\
\hline
\end{tabular}

Fonte: DODF, 2005

Além das delegacias circunscricionais que atuam na área da Região Administrativa, havia as ações das Delegacias Especializadas que atuavam em todo o Distrito Federal. Geralmente a grande maioria das ações dos agentes da PCDF estavam voltadas para a repressão ao crime, focadas em rondas policiais, em prisões por mandatos, em apreensão de entorpecentes e armas, em mandatos de busca e apreensão, prisões e apreensões de perpetradores dos delitos, tanto das unidades circunscricionais quanto das unidades de polícia especializada.

Assim, a quantidade e a distribuição de policiais civis não garantia que cada região administrativa tivesse os serviços por um policial da área, o que poderia ser uma variável no processo de formulação de políticas de segurança pública.

E por fim, descrevemos rapidamente a Polícia Militar do Distrito Federal (PMDF) como integrante da rede do Distrito Federal. Contrariamente à PCDF, que tem como gestores delegados que na maioria são bacharéis em direito, a PMDF tem suas origens a influência do Exército Brasileiro e uma similitude na estrutura organizacional, inclusive com alguns oficiais oriundos daquela força armada. Portanto, a estrutura organizacional, tanto a administrativa quanto a operacional (responsável por realizar o policiamento nas cidades) é semelhante. Todavia, além da estrutura, o que será demonstrado é que o habitus policial militar também sofre forte influência do Exército Brasileiro. E seria até 
interessante uma outra pesquisa sobre essa temática, pois durante o trabalho de campo vimos essa reprodução de condutas e valores em diversos setores da PCDF e do Detran local, semelhante a um processo de militarização que se revela nas práticas discursivas.

Todavia, diferentemente das outras instituições, ser militar é uma regra constitucional na PMDF e a tabela abaixo demonstra que a disposição dos cargos é uma forma de expressar a hierarquia e a disciplina com a divisão do poder de decisão, presentes nos códigos de deontologia. A tabela abaixo apresenta o efetivo da PMDF com quantitativo dos postos e graduações em 2005.

\section{Quadro 6 Efetivo da PMDF em 2005}

\begin{tabular}{|c|c|}
\hline Categoria Funcional & Efetivo \\
\hline Oficiais & 919 \\
\hline Aspirantes & 77 \\
\hline Cadetes & 77 \\
\hline Subtenentes & 135 \\
\hline Sargentos & 2.262 \\
\hline Cabos & 2.527 \\
\hline Soldados & 9.372 \\
\hline Total & 15.661 \\
\hline
\end{tabular}

Fonte: DODF, 2005

Todo o efetivo da PMDF realizava o policiamento ostensivo com o intuito de prevenir a ação criminosa e manter a ordem pública, mesmo aqueles que estivessem exercendo atividade administrativa. Mas as atividades-fim são divididas e os oficiais são os responsáveis por fiscalizar e planejar as ações policiais, enquanto os sargentos, cabos e soldados são os responsáveis por realizar o patrulhamento e as rondas ostensivas no Distrito Federal.

De forma similar às outras instituições de segurança pública, são os próprios policiais que realizam os serviços administrativos de apoio à atividade fim. $\mathrm{O}$ efetivo policial militar em 2005 estava assim distribuídos nos departamentos e unidades de apoio administrativos e de policiamento. 


\section{Quadro 7 Distribuição do Efetivo da PMDF em 2005}

\begin{tabular}{|c|c|}
\hline Unidade/Departamento & Efetivo \\
\hline $\begin{array}{c}\text { Unidades de apoio Administrativo, } \\
\text { Gestão e apoio ao Comando Geral }\end{array}$ & 2.269 \\
\hline Comandos de Policiamento & 7.211 \\
\hline Comando de Policiamento Especializado & 4.482 \\
\hline Policiais Agregados, cedidos ou em & 1.669 \\
situações diversas & \\
\hline
\end{tabular}

Fonte: DODF, 2005

As unidades de apoio administrativo, gestão e apoio ao comando são responsáveis pela formação profissional e pela formação continuada, pelo planejamento do policiamento e pelos processos de compras de recursos, por exemplo. Para realizar o policiamento ostensivo propriamente dito, a PMDF disponibilizava diretamente o efetivo de aproximadamente 11.690 (onze mil, seiscentos e noventa) policiais lotados no Comando de Policiamento e no Comando de Policiamento Especializado. São esses dois Comandos que gerenciam os Batalhões de Polícia Militar (BPM), que eram comandados por Tenente Coronéis, e as Companhias de Polícia Militar Independentes (CPMind), que eram comandadas por Majores. Tanto os BPM quanto as CPMind são chamadas de unidades policiais militares e realizam o policiamento nas regiões administrativas. Da mesma forma que o Exército Brasileiro, há um escalonamento de responsabilidade e uma divisão da gestão no território. O primeiro escalonamento está nos Comandos Regionais que são responsáveis por diversas unidades de policiamento, conforme a figura abaixo: 


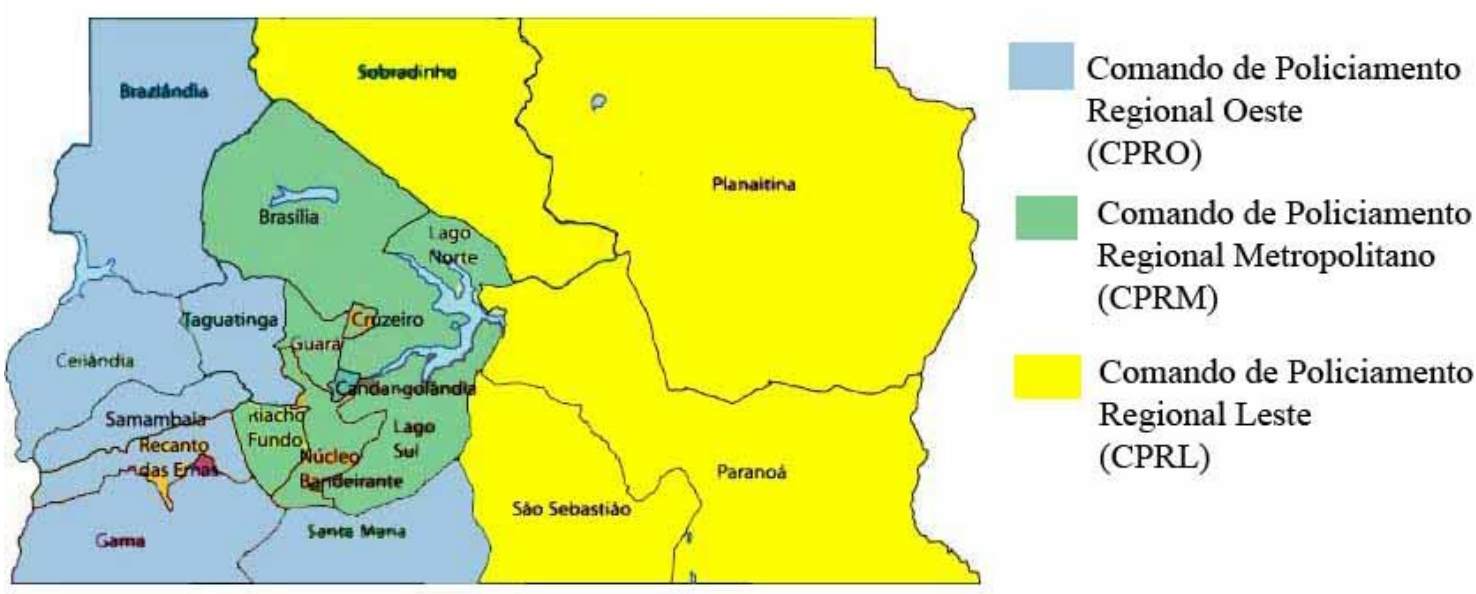

Fonte: elaborado pelo autor

Essa divisão regional fazia com que os comandantes de Comandos de Policiamento coordenassem as unidades subordinadas e se reportassem ao Comando Geral da PMDF. Assim, a lotação dos policiais militares segue uma distribuição que tem que atender a especificidade do Comando de Policiamento Regional Metropolitano (CPRM), por ser em Brasília a cidade que recebe autoridades de todo o mundo e o centro das decisões políticas do Brasil. Na tabela a seguir há a descrição do efetivo e das unidades por Região Administrativa. Os quartéis dos Comandos de Policiamento Regional também são considerados unidades de policiamento ostensivo e por isso estão relacionados como unidades de apoio ao policiamento na tabela VII 
Quadro 8 Distribuição do Efetivo da PMDF disposto em unidades de atividades fim em 2005

\begin{tabular}{|c|c|c|c|}
\hline \multicolumn{4}{|c|}{$\begin{array}{l}\text { UNIDADES OPERACIONAL COM RESPONSABILIDADE DE } \\
\text { ÁREA }\end{array}$} \\
\hline Cidade & Unidade CPR & Unidade & Efetivo \\
\hline Brasília/RA I & CPRM, & $1^{\circ} \mathrm{BPM}, 3^{\circ}$ & 1.434 \\
\hline Lago Norte/RA & CPRL, & BPM e $7^{\mathrm{a}}$ & \\
\hline XVIII & CPESP & CPMInd & \\
\hline Gama/RA II & & $9^{\circ} \mathrm{BPM}$ & 533 \\
\hline Taguatinga/RA III & CPRO & $2^{\circ} \mathrm{BPM}$ & 721 \\
\hline Brazlândia/RA IV & & $9^{\text {a }}$ CPMInd & 237 \\
\hline Sobradinho/RA V & & $13^{\circ} \mathrm{BPM}$ & 363 \\
\hline Planaltina/ RA VI & & $14^{\circ} \mathrm{BPM}$ & 449 \\
\hline Paranoá/RA VII & & $10^{\mathrm{a}}$ CPMInd & 219 \\
\hline $\begin{array}{l}\text { Núcleo } \\
\text { Bandeirante/RA VIII } \\
\text { e Candangolândia/RA } \\
\text { XIX }\end{array}$ & & $12^{\mathrm{a}}$ CPMInd & 246 \\
\hline Ceilândia/RA IX & & $8^{\circ} \mathrm{BPM}$ & 698 \\
\hline Guará/RA X & & $4^{\circ} \mathrm{BPM}$ & 444 \\
\hline Cruzeiro/RA XI & & $11^{\mathrm{a}}$ CPMInd & 172 \\
\hline Samambaia/RA XII & & $11^{\circ} \mathrm{BPM}$ & 634 \\
\hline Santa Maria/RA XIII & & $14^{\mathrm{a}}$ CPMInd & 321 \\
\hline Sebastião/RA XIV & & $17^{\mathrm{a}}$ CPMInd & 145 \\
\hline $\begin{array}{l}\text { Recanto das } \\
\text { Emas/RA XV }\end{array}$ & & $18^{\mathrm{a}}$ CPMInd & 205 \\
\hline Lago Sul/RA XVI & & $15^{\mathrm{a}}$ CPMInd & 208 \\
\hline $\begin{array}{l}\text { Riacho Fundo/RA } \\
\text { XVII }\end{array}$ & & $19^{\mathrm{a}}$ CPMInd & 182 \\
\hline
\end{tabular}

Fonte: DODF, 2005, elaborado pelo autor 
Assim, Brasília/RA I e Lago Norte/RA XVIII dispunham das unidades distribuídas na Rodoviária do Plano Piloto, no Congresso Nacional, além dos quartéis do CPRM, CPRL (Comando de Policiamento Regional Leste, responsável pelo policiamento em Sobradinho, Planaltina, Paranoá e São Sebastião), e do CPEsp (Comando de Policiamento Especializado), além das unidades responsáveis pelo policiamento ordinário. A diferença de efetivo entre as unidades responsáveis pelas Regiões Administrativas se deve, entre ouros motivos, pela densidade demográfica de cada região e por questões sócio-políticas.

Além do policiamento tido como ordinário, há o policiamento especializado, realizado pela PMDF em todo o Distrito Federal. O Comando de Policiamento Especializado era o responsável por coordenar as ações de policiamento que necessitassem de um conhecimento específico e que, somados aos quase sete mil policiais do policiamento ordinário nas cidades, disponibilizava mais de quatro mil e quatrocentos policiais militares em missões especializadas. A missão descrita abaixo para cada unidade era desenvolvida diuturnamente, todavia, os policiais realizavam o policiamento ostensivo similarmente às unidades ordinárias de cada região, todavia, havendo uma solicitação de atendimento especializado, os policiais lotados nessas unidades deslocavam-se preferencialmente para o atendimento.

\section{Quadro 9 Distribuição do Efetivo policial nas Unidades Especializadas}

\begin{tabular}{|l|l|l|}
\hline $\begin{array}{l}\text { Unidade } \\
\text { Policial }\end{array}$ & \multicolumn{1}{|c|}{ Missão } & Efetivo \\
\hline $5^{\circ} \mathrm{BPM}$ & \multicolumn{1}{|c|}{ Segurança de Embaixadas } & 330 \\
\hline $6^{\circ} \mathrm{BPM}$ & Segurança de Estabelecimentos de Ensino & 761 \\
\hline $7^{\circ} \mathrm{BPM}$ & Policiamento de Trânsito & 448 \\
\hline $12^{\circ} \mathrm{BPM}$ & Policiamento Judiciário & 418 \\
\hline $\mathrm{RPMon}$ & Policiamento Montado & 323 \\
\hline $\mathrm{BOPE}$ & Policiamento de Choque & 527 \\
\hline $\mathrm{CPRV}$ & Policiamento Rodoviário & 453 \\
\hline $\mathrm{CPMa}$ & Policiamento Florestal e de Mananciais & 284 \\
\hline $3^{\mathrm{a}} \mathrm{CPMInd}$ & Guarda do Complexo Penitenciário & 343 \\
\hline $4^{\mathrm{a}} \mathrm{CPMInd}$ & Policiamento do Congresso Nacional & 219 \\
\hline
\end{tabular}




\begin{tabular}{|l|l|c|}
\hline $16^{\mathrm{a}}$ & Policiamento Metroviário & 376 \\
CPMInd & & \\
\hline
\end{tabular}

Fonte: DODF, 2005, elaborado pelo autor

Desta, o efetivo da PMDF exercia fiscalização de trânsito em convênio com o Detran e com o DER e realizava as mesmas ações que os agentes de trânsito destas agências para controlar o fluxo de pessoas e veículos, além de atuarem nos crimes de trânsito as infrações administrativas. Também realizava o policiamento nas áreas de proteção ambiental e combatia os crimes ambientais juntamente com as agências estatais competentes do Distrito Federal e do Governo Federal. Também mantinham em 2005 uma unidade para policiar as estações do metrô, outro destacamento para policiar as áreas próximas às escolas, outro para policiar os tribunais de justiça do Distrito Federal e um grupamento especial para policiar a área externa das unidades prisionais.

Essa diversidade de ações com redes interligadas a diversas outras agências estatais e presente diuturnamente em rondas e postos em todas as áreas urbanas e rurais fazem com que o efetivo seja o maior no Sistema de Segurança Pública do Distrito Federal. Todavia, este efetivo não está à disposição para o serviço vinte e quatro horas por dia. Há, por exemplo, um doze avos deste efetivo que goza férias, outro, licenças médicas, há ainda a divisão do efetivo por turnos, sendo que há escalas de serviço no turno diurno e noturno, entre outras peculiaridades que comprometem todo o empenho do efetivo. Mesmo com essas limitações legais para disponibilizar a grande parte do efetivo policial militar para realizar o policiamento ostensivo no mesmo instante, a fração diária desse efetivo é superior ao quantitativo das outras agências da Secretaria de Segurança Pública do Distrito Federal.

A presença ostensiva diuturnamente nos espaços públicos da cidade com missões tão específicas juntamente com um contingente maior que as outras agências, distribuído em todas as regiões administrativas, colocou e coloca a Polícia Militar como principal foco das políticas de segurança pública e, portanto, quanto a isso, cabe uma breve descrição qualitativa desta instituição.

\section{Os muros da/na Polícia Militar do Distrito Federal}

Como foi antecipado ao apresentar o efetivo da PMDF anteriormente, há na gênese constitutiva da Polícia Militar traços do Exército Brasileiro presentes atualmente. 
Até 1990 o quadro de oficiais da PMDF era composto por oficiais advindos do Exército. Somente a partir do início desta década iniciou-se o processo de formação própria, pela Academia de Polícia Militar de Brasília, unidade policial militar responsável pela formação e pela formação continuada dos oficiais da instituição e, quando em convênio, por colaborar com outras polícias militares na formação de seus oficiais.

Mas as bases do militarismo, a disciplina e a hierarquia, continuam como marcos de orientação de conduta das práticas policiais, tanto nas interações entre os policiais quanto nas interações destes policiais com os cidadãos. Esses pilares estão presentes nas estruturas dos edifícios, nos regulamentos, nos uniformes, entre outros.

Os quartéis são os espaços militares destinados à gestão, ao treinamento, ao convívio dos familiares e/ou ao alojamento. O anseio pela segurança dos militares está presente no constante estado de vigilância que há nas fronteiras que dividem o espaço público do espaço do quartel. Os muros separam mais que os espaços físicos e abrigam mais que as sentinelas: são representações simbólicas que mantêm separados socialmente militares e cidadãos não policiais militares na sociedade. As entradas dos quartéis são chamadas de Portão das Armas. Há militares armados para recepcionar os visitantes e realizar a devida saudação aos policiais militares, pois há diferenças de tratamentos entre oficiais e praças.

Outra característica importante é que parte da história oficial das unidades está nas paredes da recepção. Há galeria de fotos de ex-comandantes, de melhor praça e melhor oficial policial militar do mês e do ano, galeria de policiais que morreram em serviço, entre outras informações. Em algumas unidades também há espaços separados para dormir e para uso dos sanitários. Assim, esses espaços são separados por ciclos de convivência. Há espaços para soldados e cabos, para sargentos e subtenentes, para oficiais subalternos (aspirantes e tenentes), para oficiais intermediários (capitães) e para oficiais superiores (majores, tenentes-coronéis e coronéis). Essa lógica começou a ruir somente com a entrada das mulheres nos quadros das praças e dos oficiais, porque não foram construídos espaços para oficiais e para praças femininas, portanto, mulheres praças e oficiais compartilham quase os mesmos espaços de alojamento e sanitários, por exemplo. Esta separação de ciclos e a normatização das relações estão presentes nos códigos de conduta policial militar.

Há vários códigos que regulamentam as práticas dos policiais militares. Muitos são oriundos do Exército Brasileiro, como dissemos. Há o Regulamento de Continências 
(RCONT), o Regimento Interno de Serviço Gerais (RISG), o Regulamento Disciplinar do Exército (RDE), o Estatuto da Polícia Militar do Distrito Federal, o Código de Ética Policial Militar, entre outros. Esses códigos regulamentam como deve ser o tratamento entre os militares e entre estes e seus superiores, qual uniforme deve ser usado para determinadas situações, como deve ser seu comportamento na esfera privada, entre outras normas. Segundo estudos realizados por Muniz (1999), há 125 (cento e vinte e cinco) transgressões disciplinadas no Regulamento disciplinar. Destas, a regulamentação está mais presente nas condutas que estão voltadas para a corporação, cerca de $56 \%$ das transgressões listadas foram construídas para garantir a disciplina e a hierarquia, basilares da Polícia Militar. Muniz ainda afirma que 21\% das transgressões descritas são referentes à vida social do policial.

Esta maior normatização das condutas policiais militares para garantir a hierarquia e a disciplina produz um dispositivo de punição e recompensa. É comum nas formaturas ${ }^{13}$ militares a divisão do tempo para que os oficiais dos diversos setores da gestão do quartel transmitam informações gerais à tropa de policiais militares. Há o momento para o Oficial $\mathrm{P} / 1^{14}$ (responsável pela gestão dos recursos humanos, controle das férias, escalas de serviço, entre outros), Oficial P/2 (inteligência policial militar, responsável pelo serviço de inteligência que subsidia as operações policiais), Oficial P/3 (responsável pelas instruções, cursos e pelo planejamento das operações policiais), Oficial P/4 (responsável pelas recursos materiais do quartel, inclusive viaturas, armamento, entre outros), Oficial P/5 (responsável por manter a comunicação entre a unidade policial militar e a imprensa e desenvolver atividades conhecidas no meio militar de Relações Públicas) e o Oficial SSJD, da Subseção da Justiça e Disciplina, responsável por acompanhar as sindicâncias e inquéritos policiais militares, assim como registrar os devidos elogios.

As duas notas, tanto para elogiar quanto para punir, são lidas para servir de exemplo aos demais policiais militares. Portanto, todos ficam sabendo que conduta foi punida e qual a punição, assim como qual conduta foi elogiada e, em um futuro próximo, o policial militar poderá ser reconhecido como merecedor de uma recompensa.

\footnotetext{
${ }^{13}$ Formatura é o nome dado à reunião da maioria dos militares de uma instituição, tanto para momentos comemorativos quanto para momentos informativos.

${ }^{14}$ Oficial P/1, P/2, entre outros, são os oficiais chefes de setores de gestão de unidade militar. Cada setor tem um chefe, sendo o oficial com maior patente no setor. O oficial com a maior patente é o comandante da unidade, o segundo maior é o subcomandante, o terceiro maior é o Oficial P/1, o quarto oficial com maior geralmente é o Oficial P/3, e assim sucessivamente.
} 
Este dispositivo de reconhecimento foi observado em todas as formaturas de que participei enquanto policial militar, nas várias unidades policiais militares que frequentei por estar escalado. O ritual era o mesmo. Às vezes, em estacionamentos do quartel, em ritos militares próprios, outras vezes em auditórios cedidos de outras agências estatais. $\mathrm{O}$ que mudou foi que nas últimas formaturas não era informado o nome dos policiais militares punidos, mas sempre havia a informação de que algumas atitudes dos policiais militares não condiziam com o pundonor militar e que estavam sendo observadas pelo Comando da Unidade, do Comando Regional ou pelo Comando Geral.

As punições variavam de advertência verbal, advertência escrita nos assentamentos do policial militar, repreensão, à detenção do policial militar, assim como o impeditivo subjetivo do comando pela prerrogativa administrativa que o poder discricionário lhe dá de conceder requerimentos ou não como, por exemplo, a mudança de escala, de mês de férias ou local de trabalho. As recompensas são mais subjetivas e estão interligadas à política de gestão que o comandante da unidade policial Batalhão, Companhia, Comando de Policiamento ou o Comandante Geral, adotou. Oficialmente há as dispensas de serviço que cada comandante de unidade, de comando de policiamento e do comando geral, pode dar aos subordinados. Essas dispensas legais variavam de 05 (cinco) a 30 (trinta) dias, dependendo do posto de comando.

Outra recompensa pode ser a indicação para receber medalha como um reconhecimento pelos bons serviços prestados. Alguns postos policiais como, por exemplo, de Coronel, são ocupados por policiais indicados por merecimento. Ter medalhas e elogios são fatores que auxiliam nesta indicação. As medalhas também foram dispositivos de diferenciação entre as praças (soldados, cabos, sargentos e subtenentes) porque a ascensão no ciclo de sargento se dava por pontuação e as medalhas figuravam como um dos critérios para pontuações. Ter medalha era ser reconhecido pelo comando, tanto para as praças quanto para os oficiais. Outros dispositivos de recompensas também eram utilizados como, por exemplo, melhora na escala de serviço, trabalhar com melhores equipamentos (viaturas, armamentos, rádios), gozar abono e/ou férias no mês escolhido, escolher a equipe de trabalho ou o local (posto, viatura, entre outras), entre outros.

Esse dispositivo de reconhecimento molda o comportamento do policial militar em três níveis: o elogiável (por questões de proximidade com o comando, bom trabalho administrativo ou por ser um bom policial no serviço ostensivo), o punível (por afastamento ou por discordar do comando, por desenvolver um mau trabalho 
administrativo ou por ir contra os valores da PMDF e poder, de alguma forma, desconstruir a imagem da instituição frente a sociedade civil) e os conhecidos pelos policiais militares como moitas.

Foi percebido durante o trabalho de campo que grande parte dos policiais preferem ser moitas, isto é, não assumir riscos para ser elogiado ou punido. Como há uma baixa regulação da atividade policial, sendo que a regulamentação é maior na atividade militar, há a sentença entre os policiais militares de que policial bom é o policial que chega no horário e tem o coturno engraxado. A ausência de um manual que conduza a atividade policial faz com que o policial possa assumir riscos ao mediar um conflito, ao usar a força ou a orientar um cidadão diante de uma ocorrência. Ser moita pode não dar todas as recompensas que um "bom policial” tem, mas também não lhe traz os riscos de ser indiciado em uma sindicância ou inquérito para ser punido, ou ser reconhecido como um mau policial. Mesmo que não seja punido, ser envolvido em processo disciplinar é em si mesmo pejorativo. Responder, termo utilizado pelos policiais militares quando estão sob investigação por uma conduta administrativa ou de policiamento, é termo pejorativo no meio. Independente da função, se é praça ou oficial, se é soldado ou tenente-coronel, há policiais que optam por ser moitas e aproveitar os vácuos de recompensas que os policiais militares elogiados permitem ocupar.

Desta forma, há policiais mais alinhados com o comando da unidade, da região ou com o comando geral, assim como também há oficiais policiais militares que estão dispostos a correr riscos e ser reconhecidos por aqueles que podem recompensá-los. A ascensão das praças é ato do Comandante Geral e a promoção dos oficiais, isto é, a ascensão ao cargo imediato dos oficiais, é feita por ato do Governador do Distrito Federal. A lógica do reconhecimento e de instrumentalizar a recompensa e punição é a mesma. $\mathrm{O}$ reconhecimento pelo alinhamento ou pela proximidade passa os muros dos quartéis e chega na esfera política do poder do executivo e do poder executivo local.

Enquanto a PMDF apresenta características de instituição total (Goffman, 2003), que influencia na (des)construções de identidade (Pinto, 2003), a intensidade desta influência institucional nas práticas também varia. Foi observado que em algumas unidades policiais militares há práticas "mais militares” que em outras. Unidades típicas de aquartelamento (serviços de guarda, unidades de pronto atendimento de controle de distúrbio, como o Bope e o Regimento Montado) ou com escalas de serviço com turnos de 24 horas têm práticas mais militares do que outras unidades que desenvolvem 
atividades tipicamente de policiamento. Desta forma, há unidades que primam mais pelas práticas militares do que outras, apesar de todas serem da mesma instituição e compartilharem o mesmo ethos: quanto mais as atividades são desenvolvidas fora do perímetro do quartel, menor é o grau de militarismo nas práticas e maior e o foco em atividades de policiamento. Neste processo, dependendo da unidade em que o policial militar trabalha ao longo da carreira, há a constituição de duas identidades com intensidades diferentes: a identidade policial e a identidade militar. Mesmo que ambas tenham explícitas práticas de combate ao crime e, por muitas vezes, de combate ao criminoso, a identidade militar prima por ser reconhecida pelas práticas administrativas e disciplinares, pela manutenção da moral, e um dos resultados disso é o afastamento maior em relação à sociedade civil; já a identidade policial prima pela prisão e apreensão de criminosos, apreensão de armas e entorpecentes, entre outros indicadores de combate ao crime e à criminalidade, os indivíduos com esta identidade mais sedimentada apresentaram maior possibilidade de aproximação com a sociedade civil.

A partir destas duas identidades, há um misto de autonomia policial com cadeia de comando militar, tanto para os comandantes de unidades policiais quanto para os policiais que atendem as ocorrências diariamente. Esta "liberdade de ação" é o limbo encontrado para concatenar as duas identidades que remetem a duas características tão antagônicas: autonomia de decisão para resolução de diversos problemas próprios do poder discricionário de polícia e disciplina incondicional às ordens da cadeia hierárquica. Uns têm o referencial militar para aprender como se portar e ser reconhecido. Outros aprendem com os policiais com maior tempo de serviço ou com os policiais militares com o maior número de flagrante criminais feitos.

A partir dessas pequenas considerações iniciais apresentadas, demonstrando que o campo de controle de delito é composto por várias instituições com vocações e missões diferentes que podem estabelecer conexões em diversos níveis (local, nacional e até internacional), mas que nos anos anteriores à formulação e implementação do policiamento comunitário nem todas estavam prestando serviços diretamente em todas as regiões administrativas e que a única presente diuturnamente em todas as cidades tem suas práticas nos códigos militares ou nos conhecimentos empíricos dos policiais militares, então podemos iniciar a apresentação do processo de formação da agenda sobre política de segurança pública, o processo de implementação e o estado de manutenção desta política. 


\section{CAPÍTULO 1 - AS POLÍTICAS PÚBLICAS: ATORES E FLUXOS DE CONVERGÊNCIA E AGENDA}

O estudo sobre políticas públicas foi iniciado no campo de conhecimento da Ciência Política, mas outras áreas de formulação do pensamento humano problematizam esse tema. A multiplicidade de áreas de conhecimento com interesse nesse objeto se dá pelo alcance que as Políticas Públicas atingem na sociedade, como por exemplo, o papel do Estado, as articulações e impactos na sociedade civil, os grupos que se formam e se articulam, os processos "racionais" de construção e implementação das políticas públicas, questões econômicas e políticas, possíveis mudanças culturais nas instituições, entre outros.

Assim, a definição do termo Política Pública é complexa por englobar várias Ciências. Inicialmente, destacamos que o termo público restringe as ações à área de domínio público como, por exemplo, o setor público, a opinião pública, a saúde pública, a educação pública, a segurança pública entre outros (DIAS \& MATOS, 2012). Dessa forma, o termo exclui a esfera privada ou de competência privada. Portanto, entendemos que a primeira característica do termo "público" ou que está na esfera pública é parte endógena, constituinte e constitutiva, do conceito política pública.

Todavia, compreendemos que a definição de esfera pública e esfera privada demanda um debate contextualizado no tempo e no espaço. Educação dos filhos e das filhas, constituição da família, sexualidade, domínio sobre o próprio corpo, direito à morte, entre outros assuntos, são alguns debates em que não há consenso universal se pertence a esfera pública ou a esfera privada. Assim, a esfera pública pode estar presenta no espaço micro ou no espaço macro, mas principalmente há a compreensão local sobre o que é de interesse público.

O Estado é a principal força administrativa que detém e gerencia os recursos necessários para oferecer à sociedade civil ordem e segurança por um longo período. Além dos recursos, o Estado detém o monopólio do controle legislativo na esfera pública e a utilização da força como coerção. Também é quem gerencia recursos para atender demandas sociais percebidos por diversos grupos na sociedade.

Apesar de o Estado ser o maior formulador de políticas públicas, pela quantidade de recursos que gerencia e pela possibilidade de implementar políticas por um longo 
espaço de tempo, há empresas e as Organizações Não-Governamentais (ONGs) que podem construir ações para resolver demandas de interesse público sobre algo público.

Assim, mesmo tendo uma percepção holística, a preeminência da ação estatal no processo de formulação e implementação é dissonante quando comparada às ações de ONG's, empresas e outros atores. Além de quem detém o poder de formular e implementar a política pública serem variáveis de análise, o Banco Interamericano de Desenvolvimento (BID, 2007:17) identifica algumas características das políticas públicas relevantes no processo de análise:

- Estabilidade: a estabilidade da política pública no tempo;

- Adaptabilidade: a possibilidade de ajuste da política pública ser ajustada quando há alteração no cenário em que foi planejada (questões econômicas, sociais, culturais, políticas) que podem influenciar nas metas estabelecidas;

- Coerência e coordenação: diz respeito à compatibilidade com outras políticas públicas;

- Qualidade da implementação e da aplicação efetiva: a qualidade do corpo técnico é essencial neste processo;

- Consideração do interesse público; e

- Eficiência.

Este conjunto de características auxilia entender o porquê de uma política pública ser eficiente. Ao analisá-los, podemos perceber porque consegue atingir as metas estabelecidas e perdurar, seja pelos arranjos político-econômico-sociais, que podem influenciar alterações na implementação ou na execução da política, seja nos processos de manutenção para que perdurem no tempo e no espaço. Em outras palavras a governabilidade estabelecida sobre o objeto e sobre a política pública estabelecida.

Para que uma política de governo se converta em política pública, é necessário que esta se baseie em programas concretos, critérios, linhas de ação e normas; planos, previsões orçamentárias, humanas e materiais; também podem ser incluídas aí as disposições constitucionais, as leis e os regulamentos, os decretos e resoluções administrativas, dentre outros. (DIAS \& MATOS, 2013:16)

Outra característica importante elencada por Dias e Matos (2013) é quanto ao nível da política pública e suas competências nas esferas de governo. Sendo as políticas públicas meios para alcançar determinados fins e metas, os autores identificam no Brasil três níveis distintos de políticas governamentais associadas a três níveis de competência 
da República Federativa do Brasil: da União, do Estado e dos Municípios. Nesse sentido, a União ficaria responsável pelas políticas públicas macro, podendo ser indutora das políticas públicas de Estados e Municípios. Todavia, não é somente a União que atua no ciclo da política pública, isto é, na agenda, na formulação, na implementação e na avaliação. Há outros atores que participam desse processo, atores formais e informais, individuais ou coletivos, governamentais e não-governamentais.

Segundo Giuliani (2005), nos vários níveis de políticas públicas (macro, intermediário e operacional), há entendimento diferente dos problemas e das soluções, assim como também são os interesses e os atores e que a análise das políticas é mais complexa nos níveis estratégico-estruturais, sendo mais fácil mapear atores, interesses, estilos e culturas, razões de sucesso ou insucesso de uma política pública de nível operacional do que uma política pública macro ou nível estratégico.

Inicialmente, ao analisar as políticas públicas, utilizamos as categorizações de Moon e Ingraham (1998) para compreender a participação de atores. Para os autores, há dois grupos de atores que estão relacionados com a política pública:

\section{A) Atores governamentais:}

Neste grande grupo há os atores políticos que são os indivíduos investidos de cargos do poder Executivo ou legislativo e possuem legitimidade para propor políticas públicas, pois são representantes de interesses da coletividades na democracia brasileira, em nome de seus representados; além dessa representação, são portadores de autoridade de tomada de decisão e fiscalização, mesmo que temporária. Outra função do político, segundo os autores, seria a de identificar os problemas públicos e decidir quais ações são mais adequadas como resolução.

Esses atores, como representantes legítimos de grupos e, portanto, de interesses, têm acesso privilegiado a diversos recursos próprios do Estado. Os políticos do poder executivo são responsáveis pela administração burocrática do governo de forma direta ou indireta. Os políticos do poder legislativo influenciam e aprovam o orçamento e controlam a execução orçamentária do poder Executivo. Além do mais, os atores políticos também são formadores de opiniões e podem construir consensos para possíveis soluções para problemas públicos.

Outro ator importante na arena são os designados politicamente. Essas são as pessoas que ocupam cargos públicos indicados por políticos eleitos e em funções de 
chefia, direção e assessoramento na administração pública. Os designados podem ser investidos de funções de confiança ou investidos de cargo comissionado. A função de confiança pode ser percebida como uma promoção política temporária ao servidor público de carreira, sendo recompensada com gratificações salariais.

Já os cargos comissionados são acessíveis aos servidores públicos e aos nãoservidores públicos. São os secretários de Estado, por exemplo, que são indicados pelo ator Político. Esses cargos servem, geralmente, como moedas de troca que podem ser oferecidas aos correligionários que colaboraram na candidatura. Segundo Secchi (2013), as legendas vencedoras tentam equilibrar as indicações entre indicações com caráter técnico e indicações de caráter político entre os escalões de governo. Se no processo de escolha não houver esse equilíbrio, Secchi diz que o governo pode não conseguir o apoio político se os comissionados forem puramente técnicos, ou arriscar que a máquina política tenha incapacidade técnica se a escolha for puramente política.

Por último, como ator governamental, há os burocratas que mantêm a administração pública ativa, sem que os ciclos eleitorais afetem esse processo. Secchi destaca aqui a percepção de Max Weber acerca do modelo burocrático perfeito, que põe em relevo como princípio a impessoalidade e a legalidade, marcas das ações cotidianas.

Todavia, além desses princípios do modelo weberiano, Secchi (2013 e 2009) apresenta o modelo gerencial, que vislumbra a discricionariedade do burocrata que pode influenciar a eficiência e eficácia das políticas públicas. Segundo o autor, os burocratas influenciam em todas as fases do ciclo de política pública: na formação da agenda, no auxílio da seleção dos problemas "relevantes", na formulação de alternativas, na implementação e na avaliação das políticas públicas.

Segundo Downs (1967), citado por Secchi (2013:106), os burocratas podem ser:

a) Alpinistas: são pragmáticos, focados em suas carreiras e que têm metas para progredir na hierarquia governamental;

b) Conservadores: resistentes às mudanças e defensores ferrenhos do status quo;

c) Devotos: burocratas fiéis a uma convicção política ou valor de fundo das políticas públicas como, por exemplo, em sistema de transporte público e pelo automóvel não poluente;

d) Defensores: são os burocratas fiéis às agências ou à instituição;

e) Homens de Estado: são os burocratas leais à sociedade e ao interesse público. 
Já Lipsky (1980), também lido por Secchi (2013), contribui para a análise ao vislumbrar o Burocrata de Linha de Frente como ator governamental que tem contato com o público e que apresenta o maior grau de discricionariedade, maior poder de decisão como, por exemplo, policiais, professores, entre outros.

\section{B) Atores não-governamentais:}

Fora da administração pública, esses atores também podem influenciar o ciclo das políticas públicas. Entre eles estão os Grupos de Interesse ou Grupos de Pressão. Esses grupos podem ser formalmente constituídos como, por exemplo, associações comerciais, sindicatos, movimentos sociais, entre outros. Os grupos de interesse podem participar do ciclo da política pública auxiliando revelar ou escamotear um problema, pois têm diversos recursos para pressionar por determinadas políticas: os recursos financeiros, cognitivos e os organizacionais.

O recurso cognitivo chama atenção porque há problemas que necessitam de conhecimento específico para constituir soluções, como, por exemplo, o conhecimento acadêmico sobre políticas de saúde, segurança e educação públicas. Já os recursos organizacionais demonstram a capacidade do grupo em planejar e articular sobre determinado objeto.

Segundo Secchi (2013:110), os grupos de interesse podem, além de influenciar o reconhecimento ou encobrimento de problemas públicos, pressionar de forma direta ou indireta os tomadores de decisão e a implementação das políticas públicas, principalmente utilizando de campanhas publicitárias, financiamento de campanhas eleitorais, marchas ou paradas, greves. Ainda segundo o autor, o simples fato de existirem os grupos de pressão já há uma influência no desenho das políticas públicas.

O segundo ator não-governamental é o Partido Político. Esses grupos formalizados podem influenciar as decisões governamentais diretamente, sendo aliados ou parte da oposição. Durante as eleições, eles podem entrar em conflito por áreas temáticas na formação das legendas e podem captar demandas da sociedade civil.

Há duas interpretações das articulações políticas dos partidos: a primeira entende que as ações políticas dos partidos políticos são proativas, pois socializam valores políticos e percepções sobre a esfera pública buscando uma construção de consensos; a segunda percebe que as articulações são promovidas por agentes com interesses, lutando 
para que as demandas sociais de determinados grupos sejam atendidas nas políticas governamentais. Para tanto, os partidos recrutam e preparam políticos para serem governantes; estando no governo, estes controlam a atuação governamental, fiscalizam a atuação governamental, coordenam a atuação parlamentar, assim como influenciam a votação, e podem ainda formular e avaliar políticas públicas (SECCHI, 2013). Entretanto, há o entendimento para este trabalho que os partidos políticos podem ser pro e reativos, dependendo do quanto o partido pretende flexibilizar os seus valores orientadores para acolher determinadas alternativas como proposta de governo.

Além dos Partidos Políticos, outro ator político não-governamental importante na análise das políticas públicas é a Mídia, principalmente por ter a possibilidade de difundir informações formuladas por jornalismo investigativo, por análise de especialistas, entre outras fontes. Como consequência do ato de informar, a mídia também realiza um controle social sobre a esfera política.

Todavia, quem possui a concessão dos meios de comunicação também tem interesses e visões de mundo (SECCHI, 2013:112). Assim, os diversos meios de comunicação como, por exemplo, a mídia impressa, televisiva, radiofônica e de internet, podem influenciar os processos de construção da agenda e de avaliação das políticas públicas.

Influenciam processo de construção da agenda porque podem evidenciar e chamar atenção para problemas que não estavam em debate público. Assim, atores governamentais e não-governamentais estão atentos à agenda da mídia para se prepararem para debater e construir as próprias agendas.

Da mesma forma, a comunicação de determinado problema pode ser negligenciada ou ignorada por diversos motivos, entre eles, o interesse do detentor do meio de comunicação, a incapacidade dos jornalistas para debater o tema, pela baixa expectativa de audiência em relação ao tema, entre outros motivos.

As organizações de pesquisas e os conselheiros em políticas públicas também são atores não-governamentais que influenciam o ciclo da política pública. Também compõem este grupo os institutos de pesquisas e de políticas públicas e atuam na disseminação do conhecimento próprio para formular e avaliar políticas públicas.

Para Soares (2009), o Instituto de Pesquisa Econômica Aplica (IPEA), o Departamento Intersindical de Estatística e Estudos Socioecnômicos (DIEESE), o Instituto de Estudos do Trabalho e Sociedade (IETS), o Centro Brasileiros de Relações 
Internacionais (CEBRI) são alguns exemplos de Conselheiros em política públicas. Colaboramos com um adendo ao afirmar que os Núcleos de Pesquisas das Universidade e Centro Acadêmicos, assim, como o Fórum Brasileiro de Segurança Pública, fomentam o debate e o resultados de suas pesquisas podem, de forma direta ou indireta, colaborar para a agenda, formulação ou avaliação de políticas públicas.

Por último, os destinatários das políticas públicas também são percebidos como atores não-governamentais que podem influenciar o ciclo de políticas públicas. Segundo Secchi (2013), esses atores têm participação passiva, mas podem assumir em determinados momentos participação ativa como, por exemplo, em conselhos. Assim, da mesma forma que os executores da política pública são destinatários, os beneficiários da política também podem ser considerados como um indivíduo que exige tal participação na política pública.

Estes atores governamentais e não-governamentais atuam na esfera política com estratégias, recursos, intensidades e motivações diferentes e em diferentes partes do clico da política pública, isto é, atuam de forma diferente na formação da agenda, no auxílio da seleção dos problemas "relevantes", na formulação de alternativas, na implementação e na avaliação das políticas públicas.

\subsection{O Processo de Agenda e Formulação de Políticas Públicas}

O processo de construção da agenda de segurança pública e da formulação da política inicia-se bem antes da implementação, em 2007. Assim, da mesma forma que foram apresentados os dados relativos ao sistema de segurança pública do Distrito federal em 2005, a apresentação deste processo inicia-se com a análise de dados anteriores a esse ano para reconstruir a narrativa dos entrevistados e dos documentos analisados.

Atualmente, a sensação de segurança fomenta grandes debates nas esferas política e acadêmica. Segundo Castel (2005), a insegurança moderna não tem origem na falta de proteção. Mas, segundo o autor, o fato de ser protegido é viver cercado de sistemas de segurança que são construções complexas e frágeis que trazem em si mesmas o risco de falhar em sua tarefa e de decepcionar as expectativas que elas suscitam (Castel, 2005:8).

A primeira conclusão do autor é que a busca pela proteção traz insegurança. Ser protegido é ser ameaçado pela falha dos sistemas apresentados pelo Estado para controlar 
a criminalidade. Para o autor, as sociedades modernas estão centradas no indivíduo, promovendo-lhe vulnerabilidade. O sentimento de insegurança é o desnível entre uma expectativa socialmente construída de proteção centralizada no Estado e a capacidade efetiva de uma determinada sociedade em colocá-la em prática.

Aliás, como demonstram alguns pesquisadores (Rosenbaum, 2002; Bayley,2006), a percepção de insegurança e o medo que a população tem são alguns dos fatores que podem estimular a mudança de práticas cotidianas e fomentar o debate para implementar políticas públicas em uma determinada região.

Para compreender quais são os outros fatores, sem desprezar a percepção da insegurança e do medo, recorremos ao modelo de análise teórico dos Múltiplos fluxos (Multiple Streams) de Kingdon (2003).

Segundo Capella (2006), este modelo possibilita compreender o processo de formulação da agenda de políticas públicas (agenda-setting) privilegiando como uma determinada questão se torna importante em um determinado momento, chamando a atenção do governo e passando a integrar a agenda para a implantação das ações que estão estabelecidas na política pública.

O modelo permite considerar a política pública como um conjunto de quatro fases distintas: a) o estabelecimento de uma agenda de política pública; b) o conjunto de alternativas para a questão definida como importante a ser solucionada; c) a escolha da alternativa dominante; e d) a implantação da política. O modelo de múltiplos fluxos tornase referência para esta pesquisa porque pontua os dois estágios iniciais pré-decisórios da política pública: a formação da agenda (agenda setting) e as alternativas para a formulação das políticas (policy formulation).

Em qualquer governo há várias questões que disputam atenção dos tomadores de decisões para entrar na agenda governamental. A agenda governamental é o conjunto de assuntos dos quais governo e pessoas ligadas às temáticas concentram tempo e esforços por um determinado momento (Kingdon, 2003:13).

O pronto atendimento nos hospitais, a taxa de analfabetismo, a manutenção da empregabilidade da população economicamente ativa, a mobilidade urbana, a revitalização de espaços urbanos, o controle da taxa de inflação, a inserção das minorias em espaços segregadores, o lazer para jovens e idosos, a escassez e/ou a contaminação de recursos naturais que podem diminuir o acesso à agua diariamente, o acesso às manifestações culturais diversas (teatro, cinema, espetáculos circenses) e a diminuição de 
crimes hediondos ou cometidos por adolescentes são algumas questões, entre outras, que disputam a atenção das autoridades. Todas são questões socialmente percebidas que não, necessariamente, serão elencadas como prioritárias para resoluções.

Há um subconjunto de questões que formam as agendas especializadas. Essas são assuntos típicos de formuladores setoriais de políticas públicas, mas que, assim como as outras, aguardam decisões governamentais. Cabe salientar que, segundo Baumgartner \& Jones (1993:25), para instrumentalizar a análise e colaborando com o modelo de Kingdon, há uma “imagem” (policy image) construída da política que estrutura os arranjos institucionais entre os membros que disseminam questões e, em alguns casos, há grupos que detêm o monopólio da imagem da política. Assim, agendas especializadas tendem a ter a imagem monopolizada por especialistas.

Diante do grande volume de questões que estão "em concorrência" por espaço político decisional, apenas as que despertam interesses são realmente consideradas e passam a compor a agenda decisional, que é um conjunto de questões que aguardam decisões dos formuladores de políticas (policies).

Segundo o modelo teórico, uma questão passa a integrar a agenda decisional ou há a mudança de agenda quando há a convergência entre os três fluxos: problemas (problems), soluções ou alternativas (policies) e política (politics) que serão apresentadas nas próximas seções com a descrição da análise dos dados anteriores à formação da agenda de políticas de segurança pública e que se mantiveram por um determinado período.

\subsubsection{Fluxo Político}

Neste fluxo há a participação predominantemente ativa dos atores políticos. Aqui, há a necessidade da barganha e da negociação política para a construção do consenso. Para tanto, dependendo do que Kingdon chama de "humor" ou clima, o fluxo depende da força política organizada e da mudança de funcionários em posições estratégias dentro do governo.

Todavia, no Distrito Federal, até então, o debate político estava em torno da polarização entre o Partido dos Trabalhadores (PT) e os Rorizistas. Joaquim Domingos 
Roriz era um político tradicional e vencedor nas urnas. Foi nomeado governador do Distrito Federal em 1988 por dois anos e em 1990 foi eleito governador por quatro anos. Foi sucedido pelo então desconhecido professor Cristóvam Buarque, filiado ao PT, Roriz não pôde participar porque não havia o expediente da reeleição para governador instituído ainda. Nos pleitos seguintes, já com a possibilidade de reeleição constituída, Joaquim Roriz participa e vence duas eleições, governando de janeiro de 1999 a 2006.

O espaço político local estava marcado por dois lados que, de um lado havia o discurso pela tradição e, de outro, a oposição com um viés de representação dos trabalhadores, apresentando, por isso, uma postura de fiscalização e de denúncias das práticas consideradas erradas dos gestores da situação. Construir consenso na Câmara Legislativa para o debate sobre determinadas temáticas era difícil.

Os debates e sugestões de projetos de lei na Câmara Legislativa não privilegiaram a temática da segurança pública. Apenas para pontuar, destacamos dois representantes de partidos que desenvolveram atividades partidárias que se destacaram pela autoafirmação de oposição um ao outro, um por ser representante filiado ao Partido dos Trabalhadores (PT) e outro representante filiado ao Partido dos Democratas (DEM, então Partido da Frente Liberal, PFL), então apoiador de Joaquim Roriz. Sidiney da Silva Patrício, filiado ao Partido dos Trabalhadores (PT), ex-cabo da PMDF, foi expulso da instituição por conduzir movimento grevista na década de 90, eleito deputado distrital em 2006 com 18.889 votos (TSE, 2014) e presidiu a Comissão de Segurança da Câmara Legislativa, articulou politicamente a área da segurança pública na Câmara Legislativa. Segundo o deputado, “...segurança pública não se resolve apenas com polícia” (CL, 2007). Nas eleição para o sufrágio de 2010, ele contribuiu na construção das proposta de eleição na campanha da coligação do Partido dos Trabalhadores, sendo reeleito com 22.206 (vinte e dois mil duzentos e seis) votos em 2010 (TSE, 2014).

Já no então Partido da Frente Liberal (PFL) que passou a ser Partido dos Democratas (DEM), o Coronel da reserva da PMDF, João Alberto Fraga Silva, elegeu-se deputado federal em 2002 com 27.939 (vinte e sete mil, novecentos e trinta e nove) votos. Em 2006 foi reeleito com 95.514 (noventa e cinco mil, quinhentos e quatorze) votos. No pleito de 2010 tentou ser Senador da República, sem sucesso, mas com uma expressiva votação de 511.517 (quinhentos e onze mil quinhentos e dezessete) votos.

Além dessas duas personagens políticas, houve e há vários outros que figuram no cenário político que representam as categorias (tanto da Polícia Militar, quanto da Polícia 
Civil e do Corpo de Bombeiros Militar) e que trazem consigo, ao apresentarem as propostas ao executivo, possíveis votos na Câmara Legislativa para outras temáticas de interesses do Governador, além da possibilidade de liderar partes das categorias representadas.

Todavia, essa legitimidade dada pelos eleitores não resultou em proposições na Câmara Legislativa ou em políticas de segurança em seus mandatos. Sem um político com capital político dedicado a promover o debate representativo de categorias profissionais, por exemplo, houve pouquíssimas propostas que envolvessem a Segurança Pública ou algumas das agências de segurança pública. Das 601 (seiscentas e uma) proposições projeto de lei no ano de 2005, apenas 03 (três) eram referentes a alguma das agências de segurança pública.

Uma das proposições, da Deputada Eliana Pedrosa, pretendia regulamentar o acesso e o transporte gratuito dos policiais e bombeiros militares no Distrito Federal nos Veículos Públicos Coletivos; outra proposta, do Deputado Chico Floresta, proibiria policiamento com armas e cães durante as manifestações no Distrito Federal; e a terceira proposta, do Deputado Gim Argelo, criaria a Guarda Metropolitana de Segurança Escolar. Todas essas propostas são pontuais, não auxiliaram para fomentar um debate político para que atores políticos iniciassem um empreendimento de constituir uma agenda sobre segurança pública, e todas elas foram arquivadas pela Câmara Legislativa.

Além dos conflitos polarizados entre rorizistas e petistas e seus apoiadores, e da falta de políticos engajados com a questão da segurança pública, a agenda da mídia local misturava-se com a agenda da Capital Federal. A questão política nacional ocupava o noticiário local por não deixar de ser também uma notícia relevante pelo local em que aconteciam os conflitos políticos e os envolvimentos dos atores políticos que circulavam pela cidade.

Um fato político com grande repercussão nacional começou ser revelado no começo do ano de 2005: a gravação do recebimento de propina por políticos da base aliada do Governo Federal para votar a favor das propostas governamentais. O esquema de corrupção conhecido como Mensalão ganha as capas de jornais e ocupa boa parte da atenção midiática para os desdobramentos políticos e judiciais.

Outro fato político que mobiliza os políticos tem tempo para acontecer e não precisa de outros atores para iniciar a discussão, trata-se das eleições locais. No caso específico, a formação da legenda, os acordos prévios de distribuições de cargos e pastas 
de governos na futura gestão criam um ambiente de harmonia entre os políticos aliados para criarem proposições sobre a temática que pretendem influenciar no próximo governo.

Em 2006, três frentes se formaram para disputar as eleições: os grupos tradicionais polarizados eram representados pelo candidatura de Arlete Sampaio para governadora, representando a legenda liderada pelo Partido dos Trabalhadores e a legenda encabeçada por Maria de Lourdes Abadia com apoio de Joaquim Roriz. Todavia, um terceiro ator político surge para a disputa, José Roberto Arruda, ex-aliado de Roriz e que, além de disputar o capital político com o antigo grupo de aliados também disputa dentro do próprio partido, com Paulo Octavio, para ver quem seria o candidato a Governador do Distrito Federal.

Além desse cenário político e da atenção dos atores no último ano apenas para a eleição no Distrito Federal, há outros fatores que podem mobilizar os atores políticos além dos conflitos partidários: as denúncias de má gestão, as eleições e a busca do alinhamento do fluxo político com o fluxo dos problemas e o fluxo das soluções.

\subsubsection{Fluxo do Problema}

Para Kingdon (2003), o modelo teórico analisa como uma questão torna-se um problema, isto é, analisa como as questões são reconhecidas e ocupam a agenda governamental. Capella (2006) destaca que o modelo de Kingdon enumera três formas para uma questão ser reconhecida como problema: a) Indicadores (auxiliam, mas não determinam o reconhecimento); b) eventos, crises e símbolos; e c) feedback das ações governamentais.

Neste fluxo destaca-se a força construtiva que o reconhecimento de um assunto pode contribuir para que a temática receba a atenção dos gestores e da sociedade civil para o formação da agenda governamental de política pública e, posteriormente, da política pública. Na questão da segurança pública, todavia, há que se destacar que sensação de segurança pode não estar associada à não ocorrência de crime ou delito na região. Há outros construtos sociais que estabelecem o que é um lugar ou momento seguro que podem influenciar a sensação de (in)segurança e, portanto, influenciar o momento 
que a temática ganha atenção para ser percebida como relevante e entrar na agenda de política pública governamental.

Neste sentido, a sensação de segurança tem relação com o tempo e com o espaço, assim como a percepção da violência e da sua intensidade e presença na vida cotidiana. Em outras palavras, a percepção do que é violência e sua "tolerância" altera no espaço e no tempo, assim como a percepção da proximidade desta violência causadora da sensação de insegurança.

A normatização e regulação das condutas mudam, assim como novas modalidades de crimes e "novos crimes surgem" e entram nas estatísticas, podendo influenciar na sensação de segurança e na sensação da proximidade da violência. Outros crimes “desaparecem" e não são mais percebidas como ameaças à sociedade, aos cidadãos e não influenciam a sensação de segurança. Dito isto, podemos destacar os principais indicadores que poderiam influenciar na sensação da segurança a partir de 2004 no Distrito Federal, principalmente os mais violentos como, por exemplo, homicídio. ${ }^{15}$

Primeiramente, da mesma forma que as Regiões Administrativas são diferentes entre si, com indicadores sócios-econômicos e disponibilidade de recursos públicos, a distribuição dos registros das ocorrências também é desigual. O processo de ocupação espacial do Distrito Federal demonstra estas diferenças tanto de qualidade de vida quanto de distribuição de registros de ocorrências de crimes, especificamente os crimes violentos.

Se a qualidade de vida expressa no Índice de Desenvolvimento Humano supera a média do Brasil, o mesmo pode ser dito sobre os índices de mortalidade. Como demonstram os dados de Vasconcelos e Costa (2005), o Distrito Federal apresenta uma taxa de homicídios superior à média nacional, conforme gráfico abaixo construídos pelos autores

\footnotetext{
${ }^{15}$ A Subnotificação de vários crimes e os diferentes níveis de qualidade de produção dos dados estatístico não permitem mensurar e comparar dados estatísticos entre unidades da federação com absoluta certeza da quantidade de ocorrências registradas e a quantidade de crimes reais. Todavia, a taxa de mortalidade por homicídio é um indicativo que diminui a taxa de subnotificação principalmente pela constituição do próprio crime.
} 
Gráfico 1 - Taxas de mortalidade por homicídio. Brasil e Distrito Federal 1980-2000

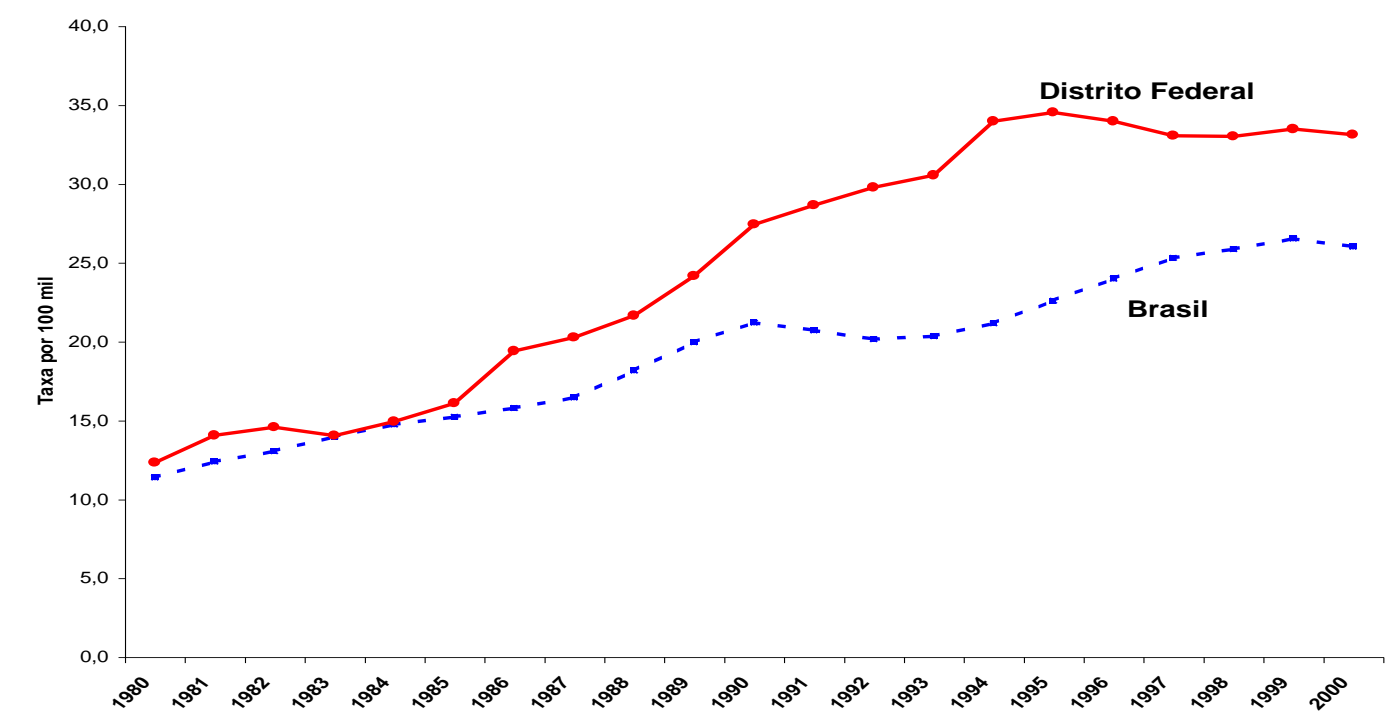

Fonte: VASCONCELOS e COSTA, 2005

Mesmo seguindo a tendência de crescimento nacional, as taxas do Distrito Federal se mantiveram acima da média nacional nas duas últimas décadas do século XX. Como destacaram os autores (Vasconcelos e Costa, 2005), o crescimento da taxa foi de 12,3 óbitos por 100 mil homicídios para 33,3 no ano de 2000. Quando comparado com outras capitais do Brasil, há também o destaque da capital federal quando observado que tal índice de criminalidade demonstrada na figura abaixo que a taxa de Brasília coloca a cidade em uma posição mediana em relação às outras capitais, 
Gráfico 2 - Taxas de Mortalidade por homicídio

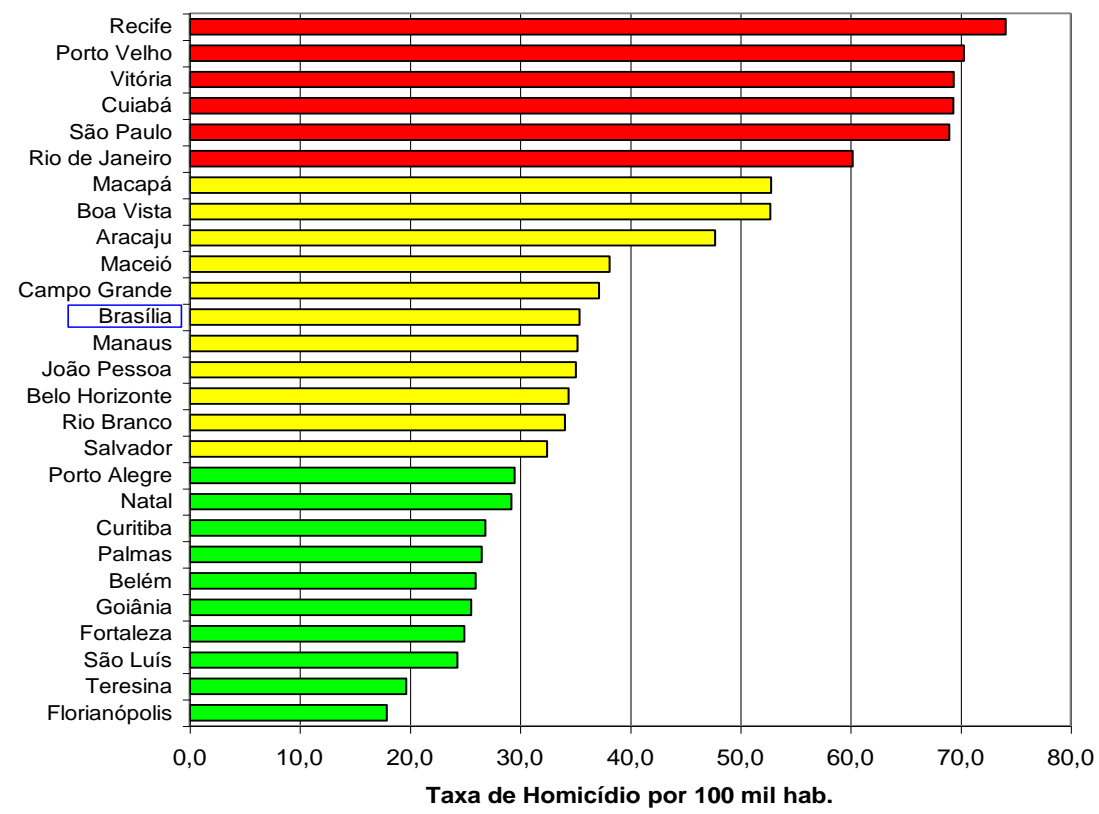

Fonte: VASCONCELOS e COSTA, 2005

Todavia, da mesma forma que o Índice de Desenvolvimento Humano do Distrito Federal é o maior do Brasil, há, uma discrepância da qualidade de vida entre as Regiões Administrativas, bem como, uma distribuição desigual das ocorrências e dos registros dos crimes violentos na unidade federativa. Enquanto há várias ocorrências que se destacam em números absolutos em algumas cidades, como, por exemplo, em Ceilândia, no Gama, no Itapoã, no Paranoá, em Planaltina, no Recanto das Emas, entre outras cidades que têm grande quantidade de registros em relação às outras Regiões Administrativas que, em determinados anos, não houve registro de homicídio como, por exemplo, Lago Sul e Lago Norte, Núcleo Bandeirante, Jardim Botânico, Sudoeste/Octogonal, entre outras cidades que teve baixo registro de homicídio. 
Quadro 10 Número de Homicídios nas Regiões Administrativas do DF entre 2004 e 2007 Quadro 11 Número de Homicídios nas Regiões Administrativas do DF entre 2004 e 2007

\begin{tabular}{|l|l|l|l|l|}
\hline Região & 2004 & 2005 & 2006 & 2007 \\
\hline Administrativa & & & & \\
\hline Brasília Claras & 11 & 03 & 13 & 12 \\
\hline Brazlândia & 23 & 18 & 24 & 20 \\
\hline Candangolândia & 12 & 11 & 14 & 19 \\
\hline Ceilândia & 75 & 00 & 02 & 03 \\
\hline Cruzeiro & 04 & 01 & 02 & 03 \\
\hline Estrutural & 24 & 26 & 23 & 30 \\
\hline Gama & 35 & 31 & 29 & 40 \\
\hline Guará & 08 & 09 & 09 & 09 \\
\hline Itapoã & 27 & 12 & 20 & 17 \\
\hline Jardim Botânico & 01 & 01 & 02 & 00 \\
\hline Lago Norte & 02 & 00 & 03 & 00 \\
\hline Lago Sul & 02 & 00 & 01 & 03 \\
\hline Núcleo Bandeirante & 03 & 03 & 02 & 00 \\
\hline Paranoá & 30 & 31 & 24 & 21 \\
\hline Park Way & 03 & 02 & 01 & 02 \\
\hline Planaltina & 62 & 61 & 65 & 44 \\
\hline Recanto das Emas & 35 & 42 & 29 & 46 \\
\hline Riacho Fundo I & 00 & 06 & 06 & 07 \\
\hline Riacho Fundo II & 06 & 01 & 04 & 06 \\
\hline Samambaia & 54 & 41 & 33 & 52 \\
\hline Santa Maria & 39 & 33 & 33 & 45 \\
\hline São Sebastião & 16 & 18 & 27 & 26 \\
\hline SIA & 00 & 03 & 01 & 00 \\
\hline Sobradinho I & 14 & 14 & 12 \\
\hline Sobradinho II & 01 & 00 & 00 \\
\hline Sudoeste/Octogonal & 01 & 10 \\
\hline & 03 & & \\
\hline
\end{tabular}




\begin{tabular}{|l|l|l|l|l|}
\hline Taguatinga & 35 & 41 & 29 & 27 \\
\hline Varjão do Torto & 07 & 10 & 11 & 07 \\
\hline Total & 553 & 515 & 539 & 567 \\
\hline
\end{tabular}

Fonte: PCDF - Relatório de Análise Criminal nº 63/2009

Acessado em Ilanud/UNODC - 2011, pág 35

Com alterações de formatação do autor

Os números absolutos também podem representar a intensidade da reverberação que uma notícia de homicídio tem em uma localidade e a quantidade do alcance que a notícia tem na comunidade local quando há várias ocorrências, assim como o estranhamento quando não há a ocorrência e a sensação de insegurança pode aumentar quando há algum registro, como pode ser observado no quadro apresentado.

Essas concentrações de homicídios podem ser demonstradas na figura abaixo, que apresenta em destaque as áreas em que há maior incidência do crime e os locais sem registro da ocorrência do fato, fazendo com que houvesse maior probabilidade de sensação de insegurança nessas regiões pelo cometimento de homicídio do que em outras regiões.

Figura 1 Concentração de Homicídio em 2004. Distrito Federal

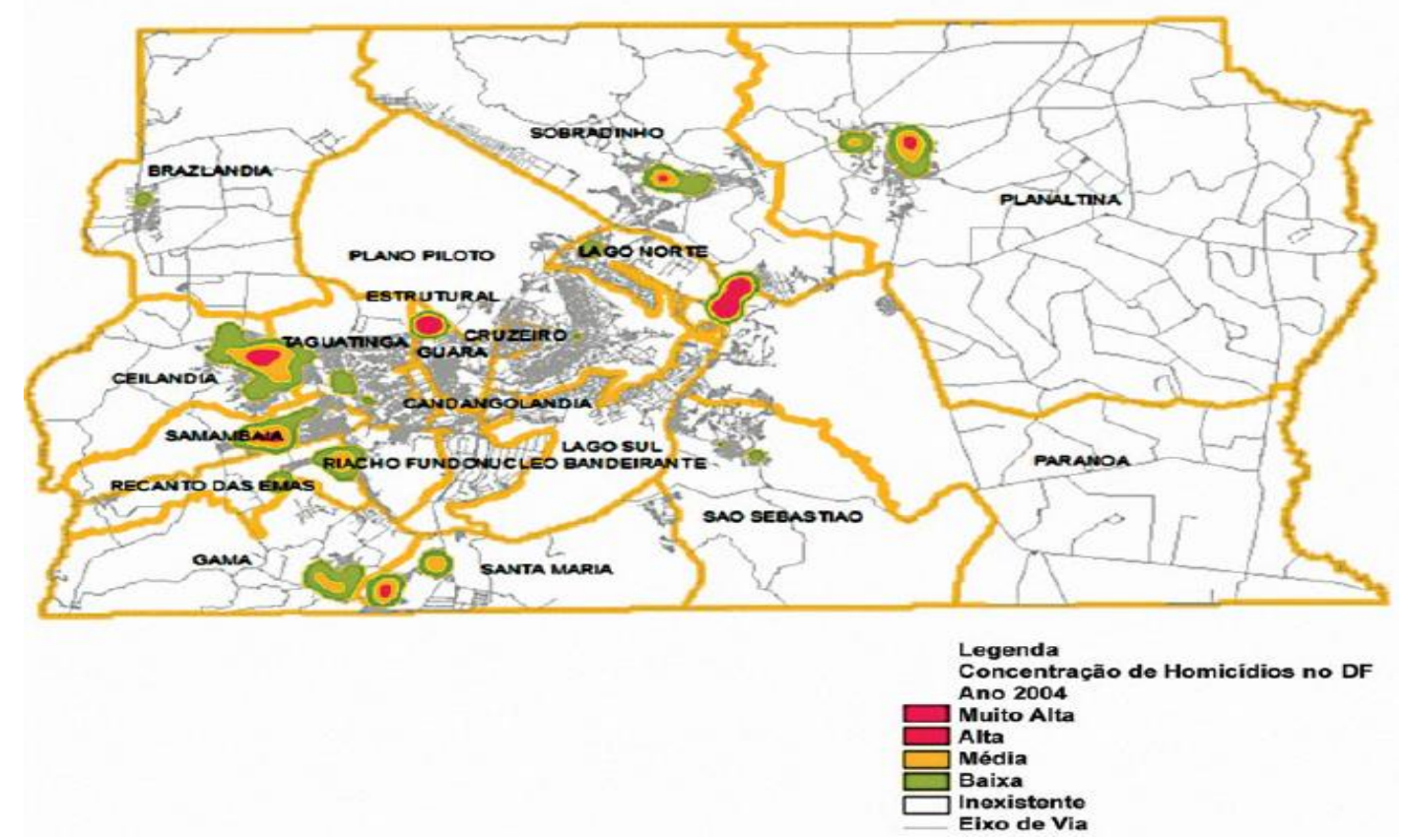

Fonte: NUGEO/GESP/DIFIS/SOSP/SSPDF, elaboração SSPDF, 2011

Disponível em Ilanud/UNODC - 2011 
Além da concentração dos homicídios, centrada nas periferias do Distrito Federal e com baixas taxas absolutas na área central, há outros crimes que também influenciavam a sensação de segurança no Distrito Federal que permitem que a sensação de segurança fosse influenciada pela possibilidade que qualquer cidadão poderia ser vítima nestes casos, como, por exemplo, o latrocínio (roubo seguido de morte), a lesão corporal seguida de morte, roubo de veículo e a transeunte, roubo em transporte coletivo e roubo com restrição da liberdade (sequestro relâmpago).

Novamente, apresentamos os números absolutos para poder inferir a possível repercussão que a notícia do ato pode influenciar na sensação da segurança ou na repercussão que tais crimes podem influenciar no processo de formação de uma agenda em segurança pública. Como este crime pode ser cometido em um local e registrado em outro, ou ainda não registrado por diversos motivos, apresentamos o consolidado no Distrito Federal.

Tabela 2 Valores Absolutos de incidência de crimes no Distrito Federal

\begin{tabular}{|l|l|l|l|}
\hline Crimes Registrados & 2005 & 2006 & 2007 \\
\hline Homicídio Doloso & 515 & 539 & 567 \\
\hline Latrocínio & 052 & 056 & 049 \\
\hline Lesão Corporal seguida de morte & 009 & 006 & 009 \\
\hline Roubo de veículo & 1.523 & 1.596 & 1574 \\
\hline Roubo a transeunte & 20.794 & 21.634 & 20.382 \\
\hline Roubo em transporte coletivo & 651 & 581 & 617 \\
\hline $\begin{array}{l}\text { Roubo com restrição da liberdade (sequestro } \\
\text { relâmpago) }\end{array}$ & 420 & 378 & 410 \\
\hline \begin{tabular}{l} 
Roubo a estabelecimento comercial \\
\hline
\end{tabular} & 1.664 & 1.784 & 1.917 \\
\hline
\end{tabular}

Fonte: FBSP, Anuários 2006, 2007 e 2008.

As ocorrências desses crimes, apesar de apresentar um comportamento constante de incidência, com pouca variação, causa grande impacto na sensação de segurança e nas vidas cotidianas dos cidadãos. Mesmo que não noticiados na mídia televisiva, impressa ou nos portais de notícias digitais, no mínimo 515 famílias ficaram marcadas no ano de 
2005 com a perda de um ente e esta perda repercutiu na vizinhança, nas redes de sociabilidade da vítima e dos familiares, entre outros que tomam conhecimento do fato; assim como mais de vinte mil pessoas que foram assaltadas e registraram e todos seus familiares e amigos que tomaram conhecimento do ocorrido; os mais de mil e quinhentos comerciantes e seus clientes e familiares; todos os passageiros e rodoviários vítimas dos mais de quinhentos assaltos em transporte coletivos por ano no Distrito Federal. Se as notícias transmitidas nos diversos veículos de comunicação têm impacto na sensação de segurança, não há como esquecer que um grupo tão grande tendo uma sociabilidade violenta não influencia na sensação de segurança dos demais cidadãos da localidade.

Já as taxas de incidência de crime para cada grupo de 100.000 (cem mil) habitantes traz a possibilidade de comparar com outras regiões ou as outras unidades federativas, independentemente do tamanho da população. Neste caso, os dados de 2005, 2006 e 2007 fazem parte do período anterior e ao momento inicial da formação da agenda de segurança pública que substanciou a implementação do Policiamento Comunitário do Distrito Federal.

Tabela 3 Taxas de Ocorrências de crimes por 100.000 habitantes. Distrito Federal

\begin{tabular}{|l|l|l|l|}
\hline Crimes Registrados & 2005 & 2006 & 2007 \\
\hline Homicídio Doloso & 22,47 & 22,6 & 23,3 \\
\hline Latrocínio & 2,26 & 2,3 & 2,0 \\
\hline Lesão Corporal seguida de morte & 0,39 & 0,2 & 0,4 \\
\hline Roubo de veículo & 66,46 & 67,0 & 64,7 \\
\hline Roubo a transeunte & 907,45 & 907,5 & 837,4 \\
\hline Roubo em transporte coletivo & 28,40 & 24,37 & 25,3 \\
\hline $\begin{array}{l}\text { Roubo com restrição da liberdade (sequestro } \\
\text { relâmpago) }\end{array}$ & 18,32 & 15,9 & 16,8 \\
\hline Roubo a estabelecimento comercial & 72,61 & 74,8 & 79,2 \\
\hline
\end{tabular}

Fonte: FBSP, Anuários 2006, 2007 e 2008.

Para uma percepção do quadro do índice de criminalidade violenta em relação a outras unidades federativas ${ }^{16}$, o Distrito Federal tinha uma taxa de roubo de veículo $(67,0)$

\footnotetext{
${ }^{16}$ Os dados fazem parte da análise do Fórum Brasileiro de Segurança Pública que categorizou grupos de informações segundo a qualidade dos dados, o Distrito Federal juntamente com Espírito Santo, Goiás,
} 
no ano de 2006 superior quase duas vezes ao estado de Goiás $(35,4)$, superior quase três vezes e meia a Minas Gerais $(18,6)$ e a Mato Grosso do Sul $(22,7)$, seis vezes superior a Santa Catarina $(10,4)$. A alta taxa também é registrada para roubo em estabelecimento comercial ou de serviço $(74,8)$ sendo quase o dobro em relação a Goiás $(26,8)$, Rio de Janeiro $(31,0)$ e a Mato Grosso $(44,7)$; quase o quádruplo em relação ao Pernambuco $(19,2)$ e Mato Grosso do Sul $(16,8)$; e quase o quíntuplo quando comparado à Santa Catarina $(17,4)$ e ao Espírito Santo $(14,9)$.

Já a taxa de sequestro relâmpago (roubo com a restrição da liberdade) registrada $(16,8)$ foi a maior entre todos que apresentaram os dados com maior confiabilidade: Espírito Santo $(9,0)$, Goiás $(1,1)$, Mato Grosso $(5,0)$, Mato Grosso do Sul $(1,1)$, Minas Gerais $(0,2)$, Pernambuco $(0,2)$, Rio de Janeiro $(1,0)$ e Santa Catarina $(0,6)$.

Todavia, a taxa que destoa é a de registro de roubo a transeunte no ano de 2006, de 907,5: Espírito Santo (130,0), Goiás (213,6), Mato Grosso (138,1), Mato Grosso do Sul $(78,1)$, Minas Gerais $(73,2)$, Pernambuco $(321,3)$, Rio de Janeiro $(297,8)$, Rio Grande do Sul $(299,8)$ e Santa Catarina $(39,2)$ têm registro muito inferiores de roubo a transeunte.

Desta forma, os indicadores que auxiliaram a composição do fluxo dos problemas coloca o Distrito Federal entre os que registram o maior número de ocorrência em vários crimes percebidos como violentos e que influenciam, de alguma forma, a sensação de (in) segurança. Esta é outro indicador difícil de ser mensurado, mas que está relacionado a quem percebe que está mais próximo dos crimes e que, no caso específico dos homicídios, está presente em todas as regiões administrativas, mas concentrado em algumas mais do que em outras.

Cabe ressaltar também que, mesmo considerando a qualidade dos dados de registros ou as subnotificações, há uma constante na quantidade de registro com os valores muito próximos um ano em relação a outro. Portanto, o impacto da criminalidade na vida cotidiana que influencia na sensação de segurança também é uma constante. Todavia, embora os problemas enfrentados são sempre relativos a sensação de insegurança ou os registros de ocorrências como indicadores para pautar a segurança pública como um problema a ser debatido, os atores que propõem soluções utilizam o espaço de debate, na maioria das ocasiões, para apresentar alternativas referentes ao trabalho dos policiais e, em muitos casos, ao trabalho dos policiais militares. 


\subsubsection{Fluxos das Soluções}

No terceiro fluxo há o conjunto de alternativas (policy alternatives). O modelo salienta que a solução não precisa necessariamente de um problema. Alguns formuladores de políticas públicas (policy communities) geram alternativas "próprias" do campo e outros "misturam" soluções com novas propostas. As mais viáveis técnica e economicamente sobrevivem. Assim, de uma grande quantidade de soluções apenas algumas destacam-se para os tomadores de decisões. Nem sempre essas soluções são consensuais. A comunidade de formuladores é composta por especialistas, pesquisadores acadêmicos, funcionários públicos, assessores parlamentares, assessores de grupos de interesses, e essa multiplicidade faz que algumas comunidades sejam fragmentadas, por isso, necessita de um processo de difusão para que seja aceita por todos que a compõem. Assim, nem sempre há a relação sequencial e direta problema-solução e nem sempre há um grupo de pressão por determinadas alternativas, mas, segundo o modelo, o reconhecimento da ideia, promovido pela difusão, ganha centralidade na análise.

As redes estabelecidas nos campos de controle social nacional e internacionalmente difundem soluções que, naqueles países com determinadas características sociais, políticas, culturais, econômicas e jurídicas tiveram êxito em controlar a criminalidade ou diminuíram índices da criminalidade violenta. Há uma grande quantidade de soluções encontradas em outros países ou estados do Brasil que são difundidas nas Feiras de Segurança, promovidas por empresas do segmento, nas viagens de estudos promovidas pelas instituições de segurança, nos congressos acadêmicos promovidos pelas comunidades científicas, entre outros. Assim, há modelos de policiamento que destoam do policiamento tido como tradicional no Brasil.

\subsubsection{A Difusão de Modelos de Policiamento}

Há vários modelos de policiamento que tentam aumentar a legitimidade das ações policiais e o controle social interno e externo das instituições policiais (COSTA, 2004). Como alternativa aos modelos que priorizam a repressão policial e a ação reativa, o Policiamento Comunitário tem se destacado como uma filosofia de trabalho, isto é, é uma 
relação afetiva com a comunidade e, segundo Marceneiro (2009:113), "deve ser interpretada como filosofia organizacional indistinta a todos os órgãos de Polícia".

Segundo Rosenbaum (2002:30), por ser uma “política moderna” para perceber e solucionar as causas da violência e do crime, alguns gestores de instituições policiais têm utilizado este "rótulo" de forma "abusiva" para justificar todo tipo de ação e programa policial. A solução moderna difunde-se em vários países e nos estados brasileiros.

Segundo Cerqueira (2001), na década de 1985, o Governo do Estado de São Paulo cria os Conselhos Comunitários de Segurança compostos por delegados, representantes da polícia militar. Na mesma década no Rio de Janeiro, o governo de Leonel Brizola modifica as modalidades de policiamento. A partir da década de 1990, várias unidades da federação iniciam o debate de implementação do policiamento comunitário, entre elas Espírito Santo, Bahia, Pernambuco, (CERQUEIRA, 1998). Em 1990, em Belo Horizonte, foi implantado o policiamento que pretendia diminuir a distância entre os policiais e a população da capital, foi o chamado policiamento distrital.

Em 1995, iniciou-se o processo no Distrito Federal na cidade de Samambaia. Em 2002, a cidade do Guará iniciou a implantação dos Conselhos Comunitários de Segurança Pública local. Os policiais foram escolhidos e treinados por uma semana para executar o policiamento a pé e em bicicletas para priorizar as áreas comerciais e manter contatos com a comunidade assistida fornecendo o número de telefone celular. (CARDOSO apud CANÁRIO DE OLIVEIRA, 2005).

Todavia, a parte das interpretações que foram difundidas nestas décadas e nestas localidades indicam algumas características que são consensos. Segundo Trojanowicz e Bucqueroux (1994) o Policiamento Comunitário é definido como

[...]uma filosofia e uma estratégia organizacional que proporciona uma nova parceria entre a população e a polícia. Baseia-se na premissa de que tanto a polícia quanto a comunidade devem trabalhar juntas para identificar, priorizar, e resolver problemas contemporâneos tais como crime, drogas, medo do crime, desordens físicas e morais, e em geral a decadência do bairro, com o objetivo de melhorar a qualidade geral da vida na área. (TROJANOWICS; BUCQUEROUX, 1994 apud MARCINERIO, 2009:113)

Marcinerio (2009) destaca ainda algumas características para diferenciar a filosofia de polícia comunitária e a polícia tradicional: 
a) Polícia Tradicional: o papel principal das instituições policiais é a resolução ou a repressão do crime; um dos principais coeficientes de eficiência da atividade policial é o tempo de resposta da solicitação; o policial trabalha para a marginalidade local, o que corresponde a menos de $2 \%$ da população; as rondas ostensivas, ou patrulhas, são distribuídas conforme estatísticas que demonstram os registros de ocorrências, entre outras características; e

b) Polícia comunitária: a polícia é o público e o público é a polícia; a polícia representa mais uma instituição do campo de controle responsável pela manutenção e melhoramento da qualidade de vida; a eficácia da polícia é mensurada pela ausência do crime e da desordem pública; o foco da ação policial são os problemas e as preocupações dos cidadãos da comunidade; um dos coeficientes ou indicadores da eficiência da atividade policial ou da instituição policial é o grau da legitimidade das ações policiais e a cooperação do público com os policiais; o policial presta conta de suas atividades ao superior ou comandante e à comunidade, entre outras características.

Trojanowicz e Bucqueroux (1994) apud Marcineiro (2009) apresentam ainda dez princípios que orientam as políticas, as práticas e os procedimentos à filosofia de trabalho de Policiamento Comunitário: a filosofia e estratégia organizacional; o comprometimento com a concessão de poder à comunidade; o policiamento descentralizado e personalizado; a resolução preventiva de problemas a curto e a longo prazo; ética, legalidade, responsabilidade e confiança; extensão do mandato policial; ajuda para as pessoas com necessidade especiais; criatividade e apoio básico; mudança interna; e construção do futuro.

Esses princípios coadunam com os elementos do Policiamento Comunitário desenvolvidos por Skolnick e Bayley (2006). Segundo os autores, há quatro elementos que tendem a nortear as políticas públicas para a construção de filosofias comunitárias nas comunidades policiadas:

a) organizar a prevenção do crime tendo como base a comunidade: vários programas comunitários foram desenvolvidos tendo como referência a opinião e a participação da comunidade como, por exemplo, programas de Vigilância do Bairro que envolvem a vigilância pública, a marcação da propriedade e a segurança da moradia; 
b) reorientação das atividades de patrulhamento: diferentemente das patrulhas rotineiras, há a preocupação de orientar as várias modalidades de policiamento com a necessidade da população. Assim, destacam-se neste elemento de policiamento os Kobans japoneses (postos comunitários com o policial morador do local) e os patrulhamentos verticais realizados em prédios em Cingapura; Policiamento Orientado para o Problema como técnica de aumentar a eficácia e a eficiência.

c) Aumento da responsabilidade da polícia: este elemento exige que a polícia tenha uma nova postura de ter o mínimo de tolerância com os indivíduos que não são policiais. Outra exigência deste elemento do policiamento comunitário é a reciprocidade da comunicação, isto é, o "[...] pode falar sobre prioridades, estratégias, enfoques táticos, e mesmo sobre o comportamento dos policiais enquanto indivíduos, e também sobre tudo isso" (SKOLNICK; BAYLEY, 2006:32); e

d) Descentralização do comando: assim, o policiamento deve ser adaptável. Segundo SKOLNICK e BAYLEY (2006), o policiamento comunitário descentraliza o comando para ganhar a flexibilidade necessária para dar forma estratégias policiais em determinadas áreas.

Há várias interpretações de como instrumentalizar essas orientações. No Japão e em Cingapura, o símbolo físico do policiamento comunitário são os postos policiais. Os koban no Japão e os Neighborhood Police Posts (NPPs) são as referências locais de policiamento e são construídos em todos os espaços urbanos disponíveis próximos. Os japoneses optaram em construir próximo às estações ferroviárias, entre fileiras de lojas, intersecção de rodovias movimentadas, em lotes residenciais e próximo a templos religiosos. Já em Cingapura, os postos foram construídos nas repartições públicas e em espaços próximos às moradias e ao comércio.

Essa referência física permite aos policiais interagir de forma diferente com a população e prestar serviços que antes seriam impensáveis como, por exemplo, entrega de cartas de profissionais que estão trabalhando por um curto período na área. Todavia, não é somente a construção física que define os modelos de policiamento. Segundo Moore (2003), o que realmente o define são as táticas operacionais: o patrulhamento, a resposta rápida e a investigação. 
A modalidade de policiamento também pode mudar com as construções dos postos policiais e a nova estratégia organizacional. O patrulhamento motorizado perde espaço e o patrulhamento a pé torna-se uma estratégia para fazer com que o policial integre mais suas ações com a comunidade local e possa personalizar suas ações cotidianas.

As ações policiais ganham mais legitimidade por reforçar o compartilhamento da responsabilidade do controle social na comunidade, principalmente porque é a comunidade local que nomeia os problemas e participa do processo decisório de como solucioná-los, compartilhando ações neste processo. Um dos objetivos do policiamento comunitário é fazer com que as "instituições comunitárias” floresçam (MOORE, 2003), que os laços comunitários fortaleçam (ROSENBAUM, 2002).

Além do rótulo de policiamento moderno, a imagem de que o policiamento comunitário é mais "eficaz e eficiente" soma-se às críticas ao modelo tradicional de policiamento e ganha mais espaço nas agendas governamentais para possíveis mudanças.

Entre as críticas, podemos citar: a fragilidade dos métodos (operações policiais preventivas); os limites da forma reativa (alguns crimes não são denunciados e as vítimas ou testemunhas não são ouvidas para acionar a polícia); a prevenção insuficiente por monopolizar o controle; as solicitações por telefone dos cidadãos nem sempre são para crime; a profissionalização incompleta, por estar subordinada e dependente da influências políticas; e o crescimento da segurança privada (Moore, 2003).

Assim, já havia um desgaste na solução tradicional e diversos atores produziam outras soluções, mesmo que convergindo para o Policiamento Comunitário enquanto estratégia de policiamento ou como estratégia de mudança da cultura policial para mudar as práticas diárias. Todavia, o campo de controle do delito tem diversos atores com instrumentos diferentes para tentar induzir a aceitação das suas soluções

\subsubsection{Atores, soluções e instrumentos de aceitação}

Anteriormente à escolha da instalação dos postos policiais como forma de implementar o Policiamento Comunitário no Distrito Federal, havia a ação de vários atores constituintes de soluções na área de segurança pública com propostas e intenções diferentes. Agindo de forma isolada ou nas agências públicas e privadas, oferecendo 
diversos tipos de contrapartidas caso aderisse à sua propostas, estes atores tinham papel fundantes na escolha da alternativa como política pública.

Da mesma forma que havia múltiplas agências no sistema de controle dividindo atribuições sobre o mesmo espaço territorial, há também vários grupos que apresentam soluções para subsidiarem as decisões acerca das conflitualidades, violência e para a consolidação da cidadania mediada pelas agências da segurança pública. Assim, os diversos atores dos fluxos das soluções pertencem a uma complexa rede verticalizada pelas características instituídas por lei na divisão das responsabilidades entre a União, os Estados e os Municípios, que também têm poderes de fomento de políticas, mas também em relações horizontais pelo poder de influência recíprocas não hierarquizadas que existem na esfera governamental, intercâmbio de experiências, entre outras.

Esta relação verticalizada de implementar políticas públicas foi atribuída pela Constituição de 1988, não houve a regulamentação do artigo 23 da Carta Magna que trata das atribuições concorrentes entre os membros da República Federativa do Brasil. Desta forma, segundo Lima (2012), a proeminência dos Estados da Federação se deve a este vácuo legal. Todavia, foi a partir do segundo mandato do Governo Cardoso que o Governo Federal iniciou explicitamente a construção de mecanismos de indução de políticas de segurança pública estaduais e municipais a partir de determinados prismas com uma política nacional de segurança pública (SOARES, 2007).

Neste bojo, foram criadas pelo Governo Federal várias estruturas com novos atores para formularem alternativas para os poderes executivos estatuais e municipais frente à questão da criminalidade e à insegurança social. Um marco que apresenta marcas deste processo foi formulado por especialistas no Ministério da Justiça, o Plano Nacional de Segurança Pública (PNSP).

Outro ator instituído pelo Governo Federal que figura neste cenário é a Secretaria Nacional de Segurança Pública do Ministério da Justiça (SENASP/MJ). Por respeito à autonomia das Unidades Federativas da nação, a SENASP/MJ não tem poder legalmente constituído para impor ações, doutrinas ou qualquer política aos Estados e Municípios e às agências da segurança pública. Assim, toda e qualquer política que a SENASP/MJ desenvolva com os Estados e Municípios é por convênio entre os entes.

Além de assessorar o Ministro da Justiça, também planeja, acompanha e avalia a implementação de programas do Governo Federal na área de segurança; elabora propostas para alterar a legislação na temática, tanto para o setor público quanto para o 
setor privado; estimular o reaparelhamento das agências de segurança pública; realizar e fomentar estudos e pesquisas com o objetivo de diminuir os índices da criminalidade e da violência; identifica apoios de organismos internacionais e nacionais de caráter público ou privado; identifica, documenta e fomenta experiências inovadoras no campo da segurança pública; e estimula e propõe às agências estaduais e municipais de segurança a elaboração de planos integrados de segurança pública para controlar ações criminosas e ações que gerem índices de criminalidade e violência, assim como estimular ações de prevenção da violência e da criminalidade (MINISTÉRIO DA JUSTIÇA, 2007).

Muitos desses objetivos foram realizados por convênios com governos estaduais e municipais. Os termos dos convênios sempre informavam quais os objetivos, quais os requisitos que os governos deveriam cumprir para obter o financiamento do Governo Federal. Assim, os projetos apresentados pelos governos estaduais e municipais deveriam seguir os termos de referência que a SENASP/MJ estava propondo.

Em 2005 é criada a Rede de Ensino a Distância da SENASP/MJ para possibilitar que os agentes da segurança pública tenham acesso à formação continuada proposta pelo Governo Federal. Essa formação é integrada e com os conteúdos e a qualidade seguindo os critérios da SENASP. O objetivo desta rede federal de ensino é disseminar doutrinas e práticas e promover a consolidação de políticas públicas.

A capilaridade destes programas da SENASP/MJ é maior com a Rede EaD. Vários cursos foram oferecidos diretamente aos agentes de segurança pública estaduais e municipais em ciclos, mediante convênios com os Estados e Municípios. Cursos estes que seguem as doutrinas orientadoras do Governo Federal de como deve ser a ação policial e as ações destinas à redução da criminalidade e da violência. Entre os cursos oferecidos, Policiamento Orientado para o Problema (POP), Mediação de Conflitos, Atuação Policial frente a Grupos Vulneráveis, Direitos Humanos e Policiamento, Formação de Conselheiros em Direitos Humanos, Planejamento Estratégicos, Uso da Informação em Gestão em Segurança Pública, Sistema e Gestão em Segurança Pública, Gerenciamento de Crise, Violência Criminalidade e Prevenção, Análise Criminal, Atendimento à Mulher em Situação de Violência, Enfrentamento da Exploração Sexual de Crianças e Adolescentes, Promotor em Policiamento Comunitário, entre vários outros cursos com duração de 40 (quarenta) a 60 (sessenta) horas, completamente gratuitos e à distância, inclusive a avaliação. Os agentes de segurança pública podiam realizar os cursos na íntegra à distância e, para aqueles que não dispunham de acesso à internet, a 
SENASP disponibilizou 257 (duzentos e cinquenta e sete) telecentros distribuídos nas 27 unidades da federação conveniadas.

Os cursos foram disponibilizados em três ciclos por ano com aproximadamente 150.000 (cento e cinquenta mil) alunos. Cada aluno pôde cursar até 2 (dois) cursos por ciclo. Até o $28^{\circ}$ Ciclo de aula havia um total de 591.729 (quinhentos e noventa e um mil e setecentos e vinte e nove) alunos cadastrados na Rede que realizaram 2.870 .633 (dois milhões, oitocentos e setenta mil, seiscentos e trinta e três) matrículas em cursos.

Na figura abaixo há a distribuição das matrículas em cursos realizados pela Rede EaD da SENASP/MJ, mediante convênio com as Secretarias Estaduais de Segurança Pública

Gráfico 3 Distribuição das Matrículas em Cursos Ead da SENASP por Ano

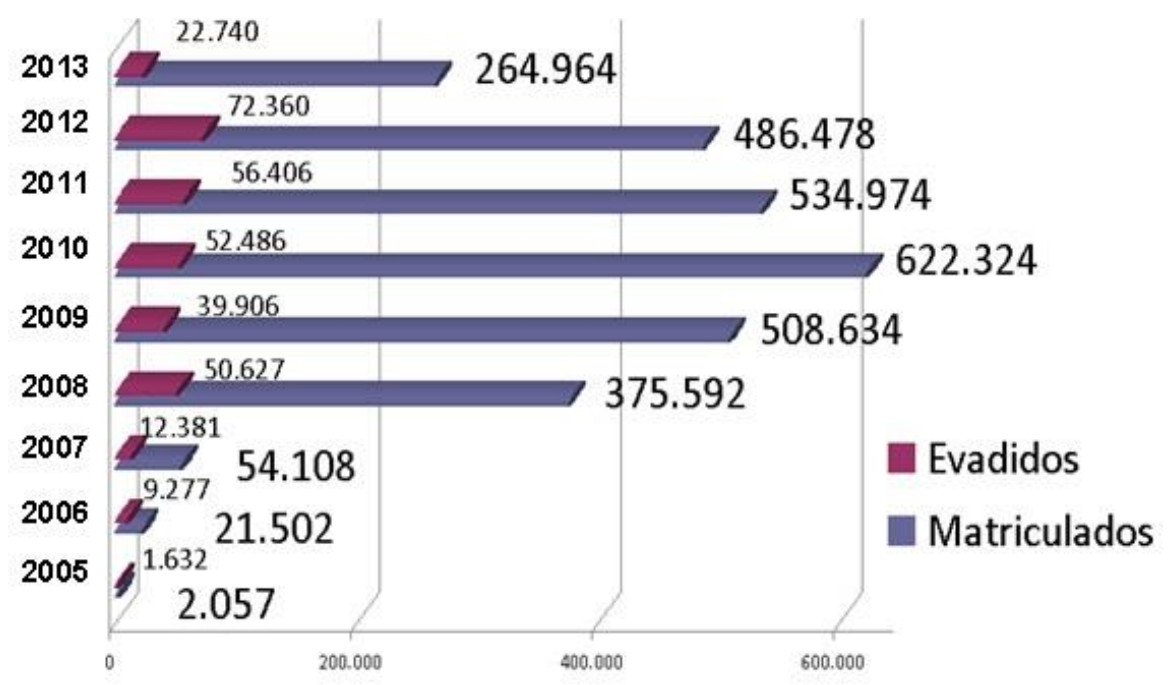

Fonte: SENASP/MJ

Os dados do gráfico são referentes às matrículas realizadas até o $28^{\circ}$ ciclo de cursos. Até dezembro de 2014 foram realizados 32 (trinta e dois) ciclos para todas as unidades federativas conveniadas. O período de implementação da política de segurança pública objeto desta pesquisa inicia-se em 2007 no Distrito Federal, com marco de implementação em 2008, ano que se inicia o maior fomento da SENASP para a formação continuada dos agentes de segurança pública sob a orientação de um doutrina que privilegia a participação da sociedade, o respeito aos direitos humanos e a prática policial no policiamento comunitário. 
Mesmo que fragmentado, ao observar os cursos oferecidos pela SENASP, podese perceber que a formação continuada é uma política que tenta mudar as formas tradicionais de resolução de conflitos para policiar sob um planejamento orientado para o problema, integrando a gestão na segurança pública, entre outros, que são temáticas apresentadas para debates em alguns cursos que são basilares para o policiamento comunitário.

Além da formação continuada, a SENASP/MJ também ofereceu como alternativas a formação dos agentes de segurança pública, propondo a Matriz Curricular Nacional para a Formação em Segurança Pública. A principal característica da Matriz, segundo a própria agência do Ministério da Justiça, é a de ser um referencial teórico-metodológico para orientar as formações dos profissionais da segurança pública estadual (policial militar, policial civil e bombeiros militares), independente do nível da formação ou a modalidade de ensino (SENASP, 2009). Apresentada em 2003, com a primeira revisão em 2005, e em 2009 uma versão revisada e ampliada, a Matriz contempla diversos temas, e, como demonstra a tabela abaixo com a sugestão de Malha Curricular, integra conhecimentos para os vários agentes de segurança:

Quadro 12 Malha Curricular SENASP

\begin{tabular}{|c|c|c|}
\hline \multicolumn{2}{|c|}{ Área temática } & Disciplinas \\
\hline \multirow{4}{*}{ I } & \multirow{4}{*}{$\begin{array}{l}\text { Sistema, Instituições e Gestão } \\
\text { Integrada em Segurança Pública }\end{array}$} & Sistema de Segurança Pública no Brasil \\
\hline & & Fundamentos da Gestão Pública \\
\hline & & Fundamentos da Gestão Integrada e Comunitária \\
\hline & & Abordagem Sócio psicológica da violência e do Crime \\
\hline \multirow{3}{*}{ II } & \multirow{3}{*}{$\begin{array}{l}\text { Violência, Crimes e Controles } \\
\text { Sociais }\end{array}$} & Abordagem Sócio psicológica da violência e do Crime \\
\hline & & Criminologia Aplica a Segurança Pública \\
\hline & & Análise de Cenários e Riscos \\
\hline \multirow{2}{*}{ III } & \multirow{2}{*}{ Cultura e conhecimento Jurídico } & Direitos Humanos \\
\hline & & Fundamentos do Conhecimento Jurídicos \\
\hline \multirow{2}{*}{ IV } & \multirow{2}{*}{$\begin{array}{l}\text { Modalidades de Gestão de } \\
\text { Conflitos e Eventos Críticos }\end{array}$} & Prevenção, Mediação e Resolução de Conflitos \\
\hline & & Gerenciamento Integrado de Crises e Desastre \\
\hline \multirow{2}{*}{$\mathrm{V}$} & \multirow{2}{*}{$\begin{array}{l}\text { Valorização Profissional e Saúde } \\
\text { do Trabalhador }\end{array}$} & Relações Humanas \\
\hline & & Saúde e Segurança Aplicada ao Trabalho \\
\hline VI & & Língua e Comunicação \\
\hline
\end{tabular}




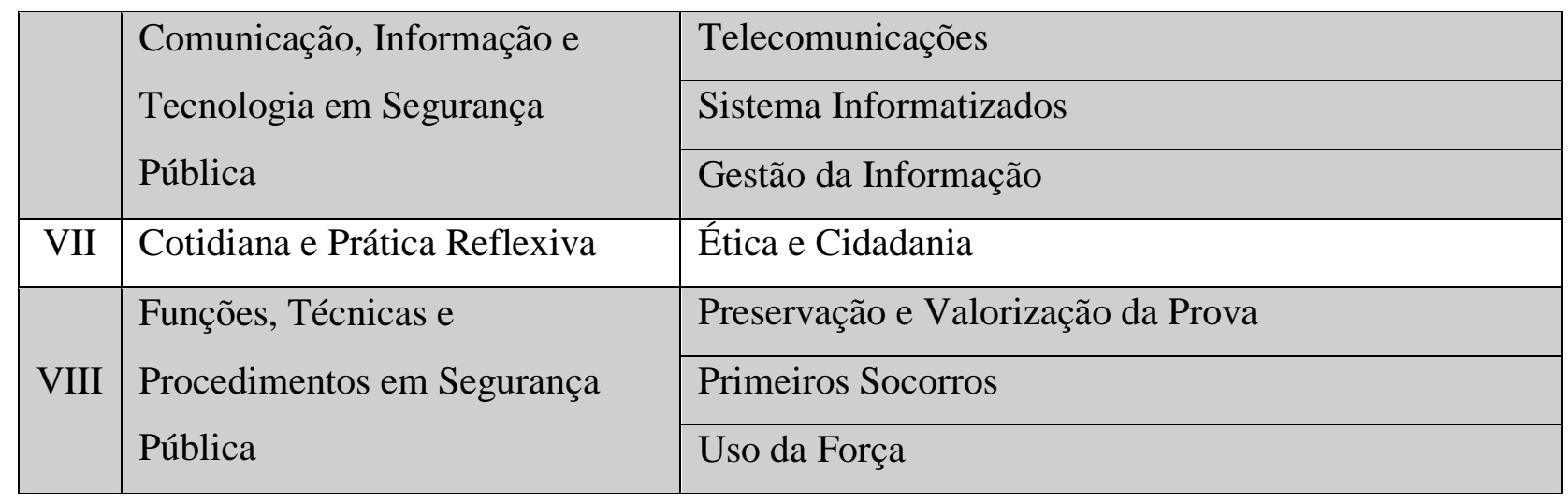

Fonte: Senasp, 2009

Essa Malha Curricular é composta por núcleos comuns de disciplinas, que foram agrupadas em áreas temáticas que congregam conteúdos conceituais, procedimentais e atitudinais. A sugestão da Senasp/MJ foi que a grade compusesse até 40\% (quarenta por cento) do total de horas/aulas do currículo.

Além da Malha Curricular, a Matriz Curricular apresentava também as ementas das disciplinas como sugestão para a formação dos agentes de segurança. A composição é didaticamente apresentada com o nome da disciplina, mapa de competências da disciplina, entre outras características próprias. O que chama atenção é que a temática do policiamento comunitário e dos direitos humanos transversaliza todas as disciplinas e seus fundamentos estão presentes nos objetivos das disciplinas, tanto para a constituição dos conceitos, como para orientar os aspectos atitudinais, quanto para os aspectos procedimentais.

Assuntos como, por exemplo, Conselhos Comunitários de Segurança, Mobilização comunitária, Gestão Integrada, formação de redes comunitárias, entre outras alinhados com a temáticas são percebidos facilmente na maioria das ementas das disciplinas.

A formação profissional do agente de segurança pública e a formação continuada, seguindo alguns viés teóricos, são algumas soluções da SENASP/MJ apresentadas como solução para auxiliar os governos estaduais e municipais para a redução da criminalidade e da violência. Estes viés teóricos são frutos de debates produzidos pelos especialistas da agência federal e de pesquisas fomentadas pelo Ministério da Justiça.

Por não haver obrigatoriedade da formação continuada nos moldes da SENASP nas agências de segurança, foi criado o programa Bolsa Formação como estímulo para que houvesse o máximo de aderência ao ensino continuado. Tendo como público-alvo 
policiais militares, policiais civis, bombeiros militares, agentes penitenciários, agentes carcerários e guardas-municipais que recebiam até $\mathrm{R} \$ 1.700,00$ (um mil e setecentos reais) de renda, mediante convênio entre a SENASP e os Estados e Municípios. O Governo Federal oferecia uma bolsa de $\mathrm{R} \$ 443,00$ (quatrocentos e quarenta e três reais) por mês para o agente de segurança pública estadual ou municipal que realizasse com aproveitamento um curso habilitado no período de 12 (doze) meses.

Acre, Alagoas, Amapá, Amazonas, Bahia, Ceará, Espírito Santo, Maranhão, Mato Grosso, Mato Grosso do Sul, Pará, Paraíba, Paraná, Pernambuco, Piauí, Rio de Janeiro, Rio Grande do Norte, Rio Grande do Sul, Rondônia, Roraima, Santa Catarina, São Paulo (somente a Administração Penitenciária), Sergipe e Tocantins aderiram à alternativa de política de formação da Senasp. O Distrito Federal não pôde se conveniar, pelo fato de a renda dos agentes de segurança ser maior que o teto estabelecido pelo Governo Federal. (SENASP, 2014).

Além de apresentar alternativas aos governos na área da educação continuada, nas entrelinhas da oferta dos cursos havia também qual doutrina os policiais deveriam seguir e como suas condutas deveriam ser (re) orientadas. Os cursos eram ofertados para todas as agências de segurança pública e em todos os níveis governamentais. Quando os governantes municipais e estaduais optavam por essa solução de ter o compartilhamento da formação, também optavam por seguir a matriz curricular elaborada pela Senasp/MJ.

Outros cursos de formação de Especialistas foram ofertados para agentes de segurança pública. A partir de 2006 foram realizados convênios com Instituições de Ensino Superior (IES) para que oferecessem cursos de pós-graduação latu sensu na área de segurança pública, especificamente especializações em Policiamento Comunitário, em Gestão Integrada em Segurança Pública, Análise Criminal, entre outros, na modalidade EaD e presencial ${ }^{17}$. Os custos dos cursos eram de responsabilidade do Governo Federal. O principal critério para acesso a esses cursos era que o aluno fosse agente de segurança pública e estivesse na ativa, não havendo restrições por cargo ou agência de segurança municipal ou estadual.

A aproximação do Governo Federal com as IES também resultou em fomento à pesquisa científica para auxiliar as políticas públicas de segurança no desenho de

\footnotetext{
${ }^{17}$ Para Naylane Pinto, Haydée Caruso, Luciane Patrício, Elizabete Albernaz e Vanessa Cortes (SENASP, 2014), este foi o primeiro passo da constituição da RENAES, ao credenciar instituições de ensino superior e transferir recursos de todo Brasil, sejam instituições públicas ou privadas.
} 
diagnósticos e alocação de recursos nos três níveis de governo. Para tanto, pesquisas que apresentam o Perfil das instituições de segurança pública (SENASP, 2013a), sobre o papel das mulheres na segurança pública (2013b), sobre as formas de organizações, estruturas e funcionamento dos serviços de perícia forenses estaduais (2012), ou ainda sobre índices de criminalidade, sobre a relação de direitos humanos e segurança pública e análise e diagnóstico de políticas públicas foram algumas pesquisas fomentadas para auxiliar os governantes estaduais e municipais na elaboração e implementação de políticas públicas.

No Brasil, as IES já atuavam nesta temática antes das ações do Ministério da justiça ter aberto o espaço de debate no poder executivo sobre segurança pública, criminalidade, violência, conflitualidades, entre outras temáticas correlatas para estimular alternativas para a concepção de novas políticas de segurança pública. Diversos núcleos de pesquisa, entre eles o Núcleo de Estudo da Violência (NEV) da Universidade de São Paulo, o Núcleo de Estudo e Pesquisa em Criminalidade, Violência e Política Pública de segurança (NEPS) da Universidade Federal de Pernambuco, o Núcleo de Estudos da Cidadania, Conflito e Violência Urbana (NECVU) da Universidade Federal do Rio de Janeiro, o Núcleo de Estudos sobre Violência e Segurança (NEVIS) da Universidade de Brasília, o Grupo de Pesquisa Violência e Cidadania (GPVC) da Universidade Federal do Rio Grande do Sul e o Centro de Estudos e Criminalidade e Segurança Pública (CRISP) da Universidade Federal de Minas Gerais se consolidaram como referências acadêmicas em segurança pública e já atuavam como centros produtores de propostas de políticas públicas ou como atores de análises e de proposição de políticas de segurança pública, construindo indicadores, pesquisando atores, grupos ou instituições envolvidos, ou apresentando propostas inovadoras, entre várias outras formas de contribuição.

Além dos núcleos constituídos nas IES, há outros espaços construídos pelos acadêmicos que se dedicam ao debate sobre políticas de segurança pública. O Fórum Brasileiro de Segurança Pública (FBSP), criado em 2006 por especialistas em segurança pública, com o objetivo de

promoção da paz, da cidadania e dos direitos humanos, por meios de ações que facilitem o intercâmbio e a difusão de ideias e conhecimentos para o aperfeiçoamento da organização social, das práticas policiais e dos serviços de segurança pública no Brasil, a fim de e promover a redução da criminalidade, da violência e da sensação de insegurança da sociedade (FBSP, $\operatorname{art} 4^{\circ}, 2012$ ) 
Todavia, mesmo direcionando suas ações para os mesmos objetivos das agências de segurança pública, a atuação é realizada de forma somente propositiva. Assim, as ações do FBSP estão voltadas para realizar pesquisas científicas e estudos técnicos acadêmicos na área de atuação policial e das políticas e programas de segurança pública no Brasil; para a produção e edição de publicações, manuais e materiais didáticos; realização de cursos, oficinas e outras iniciativas para a disseminação no Brasil de conhecimentos e práticas inovadoras e eficazes, especificamente na área de policiamento (FBSP, art $5^{\circ}$, 2012).

Esta rede acadêmica que desenvolvia suas atividades em núcleos, centros de pesquisas ou por iniciativas de alguns cientistas das IES, e envolvia várias áreas de conhecimento, entre eles, sociológicos, antropológicos, econômicos, referentes à Administração e à Ciência Política. Os que já estavam voltados para este debate ganharam maior visibilidade no cenário de construção de política pelos gestores na rede dos governos e com a atuação da SENAESP/MJ. Foi mais uma abertura para o conhecimento científico entrar na arena política a partir do fluxo de soluções.

Em 2012, com a Portaria $n^{\circ} 1.148-M J$, de 12 de junho, foi oficialmente institucionalizada a Rede Nacional de Altos Estudos em Segurança Pública (RENASP), mas que informalmente já estava atuante desde 2006 pelos convênios estabelecidos entre as IES e o Ministério da Justiça ao matricularem mais de 5.600 (cinco mil e seiscentos alunos) em 25 (vinte e cinco) unidades federativas com a oferta de, aproximadamente, 140 (cento e quarenta) cursos. Com tal portaria, estabeleceu-se que a Renaesp fomentaria estudos e pesquisas voltadas para a atualização das instituições de segurança pública; valorizaria os profissionais de segurança pública e os incentivaria a participarem de cursos; promoveria estudos, pesquisas e indicadores de violência, criminalidade, entre outros relacionados à segurança pública (MINISTÉRIO DA JUSTIÇA, 2012). Acrescente-se ainda, como objetivo da RENASP, o incentivo à implementação de núcleos e centros de estudos e pesquisas dedicados à segurança pública.

A RENAESP é uma rede constituída por cooperação entre as IES públicas (federais, estaduais e municipais) ou privadas e o SENASP/MJ. Todavia, esta parceria é conduzida segundo algumas diretrizes construídas e indicada pela SENASP/MJ. No Edital número 06 de 21 de Junho de 2012 da agência federal de segurança pública, há como critério de seleção de propostas de cursos de pós-graduação latu sensu nas seguintes áreas de conhecimento: organização e gestão das instituições de segurança pública; 
estruturação e modernização das instituições de segurança pública; gestão do conhecimento e de informação sobre violência e criminalidade; controle interno e externo dos órgãos de segurança pública e participação social; valorização e formação profissional; programas de redução da violência; programas de prevenção da violência e da criminalidade; segurança pública e direitos humanos; integração das instituições de segurança pública no Brasil, entre várias outras áreas.

Assim, as IES no Brasil que faziam parte das Renaesp tinham suas ações sobre a temática Segurança Pública conduzidas pela SENASP/MJ para proporem cursos de pósgraduação. Há autonomia nas IES quando esta produção de conhecimento e a elaboração de propostas para a diminuição da criminalidade, da violência e dos conflitos quando desenvolveram suas atividades fora do escopo imperativo da Renaesp para o financiamento de cursos. Todavia, mesmo sob a indução de soluções da SENASP, as IES, ao desenvolverem os cursos em parceria, provocaram um movimento que ainda está se consolidando no campo social da segurança pública, a formação de um sistema perito composto por agentes de segurança pública.

Sistemas peritos são "sistemas de excelência técnica, ou competência profissional que organizam grandes áreas dos ambientes material e social em que vivemos" (GIDDENS, 1991:35), isto é, são sistemas de conhecimentos próprios do campo social que distancia o indivíduo da crença e estabelece uma confiança ao decidir tomar determinada decisão por ela ser uma alternativa calculada.

Segundo Giddens (1991), um sistema perito propicia confiança também nos outros indivíduos que estão fora do sistema e, no nosso caso, do campo social da segurança pública, pois todos são leigos em vários assuntos, sobre vários temas e constantemente consultam peritos de modo irregular, todavia, todos podem ser atingidos de alguma forma no sistema ou pelas decisões dos peritos.

Como foi mencionado, até o momento há produção científica sobre violência, criminalidade, conflitualidade, desvio, entre outros temas, principalmente nas cadeiras da Sociologia, da Ciência Política, da Antropologia, da Psicologia, da Economia, da Administração, entre tantas outras áreas de conhecimento. Em suma, quem debate segurança pública no Brasil, majoritariamente, são os acadêmicos.

A Renaesp, nesse sentido, propicia um espaço para que os profissionais em segurança pública pudessem/possam iniciar sua carreira enquanto produtor de conhecimento sobre segurança pública, ser um perito no sistema, um agente reflexivo 
sobre o habitus do campos social da segurança pública e seus reflexos na sociedade, todavia, inicialmente focando seus estudos e pesquisas sobre os temas propostos pelo Governo Federal.

Vale destacar que os agentes de segurança pública já produziam e propunham políticas públicas aos governantes. São também atores que apresentam alternativas e contribuem para compor o fluxo de soluções de constituição das políticas de segurança pública, todavia, quando não estão nas IES, estão aglutinados nos grupos representativos das categorias das agências. As lutas por direitos trabalhistas, garantindo direitos adquiridos ou exigindo maior quantitativo de agentes de uma determinada categoria, conduz linhas de políticas públicas como alternativas à demandas apresentadas. Assim, cada associação representativa produzia discursos sobre políticas de segurança pública para legitimar suas demandas trabalhistas. São proposições de políticas de segurança em que o autor da proposta e o executor estão no mesmo plano. Quando o Sindicato dos Policiais Civis do Distrito Federal apresenta a demanda por contratação de agentes de polícia, por exemplo, há uma linha discursiva que conduz para uma política de segurança pública que privilegia a investigação policial. O mesmo acontecesse quando algumas reivindicações das Associações de Delegados e outras categorias que podem alterar a composição da Secretaria de Segurança do Distrito Federal, estabelecer Políticas de Segurança Pública, Programas e Ações. Se a SENASP/MJ tem o financiamento para motivar a aderência às políticas propostas, as associações, enquanto produtoras de alternativas, tem como instrumento possíveis paralisações dos serviços prestados, pouca produtividade ou boicote à atual política de segurança pública, contribuindo para o fluxo político ou fluxo do problema, que foram debatidos nas seções anteriores.

Já no caso das associações representativas da Polícia Militar, que não tem o direito de induzir os policiais militares para a não produção de serviço ou para a paralisação das atividades policiais, há também a produção de propostas que têm como foco a garantia de direitos individuais dos policiais militares e a manutenção dos valores tradicionais da instituição. A Associação de Oficiais da Polícia Militar do Distrito Federal (ASOF/PMDF), por exemplo, é uma associação representativa de todos os oficiais da instituição que tem em seus objetivos atuar junto ao poder estatal, através de ações na esfera administrativa ou judicial em defesa aos interesses comuns de seus associados, há também o objetivo da associação de 
[...] colaborar com as autoridades constituídas e outras entidades, no sentido de promover encontros, seminários, congressos, cursos ou outros eventos entre a sociedade civil e as instituições públicas e privadas, para a discussão de políticas públicas e diretrizes de interesse da associação (ASOF, 2014)

Nesse sentido, para a ASOF/PMDF, há como premissa em seus estatutos o debate, a proposição de políticas que contribuam com a sensação de segurança e manutenção da ordem social. Destaco a relação com a ordem social estabelecida porque, como demonstrado no texto destacado acima, é uma luta trabalhista que produz discursos para produção de políticas públicas que estejam de acordo com as diretrizes e interesses da associação que defende os direitos e interesses dos oficiais da PMDF.

O exemplo das associações das duas principais agencias de segurança do Distrito Federal demonstra como que a luta por direitos conquistados e por demandas trabalhistas podem colaborar para o fluxo da soluções de políticas de segurança pública. Ter uma polícia única, ciclo completo ou outras soluções com o intuito de trazer ao debater o aumento da eficácia e da eficiência da ação policial são alguns exemplos de soluções que são construídas fora das associações representativas das agências de segurança e que, de alguma maneira, podem alterar prerrogativas institucionais construídas pelas categorias de profissionais e, portanto, estes representantes produzem discursos tradicionais ou científicos para tentar legitimar a manutenção dos direitos trabalhistas e a forma de atuação de cada agência.

Se a SENASP/MJ apresenta suas soluções com um fomento financeiro para atrair a maior quantidade de agentes de segurança pública e de Estados e Municípios, as soluções das associações representativas são acompanhadas por uma possível legitimidade interna dos agentes, ou a resistência interna quando as soluções internas são apresentadas e ameaçam o que entendem por direitos e prerrogativas constituídas.

Além das associações, algumas lideranças das categorias profissionais atuam em outras arenas, como representantes no poder legislativo, apresentando soluções para as demandas sociais que envolvam a temática ou promovendo o debate público sobre a questão, auxiliando na exposição dos problemas sociais em segurança pública e, ao mesmo tempo, constroem estratégias políticas que garantam o que percebem como direitos adquiridos e busca por conquistas para a categoria e para a carreira política que 
ingressaram ao sair das instituições de origem, seu espaço de construção da base eleitoral. Nesse contexto, as soluções sobre segurança pública e privada entram no cenário partidário e propostas acadêmicas misturam-se com propostas trabalhistas dos agentes de segurança pública e dos agentes de segurança privada nas comissões temáticas e nas audiências públicas com representantes legislativos, ora assessorados por acadêmicos/técnicos, ora assessorados por agentes de associações das categorias.

Todavia, as soluções que compõem o fluxo não se esgotam em instituições de controle social do Estado ou em seus representantes. Há também Institutos, associações ou organizações não-governamentais que desenvolvem propostas de políticas de segurança pública como, por exemplo, o Instituto Cidadania, que desenvolveu o projeto Segurança Pública para o Brasil em que enumera uma série de ações, priorizando a ação das agências de controle como solução a curto prazo para algumas questões que o Instituto identificou como problemas (drogas, sequestro, controle externo da atividade policial, violência doméstica e de gênero, sistema penitenciário, entre outras). Neste plano, há a proposta de criação de uma rede e de um centro de referências para proteção das minorias sociais (étnicas, gênero, e geracional). Mesmo com esta complexidade de ações que pode revelar uma análise de causa efeitos e possíveis grupos vulneráveis, o foco das propostas está ainda em soluções que propõem políticas de segurança pública.

Há ainda aqueles atores que propõem políticas públicas que podem influenciar o campo da segurança pública. O Instituto Não à Violência, por exemplo, tem como missão "desenvolver e fortalecer uma cultura da paz por intermédio da escola". O Instituto se propõe a ser uma "referência nacional e multiplicadora de metodologias eficazes para fortalecer a cultura da paz" (INSTITUTO NÃO A VIOLENCIA, 2014). Para tanto, propõe que a Escola seja a protagonista das ações para o estabelecimento de uma cultura de paz na sociedade e que, ao contrário das outras propostas, a comunidade escolar que são os executivos de tais políticas públicas com o intuito de diminuir os diversos tipos de violências.

Portanto, o fluxo de soluções para a segurança pública foi composto por vários atores com diferentes percepções. Para o recorte do estudo do nosso objeto de pesquisa, foi percebido que uns privilegiaram o discurso conservador e as tradições institucionais das agências de segurança pública, outros discursos racionais privilegiaram o debate científico e a inovação na prática dos executivos da segurança pública e das agências. Uns apresentaram como ator principal das propostas os agentes e instituições de segurança 
pública, outros, destoando desta percepção, apresentaram diferentes membros da sociedade civil como protagonista para a diminuição da violência e da criminalidade. Alguns propõem a ação dos próprios atores em rede, outros, a ação de forma isolada privilegiando o monopólio do conhecimento sobre segurança pública. Os atores governamentais (políticos, servidores conservadores e/ou defensores o Estados) e os atores não governamentais (organizações de pesquisas, associações, partidos políticos) incrementaram às suas propostas de políticas públicas diferentes instrumentos de convencimento como, por exemplo, capital político para as eleições ou para aprovações de outras matérias na Câmara Legislativa, capital social para liderar na aceitação e condução de políticas públicas, programas e ações do governo pelos agentes de segurança pública, ou capital acadêmico para legitimar as ações com dados científicos/racionais, entre outros dispositivos. 


\section{CAPÍTULO 2 O PONTO ÍGNEO DA AGENDA DE SEGURANÇA PÚBLICA}

Como apresentado no quadro teórico dos múltiplos fluxos, o processo pode se iniciar em setores de pesquisa e análise criminal, (instituições acadêmicas ou setores estratégicos e estatísticos da Polícia Militar, da Polícia Civil ou da Secretaria de Estado da Secretaria de Segurança Pública); podem ser sugeridas alternativas como políticas públicas às instituições responsáveis (Detran, Polícia Militar, Polícia Civil, Departamento de Estrada e Rodagens, entre outras); após análise, os gestores podem reinterpretar essas orientações e reformular as políticas públicas e, após a reinterpretação, implementar a política. Nestes casos, originaram-se dentro da própria instituição.

Em outros casos, as políticas são impostas por decisões políticas superiores hierarquicamente, como uma decisão do Governador do Distrito Federal ou do Secretário de Segurança, e os gestores não têm uma margem de interpretação e "devem" implementar a política da forma em que foi constituída.

Assim, a consequência lógica que pode ser utilizada por alguns dos atores (político, acadêmico, destinatário das possíveis políticas) resultante dessas teses é que a criminalidade está diretamente associada à falta de políticas públicas que reduzam a pobreza, a miséria, a marginalidade, a força migratória, mesmo que não haja consenso na comunidade acadêmica ou em outros segmentos do Estado (Secretaria de Direitos Humanos, por exemplo) quanto às causas da criminalidade e do desvio.

Filho (1999) lembra que em outros momentos as políticas de segurança pública que não estivessem vinculadas à ação policial são percebidas como assistencialistas por alguns setores do sistema de segurança pública. Seriam as políticas de segurança que compõem programas sociais versus programas repressivos. Assim, para determinados setores, políticas de segurança são ações de combate que redunda em prisões e em apreensões de entorpecentes, de armas e/ou de objetos furtados/roubados; em outros grupos, há o entendimento que políticas de prevenção, de redução de risco como, por exemplo, a distribuição de seringas e de drogas com menor poder ofensivo, seriam políticas de segurança pública, neste caso, ela estaria mais alinhada à filosofia de policiamento comunitário. 
A proposição de políticas públicas de segurança, no Brasil, consiste em um movimento pendular, oscilando entre a reforma social e a dissuasão individual. A ideia da reforma decorre da crença de que o crime resulta de fatores socioeconômicos que bloqueiam o acesso a meios legítimos de sobrevivência.

Mas o que cabe destacar neste momento é: o que origina a política de segurança pública? Quando há convergências dos fluxos? A convergência dos fluxos (policy Windows) são influenciadas principalmente pelo fluxo de problemas e pelo fluxo político. Segundo Capella (2006:95)

\begin{abstract}
Ao tomarem conhecimento de um problema, os formuladores de políticas acionam a policy stream em busca de alternativas que apontem soluções para o problema percebido. Da mesma forma, ao encampar determinadas questões em suas propostas de governo, políticos buscam alternativas nas policy communities.
\end{abstract}

Ainda segundo a autora (CAPELLA, 2006:98), da mesma forma que os momentos de convergências do fluxo permitem uma janela de oportunidade para a formulação e reconhecimento de uma política pública para um determinado problema, estes momentos se fecham. Neste espaço, é importante reconhecer a ação dos empreendedores de políticas, atores visíveis (Presidente, governadores, os membros do poder executivo, a mídia com menor poder de mobilização, entre outros) e participantes invisíveis que tentam criar janelas de oportunidades. Tanto os atores visíveis quanto os atores invisíveis estimulam e difundem alternativas, mas também podem dissuadir e desestimular a escolha de determinadas alternativas.

No caso das políticas de segurança pública, a comunidade formuladora de políticas, que tende a monopolizar a policy image, agrega especialistas funcionários de instituições tradicionais distintas (Polícia Civil, Polícia Militar, Corpo de Bombeiro Militar e Detran) como foi demonstrado.

Nesse sentido, Garland (2001) está preocupado com as interações entre as agências que, de uma forma ou de outra, contribuem na formulação do controle da criminalidade e do delito, e, assim, da política de segurança pública. O autor evidencia a relação histórica das instituições, dos discursos e as ações institucionalizadas para controlar o delito. Perceber as mudanças sociais e, por conseguinte, as fontes desta mudança (axiomas, sensibilidades culturais, entre outros) são essenciais para compreender o campo de controle de delito e os processos que auxiliam na formulação 
de soluções e, por conseguinte, na formulação e implementação das políticas de segurança pública.

Como o campo de controle do delito (Garland, 2001) apresenta uma diversidade de agências complexas e singulares (sistema policial, sistema judiciário, sistema penitenciário, entre outros), pontuaremos a nossa discussão nas instituições policiais, especificamente na Polícia Militar do Distrito Federal, mas sem perdermos a percepção de que essas instituições fazem parte de um campo que, por sua vez, faz parte de um conjunto de pressupostos que podem ser comuns a toda a sociedade ou por um grupo dominante (econômico, político e/ou religioso, por exemplo).

Como foi apresentado nos dados anteriores, o fluxo de problemas apresentou indicadores bem anteriores ao início da formulação da política pública. O Distrito Federal manteve uma taxa de homicídio constantemente superior à do Brasil. Outros crimes também tiveram características semelhantes com elevadas taxas. Assim, somente os indicadores não conseguiram estimular o processo linear de apresentação de um problema, atuação dos atores políticos e apresentação de soluções.

Se o fluxo dos problemas não conseguiu sozinho estimular a formação da agenda de segurança pública, os atores políticos também não tinham o interesse em propor ações voltadas para o debate. A agenda de política de segurança pública no Distrito Federal, como apresentado anteriormente, tem um espaço pequeno para ser debatida na arena política. Como foi salientado, a segurança pública não transitava como prioridade no cenário político local principalmente porque, no decorrer dos mandatos do poder executivo, isso não foi percebido como um problema para ser elencado como uma prioridade que supere, por exemplo, a atenção dada aos problemas questões referentes à saúde pública.

Assim, são raros os momentos em que as políticas de segurança público ou os programas institucionais para diminuir a criminalidade ganham notoriedade durante os mandatos do governo do Distrito Federal. Todavia, há um momento específico em que a confluência da percepção dos indicadores de criminalidade (fluxo dos problemas), aliase a possíveis respostas racionais (fluxo das soluções) com a aderência política acontece, é o momento anterior às eleições.

É neste espaço-tempo que a maioria dos temas percebidos como sensíveis são debatidos pelas equipes organizadas que foram estruturadas pelas coordenações de campanha para apresentarem à sociedade programas de governo. Alguns temas são 
recorrentes como, por exemplo, a saúde pública, a educação pública e a segurança pública. Muitas vezes outros temas, como o sistema de transporte coletivo e os transportes alternativos, a questão ambiental e o desenvolvimento de políticas para o fomento da indústria local também ganham espaço e consultores compõem estas equipes. As equipes são formadas por consultores, especialistas ou servidores públicos que trabalham na temática por estarem lotados nos setores estratégicos sobre os temas.

\subsection{A Proposta Construída em Período das Eleições}

Os dados que serão apresentados são fruto das entrevistas de dois policiais militares chaves para este processo: Oficial $1^{18}$ e Oficial 2. Conheci estes dois policiais após a entrevista com o Capitão da PMDF Oficial 3, então Coordenador Nacional de Polícia Comunitária da Secretária Nacional de Segurança Pública (SENASP) do Ministério Justiça (MJ), que indicou o Oficial 1 como um especialista, e que havia participado da equipe que formulou a política pública Segurança Comunitária no DF. Este, por sua vez, indicou o Oficial 2, então o coordenador do núcleo da equipe que elaborou o projeto da política de segurança pública que instalaria os conhecidos postos de segurança para a equipe de campanha eleitoral de 2006 do então candidato ao Governo do Distrito Federal José Roberto Arruda.

A produção dos dados para esta parte da pesquisa seguiu essa sequência, em momentos diferentes. Primeiro foi realizada a entrevista com o Oficial $1 \mathrm{em}$ sua residência porque acabara de realizar uma cirurgia. Além de ser autodidata, concluiu vários cursos sobre o tema. O policial fez viagens de estudo para diversos lugares no oriente como, por exemplo, para a Oceanaia, além de trabalhar em missões de paz em alguns países, todavia, foi em sua viagem de férias, na Austrália, que teve contato com o Policiamento Comunitário de forma sistematizada.

\footnotetext{
${ }^{18}$ Mesmo com a autorização dos policiais militares para a publicação dos nomes, optamos por ocultar como uma forma de garantir a proteção que possíveis desdobramentos dos debates podem ter nas relações políticas e profissionais dos entrevistados.
} 
Foi na Austrália que, durante viagem de lazer, participou de reuniões sobre a segurança local com representantes da polícia, moradores, comerciantes, representantes de associações, entre outros. Fez um curso de segurança pública que, aliás, é quase prérequisito para a participação nas reuniões porque debate conceitos e metodologias que são instrumentalizados nas reuniões. O oficial teve dois estranhamentos: primeiro, o curso sobre segurança pública pôde ser frequentado por um estrangeiro que saberia como são os procedimentos policiais, quantidade do efetivo policial e equipamentos. O que na cultura policial brasiliense é um segredo para "garantir" a segurança pública, neste outro espaço há o compartilhamento de informação.

$\mathrm{O}$ segundo estranhamento refere-se a quem pode participar das reuniões e a prerrogativa para tal participação. Segundo o oficial da PMDF, bastou que ele falasse que era policial no Brasil e que tinha interesse no tema. Não houve a necessidade de apresentar documentos de identificação ou da instituição brasileira solicitando sua participação.

[...] na Austrália eu fiz um curso de uma semana que foi um curso que mudou minha forma de conhecer Segurança Pública, que é um curso de Prevenção Criminal e Defesa Ambiental - o que o curso ensinava? Quais foram os instrumentos que me deram nesse curso? Você tem a relação espaço e Segurança Pública, então que alterações você pode fazer no espaço pra que você possa reduzir as oportunidades pro crime, por exemplo? Então nesse curso que eu fiz na Austrália de uma semana tinha representantes comunitários; tinha agentes da prefeitura; o cara da companhia de energia; segurança de hospital; membros das Forças Armadas; policiais e eu estava lá como estrangeiro convidado. Aí a gente estudou todo conceito de defesa ambiental, quais os instrumentos pra você fazer um bom diagnóstico e como você vai responder esse diagnóstico - em um dia a gente sai com trabalho de campo, a gente foi pra uma praça e fez o diagnóstico dessa praça, os grupos né, nós identificamos os problemas e fizemos as proporções das respostas e aí no último dia a gente fez o seminário para poder apresentar os nossos achados e tudo mais né? [...]

Destaco essas informações porque a experiência pessoal do policial lhe forneceu dois elementos cruciais: que a segurança pública não tem nacionalidade, envolve todos os indivíduos que estão no espaço, independente da sua "apropriação do local" porque afeta a todos; e a corresponsabilidade da segurança pública que envolve as agências policiais e a sociedade civil, condição para a atividade do policiamento comunitário, também é compartilhamento de determinadas informações e ações, o que demonstra também confiança entre os envolvidos, demonstra o reconhecimento do outro.

A segunda entrevista sobre o processo de formação da agenda e formatação da política pública foi indicada pelo Oficial 1, com o Oficial 2. Realizada alguns meses 
depois da indicação, entre uma assinatura de documento e outro, entre despachos com subordinados e saídas para reuniões com os superiores, o ambiente foi a Seção de Planejamento e Projetos no Estado Maior da PMDF, local que reencontrei o Oficial 1 trabalhando quase recuperado da cirurgia.

Foi a partir destas entrevistas que pude reconstruir o tempo da formatação da proposta de política pública na área de segurança que se concretizou no Programa de Segurança Comunitário do Distrito Federal, em que a Segurança Pública local ganhou espaço para debate na equipe que formulava propostas de campanha para o então candidato José Roberto Arruda.

Segundo o Oficial 2, já havia a proposta política da implantação de 300 postos feita por José Edmar, candidato a reeleição a deputado distrital que era do partido da coligação. Assim, já havia uma decisão política do grupo de candidatos para a instalação de 300 (trezentos) postos policiais em todo o Distrito Federal, que foi acatada pelo candidato ao governo como proposta de campanha para a segurança pública.

O número percebido como emblemático pela equipe não tinha explicação técnica e sim como um elemento para a campanha. Para o candidato a deputado, havia uma concentração de policiais e a instalação de trezentos postos descentralizaria o efetivo policial militar e tornaria os policiais mais próximos. Não havia metas, problemas, objetivos para ser solucionados, estimativa de custo ou qualquer categoria própria das políticas públicas. Segundo os interlocutores entrevistados, houve apenas a preocupação em estabelecer um impacto político na população pelo número de postos e, assim, a de criar a expectativa na população que teria a implantação de um posto policial próximo a residências.

As palavras do então Oficial 2 que trabalhou no processo de transição revela um pouco dos bastidores deste processo

Virou um slogan de campanha como um produto do mercado do voto $[\ldots]$

Promete-se tudo, depois vemos como é que faz, faz parte da cultura política partidária [...]

O deputado e a equipe política não sabiam como fazer e, segundo o Oficial 2, durante a campanha, nos debates políticos que eram televisionados, havia o 
questionamento sobre a viabilidade da proposta e até o momento a Coligação liderada por José Roberto Arruda não tinha respostas para tais questões.

A proposta de segurança pública que era para ser um fator positivo, começou a ser visto como algo negativo para a campanha, por não ter um visibilidade de concretização da implantação.

\begin{abstract}
"quando a coisa fica feia e não se resolve politicamente, chama o técnico que ele resolve, e nós conseguimos dar algumas respostas"
\end{abstract}

Após o processo eleitoral, com a vitória de José Roberto Arruda para o Governo do Distrito Federal, entre várias outras metas apresentadas na campanha de eleição, havia a promessa de instalar os 300 (trezentos) postos. Segundo os entrevistados, a solução encontrada e recebida pela população deveria sair da esfera política para ganhar conteúdo técnico. Para tanto, outras ações foram organizadas pela equipe de transição e uma equipe específica foi montada para tal fim, ou seja, planejar a instalação dos postos.

O Oficial 2 entrevistado gosta de ser chamado de um técnico, não de especialista. Segundo o tom de sua fala, ser técnico é ser comprometido com os critérios da ciência e com a racionalidade, o que é próprio de quem trabalha com planejamento. Já especialistas podem ter vocações políticas. Assim, segundo o oficial, todas as suas escolhas passariam por decisões técnicas. Esta correção foi realizada como um tentativa de manter suas ideias e convicções imaculadas, mesmo que estivessem em uma arena política que fomentava suas ações e a própria escolha para ser parte de um grupo de campanha a eleição a governador como coordenador de uma equipe.

A equipe foi montada pelo Oficial 2 para desenvolver trabalho técnico de construção da proposta do candidato ao governo. A escolha desse coordenador, segundo o próprio oficial policial, é porque tem o poder de aglutinar pessoas com a expertise necessária para o "bom andamento do serviço"19. Considerada pelo coordenador como uma equipe numerosa e com grande conhecimento na temática, o grupo foi escolhido pelo

\footnotetext{
${ }^{19}$ Dar um "bom andamento no serviço" é uma expressão utilizada pelos policiais militares do Distrito Federal para demonstrar que o serviço não tem interrupções por questões burocráticas ou operacionais. É tão recorrente esta expressão que, em alguns sanções administrativas, há o argumento que determinado policial militar está sendo punido por atrapalhar o bom andamento do serviço, seja por apresentar requerimentos de forma reiterada que, segundo os gestores, não tem direitos, seja por atrapalhar de alguma forma ações ou operações policiais.
} 
conhecimento técnico, sendo composta por policiais militares praças e oficiais, entre eles outros dois majores.

A equipe foi dividida por assuntos de pesquisa que subsidiariam o projeto final. Assim, alguns ficaram responsáveis para realizar levantamentos socioeconômicos da comunidade, realizar a análise criminal das cidades administrativas do DF, analisar as características urbanas como, por exemplo, a densidade demográfica, se é tipicamente uma cidade horizontal ou preponderantemente uma cidade vertical. Também analisaram as modalidades de policiamento possíveis com o nova prática policial.

O projeto final teve como sugestão de política pública a implantação do Programa Comunitária de Referência Social (PCRS). Com mais de 220 (duzentos e vinte) páginas, é composto por vários documentos de análise e minutas de convênio, com várias referências teóricas e dados. Inicia debatendo os dados das pesquisas de opiniões sobre a PMDF realizadas no ano de 1997 e 1998 pela Universidade de Brasília ${ }^{20}$. Segundo a interpretação que fizeram dos dados da pesquisa, a população, para este grupo, entende que os policiais militares necessitam reorientar as suas práticas para o melhor atendimento à população e, para tanto, têm que ter mudança na formação e qualificação policial, em todos os níveis hierárquicos.

Outra menção importante a ser considerada no texto é quanto às ações de fomento do Governo Federal para mudar as práticas policiais nas unidades federativas. O Plano Nacional de Segurança Pública editado em 2000, no governo do então presidente Fernando Henrique Cardoso e continuado no governo do então presidente Luís Inácio Lula da Silva, também são alguns dos elementos constitutivos do escopo do projeto. Para tanto, os autores do projeto lembram que nas entrelinhas do Programa Nacional de Segurança Pública há a preocupação do Governo Federal no distanciamento das instituições policiais, e principalmente dos policiais militares, com a população brasileira e apresenta como uma possível solução federal o incentivo à adoção do modelo do policiamento comunitário nas unidades federativas.

Como objetivo inicial da proposta de política de segurança pública para prestar um "serviço de excelência no atendimento social comunitário", há seis pontos no projeto:

- Prevenir o crime com base na comunidade;

- Enfatizar os serviços não emergenciais;

\footnotetext{
${ }^{20}$ Segundo o Projeto, os dados primários estavam em DATA - UNB. Pesquisa de Opinião sobre a
} atuação da Polícia Militar do Distrito Federal: Brasília: UNB, 1998. 
- Aumentar o sentimento de responsabilidades pela prevenção do crime na sociedade e nos agentes de segurança pública, os policiais militares;

- Descentralizar o comando, para que os comandantes locais tenham mais liberdade e velocidade nas adaptações necessárias em cada bairro ou localidade;

- Avaliar relatórios para produção de dados ao serviço de inteligência e para reorientações devidas; e

- Supervisão e fiscalização.

Esses objetivos são fruto de uma discussão do grupo a partir das produções teóricas de pesquisadores como, entre outros, Bayley \& Skolnick (2001 e 2002) e Paulo Mesquita Neto $(1998)^{21}$. Para o grupo, os objetivos da política pública retratam a possibilidade do policiamento comunitário real no Distrito Federal como uma polícia de aproximação. Portanto, uma análise a partir das experiências apresentadas pelas obras dos autores reconhecidos no campo científico academia possibilitaria a construção de projeções contextualizadas regionalmente que seriam concretizadas no projeto.

Todavia, a pesquisa de Neto auxiliou o grupo a inferir os possíveis problemas no processo de implementação. Não distante da literatura internacional, mas versando sobre o oficialato de uma Polícia Militar do Brasil, os estudos de Neto demonstraram como há fatores internos e externos que dificultam o processo de implantação do modelo de policiamento comunitário. Percebida como uma forma de policiamento e, em muitos casos segregado, a gestão organizacional também foi objeto de preocupação do grupo.

Após o tempo em que as percepções construídas fossem mediadas pelas leituras desses estudos, o projeto apresentou as seguintes diretrizes para serem seguidas:

1 - Criar um Grupo de Alta Gestão do Programa Comunitário de Referência Social (PCR), subordinado diretamente ao Governador do DF, com o objetivo de: Criar e implementar as Diretrizes do Programa Comunitário de Referência Social; Criar e implementar na estrutura da Secretaria de Segurança e Cidadania os Conselhos de Segurança e Cidadania, sediados em cada Região Administrativa, na estrutura organizacional de cada Administração Regional; Acompanhar e avaliar sistematicamente o PCR;

\footnotetext{
${ }^{21}$ Em estudo intitulado Policiamento Comunitário e Prevenção do crime o pesquisador Paulo de Mesquita Neto, do Núcleo de Estudos da Violência da Universidade de São Paulo, analisou a percepção dos Oficiais superiores da Polícia Militar de São Paulo acerca do tema. Dificuldades de implantação
} 
2 - Sediar os Conselhos de Segurança e Cidadania nos quarteis da PMDF, desenvolvendo ações de prevenção primária dirigidas às famílias de jovens em situação de risco social;

3 - Mapear os processos administrativos da PMDF, por meio de equipes técnicas;

4 - Racionalizar os processos administrativos da PMDF, utilizando-se dos recursos tecnológicos existentes;

5 - Implementar o serviço voluntário civil;

6 - Promover palestras a respeito do PCR;

7 - Promover treinamento do pessoal envolvido no Programa de Referência Social; e

8 - Disponibilizar o banco de dados de análises criminais para os presidentes dos Conselhos de Segurança e Cidadania.

Como destacado anteriormente, as diretrizes formuladas foram influenciadas pelos estudos dos autores citados, e em parte considerável do projeto há a menção sistemática dos autores como que para legitimar cada proposta ou sentença. Todavia, a contextualização e a tentativa de inovar ao mesclar serviços que antes eram tipicamente policiais (controle dos conflitos e desvios) com serviços prestados por outras instituições é uma releitura da literatura internacional.

Serviços que eram prestados pela Polícia Civil, como o caso da lavratura do Termo Circunstanciado de ato de menor potencial ofensivo, ou a mediação de solicitação de serviços públicos são algumas das atribuições que o projeto contemplava como próprios do policial militar que trabalharia postos policiais, os agentes de segurança e cidadania.

Os policiais militares de serviço nos postos deverão manter contatos com as pessoas da comunidade local e com os comerciantes nos seus afazeres e itinerários diários dentro dos seus respectivos horários de serviço, com lançamento em relatórios e formulários próprios para análise criminal; registrarão as mudanças de endereço, além dos nascimentos e das mortes do bairro, e outras atualizações necessárias, incentivarão os pedidos de serviço preventivos para diminuição dos emergenciais, facilitando os atendimentos de urgência, os quais se darão com menor número de efetivo e viaturas. Dessa forma, será liberado mais efetivo do patrulhamento motorizado para o atendimento social. Farão, também, a intervenção no estágio inicial dos problemas, desenvolvendo um sentimento de responsabilidade social em relação a segurança pública; explicarão os serviços da Polícia Militar com mais tempo e precisão, obterão informações que levarão a prisão de criminosos e malfeitores; implementarão o atendimento nos casos de infração de menor potencial ofensivo, previstos na Lei 9099/95, executando a lavratura do Termo Circunstanciado no Posto de Segurança e Cidadania, otimizando o serviço de 
segurança estatal, minimizando o tempo de deslocamento as delegacias, como é o modelo atual. Como resultado, desafogarão as Delegacias, para que possam concentrar esforços na investigação das infrações penais de maior potencial ofensivo e lavratura de Auto de Prisão em Flagrante. Nos PSC deverão ser executados os seguintes serviços: recebimento de denúncias; solicitações de serviço; achados e perdidos; aconselhamento de segurança pública; palestras; e, ligação e encaminhamento para os serviços de atendimento social do estado. (FEITOSA et all, 2006:19)

O serviço policial militar rotineiro que concentra esforços em combater o crime, em uma perspectiva belicista, teria cumulativamente algumas atribuições que eram dos agentes da Polícia Civil, realizar visitas comunitárias às vítimas e estabelecer contatos sistemáticos com os comerciantes locais. Além disso, realizariam palestras à comunidade local com o intuito de aproximar as relações com os moradores e seria mais uma forma para elucidar à comunidade quais são as responsabilidades da Polícia Militar.

Para tanto, entre as diversas formas de policiar, chamada de modalidade de policiamento $^{22}$ pelos policiais militares, a escolhida pela equipe de planejamento seria $\mathrm{o}$ policiamento a pé. Esta predileção se daria porque poderia dar maior sensação de segurança à população e uma sensação de maior presença do Estado. Segundo o projeto, entre as ações típicas de policiamento que esta modalidade de policiamento evitaria seriam as pichações em espaços públicos, os cumprimentos de pequenas regras, vandalismo, mendigos pela rua, crianças de rua, bebedeiras em público, música alta (FEITOSA e all, 2006:20).

Para que esse trabalho fosse realizado, o projeto contemplava unidades do PCR que seriam os Postos de Segurança e Cidadania (PSC). Cada posto teria uma sala de atendimento ao público em geral; sala de reconhecimento com dispositivo de detenção momentânea; sala de monitoramento do CFTV (Circuito Fechado de TV) e radiocomunicação; sala de comando e atendimento reservado destinada ao comandante do posto; banheiros para os policiais militares, para os cidadãos atendidos e um banheiro para pessoas com necessidades especiais; sala de material; sala de descanso; copa; sala de múltiplas funções, com capacidade para reunir trinta pessoas, que, segundo o projeto, seria um verdadeiro ponto de referência para a comunidade do bairro. A figura abaixo é um recorte da planta baixa anexada ao projeto que ilustra a disposição das salas e das possíveis interações no mesmo espaço.

\footnotetext{
${ }^{22}$ Modalidade de policiamento para a PMDF é como o policial militar se locomove no espaço de responsabilidade para realizar o policiamento. Portanto, as modalidades de policiamento podem ser a pé, a cavalo, motorizado por veículos quatro rodas, duas rodas, por lancha, ou aeronaves.
} 
Figura 2 Postos de Segurança e Cidadania

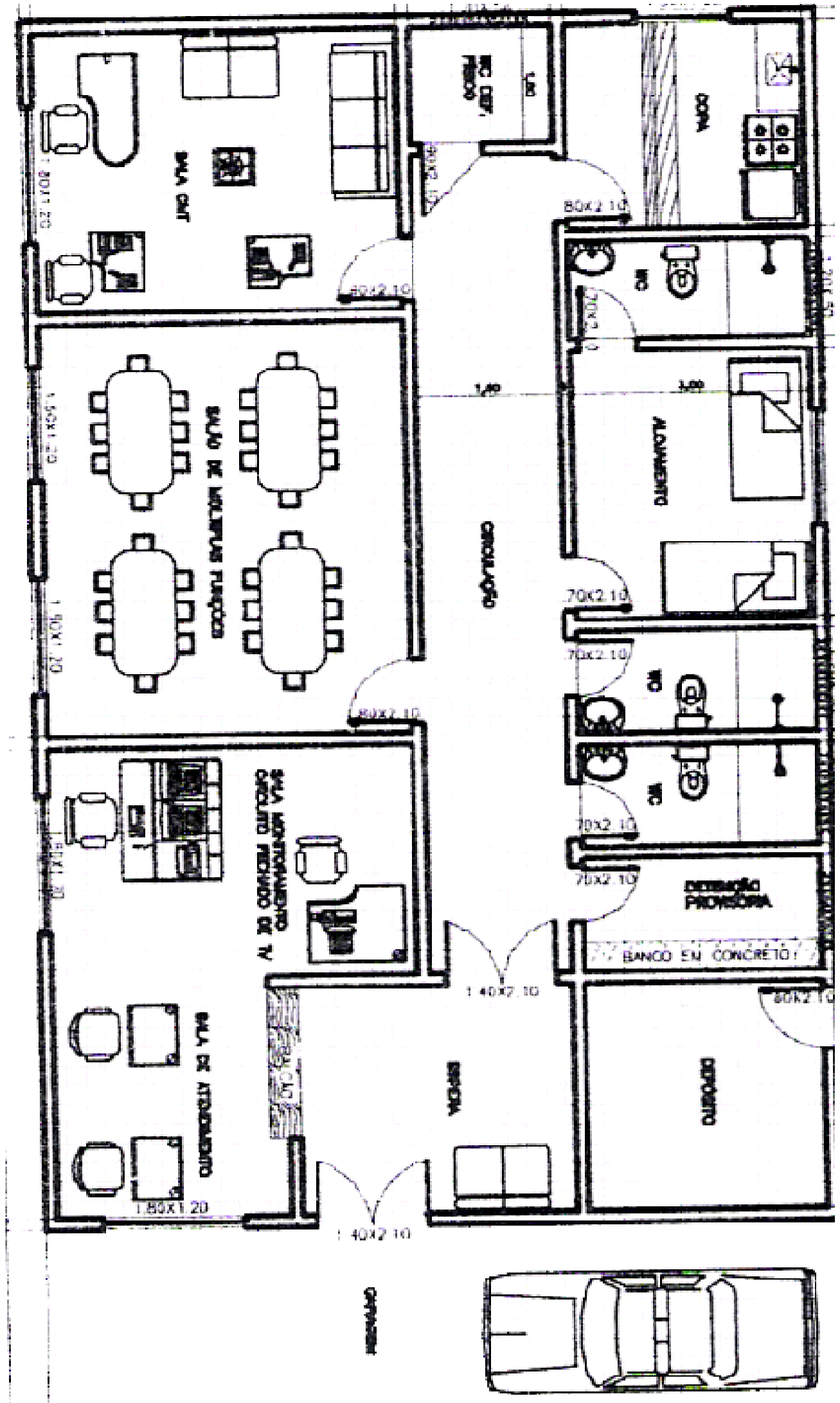


O projeto contemplava todos os recursos mobiliários e com orçamento para cada unidade policial do PSC. O detalhamento dos recursos iam dos recursos para serviços administrativos (armários, grampeadores, quadro de avisos, entre outros), para o atendimento na própria unidade (aparelhos telefônicos, cafeteira, computadores, entre vários outros), para as reuniões (mesas, cadeiras, projetores multimídias), para o acolhimento policial (cofre, beliches, frigobar) e para o patrulhamento e atendimento domiciliar ou em vias públicas (binóculo, lanterna, um automóvel, duas motocicletas, duas bicicletas, entre vários outros recursos modificados ou caracterizado para a ação policial), totalizando mais de trinta itens por unidade. O custo de todo o mobiliário estava estimado em $\mathrm{R} \$ 32.341,00$ (trinta e dois mil, trezentos e quarenta e um reais).

A construção de cada PSC estava estimada em R \$ 60.000,00 (sessenta mil reais). A referência que o grupo utilizou foi a construção de um posto rodoviário da então Companhia de Polícia Rodoviária da PMDF que custou R \$30.000,00 (trinta mil reais) para uma área construída que seria a metade da unidade projetada de $150 \mathrm{~m}^{2}$.

$\mathrm{O}$ custo para a realização de atividades administrativas estava estimado em $\mathrm{R} \$$ 4.499,80 (quatro mil, quatrocentos e noventa e nove reais e oitenta centavos). Esse material seria para o atendimento à comunidade local e para as ações administrativas.

O valor total de cada Posto de Segurança e Cidadania (PSC) do Programa de Comunitário de Referência Social teria um custo estimado em R \$ 96.840,80 (noventa e seis mil, oitocentos e quarenta reais e oitenta centavos), sem considerar o equipamento próprio do policial como, por exemplo, uma arma de porte individual (pistola .40), tonfa, algema, clava química, colete balístico e HT, os necessários para controle de trânsito, visores noturnos, binóculos, palm tops, entre outros.

A manutenção e limpeza dos PSC estava contemplado no projeto por um convênio com o Banco de Brasília, instituição pública financeira do Distrito Federal. Entre os documentos produzidos pela equipe para projeto do PCR, havia uma proposta de convenio entre o GDF e o Banco de Brasília (BRB) que estabelecia a parceria entre as partes para instalação de caixas eletrônicos de autoatendimento do banco regional e, como contrapartida, a instituição financeira ficava responsável pelos serviços de limpeza nos Postos de Segurança e Cidadania, assim como as pinturas a cada 06 (seis) meses. A minuta de convênio contemplava os 300 (trezentos) postos.

Quanto ao planejamento da atuação policial, havia a previsão de 30 (trinta) policias para cada PSC. Seriam 04 (quatro) sargentos, 07 (sete) cabos e 19 (dezenove) 
soldados. A distribuição destes seriam para montar as várias equipes de atendimento. $\mathrm{O}$ projeto contemplava gozo de férias, abonos e folgas no decorrer do ano. Este controle seria realizado pela unidade policial operacional, os Batalhões já existentes, todavia, havia um modelo de escala de serviço com seis equipes no projeto para todos os dias do mês.

As escalas de serviço seriam feitas mensalmente por equipe. Esta não é uma prática nas unidades policiais militares da PMDF porque há solicitações diárias provenientes de várias instituições (Ministério Público, escolas, igrejas, associações, entre outros), as escalas são feitas quase que diariamente para atender as demandas locais e remanejar efetivos policiais. Dessa forma, fazendo as escalas mensalmente, os policiais focariam suas atividades para o atendimento comunitário local. O serviço policial continuaria tendo a carga horária de 12 (doze) horas para cada turno.

A rotina diária também estava planejada para um de mínimo de dez ações:

1. Sempre teria dois policiais para o atendimento diário à população no PSC e dois policiais exclusivamente para realizarem patrulhamento. $\mathrm{O}$ policiamento a pé, em motocicletas ou em bicicletas, seria um acréscimo de modalidade policial, principalmente nas áreas comerciais locais;

2. Ao iniciar o serviço, os policiais deveriam realizar patrulhamento para estabelecer contatos com os moradores e comerciantes;

3. Após o estabelecimento de contatos, os policiais deveriam posicionar as viaturas próximas às escolas, em pontos de demonstração preestabelecidos pelas esquipes para acompanhar as entradas e saídas dos alunos nos períodos matutino, vespertino e noturno;

4. Depois, deveriam realizar rondas constantes nas áreas comerciais e conversar com os comerciantes com o intuito de saber se houve ocorrências não relatadas ou registradas oficialmente;

5. Também deveriam estabelecer contatos com moradores para obter informações pertinentes ao serviço policial, principalmente para averiguar se houve qualquer tipo de anormalidade local;

6. Sempre teria a obrigação de manter no mínimo dois policiais no PSC para atendimento;

7. No final da tarde, os policiais deveriam realizar patrulhamento no comércio local até o fechamento dos estabelecimentos comerciais; 
8. Durante a mudança de equipe, ao final do serviço, os policiais militares deveriam informar aos policiais que iniciassem o turno seguinte de trabalho quais as ocorrências e informações pertinentes para o exercício das atividades de policiamento comunitário;

9. Também já estava contemplada a lavratura do Termo Circunstanciado. Assim, todos os crimes de menor potencial ofensivo seriam registradas no próprio PSC em documento próprio, de acordo com a lei dos juizados especiais (Lei 9.099/95), e

10. Os policiais deveriam encaminhar ao comando local todos os Termos Circunstanciados para que fosse remetido pelo comandante da unidade policial ao Juiz competente.

Além dessas ações obrigatórias, há outras tarefas que, no projeto, são percebidas como próprias das atividades dos policiais militares dos PSCs, entre elas estão: realizar palestras periodicamente para a comunidade; e quando receber solicitação da comunidade que não fossem próprias da atividade de policiamento, enviá-la ao comando para que fossem tomadas as medidas pertinentes; confeccionar relatórios, entre outros.

Como um dos pontos debatidos sobre a pesquisa de opinião foi relativo à formação policial e por ser uma outra forma de policiar, segundo o Oficial 1 e o Oficial 2 Feitosa, um dos volumes do projeto era referente à proposta de formação policial.

No segundo volume do projeto há a apresentação do Curso de Policiamento Comunitário (CPC) que tinha como objetivo

Dotar o policial militar de conhecimentos específicos indispensáveis à execução do serviço de segurança pública junto aos 300 postos policiais de cidadania e segurança, realizando um tipo de policiamento denominado policiamento comunitário (FEITOSA et all, 2006:14)

O curso seria destinado para Oficiais e Praças que trabalhariam nos 300 postos e estivessem classificados no Bom Comportamento ${ }^{23}$ durante 10 dias letivos, com uma

\footnotetext{
${ }^{23}$ De acordo com o Regulamento do Exército Brasileiro, adotado pela PMDF, todo militar tem suas condutas impróprias registradas na ficha de assentamento, assim como os elogios. O comandante da unidade, a partir das sindicâncias instauradas que resultaram em punições e dos elogios realizados, classifica o Comportamento das praças (soldados, cabos, sargento e subtenente) em excepcional, ótimo, bom, insuficiente e mau comportamento (Brasil, 2002)
} 
carga horária total de 80 horas/aula. O método de ensino seria a correlação da teoria com as possíveis práticas o que o policial poderia encontrar no cotidiano dos postos.

O corpo docente seria formado pelos próprios policiais da PMDF que estão nas unidades de ensino da instituição. Admitir-se-iam professores civis, todavia, desde que se dispusessem trabalhar gratuitamente.

Quadro 13 Currículo do Curso de Policiamento Comunitário

\begin{tabular}{|c|c|c|c|}
\hline Área de Ensino & $\begin{array}{l}\mathrm{N}^{\circ} \text { de } \\
\text { Ordem }\end{array}$ & MATÉRIAS CURRICULARES & \begin{tabular}{|l} 
CARGA \\
HORÁRIA
\end{tabular} \\
\hline \multirow{3}{*}{ Fundamental } & 01 & Relações Públicas e Humanas & 06 \\
\hline & 02 & Chefia e Liderança & 06 \\
\hline & \multicolumn{2}{|c|}{ Soma da Área do Ensino Fundamental } & 12 \\
\hline \multirow{5}{*}{ Profissional } & 03 & Noções de Direito & 20 \\
\hline & 04 & Noções de Policiamento Comunitário & 20 \\
\hline & 05 & Técnicas de Abordagens & 14 \\
\hline & 06 & $\begin{array}{l}\text { Normas Gerais de Ação do Posto Policial Cidadania } \\
\text { e Segurança }\end{array}$ & 06 \\
\hline & \multicolumn{2}{|c|}{ Soma da Área do Ensino Profissional } & 60 \\
\hline \multirow{4}{*}{$\begin{array}{l}\text { Atividades } \\
\text { complementares }\end{array}$} & 07 & Visitas e Palestras & 02 \\
\hline & 08 & A disposição da coordenação do curso & 02 \\
\hline & 09 & Formatura de Encerramento do Curso & 04 \\
\hline & \multicolumn{2}{|c|}{ Soma da Área das Atividades Complementares } & 08 \\
\hline \multicolumn{3}{|c|}{ SOMA DA CARGA LETIVA TOTAL } & 80 \\
\hline
\end{tabular}

FONTE: Feitosa et all, 2006

O tempo de cada aula seria de 50 (cinquenta) minutos, sendo reconhecida como hora/aula pela instituição. Não há na tabela os 40 (quarenta) minutos diários que são destinados às atividades militares como, por exemplo, hasteamento da bandeira nacional, atividades de marcha, entre outras.

Após a conclusão do curso, a equipe de planejamento projetou que o resultado seria ter policiais militares alinhados à filosofia de policiamento comunitário, "voltado para a defesa da comunidade do Distrito Federal contra a criminalidade que a cada dia a atormenta mais" (FEITOSA et all, 2006:01).

Por último, desenvolvido em outros três volumes, há a projeção da implantação dos PSCs. Para tanto, como mencionado anteriormente, houve a análise da densidade demográfica do DF por regiões administrativas, vinte nove à época. 
Quadro 14 Regiões Administrativas do Distrito Federal em 2007

\begin{tabular}{|l|l|}
\hline RA's & LOCALIDADE \\
\hline RA I & BRASÍLIA \\
\hline RA II & GAMA \\
\hline RA III & TAGUATINGA \\
\hline RA IV & BRAZLÂNDIA \\
\hline RA V & SOBRADINHO \\
\hline RA VI & PLANALTINA \\
\hline RA VII & PARANOÁ \\
\hline RA VIII & NÚCLEO BANDEIRANTE \\
\hline RA IX & CEILÂNDIA \\
\hline RA X & GUARÁ \\
\hline RA XI & CRUZEIRO \\
\hline RA XII & SAMAMBAIA \\
\hline RA XIII & SANTA MARIA \\
\hline RA XIV & SÃO SEBASTIÂO \\
\hline RA XV & RECANTO DAS EMAS \\
\hline RA XVI & LAGO SUL \\
\hline RA XVII & RIACHO FUNDO \\
\hline RA XVIII & LAGO NORTE \\
\hline RA XIX & CANDANGOLÂNDIA \\
\hline RA XX & ÁGUAS CLARAS \\
\hline RA XXI & RIACHO FUNDO II \\
\hline RA XXII & SUDOESTE E OCTOGONAL \\
\hline RA XXIII & VARJÃO \\
\hline RA XXIV & PARK WAY \\
\hline RA XXV & SCIA (SETOR COMPLEMENTAR DE IND E \\
& ABASTECIMENTO \\
\hline RA XXVI & SOBRADINHO II \\
\hline RA XXVII & JARDIM BOTÂNICO \\
\hline RA XXVIII & ITAPUÃ \\
\hline RA XXIX & SIA \\
\hline & \\
\hline
\end{tabular}

Após a análise da densidade demográfica, disposição geográfica das cidades (proximidades com outras regiões), entre outros fatores, a equipe entendeu que seria melhor agrupar algumas regiões administrativas no processo de implantação dos PSCs, 
Quadro 15 Regiões Administrativas aglutinadas para a implementação do Policiamento Comunitário

\begin{tabular}{|l|l|}
\hline PLANO PILOTO & $\begin{array}{l}\text { Brasília, Lago Sul, Lago Norte, Cruzeiro, SIA, } \\
\text { SCIA, Varjão, Jardim Botânico, Sudoeste e } \\
\text { Octogonal. }\end{array}$ \\
\hline GAMA & Gama \\
\hline TAGUATINGA & Taguatinga e Águas Claras \\
\hline BRAZLÂNDIA & Brazlândia \\
\hline SOBRADINHO & Sobradinho (I e II) \\
\hline PLANALTINA & Planaltina \\
\hline PARANOÁ & Paranoá e Itapuã \\
\hline NÚCLEO BANDEIRANTE & Núcleo Bandeirante \\
\hline CEILÂNDIA & Ceilândia \\
\hline GUARÁ & Guará, Park Way \\
\hline SAMAMBAIA & Samambaia \\
\hline SANTA MARIA & Santa Maria \\
\hline SÃO SEBASTIÃO & São Sebastião \\
\hline RECANTO DAS EMAS & Recanto das Emas \\
\hline RIACHO FUNDO & Riacho Fundo (I e II) \\
\hline CANDANGOLÂNDIA & Candangolândia \\
\hline
\end{tabular}

Fonte: Feitosa et all,

Todavia, pelo critério adotado pela equipe, ou seja, o de ser a quantidade de policiais por habitante, não havia a proporção necessária para atingir a meta da proposta de governo de implementar 300 postos em todo o Distrito Federal. A escolha de aglutinar Regiões Administrativas e alocar postos pela densidade demográfica criou uma necessidade de postos menores.

Quadro 16 Relação de postos por habitante nas áreas das Administrações Regionais aglutinadas

\begin{tabular}{|l|l|c|}
\hline REGIÃ̃ & HAB $^{\mathbf{2 4}}$ & $\begin{array}{c}\text { QUANT. MIN. } \\
\text { POSTOS }\end{array}$ \\
\hline PLANO PILOTO & 319.947 & 40 \\
\hline GAMA & 130.580 & 16 \\
\hline TAGUATINGA & 243.575 & 30 \\
\hline BRAZLÂNDIA & 52.698 & 07 \\
\hline SOBRADINHO & 128.789 & 16 \\
\hline PLANALTINA & 147.114 & 18 \\
\hline PARANOÁ & 54.902 & 07 \\
\hline NỨCLEO BANDEIRANTE & 36.472 & 05 \\
\hline CEILÂNDIA & 344.039 & 43 \\
\hline GUARÁ & 115.385 & 14 \\
\hline
\end{tabular}

${ }^{24}$ A equipe utilizou dados da pesquisa do IBGE de 2000, em que a população era de aproximadamente 2.051.000 de habitantes 


\begin{tabular}{|l|l|c|}
\hline SAMAMBAIA & 164.319 & 20 \\
\hline SANTA MARIA & 98.679 & 12 \\
\hline SÃO SEBASTIÃO & 64.322 & 08 \\
\hline RECANTO DAS EMAS & 93.287 & 12 \\
\hline RIACHO FUNDO & 41.404 & 05 \\
\hline CANDANGOLÂNDIA & 15.643 & 02 \\
\hline TOTAL & $\mathbf{2 . 0 5 1 . 1 4 6}$ & $\mathbf{2 5 5}$ \\
\hline
\end{tabular}

Fonte: Feitosa et all, 2006

Os outros 45 (quarenta e cinco) postos policiais, para atingir a meta de governo, a equipe planejou alocar nos espaços que teriam maior índice de violência ou fluxos de pessoas, ou até mesmo em possível crescimento desordenado que houvesse em alguma cidade.

A preocupação com as recomendações da ONU para a quantidade de policiais por habitante mediou a estimativa de ter 9.000 (nove mil) policiais destinados somente para o policiamento comunitário. Desta forma, teriam 01 (um) policial para cada 266 (duzentos e sessenta e seis) habitantes, proporção próxima da recomendada pela organização internacional que é de 01 (um) policial para cada 250 (duzentos e cinquenta) habitante.

O processo de implantação dos postos seria, primeiramente, na Região Administrativa da Asa Sul com a implantação de 08 (oito) PSC e, logo em seguida, em outras 03 (três) Regiões Administrativas.

A escolha da Asa Sul como projeto piloto de implantação deu-se porque a região tem, segundo os entrevistados, uma rede de proteção legal que envolve o GDF e a União. A legislação específica que assegura o tombamento da cidade como patrimônio cultural e guarda a concepção original urbanística de Lúcio Costa que contemplava Unidades de Vizinhança entre quadras residenciais contempla espaços destinados à prestação de serviço de forma harmônica e equidistantes.

Os espaços urbanos chamados unidades de vizinhança, segundo o projeto do Programa Comunitário de Referência Social, é mais um espaço da Asa Sul próprio para a implantação dos Postos de Segurança e Cidadania porque destina espaço para instituições religiosas, educacionais, culturais, desportivas e de lazer, além de biblioteca pública, postos de combustíveis, entre outros serviços que pretendem garantir qualidade de vida aos moradores próximos. 
A metodologia utilizada pela equipe foi em um primeiro momento analisar a região administrativa, processo que foi replicado para todas as outras cidades do Distrito Federal. Analisaram a renda per capita, a quantidade de automóveis, número de escolas, quantidade de hospitais, nível de escolaridade, naturalidade, tipo de residências (se em residência ou em apartamentos), quantidade de estabelecimento que oferecem serviços bancários, entre outras categorias que podem colaborar para os comandantes de postos planejarem ações.

A segunda parte do processo de análise foi acerca dos índices de criminalidade local registrados. Os analistas consideraram os seguintes tipos penais: homicídio, lesão corporal, latrocínio, roubos diversos, roubos com restrição da liberdade da vítima (seqüestro relâmpago), furtos diversos, tráfico e consumo de drogas, atentado violento ao pudor, estupro, porte e disparo de arma de fogo, perturbações da tranquilidade pública. A análise contemplava os horários, dias e locais com maior frequência por tipo de crime.

Em um terceiro momento de análise, a equipe elaborou o grau de risco ou grau de vulnerabilidade da população local. O escopo teórico que auxiliou a equipe foi a teoria da oportunidade de Lawrence Cohen e Marcus Felson (1979:64).

\footnotetext{
É irônico que os mesmos fatores que incrementam as oportunidades para desfrutarmos dos benefícios da vida podem igualmente incrementar a oportunidade para as violações predatórias [...] Ao invés de tomarmos os crimes predatórios simplesmente como indicadores de colapso social, podemos concebê-los como subprodutos da liberdade e da prosperidade tal como se manifestam nas atividades rotineiras de nosso cotidiano.
}

Esta é a citação que abre o capítulo do projeto que analisa os riscos de vulnerabilidade de cada comunidade. Para os analistas, segundo essa vertente teórica, a ocorrência do crime é motivada por um fator de oportunidade que a prosperidade incrementa nas relações sociais. Assim, nesse contexto, locais ou espaços urbanos mais desenvolvidos são preponderantemente favoráveis à ocorrência criminosa contra o patrimônio por apresentar alvos viáveis e compensadores.

Nesse diapasão teórico, seguido pelos projetistas, há a percepção de que a ação criminosa ou delituosa ocorre pela presença concomitante de três fatores: a presença da vítima, a ausência da vigilância e o agente motivado. É a teoria que vislumbra o crime pela figura geométrica do triângulo. Segundo esta teoria, basta focar as ações em um destes elementos constitutivos da ação criminosa para que esta não ocorra.

Assim, segundo os técnicos que planejaram o Programa, 
[...] tendo como referência a teoria da oportunidade, esse mesmo poder aquisitivo torna os habitantes da região vulneráveis a crimes de oportunidade, tais quais os roubos a transeuntes e com restrição da liberdade da vítima (sequiestro relâmpago).

Sendo composto o triângulo do crime por agente capaz, alvo disponível e falta de vigilância; mantido o perfil sóciográfico da região, uma das únicas variáveis capazes de diminuir a vulnerabilidade de sua população será o incremento da vigilância levada a efeito pelo policiamento ostensivo (Polícia Militar).

Por fim, vale ressaltar que o policiamento comunitário é a última palavra em filosofia e estratégia de policia preventiva no mundo. Baseada na parceria entre a Polícia Militar e a comunidade, a implantação do policiamento comunitário se revela uma ferramenta eficaz para romper o triângulo do crime.

Com a implantação do policiamento comunitário não só na Asa Sul, mas nas demais Regiões Administrativas do Distrito Federal, os delinqüentes terão diminuídas suas oportunidades de cometer crimes. Primeiro porque haverá o incremento da vigilância. Segundo porque uma comunidade bem orientada pelo seu governo, por meio da Polícia Militar, desenvolve em si uma cultura de segurança e evita se colocar em situações de risco. (FEITOSA et all 2006:33)

A estratégia de locação dos PSCs no espaço urbano segue esta lógica para tentar desmotivar o possível criminoso e para dar a sensação de espaço vigiado. Utilizando-se da prerrogativa de ser a Polícia Militar a instituição de policiamento ostensivo, havia a projeção de posicionar os postos de acordo com a possibilidade de maior visualização, aproximando a quantidade de efetivo pela quantidade da população local que tangencia a unidade policial para manter a quantidade próxima de policial militar por habitantes, e, por último, para manter a maior área possível de espaço vigiado. 
A lógica de locação no espaço da região administrativa da Asa Sul também seria utilizada para as demais regiões administrativas. Todavia, apresentamos apenas esta por se tratar de ser fácil demonstração pelo desenho urbanísticos das restas, própria da região central de Brasília. Após a instalação destes oito postos, estavam planejadas as instalações dos postos em outras três regiões administrativas, em Brazlândia, em Ceilândia e no Gama.

A região destacada em vermelho na figura abaixo representa o espaço da Asa Sul da região metropolitana de Brasília, objeto de análise.

Figura 3 Área de Análise objeto de instalação do Posto de Referência

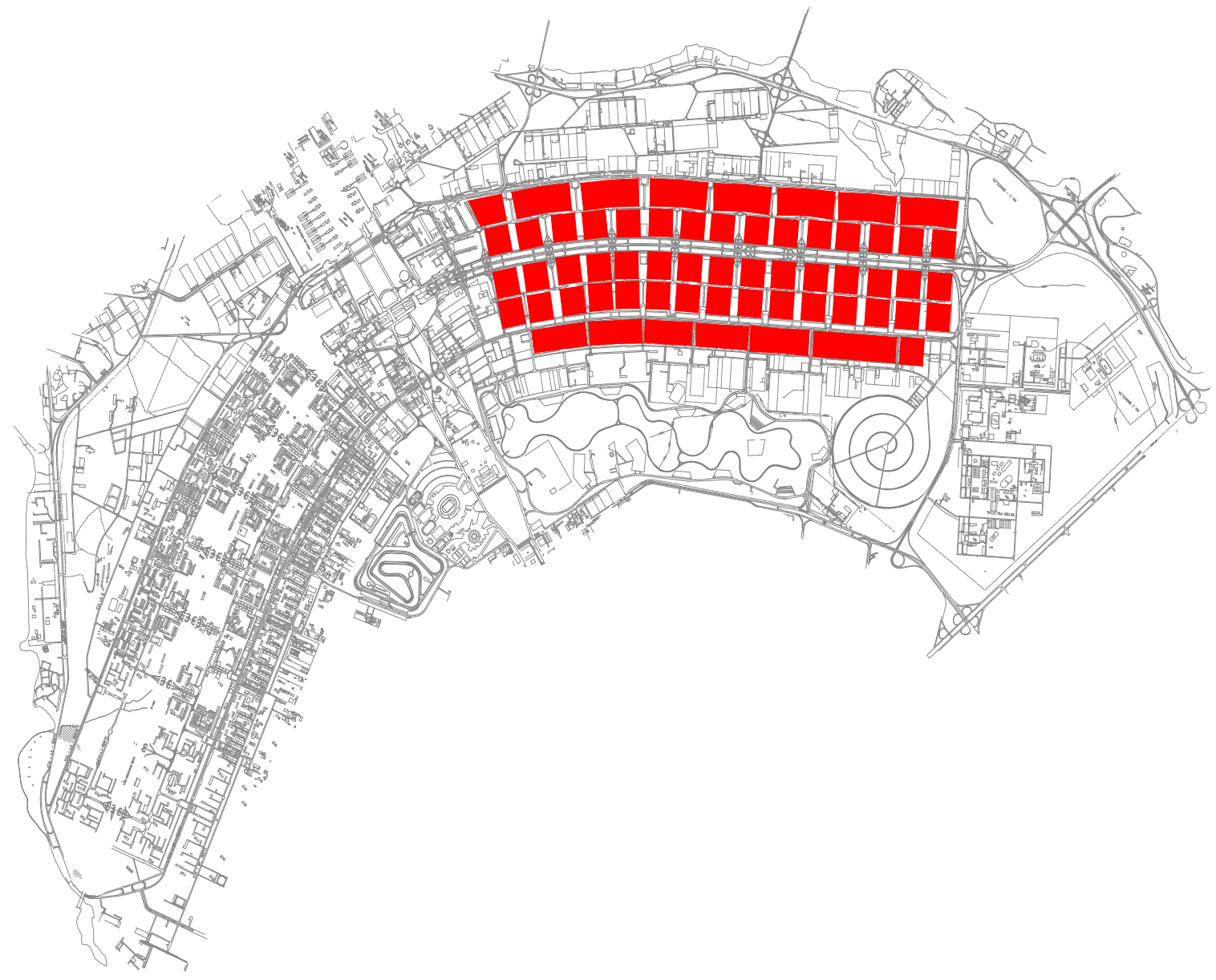

Fonte: Feitosa et all, 2006 
Como os espaços da Região da Asa Sul e Norte são semelhantes e como o processo de ocupação e organização do espaço no Distrito Federal é marcado pela tentativa em manter esta mesma lógica "racional” entre divisões Norte e Sul, atribuir numeração a ruas e conjuntos habitacionais e as quadras residenciais e comerciais terem tamanhos e características demográficas semelhantes, para os autores dos projetos a instalação piloto na região em vermelho demonstraria todas as assertivas e os possíveis erros no processo que poderia ser atribuídas às outras regiões.

Os postos seriam instalados nos espaços denominados de entrequadras. Como salientado, o desenho urbanístico de Brasília permite visualizar a equidistância de cada posto e a igualdade de responsabilidade atribuída pelos técnicos para cada unidade policial, conforme apresentado na figura abaixo

Figura 4 Locais projetados para instalação dos posto

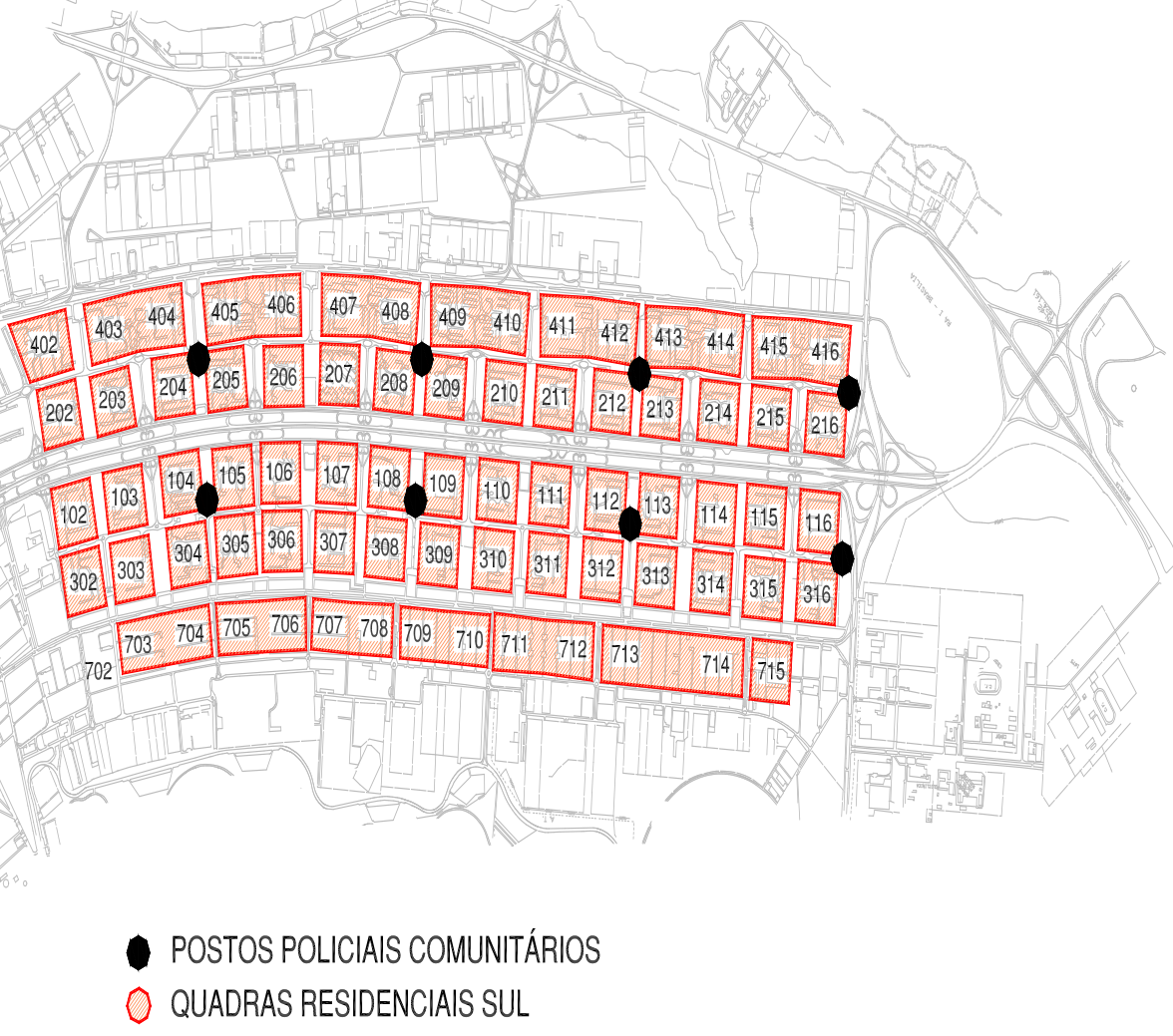

Fonte: Feitosa et all, 2006 
A área de responsabilidade de cada PSC, como mencionado, estaria relacionado com o espaço territorial e com a quantidade de habitantes locais. Assim, a responsabilidade de cada gestor de posto para organizar palestras, realizar campanhas informativas, convidar para reuniões, fiscalizar a realização das patrulhas próximas às escolas e aos comércios dentro da área de responsabilidade. Os policiais militares iriam patrulhar os mesmos espaços e orientar a mesma população preferencialmente.

Figura 5 Áreas de Atuação e responsabilidade dos Postos de Segurança e Cidadania

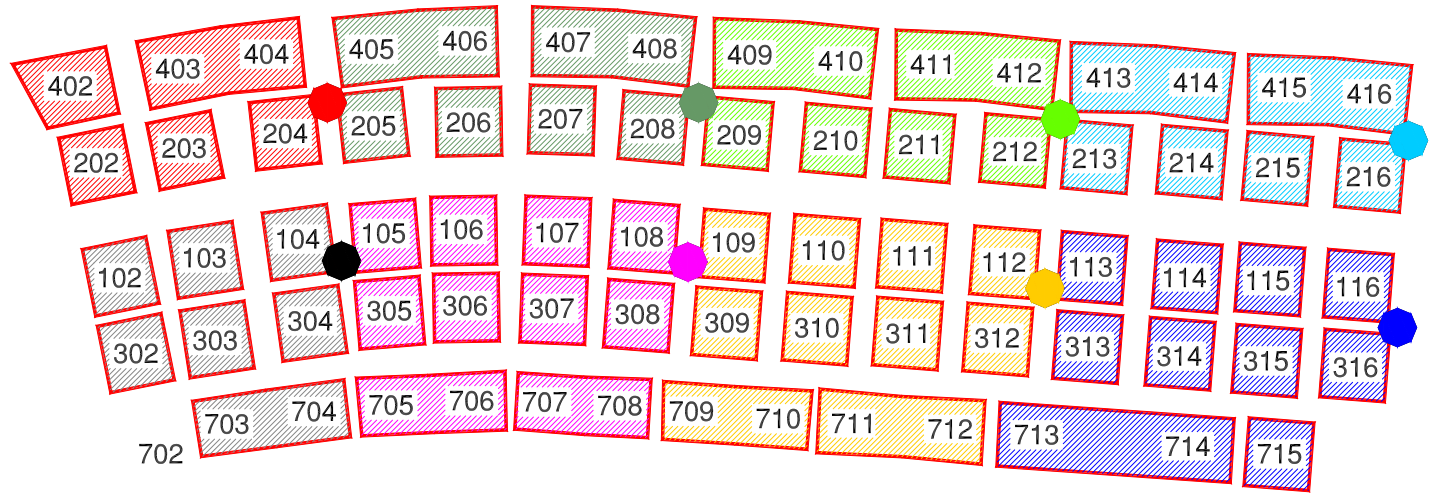

\section{DIVISÃO DAS ÁREAS DE RESPONSABILIDADE DOS POSTOS COMUNITÁRIOS}

A lógica de planejar pela disposição no espaço mediado pela Teoria do Triângulo do crime provocou dispor os PSC's mais próximos uns dos outros do que o necessário para provocar uma sobreposição de responsabilidade de patrulhamento.

Como demonstrado na figura anterior, cada equipe policial militar lotada em um posto seria responsável pelo policiamento ostensivo preventivo e repressivo em 06 (seis) 
quadras, todavia, não exclusivamente a estas regiões ao ser apresentada alguma demanda de urgência.

O raio de ação do posto para o patrulhamento é maior que a área de ação planejada de prevenção e de interação com a comunidade local, conforme a figura abaixo.

Figura 6 Área de Atuação dos Postos na Visão de Saturação

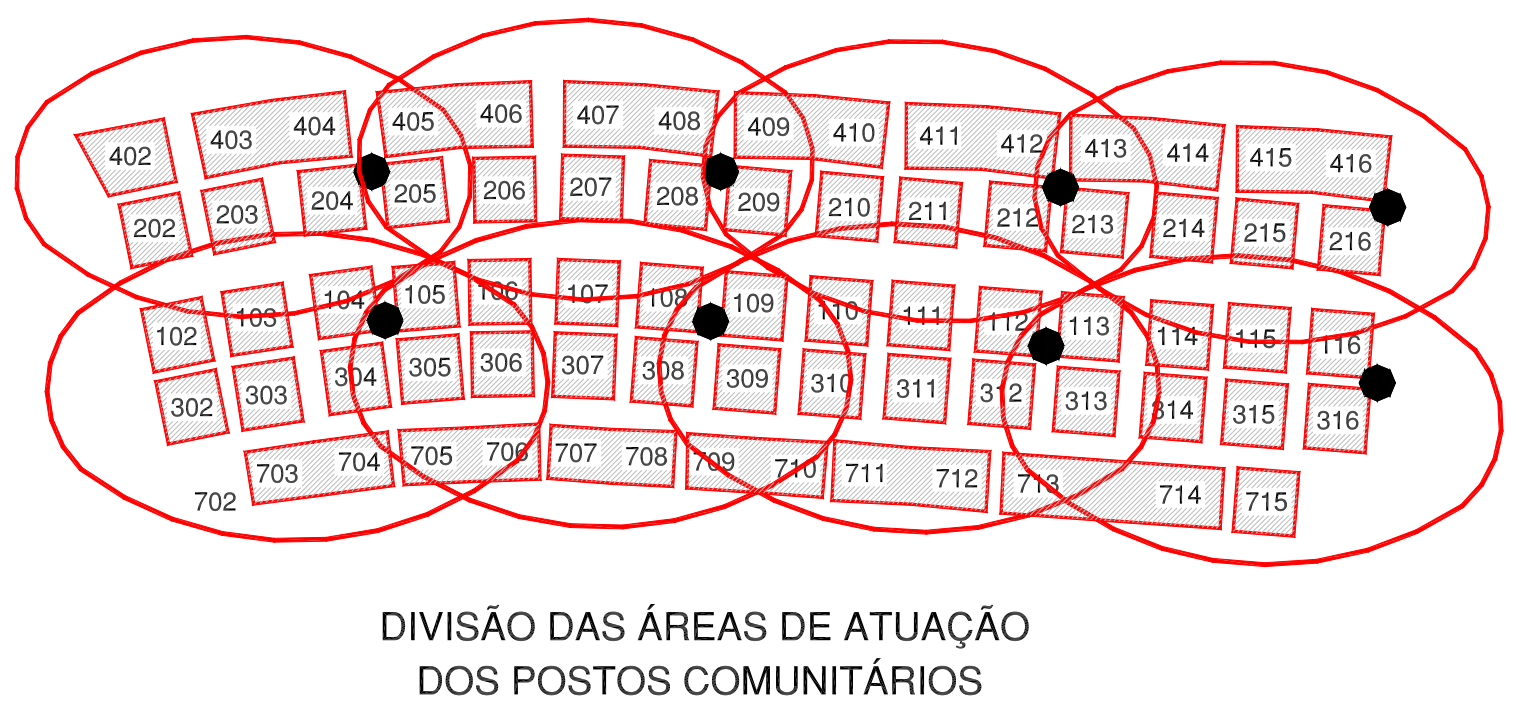

Esta sobreposição é chamada saturação da ostensividade em pontos predeterminados. Esses pontos são os comércios e as áreas de grande circulação de pessoas e veículos. Como a teoria do Triângulo do Crime tem como um dos vértices o estado de vigilância, a intensão dos planejadores foi aumentar a ostensividade para diminuir a probabilidade de crimes contra o patrimônios e os sequestros relâmpagos.

Assim, mesmo que a responsabilidade dos policiais esteja ligada à segurança de determinados moradores, ainda há o compartilhamento de responsabilidade para duas ou mais equipes policiais em determinados setores, principalmente nas áreas comerciais. 
Como demonstra a figura abaixo, os técnicos compreenderam que a ação conjunto de duas ou mais equipe provocaria o efeito da saturação da ostensividade policial para a diminuição do crime.

Figura 7 Áreas de Saturação de Policiamento de Segurança e Cidadania



As rondas policiais de cada posto seriam de acordo com a área de atuação da figura acima. Em cada região administrativa os postos também teriam uma proximidade de forma que a distância percorrida por cada viatura não passaria de 05 (cinco) quilômetros de perímetro, passando por áreas de saturação de policiamento.

Vale ressaltar que a proximidade entre os postos na Asa Sul, que seria também na Asa Norte de Brasília, estaria relacionada pela densidade demográfica provocada pela verticalização das habitações, todavia, em outras regiões administrativas, esta característica não é preponderante e a baixa densidade demográfica típica de cidades horizontais faria com que os PSC fossem mais afastados, mas o projeto contemplou um afastamento máximo de 05 (cinco) quilômetros de distância em torno da unidade policial, 
o que seria o caso de Ceilândia, região administrativa a quase 30 (trinta) quilômetros de distância de Brasília que, apesar da grande população, teria os postos policiais mais afastados uns dos outros.

Segundo os entrevistados, esta concepção de proximidade da unidade policial de cada posto com os moradores locais é fruto da discussão que a equipe técnica teve ao definir a concepção teoria de ser um policiamento de proximidade.

Além da vigilância motorizada realizada pelas equipes, o comandante do posto iria monitorar a área utilizando as câmeras de vigilância. Segundo o Oficial 2, haveria câmaras que transmitiriam sinais diretamente para a sala de comando dos postos. Assim, enquanto estivesse acontecendo o patrulhamento motorizado por automóveis ou motocicletas em determinadas áreas, a outra área seria monitorada diretamente do posto policial.

Além de contemplar serviços de segurança pública planejada, estava previsto pela equipe, segundo os entrevistados, um servidor público civil que trabalharia no posto para realizar os atendimentos que não estivessem diretamente relacionados à segurança pública, mas que poderiam influenciar na sensação de segurança.

Nas palavras dos entrevistados, os PCSs seriam um espaço para chamar a comunidade para dentro do Posto de Segurança com Cidadania porque ali o cidadão teria contemplado a maioria de suas demandas junto ao Estado. O que não fosse possível solucionar pelas ações policiais, o servidor do GDF iria anotar e o comandante do posto iria encaminhar a solicitação ao gestor competente, mesmo que de outra instituição. Assim, questões referentes à iluminação pública, mato alto, entre outras, seriam encaminhas oficialmente pelo gestor como uma questão de segurança pública.

Toda a implantação dos 300 (trezentos) postos policiais foi planejada para ser realizada entre 4 (quatro) e 08 (oito) anos, deixando de ser uma política de segurança pública de governo e transformando-se em uma política de Estado. Assim, algumas medidas seriam realizadas a médio prazo como, por exemplo, a formação policial dos quase 4.000 (quatro mil) policiais que seriam contratados para reforçar o policiamento, e a implementação total a longo prazo, com um total de oito mil policiais no policiamento comunitário.

O projeto elaborado para a implementação do Programa Comunitário de Referência Social para serem executados em Postos de Segurança e Cidadania foi uma 
fórmula com viés técnico encontrada à uma decisão política de alguém de fora da área de segurança que tinha poder de decisão.

Essa prática demonstra como as influências fora do campo da segurança pública influenciaram os processos de formação das políticas e das ações cotidianas policiais. Mais do que isso, indica como outros atores não pertencentes ao campo de controle do delito, às instituições policiais ou às várias agências que pesquisam as relações da criminalidade, do controle do conflito e da violência influenciam as ações governamentais, a governança e as estruturas policiais.

A roupagem técnica dada à decisão política incrementou a Doutrina do Policiamento Comunitário como conteúdo nos postos policiais prometidos. Como se pôde perceber, a política de segurança pública proposta pela equipe de transição estava pautada em três pilares interpretados das teorias referentes ao Policiamento Comunitário: a aproximação dos Policiais Militares com a comunidade policiada; a mudança de procedimentos dos policiais militares ao compartilharem com os cidadãos os processos de escolhas dos problemas, apresentação de possíveis soluções com metas estabelecidas e avaliações das ações; os postos policiais como pontos de referência da Polícia Militar, representante do Estado; e como base para o desenvolvimento das ações de Policiamento comunitário, como reuniões com representantes da sociedade civil, planejamento, entre outros. As próximas seções deste trabalho apresentam como foi preparada a implementação do Policiamento Comunitário pelo Governo Arruda e como se a política se mantém. 


\section{CAPÍTULO 03 - POLÍTICAS DE SEGURANÇA PÚBLICA: COMO AS POLÍTICAS MUDAM}

O processo da construção das bases para implementar a política vencedora das eleições inicia-se em 2007 até o final do ano de 2008, do início do Governo da legenda vencedora até a derrocada do Governador Arruda. O governo inicia com a composição dos quadros e a nomeação do Comandante da Polícia Militar e do Secretário de Segurança foram variáveis fundamentais para o processo de construção e para a fase de préimplementação do Policiamento Comunitário no Distrito Federal.

O Secretário de Segurança escolhido foi o General do Exército Brasileiro Cândido Vargas de Freire que ficou no posto até junho de 2008. Para a Subsecretaria de Programas Comunitários, responsável legalmente para conduzir a política de segurança pública no Distrito Federal foi o Soldado da PMDF Normando. Esta escolha causou alguns atritos entre oficiais da Polícia Militar e o Sub Secretário, já que pelos regulamentos da PMDF, o soldado era um subordinado, mas politicamente tornou-se um superior hierárquico. Esta relação tornou-se conflituosa e o acesso do Subsecretário de estado a determinados grupos dentro da PMDF foi dificultado, assim como o desenvolvimento de suas recomendações.

Estes conflitos perduraram também dentro da PMDF e reverberavam na SSP/DF. Realizar cursos pela SENASP/MJ, presencial ou a distância, ganhou nuances por questões políticas que demonstravam diferenças de paradigmas de policiamento. Não só pela resistência dos policiais militares de rua, mas pela resistência do próprio Secretário de Segurança. Segundo o Subsecretário de Programas Comunitário, responsável pela condução das política de segurança do Policiamento Comunitário, havia um conflito interno entre os executivos da Secretaria de segurança e outro conflito externo entre a Suproc e alguns oficiais da PMDF.

Ambos os conflitos sobre o mesmo objeto, a implementação da nova política. As causas também: alguns oficiais da PMDF e o Secretário de Segurança compactuavam com a política de repressão policial ao crime e com o ethos guerreiro do policial militar e percebiam no Policiamento Comunitário uma ameaça à segurança pública por não ser um política de produção de resultados, ou, nas palavras ouvidas pelo subsecretário da SUPROC; "uma perda de tempo".

Portanto, haviam forças conflituosas da SSP/DF com poder decisório da SSP/DF, representando, entre outros, a comunicação direta com o Governador do Distrito Federal, 
e outra, força conflituosa colaborativa na PMDF, que era a comunicação com os policiais de rua. Segundo o Soldado Normando, SubSecretário de Estado da Subsecretaria de Programas Comunitários, alguns oficiais da PMDF se sentiram desprestigiados e outros grupos não aceitavam a mudança do tipo de policiamento.

Eles achavam que a gente estava querendo intervir na administração da Corporação então não aceitavam de jeito nenhum. Visão pequena mesmo, visão mesquinha, mais era mais ou menos isso mesmo - apesar de que a gente no período que esteve lá ter conseguido muita dotação orçamentária pra poder implementar tudo isso. A PM via com muita insatisfação o fato da Secretaria de Segurança chamar esse tipo de discussão, tanto que a gente teve um determinado momento histórico, mas não vamos falar de nomes, que a gente precisou ir até ao governador para que a PM mandasse os policiais fazerem o curso, eles não queriam nem mandar os policiais fazer o curso de Polícia Comunitária porque achavam que era desnecessário. (Soldado Normando, SubSecretário da Suproc)

Esses conflitos perduraram e dificultaram o início da implementação, necessitando a intervenção do Governador Arruda com a troca do Secretário de Segurança para diminuir as barreiras políticas que estavam estabelecidas. Segundo o Soldado Normando, a política só começou realmente a ser implementada após a intervenção e com a nomeação do Delegado da Polícia Federal Valmir Lemos que foi mais receptivo.

Desta forma, neste período, os fluxos (indicadores demonstrando a alta criminalidade violenta, capital político de apoio e solução "moderna" para problemas antigos) continuavam alinhados e a janela de oportunidade de formação da agenda agora torna-se uma janela de oportunidade de implementação. Nesse sentido, compreendemos que enquanto houvesse o fluxo alinhado, mantinham-se as condições para as fases que denominamos de pré-implementação, implementação e manutenção da política de segurança.

Outros atores começaram atuar no cenário do governo após a eleição. Grupos de interesse (industriais, grupos internos e externos) começaram a agir e a interferir na fase 
de pré-implementação. Segundo o Subsecretário da Suproc, um empresário da cidade do Guará foi nomeado Coordenador de uma Gerência apenas para coordenar a compra dos postos comunitários.

[...] era uma gerência independente chamada "Gerência dos Postos Comunitários de Segurança" o primeiro gerente foi o Giroto e depois do Giroto foi o Coronel... no começo do governo Arruda, [...] era o Serra e esse coronel era o subcomandante dele... Pena! Coronel Pena, depois que o Giotto saiu o Coronel Pena assumiu. Então a parte da construção do posto, onde ia ser construído e a interlocução com a empresa que construía era dessa gerência, onde ia ser construído, e a Secretaria de Segurança só entrava com a filosofia, ou seja, eram apenas os cursos, né, e em algum momento lá a Secretaria fez a interlocução com o governo federal a parte da liberação da estrutura física dos postos porque em muitos postos estava faltando ar condicionado, estava faltando cadeira, faltando computador, então a Secretaria entrou para ajudar a colocar os equipamentos, né? Mas a construção era da gerência e a parte operacional era da PM, a Secretaria de Segurança ela apenas oferecia os cursos de Polícia Comunitária para o pessoal que ia trabalhar nos postos. (Soldado Normando, ex-subsecretario da Suproc)

Essa gerência só teve a competência de comprar as instalações dos postos. Os equipamentos para trabalho, as viaturas, treinamento dos policiais, reuniões dos conselhos comunitários ficavam a parte da Suproc. Essa divisão de tarefas na Secretaria de Segurança com a nomeação do empresário para uma Gerencia afastou a equipe que produziu o projeto inicial apresentado na campanha eleitoral e mudou as concepções originais. A única parte da ideia inicial mais visível foi a quantidade de 300 (trezentos) postos para serem instalados no Distrito Federal. $\mathrm{O}$ fomento à integração entre as agências de segurança pública também foi descartado e a Polícia Militar foi a única agência foco das ações para a implementação do Policiamento Comunitário no Governo Arruda. A 
proposta inicial foi desfigurada no processo de implementação. Após a compra dos postos esta Gerência foi desconstituída.

Todavia, as redes constituídas foram mantidas e novas conexões foram realizadas. A experiência inovadora de um oficial da PMDF agindo de forma individual tentando implementar o policiamento comunitário na cidade do Guará o destacou na comunidade local. Esta rede estabelecida entre o oficial e a comunidade gerou fatos inesperados: a indicação do então major para trabalhar na Senasp. Segundo o policial, um líder comunitário conhecia várias pessoas no Ministério da Justiça e fez o convite

Isso porque ele esteve lá e conhecia as pessoas e disse "Pelo trabalho que você está desenvolvendo aqui, eu posso indicar o seu nome e falar com as pessoas que tem poder pra isso?" eu falei "Eu não sei nem o que faz a SENASP”, eu não conhecia a SENASP direito, mas ele falou "Cara você leva jeito pra coisa e você também não tem muita vida porque você passa o dia inteiro, manhã, tarde, noite à disposição da unidade; a noite é reunião com a comunidade, é tarde, é final de semana, você quase que não tem vida com sua família, mas você é dedicação exclusiva", e como ele me via nessas reuniões e ele participou das ações da unidade... [...] Então ele foi a primeira pessoa que me indicou, ele conhecia o Comandante Geral, tinha acesso a ele, e disse "Olha eu tenho um nome pra indicar", e o Comandante Geral indicou três nomes para a SENASP aqui do DF, era um major; eu, tenente-coronel e indicou um coronel - aí alguém da SENASP, não sei porque, me escolheu (Oficial 4, ex-coordenador de Polícia Comunitária na SENASP/MJ)

Esses contatos realizados e a lotação do Coronel da PMDF na SENASP na fase inicial teve um papel fundamental na comunicação entre o Governo Federal e o Governo do Distrito Federal. Cabe destacar que o planejamento inicial contemplava apenas mudanças de ações dos agentes de segurança pública. À sociedade civil foi dado um papel passivo que contemplaria as ações policiais militares e seriam conduzidas a figurarem com a participação guiada. Todavia, foi a ação de um cidadão da comunidade que 
possibilitou colocar a "pessoa certa" (policial militar comprometido com o policiamento comunitário) "na hora certa" (início da implementação da política no Distrito Federal). É com este cenário que inicia-se a política de segurança pública que marca o governo Arruda sustentada em três pilares: os 300 postos comunitários, a mudança das práticas policiais e maior envolvimento da sociedade.

\subsection{Os Postos Comunitários de Segurança}

Cabe ressaltar que já fazia parte da cultura policial militar no Distrito Federal ter postos policiais, assim, a política de implementar postos já era uma solução conhecida e estabelecida na região. Todavia, cada unidade policial fazia o próprio planejamento para instalar e operar os postos. Assim, o financiamento para a implantação, o tamanho dos postos, o material de composição das paredes, o mobiliário, a localização, o tamanho do efetivo policial militar, entre outras características, era definida pelo comandante da unidade policial.

Na maioria das regiões administrativas do Distrito Federal havia postos policiais nos terminais rodoviários, próximos a alguns aglomerados de residências, em ruas entre comércio, em hospitais e em rodovias que serviam como local de referência de prestação de serviço para a comunidade, assim como, em alguns casos, como posto base de controle territorial.

Assim, havia postos nas áreas urbanas e nas áreas rurais. Postos que só funcionavam no período diurno e postos que ficavam abertos $24 \mathrm{~h}$. Havia postos que funcionavam com 04 (quatro) equipes, em regime de plantão de $24 \mathrm{~h}$ para cada equipe e havia postos com 05 (cinco) equipes em turno de 12h, sendo 02 (duas) equipes revezando no período diurno e 03 (três) equipes no período noturno. Cada equipe era composta por, no mínimo 02 (dois) policiais militares.

Havia duas vias de financiamento para a construção e implantação dos postos policiais: a financiada pelo Estado, com verba da PMDF, planejada estrategicamente para controle territorial ou para diminuir índice locais de criminalidade; e por mobilização da sociedade civil organizada ou por forças políticas (sendo partidárias ou não).

Para esta segunda via de financiamento, que era recorrente, a instalação de postos policiais até então era um jogo político entre o Comandante da unidade local e a sociedade 
civil organizada. Líderes de associações, comerciantes, entre outros, negociavam a localização e como seria a implantação.

No decorrer da minha carreira policial militar já tinha trabalhado em vários postos e testemunhado alguns episódios do nascimento da concepção da instalação dos postos até uma possível integração entre agências de segurança. Em áreas rurais, trabalhei em postos grandes, semelhantes a casas, com espaços para dormir e banheiros que possibilitavam banho, havia também cozinha. Os plantões eram em turnos de 24 (vinte e quatro) horas por serem distantes e trocar as equipes duas vezes por dia poderia desgastar muito o grupo.

Os trabalhos desenvolvidos por policiais que trabalhavam nos postos rurais eram os trabalhos que mais se aproximavam da concepção de policiamento comunitário. Neste postos, há uma integração maior entre comunidade local e policiais militares. Como os policiais militares com maior tempo de serviço têm um capital social ${ }^{25}$ maior e predileção ao escolher tipos de serviço, escalas de serviço, equipe para trabalhar, geralmente eram os mesmos policiais que trabalhavam nos postos. Somente tive a oportunidade de trabalhar nestes postos porque havia o momento em que os policiais mais antigos gozavam férias. A comunidade local conhece os policiais pelo nome e sabe até mesmo a escala de serviço. Os policiais mediavam diversos tipos de conflito, informalmente, e retornavam para verificar se a situação estava realmente resolvida.

Havia sugestões informais dos moradores aos policiais para melhorar o policiamento e os moradores seguiam recomendações de segurança, feitas pelos policiais. Havia maior poder de decisão por parte dos policiais em relação a cadeia de comando. Geralmente, por ser uma localidade afastada, o controle institucional é menor, em alguns lugares não funciona rádio, celular, então a decisão é da guarnição de serviço com a comunidade.

Em Taguatinga, onde já havia postos entre algumas quadras residenciais, em hospitais, no centro da praça e próximo a comércio, foi solicitado ao comandante do batalhão que instalasse um posto policial próximo a uma escola, que ao mesmo tempo tangenciava uma rua comercial e ficaria próximo à área residencial. A solicitação foi atendida e o posto foi construído com o apoio financeiro da comunidade local.

\footnotetext{
${ }^{25}$ Existe um jargão militar que Antiguidade é posto. Geralmente esta frase é utilizada demonstrar que o policial militar com maior tempo de serviço tem alguns privilégios na instituição quando comparados aos policiais novinhos/recrutas ou entre até mesmo os pares.
} 
Comerciantes e moradores construíram um posto de aproximadamente $20 \mathrm{~m} 2$, onde cabiam uma mesa de escritório, um sofá e um sanitário. O efetivo destinado era de 02 (dois) policiais militares por turno de 12 (doze) horas.

Trabalhei neste posto por alguns plantões. Não foi constante porque a escalação era por setor, e quando faltava policial de algum setor havia o remanejamento de policiais por prioridade para manter outros policiais em viaturas para realizar o policiamento ostensivo nas principais áreas e para que houvesse um maior êxito no atendimento das ocorrências que eram informadas via rádio pela Central de atendimento ou por cidadãos. Assim, nem sempre havia viatura policial no posto, como também nem sempre havia nos outros postos. Nesse sentido, alguns dos postos eram instalados para dar segurança a uma pequena comunidade próxima.

Certa vez a mesma representante da associação de moradores da quadra solicitou que houvesse um Bombeiro Militar também no posto policial. Nós, policiais militares de plantão, não sabíamos da solicitação. Chegou um capitão da instituição co-irmã. Realizamos os ritos militares de apresentação com os devidos sinais de respeito. $\mathrm{O}$ Capitão do Corpo de Bombeiro entrou na pequena sala, olhou em silêncio por um minuto, observou o banheiro, e então avisa à representante de moradores que ali não havia a possibilidade de ter um bombeiro militar trabalhando 24 (vinte e quatro) horas porque não havia um ambiente para ele descansar (em beliche ou camas, por exemplo), não tinha uma geladeira e outros mobiliares para que o militar pudesse fazer uma alimentação com dignidade durante o plantão.

A possível integração das instituições militares responsável pela segurança daquela área, articulada politicamente pelos representantes da associação de moradores local, terminou ainda no processo de implantação. E assim era o processo de instalação de postos no Distrito Federal, as relações sociais nos micros-espaços sociais davam formas peculiares a política de segurança local moldadas pelas forças políticaseconômicas locais e pelos valores dos policiais militares. Nos espaços em que há um desequilíbrio nítido destas correlações de força há o sufocamento de um pelo outro.

Todavia, agora estava em curso a implantação de uma política que pretendia padronizar os espaços, as relações, a quantidade de pessoas, os materiais necessários para o trabalho, entre outras. Para tanto, houve a celebração do convênio 633053/2008 entre o Governo do Distrito Federal com a SENASP/MJ no valor de quase R \$ 5.400.000,00 (cinco milhões e quatrocentos mil reais) para que o Governo Federal financiasse a compra 
de automóveis, mobiliário, móveis, equipamentos, entre outros materiais que o Governo local entendeu necessário para a implantação e execução da nova política de segurança pública.

O início da implantação do policiamento comunitário no Distrito Federal pelo Governo Arruda está associado ao início da instalação dos Postos Comunitários de Segurança. Todavia, ressalto que havia outras ações como, por exemplo, as ações vinculadas à área de ensino com cursos para os policiais militares. Entretanto, para a população, assim como para mim, enquanto policial militar, e para os outros policiais que estavam na atividade fim, para os policiais de rua, a modificação das ações cotidianas só acontecem ao vislumbrar o posto policial em determinada área. Não tínhamos a percepção de que a SENASP/MJ estava financiando a compra de materiais ou cursos para a SSP/DF. Não sabíamos o quanto estavam interligadas as duas Secretarias, nacional e distrital.

Já a SSP/DF, juntamente com o Comando Geral da PMDF estavam realinhando o planejamento da implementação da política pública com as novas configurações política e econômica. A convicção política de instalar os 300 postos continuava. E de ser este o marco simbólico de toda a política também. Assim, os postos que foram implantados foram uma adaptação, ou releitura, do projeto inicial dos Postos de Segurança Cidadã.

Para esta reinterpretação se concretizasse nos moldes da proposta de implantação do agora eleito Governador José Roberto Arruda, foi contratada uma empresa de arquitetura e urbanismo para desenvolver o projeto dos postos seguindo algumas matizes da Secretaria de Segurança para a implantação dos postos e início da implantação da política pública.

Segundo os arquitetos que participaram da concepção do projeto, o Plano de Segurança do Distrito Federal, que contemplava a implantação dos Postos Comunitários de Segurança, havia a preocupação de que os PCS's fossem mobiliários, isto é, não fossem fixos no espaço urbano. Assim, a partir da pré-produção industrial destas unidades, o projeto construído pelos arquitetos apresentava três módulos (módulo da torre, módulo básico e módulo de ligação), que comporiam duas tipologias: os Postos comunitários de Segurança Simples e os Postos Comunitários de Segurança Compostos. Conforme as figuras abaixo, podiam ser retirados do espaço e afixados em outra plataforma de concreto previamente construída com os recursos hídricos e elétricos. Esta mobilidade é possível porque foi projetada para que os módulos possam ser içados em caminhão convencional. 
A figura abaixo representa a planta baixa do módulo do PCS simples em que há a representação da sala de atendimento ao público, de um sanitário para uso dos policiais militares e de uma copa. Há também o módulo da torre de observação que fica próxima à unidade. A área total construída deste módulo é de, aproximadamente, 28,00m2, excluindo a torre.

Figura 8 Posto Comunitário de Segurança. Módulo Simples
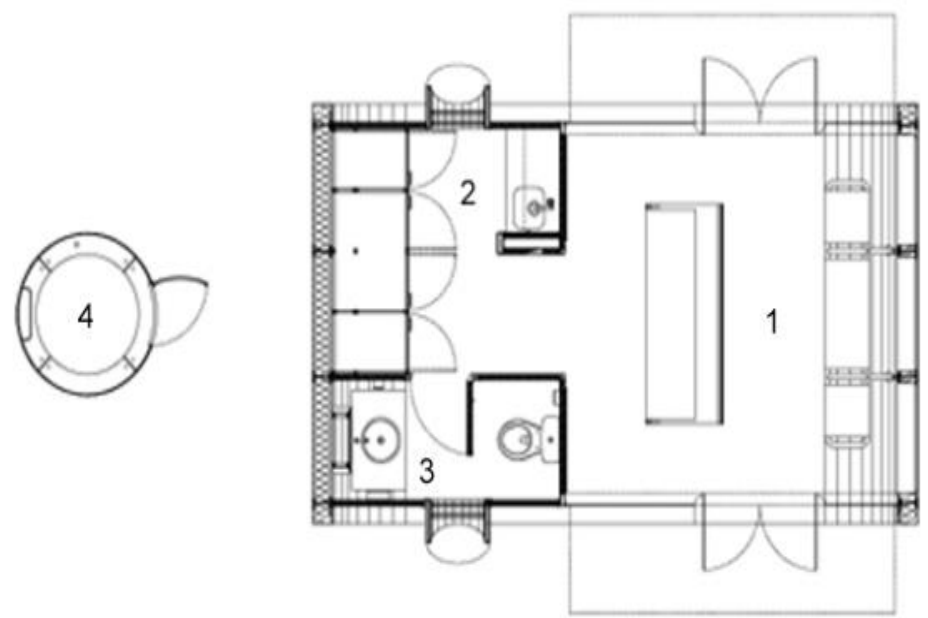

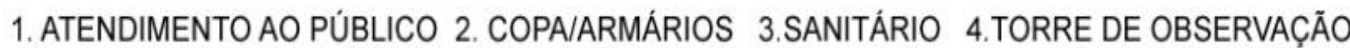

Já no módulo de PCS composto, há mais uma sala de atendimento ao público com dimensões semelhantes ao PCS simples. Também já há a possibilidade de o policial utilizar ambientes com dois sanitários disponíveis e teria a sua disposição ambiente com chuveiro. A área total $57,00 \mathrm{~m} 2$ e interligada por um ponte de concreto. 

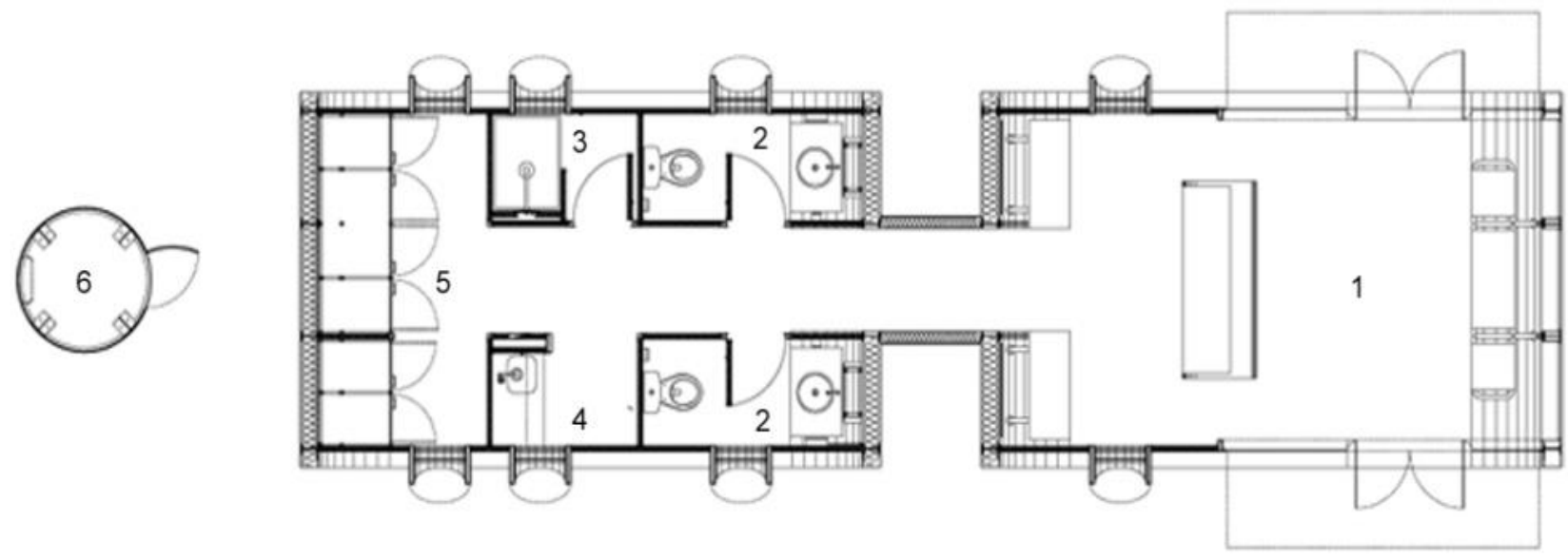

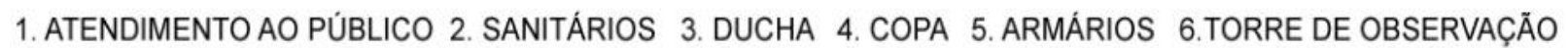

A estrutura de ambos os módulos é composta do mesmo material. São estruturas de aço, com o revestimento externo de fibra de vidro com isolamento termo-acústico ocupando o miolo, e revestimento interno em chapa de aço. O piso e de chapa de alumínio. As portas e as paredes laterais são de vidro transparente.

Nas duas concepções de posto, seja ela simples ou composta, somente é possível $\mathrm{o}$ atendimento por dois policiais em um móvel tipo balcão que possibilitava o atendimento do cidadão em pé na única sala do modulo, utilizada como sala de atendimento ao público.

Além das dimensões serem diferentes do projeto inicial, também há diferenças na concepção de como os policiais trabalhariam nos postos. Os recursos para a permanência são mais limitados. Dormitórios, copa com geladeira, fogão não estão mais previstos. Somente alguns postos teriam a sala de reunião com a comunidade, nos módulos de PCS compostos. Também não teriam banheiros privativos para os policiais, nem banheiros para pessoas com necessidades especiais.

Também não há mais a possibilidade de ter um servidor do Governo para passar as demandas da comunidades às agencias responsáveis. $\mathrm{O}$ posto deixa de ser um local de referência de cidadania pensada originalmente pela equipe da campanha eleitoral e passa ser uma referência de segurança pública pela nova concepção. 
Já a determinação de alinhar as práticas policiais à nova concepção de policiamento comunitário foi realizada por portarias e diretrizes do Comando Geral da PMDF aos Comandantes de unidades policiais militares, o que será apresentado com maior substancialidade na próxima seção. Todavia, já e possível mencionar a intenção do Comando Geral ao transmitir aos seus comandados as orientações para a implantação dos 300 (trezentos) postos policiais.

A densidade demográfica de 8.000 (oito mil) pessoas por área ou uma concentração máxima de 2.000 (duas mil) residências, o grau de periculosidade, a quantidade de fluxo de veículos ou de pessoas, os índices de criminalidade, entre outras, foram algumas das variáveis que orientaram as escolhas dos pontos de instalação pela Polícia Militar do Distrito Federal para iniciar a implantação da política pública do novo Governo do Distrito Federal.

Além dessas variáveis, foram considerados alguns dos pontos previamente analisados pela equipe que trabalhou na eleição. Além destes pontos, foram solicitados sugestões dos comandantes das unidades policiais de cada região administrativa. Alguns sugeriram os mesmos locais que já existiam postos policiais. Esta escolha se deu porque neste caso não seria necessário desativar postos em detrimento da nova política de segurança.

No início de 2007, o então comandante de uma unidade policial militar encaminhou mensagem resposta para seu comandante imediato sugerindo os locais de instalação dos postos policiais. Na mensagem, o comandante local apresenta um estudo com os locais indicados (que já tinham postos policias anteriormente) e apresentava as justificativas, entre elas quem era o responsável pelo pagamento das despesas de água e luz. Em um determinado posto policial a Associação de Moradores era o responsável, já em outro posto era a Administração Regional da cidade.

Na mesma mensagem o oficial demonstra que não tinha conhecimento do projeto inicial da campanha eleitoral e nem do projeto de posto que estava para ser instalado. $\mathrm{O}$ oficial sugere na mensagem que fossem utilizados os postos que já estavam em atividades, fazendo apenas algumas reformas. Para os locais que ainda não havia posto policial, um modelo de posto policial enviado foi anexado com um projeto que contemplava um lote de 1000 (mil) metros quadrados com a edificação do posto no centro do lote com um total de 300 (trezentos) metros quadrados de área construída. O cuidado com a segurança dos policiais também foi observado, ao sugerir que fossem cercados com alambrados, com 
boa iluminação externa e com apenas uma entrada para facilitar a observação dos policiais em serviço.

A instalação dos postos, como marco político de início da política de segurança pública pelo Governo Arruda, iniciou em Brazlândia com a instalação do primeiro Posto Comunitário de Segurança com a nomenclatura de PCS 001. É o início do cumprimento da promessa de campanha da instalação dos trezentos postos comunitários feita na campanha política.

Fotografia 1 Posto Comunitário de Segurança em 2008

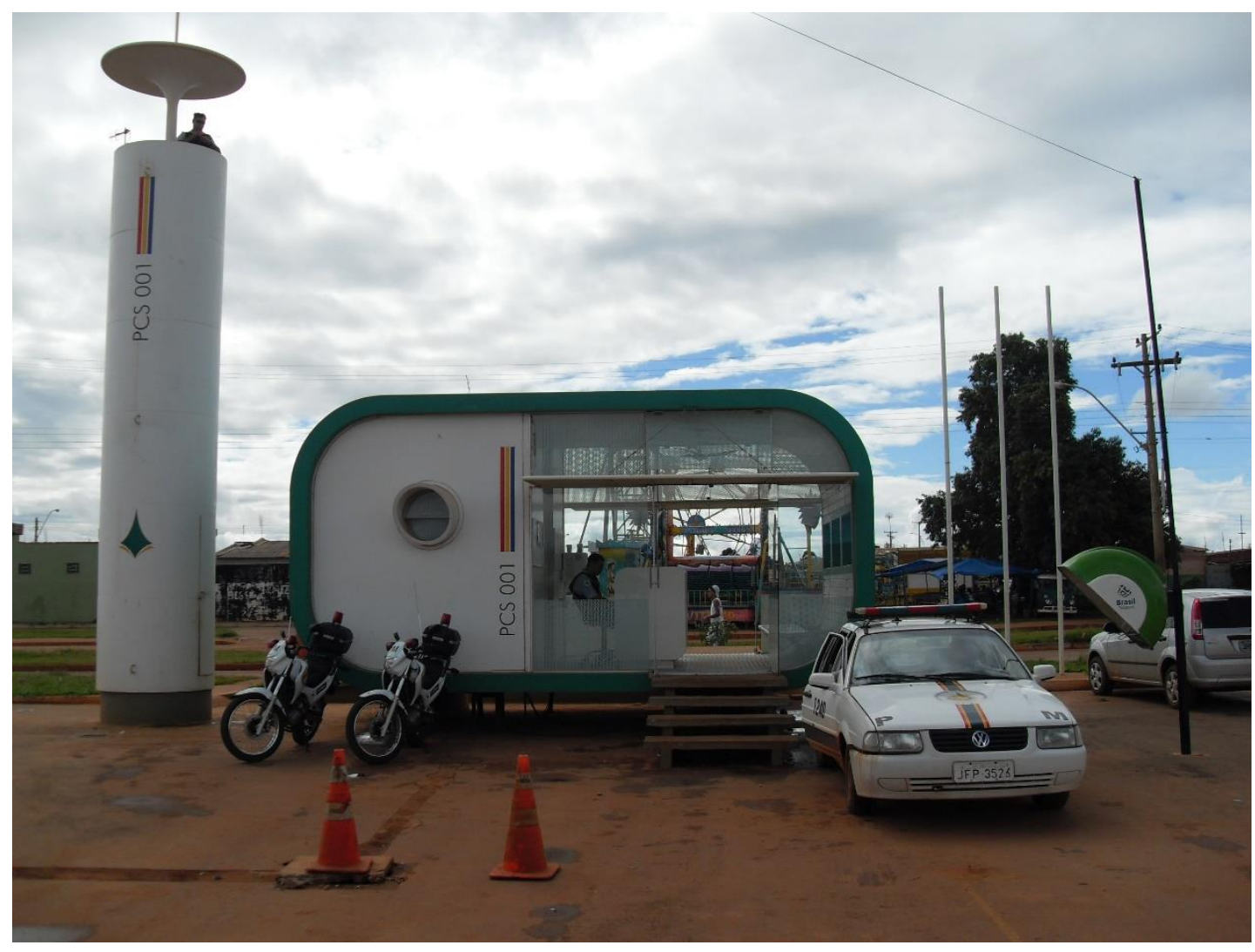

Fotografia dos arquivos do autor, registrada em 2008

O local foi o mesmo que estava no planejamento da campanha eleitoral. Um espaço que ainda não tinha posto construído, perto de uma feira livre, entre uma quadra residencial e uma rua comercial de um assentamento residencial recente. Do recém- 
instalado PCS era possível visualizar o comércio das 03 (três) quadras residenciais e das ruas comerciais. Foi disponibilizada uma linha telefônica com o número 3910-1001. A lógica foi padronizar o prefixo telefônico e os números restantes serem o número do PCS. Assim, para o PCS 103, o número telefônico seria 3910-1103. Este número do PCS era grafado no módulo Torre e no módulo do posto, conforme a fotografia, a intenção era facilitar a ligação telefônica do cidadão para qualquer posto policial, mesmo não estando em uma cidade ou quadra que reside ou que conheça.

A primeira Diretriz do Estado Maior da PMDF no ano de 2008 foi uma determinação aos comandantes de unidades policiais militares para padronizarem a implantação da nova política de segurança pública. A determinação continha ordens de como seriam as atividades de policiamento comunitário nos postos e quais os recursos. Da mesma forma que o projeto da campanha eleitoral, demonstrava quantos policiais estariam, a escala de serviço, a quantidade de veículos, entre outras. Esta determinação era para a instalação dos 300 (trezentos) postos.

Foi determinado que houvesse a quantidade mínima do efetivo total de 16 (dezesseis) policiais no posto para desenvolver todas as atividades. Sendo que 01 (um) sargento e 01 (um) cabo que desenvolveriam atividades de comandante do PCS. Também determinava que para realizar as rondas, atender ocorrências e fazer as visitas comunitárias o comandante do posto deverá deixar sempre um policial para a segurança local do PCS.

Este efetivo também já era para conduzir as duas motocicletas e patrulhar utilizando o automóvel que seria exclusivo para as atividades de policiamento comunitário. Haveria o apoio motorizado de mais uma viatura que auxiliaria os postos policiais e realizaria paradas programadas em determinados pontos pré-estabelecidos, realizando o chamado radiopatrulhamento, dividindo as equipes entre os que realizavam o patrulhamento e os que realizavam o policiamento comunitário.

A diretriz número 01 de 27 de março de 2008 ainda determinava:

a. Oportunamente, serão criados mecanismos para avaliação sobre o andamento do funcionamento dos PCS implantados, de modo a ser buscada a máxima efetividade no desenvolvimento do serviço, servindo a experiência inicial como parâmetro para a ampliação dessa natureza de serviço a outras UPM, assim como 
a elaboração de documentos para fins de controle e padronização de procedimentos;

b. As Seções de Planejamento de cada UPM deverão elaborar, mensalmente, planilhas estatísticas de incidências criminais da área de responsabilidade de cada posto comunitário, para intensificação e orientação ao policiamento, adequando procedimentos para reverter situações que se sobressaem naquela área

c. A atuação de todo o efetivo será voltada à realização de frequientes contatos pessoais com a comunidade atendida, por meio de paradas (em pontos-base) em locais estratégicos selecionados para comporem roteiros de rondas e de patrulhamento.

d. O policiamento dos PCS, bem como as viaturas e motocicletas colocadas a disposição, atenderam exclusivamente às atividades de policiamento ostensivo comunitário, previstas para o setor definido, e não estarão à disposição da CIADE/SSP para fins de atendimento de ocorrências solicitadas pelo terminal de 190, ficando destinadas para esse tipo de serviço, as viaturas de rádiopatrulhamento de cada setor de policiamento.

e. Os Comandantes de Unidades deverão empregar nos PCS, os policiais militares que tenham participado dos $1^{\circ}$ e $2^{\circ}$ ciclos de palestras de Atendimento com Qualidade nos Postos Comunitários de Segurança e os que possuem os Cursos de Promotores de Segurança Comunitária, ambos realizados pela SSP/DF, e do Curso de Polícia Comunitária, promovido pela SENASP. Posteriormente, a filosofia de policiamento comunitário será amplamente difundida e implementada com diretrizes complementares a serem emanadas pelo Centro de Polícia Comunitária e Ações Sociais -CPCAS/PMDF.

f. Caberá a cada Cmt UPM baixar Normas Gerais de Ação (NGA) dos PCS implantados em suas respectivas áreas de 
responsabilidade, encaminhando cópia ao Estado Maior. (PMDF, DIRETRIZ 001/2008)

Por ser uma determinação, todas essas orientações foram seguidas pelos comandantes de unidade e transmitidas aos comandantes de PCS. Vários instrumentos foram criados para documentar a implantação da política, para avaliar a padronização das ações policiais e para produzir dados estatísticos de incidência criminal. Para tanto, disponibilizaram para os policiais os seguintes documentos:

a) Formulário de Atividade de patrulhamento: os policiais relatavam qual o tipo de patrulhamento (se era uma visita comunitária, patrulhamento ostensivo, atendimento de imediato, ordem de serviço da unidade policial, visita solidária, entre outros), como foi realizado o patrulhamento (a pé, carro, moto ou outro meio), quem foi responsável, em que setor e qual o objetivo do patrulhamento;

b) Formulário de visita comunitária: documento para registrar se o policial foi proativo, se estava acompanhando alguma solicitação feita pelo cidadão ou se foi solicitado pelo cidadão. Neste documento era possível registrar se a visita era em uma residência ou em um estabelecimento comercial, qual o nível de aceitação do policiamento comunitário (ótimo, bom, regular ou ruim) e as pendências solicitadas (policiamento, orientação/divulgação, jurídico/penal e outros). O policial também tinha a possibilidade de registrar a marcação de uma próxima visita;

c) Formulário de cadastro de liderança/entidade/organização: este documento registrava quem eram as lideranças locais com nome, endereço, telefones, endereços eletrônicos, quantos integrantes se fosse o registro de uma entidade, assim como o horários de funcionamento;

d) Formulários de abordagem a veículo e formulário de abordagem a pessoa: ambos registravam o nome do cidadão abordado, o local, o responsável pela abordagem e o motivo da abordagem.

Também havia os formulários criados pelos gestores para que os policiais preenchessem durante o atendimento. Como não era uma determinação, nem todos os 
gestores de postos ou comandantes das unidades criaram e, entre os que foram criados, as motivações e os dados foram diversos.

Em um destes formulários, havia a intenção em melhorar o atendimento e assim solicitavam aos cidadãos que foram atendidos que informassem se eram moradores, comerciantes, trabalhadores locais, estudantes; se avaliavam o serviço prestado pela PMDF à comunidade como ótimo, bom, regular ou fraco; se já haviam sido vítimas de crime, e se já foram vítimas que informassem em que horário e local; qual a preferência para acionar a PMDF, se por telefone, no PCS ou por uma viatura passando; se conheciam alguém que tinha sido vítima de crime nos últimos doze meses, em que local e hora; qual era o local mais perigoso da comunidade em que moravam; se a pessoa conhecia a filosofia de polícia comunitária; se consideram a iluminação e a pavimentação satisfatórias na comunidade; se a PMDF conseguira fazer a segurança pública sozinha; quais as outras instituições que poderiam contribuir com a melhoria da sensação de segurança local; se conhece o Conselho de Segurança da Cidade; e o que poderia ser para melhorar a segurança na comunidade (PMDF e cidadão).

Este formulário seria preenchido por um policial ao conversar com vítimas de crimes ou com cidadão durante as chamadas visitas comunitárias. Um policial praça informou que apenas dois policiais militares faziam o preenchimento dos formulários durante a ocorrência, o comandante do posto e o subcomandante, os chamados gestor e subgestor. Segundo este policial militar, com 30 (trinta) anos de serviço policial, os policiais entendiam que os relatórios eram trabalhosos e demoravam o preenchimento.

De certa forma, a quantidade de trabalho descrita nos relatórios era um instrumento de controle da atividade policial pela quantidade de ações realizadas por membros de cada posto. A subseção de Planejamento de cada unidade policial militar tinha a responsabilidade de tabular os dados e enviar relatórios de produtividade. Todavia, informações qualitativas se perdiam nas ações que não eram relatadas aos superiores hierárquicos.

Da mesma forma que apresentadas no projeto da campanha eleitoral, também estavam previstas as paradas em locais estratégicos. Para controlar a execução destas paradas, alguns gestores de unidades policiais criaram formulários para serem preenchidos para relatar o horário e o local em que foram feitas as paradas. Esta prática já fazia parte da cultura policial militar e era chamada de cartão programa (quando havia a obrigatoriedade de seguir um roteiro pré-determinado) e Ponto de Demonstração ou 
Papa Delta (quando havia a obrigatoriedade dos policiais militares ficarem em um lugar por um período pré-determinado ao lado da viatura para demonstrar vigilância).

Já a disponibilidade de viaturas foi realizada de forma improvisada, as viaturas provindas da compra do convênio com a SENASP/MJ ainda não estavam disponíveis. Os veículos disponibilizados, conforme os demonstrados na fotografia 1, eram veículos que estavam no patrulhamento da cidade e foram remanejados para atendimento no posto.

Também havia outro problema de ordem de recursos para cumprir esta determinação de disponibilizar a quantidade de motocicletas no posto policial. Por ter poucos policiais que patrulhavam com motocicletas, em alguns lugares foram remanejados todos os policiais para ficar apenas para o posto policial. Assim, não era possível, em alguns postos, que houvesse a permanência de duas motocicletas disponíveis para o policiamento comunitário.

Além da falta de policiais habilitados para conduzir motocicletas, havia a falta de instrumentos materiais para trabalhar. Mesmo firmado o convênio, os postos inicialmente não tinham computadores, sinal de internet, entre outros recursos. Em alguns lugares foram disponibilizados computadores que estavam em uso no quartel local para suprir a necessidade até que os computadores comprados fossem disponibilizados.

Um ano após a inauguração do primeiro PCS, em um ofício que respondia a uma mensagem que solicitava informações sobre a existência de aparelho fax, aparelho celular, rádio portátil, acesso à internet, computador, equipamentos de acesso à internet, impressora e copiadora a resposta da unidade policial foi $\mathrm{NÃO}$ para todos os itens. O único item em que foi dada a resposta SIM foi para o veículo que havia recebido em junho de 2009.

Todavia, com a instalação de vários postos ao mesmo tempo surgiu outro problema, maior, a falta de efetivo. A solução encontrada pelo comando da PMDF foi mudar as escalas de todas as modalidades de policiamento para $24 \mathrm{~h}$ (vinte e quatro horas) de serviço. Todos os policiais, mesmo os policiais que trabalhavam no patrulhamento das vias, mudaram a escala. Esta plantão de 24 h era próprio de serviço interno de guarda de instalações ou de postos rurais que tinha possibilidade de descanso por ter efetivo para revezar durante a noite e camas para descansar.

As equipes do posto passaram a ter de 03 (três) a 04 (quatro) policiais por dia, trabalhando 24h. Assim, durante o dia, caso houvesse ocorrência para ser atendida, ficava o gestor e o subcomandante do posto realizando as atividades de policiamento 
comunitário enquanto as viaturas (automóvel e motos) realizavam o cumprimento da determinação de fazer patrulhamento em determinadas rotas e parar em lugares específicos. Durante a noite, ficava um policial no posto enquanto os outros dois ou três atendiam ocorrências.

Durante o trabalho policial ordinário, fui remanejado de setor e fui escalado para trabalhar conduzindo as motocicletas nos postos comunitários justamente pela falta de policiais habilitados, o horário era de $13 \mathrm{~h}$ às $19 \mathrm{~h}$, todos os dias, de segunda a sábado. Todos os policiais, tanto os policiais de patrulhamento quanto os policiais motociclistas mudariam as escalas para um plantão de $24 \mathrm{~h}$.

Esta mudança abrupta de horário deixou a maioria dos policiais descontentes. Muitos policiais organizaram as atividades privadas com horários fixos. Levar filhos à escola, trabalhar em um segundo horário, estudar, entre outras atividades, estavam organizadas de acordo com a escala de serviço que já era fixa há anos. A primeira resistência foi o horário pelas questões privadas.

A segunda resistência ao horário foi em relação à estrutura do PCS. Diferentemente do projeto da campanha eleitoral e de alguns postos policiais que já funcionavam nas regiões administrativas, os postos não dispunham de banheiros com chuveiro, locais para descanso e camas. A sala pequena, com apenas um banco de metal e um balcão para atender ao público, não oferecia o conforto suficiente para ficar vinte e quatro horas no posto.

Foi neste momento que senti, juntamente com os outros policiais militares, muito calor durante o dia e frio durante a noite. $\mathrm{O}$ isolamento térmico projetado para o posto não era suficiente para não permitir que acumulasse gotículas de água no teto do posto durante a noite em determinadas épocas. E o ventilador também não refrescava o suficiente durante o dia. Os patrulheiros das viaturas ainda podiam sentar nos bancos da viatura que ficava no posto, já os motociclistas, o que era meu caso, não tinham a mesma possibilidade durante a noite. Assim, eu solicitava aos demais policiais militares para sentar no interior da viatura a procura de proteção do frio.

Já o terceiro motivo da resistência ao horário é que, para a maioria dos policiais militares que tive a oportunidade de entrevistar, trabalhar vinte e quatro horas era muito desgastante e, na madrugada, depois de 15 (quinze) horas de serviço sem descanso, patrulhando e atendendo durante o dia, não teria a mesma condição psicológica para 
atender ao público, para atender uma ocorrência e, em último caso em algumas ocorrências, ter uma decisão em frações de segundo se deveria atirar ou não, por exemplo.

Assim, o início da implementação da política de segurança pública do Policiamento Comunitário pelos PCS, para os policiais militares, teve a sua primeira associação com a mudança da rotina da vida privada, obrigar trabalhar em um espaço que não oferece conforto e trabalhar com um estresse a mais. Aceitar os postos comunitários e a mudança da forma de trabalhar era aceitar todas estas mudanças. As primeiras falas dos policiais entrevistados dizendo que estes postos iriam virar pontos de entrega de pão e leite do governo demonstraram qual o futuro que estaria se construindo pelo olhar dos policiais.

\subsection{O Habitus e as Práticas Institucionais}

Um outro vértice da nova política de segurança era a mudança da cultura policial militar. Como foi salientado, a instituição Polícia Militar é uma instituição total que, a partir de vários processos de constituições de identidade, a identidade Policial e identidade Militar tem maior projeção sobre as demais, sendo orientado pelo habitus (BOURDIEU, 2006). O Campo do controle do delito, assim, tem grande influência sobre as práticas cotidianas do policial militar.

Todavia, como salientado anteriormente, o campo de controle do delito é um campo social que está se moldando com instituições militares e civis em busca de constituir um objeto próprio que é a Segurança Pública. O que é comum até então às instituições é o ethos guerreiro de combate ao crime e ao criminoso.

Entretanto, como ainda está em constituição o conhecimento específico no campo social, composto por instituições civis que são responsáveis pelo fluxo e segurança nas vias públicas (DETRAN e DER), por instituições militares ou composta por militares que são responsáveis pela prevenção de acidentes e resgate (CBMDF e Defesa Civil), por instituições miliares e civis que são responsáveis pela prevenção e repressão ao delito (PCDF e PMDF), a forma em que este ethos é interiorizado é de forma diversa. 
Essa mesma diversidade de interiorização e/ou socialização do ethos guerreiro também está presente na PMDF. Diante da diversidade de trabalho e especializações que a instituição tem, pôde-se perceber que as unidades policiais militares do Distrito Federal têm algumas características próprias, resultado das interrelações entre policiais militares e destes com a comunidade local. Assim, há unidades que são mais "militares" e há unidades que são mais "operacionais".

Outro fator importante para a compreensão ao analisar a implementação da política de segurança e, por conseguinte, analisar a aderência da política à instituição, é a geração em que o indivíduo foi socializado na instituição. Há um código entre os policiais para identificar qual a geração de formação do policial quando se pergunta: qual a sua matrícula.

Quando o novinho ingressa nos quadros da PMDF, ele recebe uma matrícula de identificação. Inicialmente esta "marca" era gerada na própria instituição, a partir do primeiro que ingressou. Posteriormente, o número foi gerado pela instituição de gestão do GDF, que gerencia todos os servidores públicos.

As turmas de formação de praça na PMDF são compostas de um grande quantitativo de militares. Muitos cursos de formação tiveram mais de mil alunos no mesmo processo de socialização. E como não há a prática na PMDF de realizar cursos em um intervalo regular, as turmas ficam marcadas por políticas de formação policial ou por determinados contextos políticos.

Dessa forma, as turmas foram nomeadas pelos policiais militares para se auto identificarem no tempo e no espaço. Assim, há as turmas conhecidas como $4^{\mathrm{a}}$ série e turmas $4^{\mathrm{a}}$ séries fortes que referem à geração de policiais militares que ingressaram na instituição no tempo quando era exigido somente até a então $5^{\mathrm{a}}$ série do $1^{\mathrm{o}}$ grau (quarto ano da educação básica); há a geração Robocop ou Policiais do futuro, que foi a primeira turma a exigir a conclusão do então segundo grau, o ensino médio, mais conhecida como os 23 ou 24.000; a geração todynho, de que foi exigida a conclusão do ensino superior para o ingresso na instituição; entre outras gerações que ingressaram com a mesma escolaridade, mas que se destacaram por algum contexto político ou da formação.

Cada geração é identificada com um grupo de matrícula, de forma aproximada. Assim, os números de matrícula 12.000 aos 14.000 tem uma representação simbólica na instituição, da mesma forma que os 18.000 , os 24.000, os 170 milhões, os todynho tem outra representação, e assim por diante. 
Quando terminei o curso de formação de soldado, em 2000, o então Governador Cristovam Buarque havia falado em uma entrevista que estaria formando os Policiais do Futuro. O curso de formação foi de quase um ano e pela primeira vez uma turma da PMDF ingressava com a exigência de concluir o ensino médio, sendo que aproximadamente $30 \%$ já havia concluído o ensino superior. Após o curso, ao chegar na minha primeira unidade para trabalhar, percebi o quanto aquela marca de policial do futuro, ou Robocop para outros policiais, diminuiria meus acessos aos grupos de policiais mais antigos porque nossa turma de 23.000 e 24000 foi pichada naquela unidade como a turma que iria separar o joio do trigo. O processo de adaptação ao grupo foi lento e cercado de desconfianças de ambos os lados.

Já as turmas de oficiais também tem sua marca. Eles se autoidentificam por número da turma. As praças também há a numeração por turma, mas é muito raro lembrarem de qual turma é. Os oficiais prezam a numeração da turma para se identificarem com quem tem a formação oriunda do Exército Brasileiro, que são os oficiais conhecidos pelos policiais militares como $R 2$, ou da Academia de Polícia de Brasília, a escola de oficiais própria da PMDF que a partir da década de 90 inicia a própria formação de oficiais, colocando fim ao fluxo de oficiais indicados pelo Exército para compor os diversos quadro da instituição. A matrícula dos oficiais, como processo de identificação, tem maior importância para as praças para identificar aqueles policiais que foram praças e reingressaram nos quadros dos oficiais.

Assim, geralmente quando um policial militar pergunta a outro "Você é quantos mil? " a resposta traz consigo de qual geração que o policial é, sendo possível identificar quando ingressou, quem foram os seus comandantes durante o curso ou a doutrina que seguiu, quanto tempo teve o curso, o que fez durante o curso (não há uma norma na instituição de regulamente quanto tempo do curso de formação para as praças), o que fez assim que terminou o curso, entre outras características.

As primeiras gerações foram socializadas com um treinamento mais militar e durante pouco tempo de curso. Se fosse possível medir o peso do militarismo e da prática policial, pode-se dizer que são mais militares que policiais. Há outras gerações em que o militarismo ainda tem uma marca forte na formação, mas há uma tentativa de tentar diminuir o empirismo e tentar valorizar os conhecimentos socializados nas escolas de formação. 
A política de segurança pública que tenta implementar o policiamento comunitário tinha a perspectiva de mudar os currículos de formação das praças e dos oficiais e seguir a orientação da SENASP/MJ de incluir nos currículos a disciplina Policiamento Comunitário. Esta mudança de doutrina e tentativa de mudança cultural foi internalizada de diferente formas. Segundo um subtenente da instituição com aproximadamente 34 (trinta e quatro) anos de serviço na PMDF, gestor de um PCS, a introdução do policiamento comunitário nas práticas esbarra na aceitação de determinados grupos

[...] A dificuldade que a gente encontra mais é o próprio policial mesmo, o policial do Distrito Federal a maioria é uma tropa antiga e já tem aqueles vícios, vícios dos mais antigos, então é complicado pra trabalhar com policiamento comunitário porque muitos policiais não concordam em ter muito contato com a população, é o policial acostumado mais é só em atender ocorrência mesmo, né, é fazer o atendimento, conduzir pra DP e fazer os registros - mas aqueles propósitos mesmo do policiamento comunitário de fazer visita comunitária, fazer a visita solidária, fazer aqueles contatos diários... é difícil trabalhar. (Sargento com 34 anos de serviço policial militar)

Além da identificação entre gerações, que pode ser um indicador de chance de internalizar e de apropriação da nova política de segurança que pretende mudar a cultura policial, ainda não representa nuanças tal qual a divisão entre policiais comuns e policiais especiais. Ser um comum é ser o policial que atende ocorrências cotidianamente, que realiza o trabalho ordinário de patrulhar as ruas, de atender o cidadão nos postos (comunitários ou não como, por exemplo, nos postos que estão nos hospitais), de controlar o fluxo de veículos e pedestres, de atender ocorrências Maria da Penha ${ }^{26}$ ou de

\footnotetext{
${ }^{26}$ As ocorrências de violências domésticas são tipificadas informalmente pelos policiais militares como ocorrências Maria da Penha. Alguns policiais evitam estas ocorrências, pois havia uma grande probabilidade da vítima retirar a denúncia e posteriormente o agressor registrar queixa contra o policial por violência. Após a lei conhecida como Maria da Penha, esta prática mudou, todavia, não há mais a possibilidade de retirar a denúncia e os policiais militares desenvolveram práticas para se respaldar durante a abordagem e a condução à delegacia, todavia, muitos policiais relatam que que é um trabalho improdutivo, já que as mulheres violentadas não conseguiam sair do ciclo da violência.
} 
som alto durante a noite, atender conflitos de vizinhos, entre outros tipos de ações que foram destacadas por vários estudos acerca do trabalho (MUNIZ, 2002; BAYLEY, 2006; RAMOS e MUSUMECI, 2005; BRITTNER, 2003) que demonstram que a atividade policial ostensiva consiste muito mais do que realizar prisões.

Assim, há vários gradações de ser um policial especial ou operacional na PMDF. Apesar de ter no Departamento Operacional um Comando de Missões Especiais em que todas as unidades realizavam policiamento especializado como, por exemplo, o policiamento ambiental, de trânsito, o policiamento em área escolar, o policiamento aéreo e o policiamento montado a cavalo, são alguns componentes do Batalhão de Operações Especiais que tem o maior capital social na PMDF quanto a operacionalidade policial.

Os policiais caveirados ou os caveiras são os policiais que têm o Curso de Operações Especiais e são capacitados para desenvolver atividades em alto grau de estresses e periculosidades. A farda preta, os distintivos em forma de caveira representando o curso, entre outras características simbólicas identificam e distinguem quem tem acesso ao seleto grupo de especiais (diferente de "simplesmente" especializados).

Assim, há uma representação social da Operacionalidade, do ser especial. Esta representação tem gradações e está constituída nas unidades policiais militares e em seus membros. Como destacado anteriormente, membros "caveirados" do Batalhão de Operações Especiais estariam no ápice desta representação, seguidos dos membros não caveirados, mas pertencentes ao Batalhão, nesta segunda categoria estão os policiais que trabalham nas PATAMOS (Patrulhas Táticas Moveis), que sãos os policiais militares que realizam patrulhamento, em comboio, pela cidade.

A segunda unidade reconhecida pelos policiais como operacionais na PMDF é a ROTAM (Rondas Táticas Móveis). Esta unidade "rivaliza" com as PATAMOs em ditar quais as doutrinas policiais, os procedimentos de abordagens, as técnicas de manuseios para determinados tipos de armas, entre outros códigos que distinguem os grupos. Adotar o codinome de Joe ou Steve identifica se você é da PATAMO ou da ROTAM, respectivamente. O uniforme dos membros da ROTAM é um camuflado urbano. Geralmente também seus membros patrulham em comboio, com 03 (três) ou 04 (quatro) viaturas e com 03 (três) ou 04 (quatro) policiais em cada viatura. O armamento das duas unidades são semelhantes: metralhadoras, fuzis, pistolas, armas menos letais, entre outras. Todavia, somente o Comandante da ROTAM chamava seus subordinados de caçadores. 
O Tenente Coronel comandante da ROTAM fez esta distinção do seus comandados para tentar marcar o seu grupo como os "caçadores de criminosos", apreendedores de armas e de entorpecentes ilícitos.

As duas unidades, o BOPE (que inclui a PATAMO) e a ROTAM, têm como área de patrulhamento ou policiamento todo o Distrito Federal. Todavia, o BOPE é percebida pelo alto comando da PMDF como uma tropa disciplinada e de confiança, saindo para patrulhar apenas em algumas missões pré-determinadas. Já a ROTAM, que também tem como área de policiamento toda a região do Distrito Federal, patrulha diuturnamente, inclusive em apoio aos policiais das unidades das regiões administrativas.

As unidades ordinárias, que são as unidades responsáveis pelo policiamento de cada região administrativa, também têm o seu grupo especializado. Há, por exemplo, os grupos táticos, os chamados GTOP (Grupos Táticos Operacionais). Esses grupos são treinados pelos policiais da ROTAM, têm armamento semelhante aos das outras unidades, todavia, patrulham somente a cidade em que seu batalhão se localiza. O fardamento é o chamado Operacional, um fardamento Azul com boina para distinguirem dos policiais da própria unidade. Também utilizam o símbolo do Raio para representar o Grupo Tático local.

Além destes, há os policiais comuns que são os policiais que realizam o policiamento que atende o maior número de ocorrência e a maior diversidade. Ocorrências de conflito entre vizinhos, perturbação da paz, pessoas desaparecidas, violência doméstica, maus tratos, acidentes de trânsito, furtos, roubos, uso e/ou tráfico de entorpecentes ilegais, porte ilegal de arma, entre outros. Destaco esses tipos de ocorrências atendidas pelos policiais comuns porque os grupos táticos são acionados, geralmente, em ocorrências que demandam um quantitativo maior de policiais ou há um maior risco à vida, como ocorrências em que há porte de arma. No fardamento dos comuns não há símbolos de cursos que outros policiais possam ter, da mesma forma há poucas medalhas. São os policiais comuns que são mais conhecidos nas áreas de patrulhamento e que desenvolvem o maior número de rondas. $\mathrm{O}$ armamento, geralmente, é uma pistola e uma tonfa ou bastão retrátil.

Continuando a gradação de representação da operacionalidade, há os policiais $d o$ expediente. Estes policiais são os policiais que desenvolvem as atividades meio nas seções das unidades policiais militares. Diferentemente dos outros policiais, são os policiais que trabalham de segunda a sexta-feira, no interior dos quartéis, no período 
vespertino. Assim, folgam finais de semanas, feriados, como a maioria dos outros trabalhadores não policiais. Muitos trabalham desarmados e só trabalham na "rua" esporadicamente como, por exemplo, no carnaval, no natal, entre outros eventos na cidade. Todavia, nem todos trabalham porque há policiais de expediente baixados, isto é, que estão com restrições de saúde e não podem mais desenvolver atividades de policiamento ostensivo, somente nas atividades meio.

Além de todos estes, há o policial muxiba. Este é o policial que, independente do trabalho, se de rua ou de expediente, não desenvolve suas atividades intencionalmente, atrapalhando deliberadamente o trabalho dos outros policiais por ter que acumular trabalho.

Destaco estas gradações porque nelas estão implícitas a construção pelos policiais militares do perfil ideal de policial militar no Distrito Federal. Assim, quanto mais adquirir capitais simbólicos para se aproximar deste perfil, mais reconhecimento tem na instituição. Quanto mais "caçador", quanto mais arma apreendida, entorpecente ilícito apreendido, quanto mais prisões flagrantes forem realizadas, maior o reconhecimento entre os demais. Seja praça ou oficial, ter a matrícula iniciada com 10.000 (dez mil) ou 200.000.000 (duzentos milhões), ter ingressado com "a quarta série forte" ou ensino superior, independente de gênero, a construção e o capital simbólico é o mesmo.

Nos quarteis das unidades policiais militares há três galerias de honra. Uma é dos ex-comandantes da unidade. A outra é de melhores policiais militares do mês ou do ano. E a terceira, caso haja, dos policiais mortos em serviço. São os policiais tombados em serviço policial que recebem todas as honras militares. Por ser um típico suicídio altruísta, (DURKHEIM,2000b), é um ritual para renovar os valores do grupo e o ethos guerreiro.

Com a política de segurança pública de implementar o policiamento comunitário, há uma outra categoria fora da gradação do ethos guerreiro que privilegia essencialmente a não ocorrência do crime que é a variável quantificável ou a possibilidade de acúmulo do capital simbólico que legitima o status de ser um bom policial ou que dá a possibilidade de reconhecimento para todos e todas policiais.

Assim, com a implementação da nova política de segurança pública, há uma proposta de mudança de habitus e de capital simbólico do campo de controle social. É uma mudança que alteraria as práticas diárias de policiamento e privilegia um outro conhecimento que antes estava desprivilegiado por "não produzir", por não apreender armas ou entorpecentes (porque a não ocorrência de crime que é o desejado). A possível 
sensação de segurança produzida pela prevenção não deixava rastro quantificável, assim, os policiais não quantificáveis estavam no rol dos policiais que eram os muxibas.

Portanto, a nova situação criou um sistema híbrido na estrutura policial militar em que conviviam dois principais sistemas de valores que outorgavam distintos conhecimentos e diferentes formas de reconhecimento. A implementação da política de segurança pública, introduzindo novos valores que eram típicos da doutrina de policiamento comunitário, não deslegitimou o conhecimento que assegurava o reconhecimento do perfil do policial militar desejado.

Esse sistema híbrido ficou nítido na estrutura administrativa da PMDF, centralizando o comando das ações do policiamento comunitário no Centro de Polícia Comunitária e Ações Sociais (CPCAS) que posteriormente foi reestruturado e nomeado Centro de Polícia Comunitária e Direitos Humanos (CPCDH).

Como demonstrado na figura 10, que representa o organograma da PMDF, ao ser incorporado o policiamento comunitário, em que o $\mathrm{CPCDH}$ teve um status de assessoria do comandante, semelhante ao status das diretorias da PMDF

Figura 10- Estrutura Organização da PMDF, nível Departamentos e Diretorias

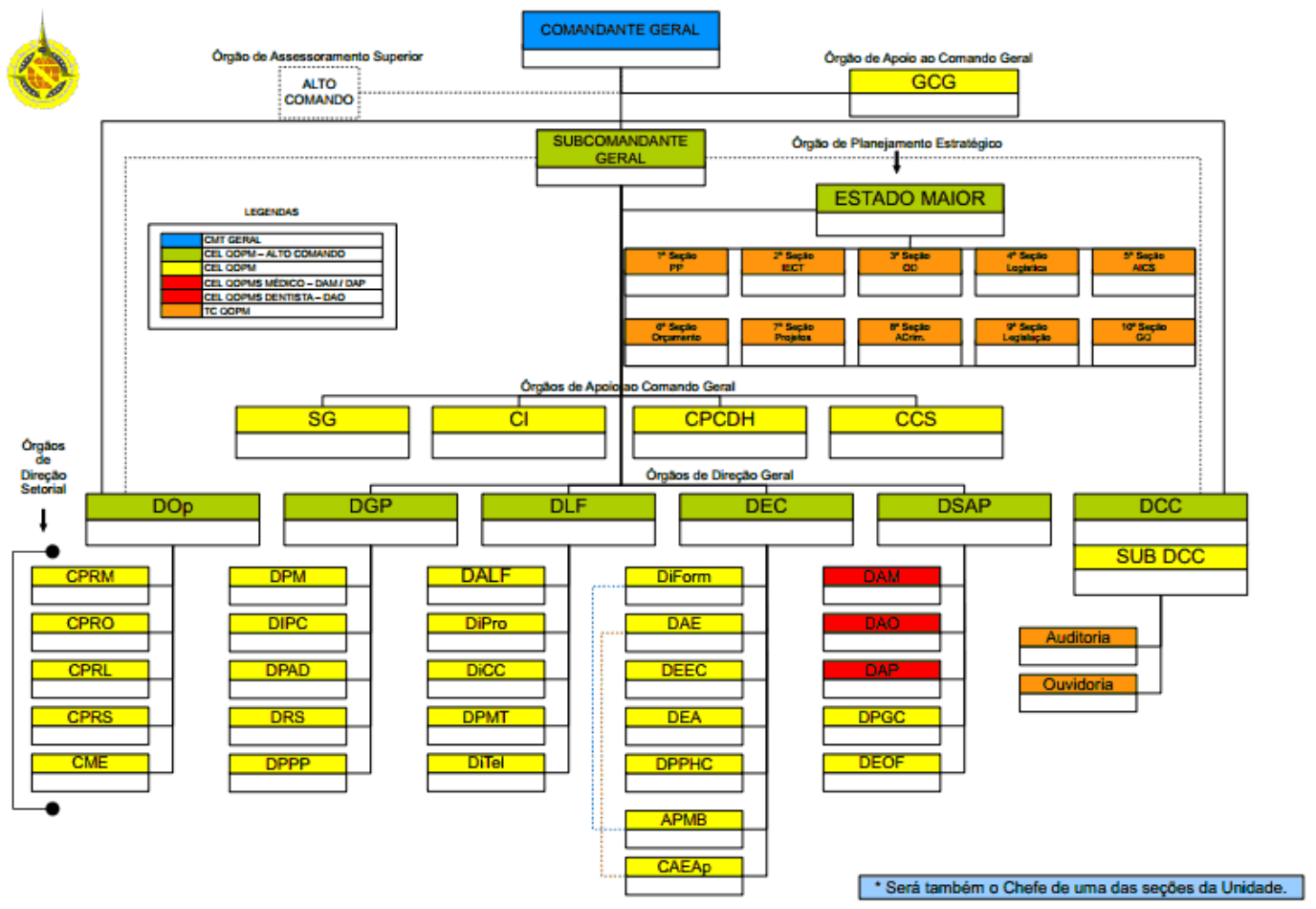

Fonte: PMDF, 2010 
Esse sistema híbrido ficou ratificado na Diretriz 01 de 2008 da PMDF e no Decreto número 31.793 do Governo do Distrito Federal, de novembro de 2010. Neste decreto determina qual a estrutura organizacional da PMDF, quais as competências de cada unidade policial militar, seja esta unidade um batalhão de policiamento, uma diretoria, um departamento ou uma unidade de saúde. Assim, podemos destacar as duas partes deste sistema híbrido na estrutura administrativa que iniciava a tentativa de mudança das práticas policiais.

Primeiramente, o Centro de Polícia Comunitária e Direitos Humanos é responsável por assessorar o Comando da instituição na implementação e consolidação da filosofia de policiamento comunitária e de direitos humanos e estava subordinado diretamente ao Subcomandante da PMDF (DISTRITO FEDERAL, 2010).

Esta unidade administrativa tinha três divisões: uma para desenvolver atividades que consolidassem o respeito aos direitos humanos individuais e coletivos; outra divisão para consolidar a prática do policiamento comunitário na instituição e outra para desenvolver atividades que estivessem voltadas para o desenvolvimento de programas sociais preventivos de segurança pública.

Como competência, o decreto determinava que o $\mathrm{CPCDH}$ deve:

I - assessorar o Subcomandante-Geral nos assuntos relativos à polícia comunitária, direitos humanos e ações sociais;

II - planejar e orientar as atividades de polícia comunitária e ações sociais;

III - propor doutrinas e políticas de polícia comunitária e de direitos humanos na PMDF;

IV - propor ao Departamento de Educação e Cultura os conteúdos necessários aos cursos de formação e aperfeiçoamento, em todos os níveis;

V - elaborar propostas que vise a fixação de doutrinas e de mudança organizacional baseada na filosofia e na criação de ambiente favorável à implementação e desenvolvimento da Polícia Comunitária, bem como, à realização do policiamento em todas as modalidades. 
Segundo estas diretrizes, o CPCDH não comandaria os policiais diretamente. Todavia, seguidamente, os gestores dos PCS's realizavam reuniões com o comandante do Centro de Policiamento Comunitário para delinear e padronizar ações. Foram nestas reuniões que ficaram acertados os formulários que seriam preenchidos pelos policiais dos postos, como e quando seriam os diversos tipos de visitas, quais as ações de prevenção que poderiam ser desenvolvidas, debates de ações que foram bem recebidas pela comunidade, entre outros assuntos que tangenciavam a doutrina de policiamento comunitário que a PMDF estava pretendendo consolidar.

Uma das decisões tomadas referia-se ao uso das viaturas que estavam à disposição para os policiais no postos policiais. O uso da viatura era simbólico para representar o hibridismo do policiamento comunitário/repressivo da PMDF. As viaturas destinadas ao policiamento comunitário ficavam nos postos comunitários reservadas aos policiais para desenvolverem as visitas, participarem de reuniões com a comunidade, entre outras atividades. Não podiam atender ocorrências ou serem utilizadas para outras ações.

Esta decisão já estava respaldada na Diretriz 01 de 2008, no que dizia

O policiamento dos PCS, bem como as viaturas e motocicletas colocadas a disposição, atenderam exclusivamente às atividades de policiamento ostensivo comunitário, previstas para o setor definido, e não estarão à disposição da CIADE/SSP para fins de atendimento de ocorrências solicitadas pelo terminal de 190, ficando destinadas para esse tipo de serviço, as viaturas de rádiopatrulhamento de cada setor de policiamento.

Os policiais militares lotados nos PCS estavam subordinados ao comando da unidade da região administrativa, todavia, seguiam recomendações ou determinações do Centro de Policiamento Comunitário, seção esta que ficava Quartel General da PMDF, em Brasília, região metropolitana. Em média, dezesseis policiais de PCS recebiam recomendações de outro comandante, geralmente um Coronel, que estava a 30 (trinta) quilômetros de distância (média de distância das regiões administrativas em relação a Região Metropolitana) e estavam "ligados" pela nova doutrina que estava sendo estabelecida. Para cada posto instalado, o controle deste Coronel aumentava e a 
possibilidade de mudança de prática policial mudava de acordo com a quantidade de aderência que os novos policiais incorporados à nova filosofia era feita. É mais uma vértice do conflito da policiamento comunitário com a outra parte do sistema híbrido, a correlação de forças entre os grupos dos oficiais que seguem doutrinas diferentes e defendem posições diferentes de qual a solução para a criminalidade ou redução do crime: se a prevenção pelo policiamento comunitário ou o combate pelo policiamento tradicional.

A segunda parte deste sistema híbrido está relacionada às práticas tradicionais de policiamento ostensivo desenvolvidas pelos policiais que estavam sob o comando do Departamento Operacional (DOp), alinhadas ao perfil tradicional de policial ideal. Diferentemente do chefe do Centro de Policiamento comunitário, o chefe do Departamento operacional é um Coronel, que faz parte do alto comando e está responsável pelo policiamento ostensivo em todo o Distrito Federal, seja planejando, coordenando, fiscalizando e controlando os comandos de policiamento regionais para a uniformidade das ações, a disciplina e o emprego operacional (DISTRITO FEDERAL, 2010). Para tanto, no artigo 71 do decreto, há as seguintes atribuições:

I - elaborar o Plano Geral de Polícia Ostensiva e de Preservação da Ordem Pública no Distrito Federal e o Plano de Articulação Operacional da Polícia Militar do Distrito Federal;

II - gerir o emprego da polícia ostensiva e da preservação da ordem pública no Distrito Federal;

III - estabelecer metas e objetivos operacionais mensuráveis para os comandos subordinados, observadas as diretrizes do planejamento estratégico da Polícia Militar do Distrito Federal;

IV - fiscalizar o cumprimento das metas e resultados definidos no Planejamento Estratégico da Polícia Militar do Distrito Federal;

V - elaborar os planos e ordens operacionais, bem como baixar diretrizes e orientações necessárias à sua execução e ao funcionamento dos órgãos subordinados;

VI - atribuir responsabilidade de comando pelas operações policiais militares que envolvam a atuação de mais de um comando subordinado; 
VII - elaborar proposta orçamentária anual do Departamento Operacional.

Portanto, as atribuições do Departamento Operacional estão voltados para a reificação das práticas policiais militares tradicionais. Para isso, tem sob seu comando os Comandos Regionais que comandam as unidades operacionais de cada região administrativa, conforme a figura abaixo:

\section{Figura 11Estrutura do Departamento Operacional da PMDF}

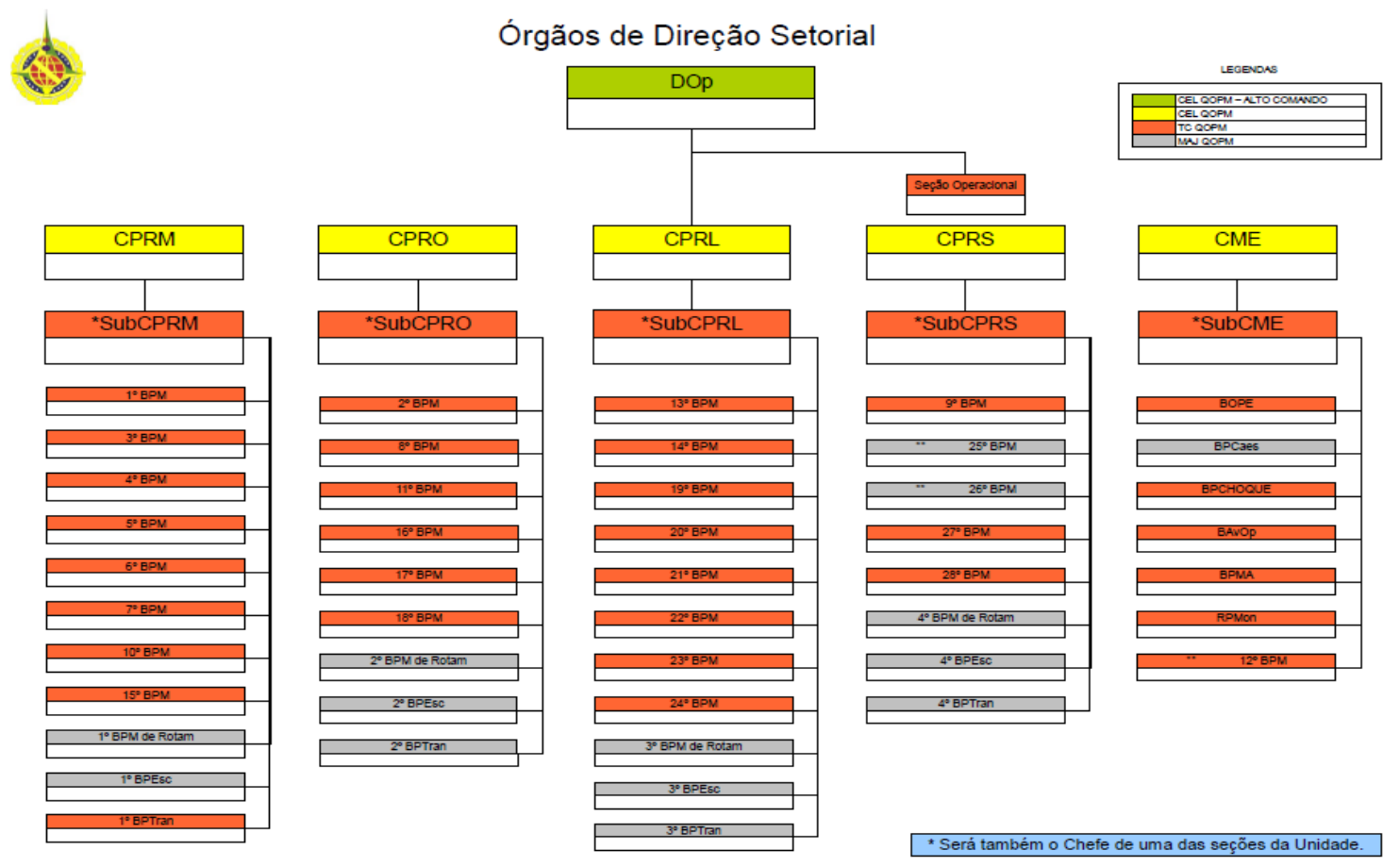

Fonte: PMDF, 2010

Conforme a figura, o Chefe do DOp, responsável pelo Plano de Policiamento da instituição, comandava diretamente cinco coronéis chefes dos comandos regionais, que comandavam todas as unidades operacionais do Distrito Federal. Suas determinações atingiam uma cadeia de comando bem maior e com maior poder de responsabilização.

Curiosamente, o mesmo prédio anexo ao Comando Geral abriga tanto o Chefe do Departamento Operacional quanto o chefe do Centro de Policiamento Comunitário e Direitos Humanos, a sala de recepção de cada um está lado a lado com a do outro. A distância geográfica destes com os policiais que realizam o policiamento nas ruas e nos postos é a mesma, todavia, as determinações do Chefe do DOp têm maior capilaridade 
porque a cadeia de comando as torna mais presentes, fiscalizando e ordenando ações diárias e estão direcionadas para um maior quantitativo policial.

Apesar de que em quase todas as regiões administrativas foram instalados PCS, em nenhuma delas havia puramente o policiamento comunitário, mas o sistema híbrido, em que determinados policiais não patrulhavam e determinados policiais não realizavam policiamento comunitário. Determinados policiais trabalhavam "produzindo" ao atender ocorrências, segundo a lógica até então construída, enquanto outros policiais nos PCS para atender a comunidade. O conflito de construção do ethos reverbera na prática cotidiana.

No Posto que eu trabalhava, ao ser remanejado para trabalhar como motociclista, houve um período em que fomos proibidos de rondar com as motocicletas e os automóveis. A determinação era que saíssemos apenas por solicitação da comunidade. Esta determinação perdurou por aproximadamente um mês. Assim, ficávamos no posto "vigiando" as instalações enquanto o gestor e o subgestor do posto saíam para fazer visitas e conversar com os comerciantes, e os outros policiais comuns e do tático patrulhavam o setor. Eu já tinha feito um curso de policiamento comunitário oferecido pela SENASP aos policiais militares do Brasil.

Este curso fazia parte do fluxo de soluções da SENASP e era realizado por força de convênio entre a Secretaria de Segurança do Distrito Federal estabelecendo que os policiais militares fariam vários cursos na modalidade à distância. Além do curso de Promotor de Policiamento Comunitário, realizei os cursos de técnicas de abordagem, fundamentação jurídica, Direitos humanos, entre outros, totalizando mais de 30 (trinta) cursos de curta duração.

Em 2008 participei de um processo seletivo de um convênio entre a SSP/DF e a SENASP/MJ para participar do Curso de Pós-Graduação Latu Sensu de Especialização em Segurança Pública e Policiamento Comunitário oferecido pele Universidade do Sul, em Santa Catariana, na modalidade à distância. Após o processo seletivo, que consistia em uma prova versando sobre conteúdos pré-definidos e uma redação, fui selecionado formando um grupo de 30 (trinta) servidores públicos do Distrito Federal, consistindo entre agentes e delegados da Polícia Civil, agentes de trânsito do DETRAN e oficiais e praças da Polícia Militar e do Corpo do Bombeiro.

Até aquele momento, minha percepção sobre policiamento comunitário era semelhante aos dos policiais que simpatizavam com a teoria recente sobre policiamento 
comunitário. Mesmo sabendo da desmotivação e resistências dos policiais que trabalhavam com a nova política pelas mudanças, percebia que aqueles policiais que não tinham tanto capital simbólico dos campos de controle estavam mais abertos a conquistar novos capitais.

A plataforma da SENASP/MJ oferecia vários cursos, entre eles, os de Promotor de Policiamento Comunitário. Segundo o Subsecretario Normando, os cursos frutos do convênios começaram ser realizados. Suas redes pessoais permitiram que ele conseguisse mais vagas.

O então tenente Oficial 1 fez um curso de multiplicador de Polícia Comunitária que o credenciava a ministrar aulas financiadas pela SENASP/MJ. Vários outros policiais, entre praças e oficiais, também puderam ministrar aulas da mesma forma que o então Tenente. Assim, profissionais de segurança pública podiam ministrar cursos para a própria agência de segurança nos horários de folga e recebiam do Governo Federal.

Por conhecer o então Coordenador de Polícia Comunitária da SENASP/MJ, Major Oficial $4^{27}$, conseguiu que as cotas de outras unidades da federação fossem remanejadas para o Distrito Federal.

Ele pegou todos os cursos que foram disponibilizados para todas as outras unidades da federação que o pessoal não fez, não pediu, porque era assim ligava pra SENASP e dizia "Quero fazer tantos, dez cursos, 12 cursos, 20 cursos", e a SENASP disponibilizava; depois você falava "Não vou mais fazer dez, vou fazer só oito ou vou fazer só sete", e quando a gente estava no primeiro ano com essa incumbência de mandar o máximo de policiais pra sala de aula pra fazer o curso de Promotor de Polícia Comunitária liguei para o Pitta e ele mesmo saiu ligando estado por estado perguntando "Vai fazer todos os cursos pessoal?" "Não" "Quantos?" "Então dois eu vou devolver", e aí todos os outros que não foram feito ele mandou pra gente, então no primeiro ano

\footnotetext{
${ }^{27}$ O Oficial 4 comandou unidades de policiamento ordinário em várias Regiões Administrativias, trabalhou em várias diretorias e departamentos da PMDF e em outras instituições do Distrito Federal e da União.
} 
a gente conseguiu fazer muito graças ao apoio dele lá (Normando, ex-subsecretário da SUPROC)

Ter a "pessoa certa no lugar certo" auxiliou a intensificar o processo de disseminar o conhecimento sobre Policiamento Comunitário. O financiamento do convênio auxiliou que praças e oficiais tivessem maior conhecimento sobre a doutrina policial. Os cursos presenciais também foram ofertados e com maior capilaridade. Os cursos não presenciais na plataforma $\mathrm{EaD}$ possibilitavam fazer dois cursos simultaneamente e muitos policiais os realizaram também.

Além do aumento de cursos oferecidos e realizados, da capilaridade da doutrina que começava a diminuir as resistências para fazer, muitos policiais começaram colocar os cursos sobre policiamento comunitário como segunda opção.

Os cursos de aperfeiçoamento, próprios da formação profissional continuada, também mudaram suas grades, e mesmo que os currículos ocultos pudessem dizer o contrário, o contato e o primeiro passo para desmistificar a doutrina de policiamento comunitário foi dado. Um dos pilares começava a ser construído com a possibilidade da mudança das práticas policiais.

Todavia, os conhecimentos e os debates presenciais e virtuais do curso não estavam alinhados com as práticas que se vivenciava nos PCS. O gestor do posto que eu trabalhava, um dos sargentos com mais tempo de serviço na unidade, já havia feito alguns cursos de policiamento comunitário, todavia, não sabia se sua percepção sobre o que era policiamento comunitário era a mesma da minha. Aliás, até aquele momento, eu não sabia se todos os que trabalhavam no policiamento comunitário ou que fomentaram a política de segurança pública e implantaram tinham a mesma percepção de policiamento comunitário. Apesar da disciplina hierárquica militar, os comandantes locais, comandantes de companhias e comandantes de postos conseguem uma "flexibilidade oculta" ${ }^{28}$ aos controles dos superiores para realizar suas atividades. Assim, mesmo com as portarias superiores, diretrizes da PMDF e da SSP/DF e das políticas do Governo da Unidade Federativa, os agentes de segurança interpretam e buscam operar as ordens dentro de uma discricionariedade. Esta flexibilidade oculta é uma relação de permissão

\footnotetext{
${ }^{28}$ Conceituamos de flexibilidade oculta no militarismo o limbo entre a regulamentação militar, a obediência à cadeia de comando rígida e a discricionariedade que a administração pública e o serviço policial exige para decidir e agir.
} 
do superior hierárquico para que faça algo, na esfera administrativa ou no serviço policial ostensivo, mas desde que esta ação não coloque em risco a posição do superior.

Em conversas enquanto ficava no posto, parado para receber os cidadãos que se deslocavam para o posto durante o trabalho policial, conversei com o gestor para que fizéssemos um jornal informativo do posto com tiragem mensal. A ideia era informar à comunidade sobre o que era a nova forma de policiamento e apresentar o posto. A ideia foi bem recebida e começamos a trabalhar no projeto. Ele se propôs conseguir financiamento para impressão e distribuição. O jornal teria quatro páginas com sete seções: conheça o posto comunitário informando sobre a proposta nova política de segurança; dicas de segurança; conheça sua comunidade, que apresentaria os líderes das associações e representantes das agências públicas; reclamações da comunidade e as decisões tomadas pelos agentes públicos para resolver a demanda; colaboradores do PCS, para apresentar os policias que trabalhavam no posto, já que muitos não moravam na própria quadra que o posto atuava; e uma seção divertimento com jogos para atrair diversos públicos com um quadro dois jogos para que o cidadão entretivesse e levasse consigo o informativo.

Depois de vários dias trabalhando na edição e de o sargento conversar com os comerciantes para propor o financiamento da impressão, a edição número um ficou pronta e apresentada ao comando da unidade local pelo gestor para dar continuidade. Aqui estava o problema do sistema híbrido de policiamento (tradicional/comunitário). As concepções de policiamento eram de policiamento comunitário, o informativo era somente o primeiro passo estabelecido pelo gestor do posto para a "aproximação" com a comunidade local para depois compartilhar os processos de decisão e de ações com a sociedade civil organizada.

O gestor voltou da reunião com o comandante local sem querer falar mais sobre o informativo. Mais de um mês de trabalho ficou no silêncio do sargento. O então Major que comandava a unidade da região administrativa, subordinado diretamente ao então Tenente Coronel Comandante do Policiamento Regional que estava Subordinado ao Coronel chefe do Departamento Operacional não queria problemas, não queria assumir possíveis riscos que estas ações poderiam repercutir e, se desse errado, poderia macular o policiamento de uma área sob sua responsabilidade. A recompensa de ser promovido a Tenente-coronel não poderia ser ameaçada em assumir riscos para promover uma ação de uma política que não havia consenso entre os oficiais superiores da PMDF. 
A autonomia necessária para o policial comunitário apresentada nos fluxos de soluções e debatida virtualmente nos cursos não era um capital que o gestor possuía por causa da longa cadeia hierárquica que concentrava responsabilidade e poder de decisão em apenas alguns oficiais. A percepção desenhada pela SENASP/MJ, ratificada pela SSP/DF e pelo CPCDH/PMDF não conseguia concretizar nas práticas de alguns gestores de PCS`s e dos policiais comunitários.

O gerenciamento dos policiais comunitários, tendo dois "comandantes", tornouse uma anomalia no sistema militar. Os policiais militares que trabalhavam nos PCS seguiam determinações e orientações do $\mathrm{CPCDH}$ e estavam subordinados administrativamente ao comando da unidade policial local. Quem tem o poder de transferência, de deferir requerimentos de férias e abonos, de mudar escalas e mudar a vida cotidiana do policial é o comandante da unidade local, a quem o policial que trabalha no posto comunitário estava vinculado administrativamente. Assim, as recomendações seguidas seriam as determinações locais. Como disse um sargento com aproximadamente 28 (vinte e oito) anos de serviço policial militar, "não iria comprar briga com o comandante para ficar inventando coisas".

Desta forma, a ação do gestor dos PCS's e dos policiais comunitários eram enfraquecidas, não sendo possível realizar com plenitude, mesmo que fosse uma interpretação do que seria policiamento comunitário. Conviver com o modo de policiamento tradicional, que ainda tinha como comprovar seus resultados, pois os dados construídos privilegiavam categorias do ethos guerreiro, minavam gradativamente as ações alinhadas à nova política comunitária e desestimulavam a mudança das práticas de outros policiais porque o desgaste com a administração poderia afetar a vida pessoal.

Como consequência, houve a diminuição da possibilidade de mudança do ethos e do habitus do campo de controle social. Economicamente falando, mudar a tradição era um custo muito alto. As mudanças em uma instituição total dificilmente se fazem por decretos e portarias. Gerações diferentes que tiveram gradações de socialização de policiamento e de militarismo diferentes, todavia, compartilhando do mesmo habitus, grupos táticos repressivos da criminalidade reconhecidos como sendo o policial ideal corroboraram para inicialmente serem um obstáculo à implementação do Policiamento Comunitário no Distrito Federal. Assim como Giddens (1996) descreve as características do conceito, o conservadorismo destes policiais militares é guiado pela autoridade informada e legitimada por diversos símbolos, pela lealdade ao grupo porque sua filiação 
está muito mais ligada em tradição do que em associação racional, e esta tradição está relacionada ao conhecimento tácito que é essencialmente prático.

O habitus dos campos está atrelado a uma leitura de como associar a atividade policial ao militarismo, assim, a rígida hierarquia e concentração do poder decisório está associada às ações policiais, ficando ao policial de rua a missão de executar o que foi determinado, caçar criminosos. O processo de socialização profissional reifica este ethos cotidianamente. Isso é que foi aprendido e retransmitido durante as várias gerações da polícia e nos vários grupos operacionais. A desconstrução gera um gasto de desassociar suas ações, apreender outras, sem que haja a certeza da nova prática e sem saber qual será sua posição no novo sistema. Gera um clima de insegurança e uma perda dos capitais simbólicos conquistados até então, não é só uma desconstrução das práticas diárias, mas uma desconstrução individual do agente de segurança dentro do próprio campo, que teria de desconsiderar o que tinha aprendido como solução para a contenção e controle da criminalidade, mas também conquistar outros capitais para se colocar no campo de controle e ser reconhecido com um bom policial.

\subsection{CONSEG}

A relação entre o controle da criminalidade e a ampliação da rede e dos atores envolvidos, com a participação da sociedade civil organizada, sinalizando com uma possível mudança na participação da população local para uma participação mais ativa na esfera do prevenção e no controle do delito começou a ser modelada com o Decreto 24.101 de 2003 do Governo do Distrito Federal, que estabelecia a criação dos Conselhos Comunitária de Segurança (CONSEG). Segundo o decreto, eram competências dos Conselhos Comunitários de Segurança

I - constituir canal privilegiado pelo qual a Secretaria de Estado de Segurança Pública e Defesa Social - SSPDS obterá subsídios da sociedade para otimizar a atuação dos órgãos de segurança do Distrito Federal, em beneficio do cidadão e da comunidade;

II - congregar as lideranças comunitárias afins, conjuntamente com as autoridades locais, no sentido de planejar ações integradas de segurança que resultem na melhoria da qualidade de vida da comunidade e na valorização dos integrantes do sistema de segurança pública; 
III - auxiliar as autoridades na definição e execução de ações prioritárias de segurança;

IV - mobilizar a comunidade, visando à solução de problemas que possam trazer implicações à segurança pública;

V - estimular o desenvolvimento de valores cívicos e comunitários;

VI - sugerir programas motivacionais, visando maior produtividade dos agentes de segurança da área, reforçando sua auto-estima e contribuindo para reduzir os índices de criminalidade;

VII - incentivar a integração e a interação entre a comunidade, as lideranças comunitárias afins e as instituições de segurança pública;

VIII - promover palestras, conferências, fóruns de debates, campanhas educativas e outros empreendimentos culturais que orientem a comunidade na percepção de riscos à sua segurança;

IX - realizar estudos e pesquisas com o fim de proporcionar o aumento da segurança na comunidade e maior eficiência dos órgãos integrantes da segurança pública, inclusive mediante convênios ou parcerias com instituições públicas e privadas;

$\mathrm{X}$ - encaminhar às autoridades competentes, por intermédio da Gerência dos Conselhos de Segurança Comunitária, propostas ou subsídios para elaboração legislativa em prol da segurança da comunidade. (DISTRITO FEDERAL, 2003)

O Conseg tornava-se um espaço que a comunidade local poderia pesquisar, problematizar os dados, sugerir às autoridades competentes da Região Administrativa ou do Distrito Federal práticas ou ações para melhorar a sensação de segurança e diminuir índices de criminalidade. A comunicação agora tinha traços formais e legitimados pela legislação vigente e era diretamente com os representantes das agências da Secretaria de Segurança Pública.

O decreto determinava que houvesse sempre um Representante do Poder Executivo local, um representante da Polícia Civil, um da Polícia Militar, um do Bombeiro Militar, e um do Departamento de Trânsito, todos teriam que ter poder de decisão para que as demandas apresentadas fossem resolvidas na própria reunião do Conselho.

Já no final de 2003 foi iniciada a implementação do Programa de Segurança Comunitária no Distrito Federal com o intuito de modificar as relações entre os cidadãos e os agentes públicos de segurança (SSPDF, 2003). Tratava-se de uma política de segurança pública que tinha como fundamento a filosofia de polícia comunitária, todavia, estendida a todas instituições de segurança pública. O Decreto 24.316 de 2003 instituía a política de segurança pública Segurança Comunitária para

I - contribuir para a resolução dos problemas sociais com reflexos na área de segurança pública a curto, médio e longo prazo;

II - envolver a comunidade na gestão da política de segurança pública e defesa social; 


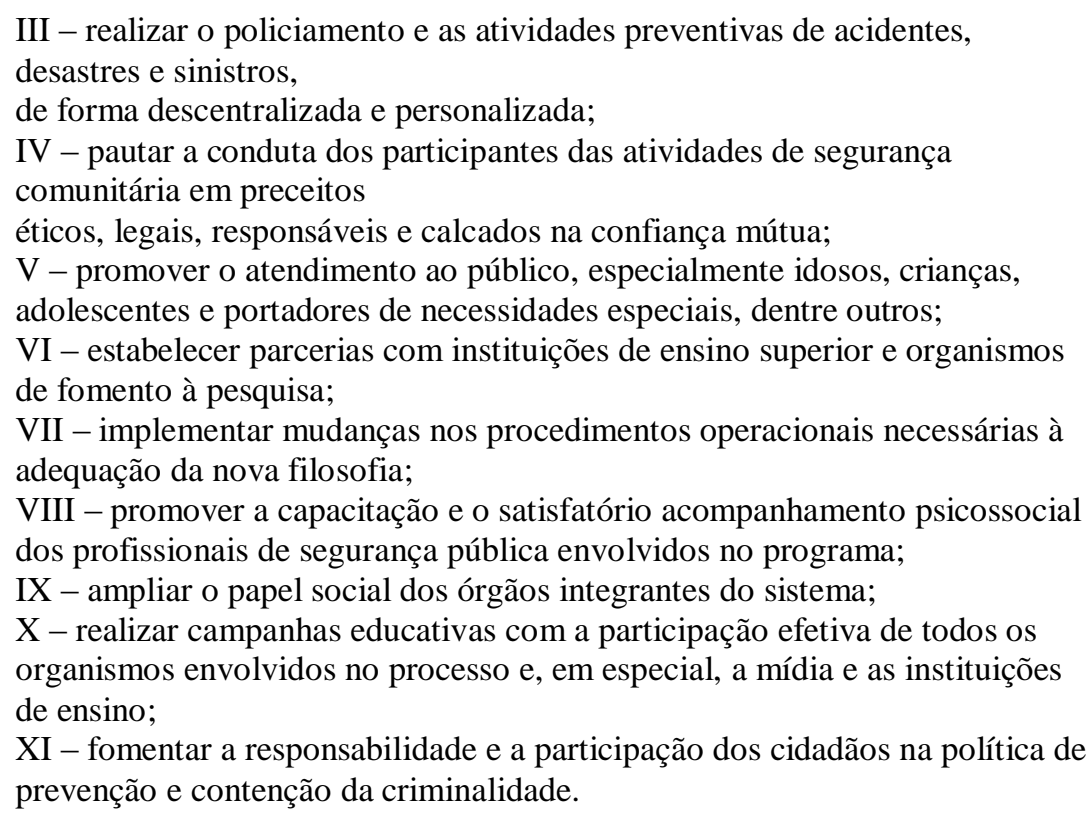

Todavia, esses decretos não apresentaram efeitos práticos na atuação dos policiais militares que patrulhavam as ruas ou planejavam ações cotidianas. A integração entre as agências de segurança determinada nos decretos não modificou o sistema de informação das polícias e do Detran e não modificou os procedimentos de atuação na prevenção ou repressão local. Como consequência, estes decretos simplesmente não ficaram registrados na memória dos policiais militares ao serem questionados durante esta pesquisa. Tanto oficiais quanto praças não tinham conhecimento que já havia orientações para mudança de procedimento e que adotassem ações de policiamento comunitário.

Entretanto, o decreto foi o marco legal que orientava as agências de segurança a voltarem suas práticas para a doutrina de policiamento comunitário. E no mesmo marco legal ratificava a importância da participação dos cidadãos na política de prevenção e controle da criminalidade e criava a estrutura administrativa dos Conselhos de Segurança do Distrito Federal com o objetivo de identificar e mobilizar os segmentos das comunidades para promoverem, junto com os órgãos do Sistema de Segurança, programas de prevenção à violência, à criminalidade e ao fomento da cultura da paz local. Já no decreto 26.291 de 19 de outubro de 2005 houve a modificação da nomenclatura de alguns Conselhos e reestruturou as funções dos seus membros.

Com o novo decreto, também foram criados os Conselhos de Segurança Especiais, compreendendo os CONSEGs ESPECIAIS/Rural, Conselhos Comunitários Especiais de Segurança Escolar - CONSEGs ESPECIAIS/Escolar, Conselho Comunitário Especial de 
Segurança da Universidade de Brasília - CONSEG ESPECIAL/UnB, Conselho Comunitário Especial de Segurança dos Rodoviários - CONSEG ESPECIAL/Rodoviários, Conselho Comunitário Especial de Segurança dos Taxistas CONSEG ESPECIAL/Taxistas, Conselho Comunitário Especial de Segurança dos Postos de Combustível - CONSEG ESPECIAL/Postos de Combustível, Conselho Comunitário Especial de Segurança da Indústria Gráfica - CONSEG ESPECIAL/INDÚSTRIA GRÁFICA, Conselho Comunitário Especial do Comércio Atacadista - CONSEG ESPECIAL/COMÉRCIO ATACADISTA e Conselho Comunitário Especial do Transporte Alternativo - CONSEG ESPECIAL/TRANSPORTE ALTERNATIVO.

Todavia, os que tinham maior abrangência eram os CONSEG/RA, Conselhos Comunitários de Segurança das Regiões Administrativas do Distrito Federal. Cada Região Administrativa teria, no mínimo, um Conselho Comunitário e, em algumas cidades com maior extensão e com produção agrícola, há também CONSEG/Rural.

Quanto à estrutura estabelecida pelo decreto, ela ficou composta pelo Presidente, Vice-Presidente, Diretor Comunitário, Primeiro Secretário e Segundo Secretário. A legislação determinava que os membros candidatos aos cargos da diretoria do Conselho Comunitário de Segurança fossem eleitos entre os membros colaboradores previamente cadastrados pela Secretaria de Segurança Pública e teriam mandato de quatro anos.

Poderiam se cadastrar como membro colaborador os representantes de entidades comunitárias com atuação efetiva na área funcional e territorial do Conselho. Por entidade comunitária entendia-se, por força do referido Decreto, como sendo grupos assistenciais, religiosos, sindicais, profissionais, estudantis, artísticos, culturais e outros agrupamentos sociais prestadores de serviços relevantes à coletividade, de qualquer natureza, com objetivos lícitos e sem fins econômicos, formalmente constituídos ou não. Também poderiam se cadastrar como membros colaboradores dos Conselhos os líderes comunitários que detinham representatividade de grupos sociais com interesses comuns, sem expressão econômica, mediante aprovação prévia de setor competente da Secretaria de Estado de Segurança Pública.

As funções dos Diretores dos Conselhos de Segurança Comunitários não eram remuneradas, e seriam consideradas, por força do decreto, como serviço voluntário prestado à comunidade local.

A nova estrutura dos Conselhos também contava com a participação das agências do Sistema de Segurança, tornando-os Membros Governamentais Efetivos dos 
CONSEGs, outorgando poder de decisão ao Administrador Regional da respectiva Região Administrativa; ao Delegado-chefe de Polícia Civil da respectiva Região Administrativa; ao Comandante da unidade da Polícia Militar com responsabilidade da área; ao Comandante da unidade do Corpo de Bombeiro Militar; e ao representante do Departamento de Trânsito da Região Administrativa. A presença de todos estes membros era obrigatória no CONSEG/RA, já no CONSEG/Rural poderia ser de um representante das agências.

Com o início do novo Governo em 2007, poucas coisas foram modificadas em relação aos conselhos inicialmente, sendo modificado no decorrer do mandato.

Segundo o Subsecretário de Programas Comunitários (SUPROC) do então Governo, quando assumiu a subsecretaria havia somente 16 (dezesseis) CONSEG's constituído e em funcionamento e, em sua gestão, este número passou a ser de 35 (trinta e cinco) em todo o Distrito Federal. Ainda segundo o Subsecretário, o CONSEG tonaria um dos pilares, ao lado dos Postos Comunitários, que auxiliariam na implementação da Política do Policiamento Comunitário do Governador Arruda.

Para tanto, foi dada a oportunidade para que os membros dos conselhos de segurança pudessem realizar os curso de promotor de Policiamento Comunitário, em convênio com a SENASP/MJ, juntamente com os policiais militares e outros agentes de segurança pública. Mesmo sendo a participação no Conselho e no Curso voluntária, houve uma participação maciça dos membros eleitos da maioria dos Conselhos.

Todavia, não havia condições para o trabalho dos membros do Conseg. Não havia sede, salas e materiais para desenvolverem atividades próprias de cada membro. Convites para as reuniões, os ofícios ou qualquer documento eram digitados em computadores particulares e impressos na Administração Regional da cidade.

Uma vez por mês os membros de cada Conseg se reuniam em suas Regiões Administrativas. Como não havia salas ou edificações própria para o conselho, e como os PCS não comportavam a quantidade de pessoas, diferentemente do projeto inicial, o presidente do Conseg solicitava aos representantes de diversas agências estatais espaço para ceder durante uma tarde. Salas de aula, sala de posto de saúde, quartel da Polícia Militar eram algumas opções que o Presidente do Conseg tinha para coordenar os trabalhos do Conselho e as reuniões. Desta forma, não havia um calendário com os prováveis locais das reuniões, a única certeza que se tinha era que teria a reunião, o local se saberia em tempo oportuno. Em 2008 houve o convênio 633052/2008 entre o Governo 
do Distrito Federal e a SENASP/MJ para estabelecer Territórios da Paz no Distrito Federal, entre os objetivos a serem alcançados estavam a estruturação das sedes para os Conseg das Regiões Administrativas.

A diversidade de local da reunião, que poderia ser uma forma de fazer conhecer as atividades do Conselho Comunitário local e a doutrina de Policiamento Comunitário, era percebida como um empecilho às atividades pela maioria dos membros dos Conselhos de Segurança pesquisados. A busca por um local que desse referência ao trabalho era uma solicitação da maioria dos conselheiros.

A participação da comunidade também era limitada aos ritos estabelecidos pela SUPROC e conduzidos pelo presidente do conselho. Eram realizados dois registros da reunião: um pelo secretário do Conseg e outro pelo representante da SUPROC que fazia uma ata para apresentar na SUPROC.

Durante a pesquisa, foi possível verificar que há nas Regiões Administrativas vários grupos que trabalham voluntariamente e captam as demandas sociais, geralmente por serviços públicos estatais, e tentam suprir tal vácuo estatal com diferentes níveis de mobilização da comunidade local ou prestando o serviço demandado. Para tanto, utilizam-se recursos próprios, doações privadas ou por convênio entre Secretarias de Estado e a instituição proponente. Assim, há associações que prestam serviços de creche para crianças até a idade escolar, há as que desenvolvem atividades sócio-educativa para jovens em horário alternados às aulas, há ainda aquelas que desenvolvem oficinas profissionalizantes para adultos e idosos. O grau de mobilização e confiança destes grupos, aliado com o grau potencial de legitimidade que os serviços dos órgãos do Sistema de Segurança detém, seriam um instrumento para a implantação e manutenção da Segurança Comunitária.

Todavia, percebemos durante a pesquisa que este recurso de mobilização disposto nas comunidades é subutilizado quando nos referimos à política de Polícia Comunitária, principalmente no pilar que o Subsecretário chamou de base, o Conselho de Segurança Comunitária (CONSEG). Foi percebido que, nos CONSEG's, há um afastamento entre os representantes do Sistema de Segurança Pública com os líderes comunitários, com as organizações representativas e com as Organizações Não-governamentais que captam recursos para trabalharem na sociedade. Assim, o espaço que as lideranças comunitárias encontram para apresentar suas solicitações por serviço público é a reunião do Conselho Comunitário de Segurança da cidade. 
Nas reuniões observadas, havia a presença de caráter obrigatório dos representantes do Sistema de Segurança Pública (PMDF, PCDF, CBMDF, DETRAN/DF), e os representantes convidados da Gerência Regional de Ensino, da Gerência Regional de Saúde, do Conselho Tutelar, da Companhia de Saneamento Ambiental do Distrito Federal (CAESB, empresa estatal responsável pelo abastecimento de água potável e tratamento de esgoto no DF), da Companhia Elétrica de Brasília (CEB), do Departamento de Estrada e Rodagem (DER) e do representante do Governo do Distrito Federal (GDF), do Administrador Regional de Brazlândia. São raros os momentos em que a população de Brazlândia conseguiria encontrar tantos representantes do poder público com poder de decisão em um mesmo lugar dispostos ou coagidos a resolverem problemas.

Apesar da limitada divulgação dos encontros mensais de Segurança Comunitária pela falta de recursos do Conselho de Segurança da cidade, em uma das reuniões do Conselho de Segurança Comunitária havia representantes de diversas denominações religiosas, representantes dos comerciantes locais, representantes de várias organizações não-governamentais, entre outras pessoas que não estavam associadas a grupos, mas também percebiam que ali estava o espaço de diálogo entre cidadão e representante do Estado.

O local de uma das reuniões observadas foi em uma escola infantil, o que poderia facilitar a divulgação com os alunos e responsáveis. Entretanto, nenhum dos grupos que trabalham voluntariamente na região havia sido informado, nem os líderes comunitários. O que diminuiu a representatividade da comunidade e a diversidade de demanda e soluções.

Nesta reunião, o presidente do Conseg informou que a população tinha o direito de solicitar serviços aos representantes do GDF porque a iluminação pública pode ser uma questão de segurança pública, assim como a manutenção de uma pista ou a sinalização de uma faixa de pedestre pode salvar uma vida. Várias solicitações foram realizadas. Havia a solicitação para a sinalização de uma faixa de pedestre em frente ao colégio de um determinado bairro da cidade; solicitaram um abrigo em um ponto de ônibus; a mãe de três crianças solicitou informação sobre o seu cadastro em um programa de assistência do Governo Federal e do Governo do Distrito Federal; solicitaram policiamento próximo à escola infantil; outra mãe de aluno questionou à diretora da escola infantil sobre sua atitude quanto à violência na escola, que pudemos interpretar que seria 
bulling; a diretora solicitou aos representantes do GDF um elevador para a escola para os portadores de necessidades especiais; moradores cobraram atividades de lazer na quadra poliesportiva próxima à escola; uma senhora reclamou do acesso limitado que o Administrador disponibiliza na Administração Regional; outra senhora reclamou que não há bueiros nas ruas; entre outras reclamações.

Em outra reunião, pode-se verificar que a política de Segurança adotada com reuniões em diversos lugares, inclusive escolas públicas, não há a receptividade esperada. O presidente do Conseg da Região Administrativa informou que o diretor de uma escola dificultou a divulgação e a realização da reunião na escola em que administrava. Assim como nas outras reuniões, houve várias solicitações da população a qual destacamos algumas: iluminação da rodovia limítrofe da área da Cidade; falta de sinalização entre dois Bairros; reclamações dos comerciantes sobre a atuação dos policiais militares quando fiscalizavam e autuavam condutores que estacionavam seus veículos em áreas proibidas; reclamações sobre possíveis prostíbulos perto de determinada via.

O representante da SUPROC anotava todas as solicitações, assim como cada representante de agência. Assim que lhes era concedida a palavra cada representa da agência estatal demandada apresentava a resposta. Em um determinado momento da reunião houve um pequeno debate acerca das causas da criminalidade, mas como instrumento de defesa das ações policiais e para justificar números de variação da criminalidade. Nesse sentido, diante da sensação de insegurança que os cidadãos declaravam, o representante da unidade policial militar local iniciou a discussão sobre a responsabilidade das instituiçõoes judiciais.

Pôde-se verificar que as ações do Campo de Controle do Delito (órgãos policiais administrativos e judiciários, sistema judiciário, sistema penal e sistema de reinserção social) são percebidas pela população local como descontínuas e desarticuladas. Como resposta, tanto o representante da Polícia Civil quanto o representante da Polícia Militar apresentaram justificativas do alto índice de criminalidade semelhantes aos roteiros típicos que criam os suspeitos oficiais (COELHO, 2005); às teorias dos lugares desviantes que informa que a causa de vários crimes está relacionada às características urbanísticas dos lugares, às condições sócio-econômicas e étnicas dos moradores; e que a sensação de insegurança está relacionada a midiatização de alguns crimes, mas a sensação não corresponde à realidade dos fatos, já que houve diminuição do índice de criminalidade quando comparado com o mesmo período do ano passado. Todavia, os representantes das 
agências policiais apresentaram somente os dados que foram registrados, e a sensação de insegurança poderia estar relacionada ao tráfico de entorpecentes e aos roubos não registrados naquela localidade.

Em outra reunião, o presidente do Conseg da cidade iniciou uma discussão acerca da responsabilidade criminal atribuída aos jovens menores de 18 anos. Para o representante do Conselho, a condição "menor idade" propicia o aumento da criminalidade pela sensação de injustiça que as medidas sócio-educativas propiciam aos "menores". Todavia, o representante do Conselho Tutelar da Criança e do Adolescente foi contrário aos argumentos apresentados pelo presidente do Conseg de culpar somente os jovens pelas conduta desviante.

Apesar do debate que se aproximava de um debate acadêmico, a discussão terminou no momento da culpabilidade. Não houve mais nenhuma discussão sobre as causas e os efeitos da criminalidade na cidade durante a reunião. Os representantes das agências do Sistema de Segurança Pública se posicionaram apresentando dados sobre taxas de crimes e atuação policial, denunciando a percepção que tinham de inoperância do sistema judicial e concluíram relacionando impunidade com a legislação nacional vigente.

As reuniões do Conseg se tornaram o espaço privilegiado que a população tem para solicitar serviços aos representantes do Estado que, pela presença dos demais representantes do governo e da presença de líderes comunitários, tentam solucionar as demandas da população pelo maior controle social que a reunião propiciou.

Neste sentido, as reuniões do Conseg não alcançam o seu fim: distribuir os "poderes" da produção de objetivos, planos de trabalho e metas para a maior sensação de segurança pública; fomentar a maior participação da comunidade local em assuntos pertinentes aos interesses públicos e especificamente à segurança; e aumentar a integração entre os órgãos de segurança e entre estes e a comunidade.

As técnicas de resolução de problemas descritas nos manuais de policiamento comunitário dos cursos ministrados presencialmente ou a distância no curso de Multiplicar e Promotor de Polícia Comunitária disponibilizados para os agentes de segurança e para os membros dos conselhos não foram utilizadas. Não se utilizava o método de Identificar o problema, analisar as possíveis alternativas, planejar as ações, implementar as providências e avaliar as providencias implementadas. 
Assim, as reuniões do Conseg se tornaram um balcão de interpelação e reivindicações de serviços públicos. Determinadas ações policiais eram percebidas como ilegítimas por determinados setores da comunidade. A causa desta percepção é a falta de comunicação e planejamento das prioridades da atuação policial entre a polícia e a comunidade como um todo.

Os serviços obtidos eram individualizados, assim como a solução. A não elaboração compartilhada com a população de metas de diminuição da criminalidade pelos representantes das polícias eram frutos de ações contrárias à política de segurança e ao decreto, e os conflitos ali surgidos (de cidadão demandando serviço contra responsável pela oferta dos serviços) faziam com que os grupos tivessem postura de apresentar justificativas às acusações de má prestação de serviço de segurança pública. As relações ali presentes não formavam um conflito que apresentassem alternativas aos problemas percebidos como individuais, mas relações de afastamento recíproco. Denominamos este tipo de interação social como interações desconstituintes de laços comunitários, pois não permitem que seja criado um espaço de atração entre os membros e de sentimento de pertencimento. O conflito gerado no Conseg não propicia uma ligação entre seus membros e não constrói identidade de grupo. O que não acontece com outros espaços destinados à possíveis conflitos, como, por exemplo, da comunidade acadêmica que tem interações constituintes de laços comunitários.

Para Simmel ( 2005) o conflito é uma das principais interações entre os indivíduos em uma sociedade, é parte. Os conflitos, nesta perspectiva, interpretamos como sendo um dos elementos constituinte das formas de interação, pois pode unificar. É sociante do grupo. Para tanto, não há indiferença.

As relações sociais dos conselhos de segurança são conflituosas e demarcam classe de prestadores de serviço e comunidade, a unidade constituída pelo conselho é de separação de grupos bem delimitados, em que há de um lado os grupos que tentam justificar a não prestação do serviço e do outro grupo que demandam serviço.

Esta relação de conflitos gerados durante as reuniões dos Conseg e as demonstrações de forças fazem com que quanto menor o número de pessoas na reunião seja melhor para os representantes da agência. Ao mesmo tempo que o conflito gerou uma unidade, os Conseg's, também desconstitui os laços comunitários, são conflitos que mantem o Conseg como uma unidade associativa, todavia, por elementos que não se identificam como em comunidade. 


\section{4 - POLÍTICAS PÚBLICAS DE SEGURANÇA: COMO AS POLÍTICAS PERMANECEM}

Após a implementação dos pilares da política de segurança pública, a janela de oportunidade de implementação começa a fechar e os fluxos começam a desalinhar. A força que fomentaram a formação da agenda de segurança pública e o início da implementação agem de forma diferente nas regiões administrativas. Agora o papel dos destinatários da política de segurança, os policiais militares e os cidadãos, desempenham papel importantíssimo na manutenção da política.

A convergência do fluxo começa a desalinhar quando os atores que agiam no fluxo político preocupam-se com outras questões e o cenário político modifica-se. $\mathrm{O}$ ano de 2009 e 2010 foi atípico para o Distrito Federal. No final do ano de 2009 a Polícia Federal inicia a Operação Caixa de Pandora que envolvia diversos empresários da capital federal com deputados distritais, com o vice-governador e o Governador. O escândalo político ficou conhecido como Mensalão do DEM porque os políticos denunciados recebiam mensalmente uma quantia em espécie das empresas contratadas para realizar obras na cidade. $\mathrm{O}$ acordo ilegal permitia que as mesmas empresas continuassem sendo contratada desde que pagassem a mensalidade aos políticos, esquema arquitetado, segundo a Polícia Federal inicialmente, e ratificado pelo Poder Judiciário, pelo Governador do Distrito Federal, filiado ao Democratas. A denominação de Mensalão coloca uma referência ao Mensalão do Partido dos Trabalhadores, em 2005, que ocupou os debates políticos e a atenção na mídia local e nacional. A força política que estava presente no Governador e mudou o Secretário de Segurança e determinou e à Polícia Militar que fossem indicados policiais militares para frequentar os cursos de promotor e de multiplicador de Polícia Comunitária sai do cenário que compunha o fluxo político.

Em 2010 o Governador Arruda é o primeiro governador a ser preso no Brasil. Em seu lugar assume o Vice-Governador que renunciou posteriormente por ter sido denunciado na mesma operação. O Distrito Federal passa a ser governado interinamente pelo presidente da Câmara Legislativa Deputado Wilson Lima que renuncia após dois meses. O Deputado Rogério Rosso assume para conduzir o governo interinamente até o término do ano.

Não havia mais força para manter o fluxo político e os indicadores do fluxo de problemas não podiam ainda demonstrar se o início da política poderia modificar a 
sensação de segurança de maneira significativa; e se, mesmo não mudando o habitus dos policiais militares ou suas convicções, que as estratégias da Polícia Comunitária são mais eficientes do que a práticas tradicionais; ou se houve impacto no controle da criminalidade. Pelo contrário, no início da implementação algumas taxas de crimes violentos aumentaram, conforme a tabela abaixo.

Tabela 4 -Crimes violentos registrados no Distrito Federal de 2005 a 2013

\begin{tabular}{|l|c|c|c|c|c|c|c|c|c|}
\hline & 2005 & 2006 & 2007 & 2008 & 2009 & 2010 & 2011 & 2012 & 2013 \\
\hline $\begin{array}{l}\text { Homicídio } \\
\text { Doloso }\end{array}$ & 515 & 539 & 567 & 654 & 690 & 657 & 704 & 819 & 720 \\
\hline Latrocínio & 52 & 56 & 49 & 60 & 51 & 139 & 44 & 47 & 27 \\
\hline $\begin{array}{l}\text { Lesão Corporal } \\
\text { seguida de morte }\end{array}$ & 9 & 6 & 9 & 10 & 4 & 58 & 13 & - & - \\
\hline $\begin{array}{l}\text { Roubo de } \\
\text { veículo }\end{array}$ & 1523 & 1.596 & 1574 & 2.136 & 2756 & 2854 & 2769 & 4120 & 4143 \\
\hline
\end{tabular}

Fonte: FBSP, 2008, 2009, 2010, 2011, 2012, 2013 e 2014

Os números absolutos dos registros dos crimes continuaram altos e, na maioria dos casos, aumentaram após a implementação da Política de Segurança. Se não era possível medir a eficiência e a eficácia pelo curto tempo da implementação da tentativa de mudança do habitus pelos cursos, portarias e decretos, era possível verificar que as estratégias não conseguiram diminuir os números. Todavia, a sensação de segurança começou a mudar para alguns moradores próximos aos PCS's porque eles tinham a sensação que poderiam contar com o apoio da Polícia Militar.

As ações do Governo do Distrito Federal e do Governo Federal continuaram para tentar consolidar a doutrina de Policiamento Comunitário e em 2008, independente do cenário político de conflitos na SSP/DF e na PMDF causadas pelas resistências internas, os burocratas continuaram executando os convênios e contratos já firmados. O viés teórico-doutrinário que a Suproc da SSP/DF desejava que os policiais assimilassem era o mesmo que a Senasp/MJ do Governo Federal apresentava ao oferecerem cursos presenciais e à distância. Todavia, os diversos conflitos desassociativos dentro da própria 
Secretaria de Segurança Pública nos primeiros anos de governo dificultaram a continuidade das ações que estavam voltadas para a mudança das práticas policiais (desde o planejamento até a ação policial) e reestruturação da PMDF que descentralizasse as decisões e desse autonomia aos policiais que estivessem desenvolvendo o policiamento comunitário.

Todavia, o sistema de recompensa para os oficiais superiores estava incerto pelo cenário político impreciso. Os preparativos para as eleições de 2010, pelas condições ímpares do cenário político do Distrito Federal, não reuniram condições para que no ano de 2009 eles tivessem um papel tão ativo para saber quais grupos políticos lhe prestigiariam. Assim, os políticos voltaram suas forças para estabelecer alianças e os fluxos de problemas (saúde, segurança, transporte, educação, entre outros) ficaram com menos força no processo de formar agenda novamente. Assim, o comportamento dos oficiais foi de esperar o plano político se definir. O vácuo do conflito entre policiamento tradicional e policiamento comunitário permitiu que ações locais fossem desenvolvidas em prol de um e de outro. O hibridismo do policiamento ganhou relevo nas ações dos policiais militares, agora a flexibilidade oculta tornou-se mais perceptível, dando origem ao Policiamento Comunitário Real. As análises que se seguem partem deste contexto fora dos muros dos quarteis, mas que influenciaram a legitimidade de algumas ações de policiais que se apropriaram do Policiamento Comunitário como forma de trabalhar no cotidiano.

Portanto, as análises que se seguem partem deste contexto fora dos muros dos quarteis, mas que influenciaram a legitimidade de algumas ações de policiais que se apropriaram do Policiamento Comunitário como forma de trabalhar no cotidiano.

\subsection{Policiamento Comunitário Real}

Da mesma forma que tentei desenvolver o Jornal Informativo no posto que trabalhava para iniciar o que entendia como Policiamento Comunitário, outros policiais desenvolveram atividades após realizarem os cursos de promotor e multiplicador. Entretanto, os entrevistados que trabalharam na Suproc e que trabalharam na Senasp não relataram se tinham previsto que o processo de apropriação do conceito poderia 
diversificar o entendimento e a sua aplicabilidade no cotidiano policial. Algumas destas ações foram forçosamente rotuladas como Policiamento Comunitário para tentar dar um rótulo moderno a uma prática tradicional, que também já foi relatado em outras experiências no mundo (Bayley,2006 ).

Como foi salientado, a interiorização e apropriação do que seja policiamento comunitário foi diferenciada nos grupos, tanto nos policiais militares quanto nos diversos grupos da sociedade brasilense, assim como são diversas as interações entre estes grupos e os policiais militares. Denominamos policiamento comunitário real as apropriações práticas policiais sobre policiamento comunitário ao interagir com a sociedade na tentativa de consolidar a política pública nas relações diárias. O não estabelecimento de metas, a falta de um roteiro de procedimentos e a falta de instrumentos de avaliação da política de segurança pública permitiram que houvessem gradações de apropriação do que fosse policiamento comunitário.

Diante desta diversidade de apropriações e releituras dos conceitos, de grupos e gerações nas unidades policiais militares, de estratificações sociais que relacionam com as diversas tipologias, que inter-relacionam entre cidadão e policial militar, houve gradações de apropriações e implementações da política pública de instalação dos postos comunitários, mudança das ações policiais e da participação da sociedade civil nos assuntos da segurança pública. Mesmo com as diversos tipos de resistências de oficiais e praças, a doutrina alterou de alguma forma as práticas laborais cotidianas.

Destacamos, inicialmente, que entre os limites categóricos de implementada a política e não-implementada, há diversas formas e apropriações. Já os limites categóricos propriamente ditos da política de segurança pública no tripé estabelecido, há o insucesso totalmente em alguns casos e, em alguns casos, a consolidação de um dos pilares projetados no processo de implementação da política conseguiu manter os outros dois pilares.

Após a fase inicial de preparação e instalação dos primeiros postos, houve uma processo de adaptação pelos policiais e por parte da população. A oferta por cursos por parte da Senasp na plataforma EaD e possibilitou a aproximação da doutrina com os policiais mais resistentes. A adaptação administrativa para que muitos policiais fizessem os cursos. Não era mais necessário que os policiais fossem encaminhados pelos comandantes de unidades, faziam as inscrições diretamente na plataforma. 
O trabalho nos postos policiais também foi alterado. A responsabilidade de exercer o policiamento ficou prioritariamente para o gestor (comandante do PCS) e o sub gestor. Os outros policiais não tinham mais a obrigação de preencher relatórios de "produtividade", atenderiam ocorrências e patrulhariam e, quando fosse possível, realizariam as diversas visitas para subsidiar os relatórios. Estes procedimentos burocráticos também faziam com que os policiais de rua tentassem se afastar das práticas de policiamento comunitário. Todavia, como em alguns PCS`s só havia uma viatura por posto, os gestores e os subgestores também diminuíram a produção de dados preenchendo relatórios, e atualmente é raro o PCS que manteve a rotina de preenchimento de relatórios.

Esta nova configuração da relação entre os policiais militares e os cidadãos, com a possibilidade de ser mediado pela doutrina de policiamento comunitários e possivelmente nos postos comunitários, possibilitou as variações de "abertura ou aceitação" dando um grau de liberdade aos grupos policiais se seguiriam com o policiamento tradicional ou tentariam policiar comunitariamente. Comecemos então pela apresentação do menor grau de recepção à política pública até o maior grau.

Em relação às práticas policiais diárias, esta apropriação diferenciada se dá pela reflexividade da vida social (Giddens, 1991), isto é, pelo constante exame das práticas sociais e reformulações à luz desta mesma prática (Giddens, 1991:45); e pela disposição que os policiais militares tinham em compartilhar a construção dos poderes que está intimamente ligada à construção dos poderes (Foucault, 1985 e 1987) Permitir que outros façam sugestões e acatá-las é compartilhar o espaço de produção de saber que também está compartilhando poderes. Outro pressuposto é que os poderes não estão somente nas agências de controle, mas também estão presentes nas micro-relações, ou seja, os poderes são capilares. Dessa forma, os policiais também, ao (re)produzirem poderes, estão (re)produzindo saberes e ao compartilharem este espaço com a comunidade local também estão compartilhando estes poderes e estes saberes.

\subsubsection{O Abandono: Quando os Policiais Não Querem e a População Não Quer}

Como destacado anteriormente, os fluxos que permitiram a construção da agenda necessitavam estar alinhados para que a manutenção da política se mantivesse. Todavia, com as crises políticas envolvendo o governador e as constantes mudanças do chefe do 
poder executivo com a prisão do Governador Arruda e do seu Vice, Paulo Otávio, sendo sucedido por outros dois governadores no mesmo ano, tendo o Distrito Federal quatro governadores no mesmo ano, resultou em um baixo apoio político ao grupos que desenvolviam a implementação e manutenção da política pública, grupos contrários e a favor do policiamento tradicional (praças e oficiais) ganham força dentro da PMDF.

O governo Agnelo Queiroz do Partido dos Trabalhadores assume o governo em 2010 e em pouco tempo inicia a implementação do Programa Ação pela Vida como política para a segurança pública. O programa consistia em estabelecer metas de apreensões de arma, droga, redução de índices de criminalidade, entre outros fatores que estavam vinculados ao policiamento tradicional. Todavia, a imagem do policiamento comunitário estava vinculado ao policiamento para o cidadão, policiamento voltado aos direitos humanos e, entre outros motivos, não há a possibilidade de abandonar por completo uma plataforma do Governo Federal que tem o mesmo partido e legenda política.

Outros fatos políticos como, por exemplo, reivindicações dos policiais militares e melhorias de trabalho prejudicaram os serviços de atendimento à população, aumentando os índices de criminalidade e a sensação de insegurança. O movimento chamado de Operação Tartaruga retardava o tempo de atendimento das ocorrência e os policiais militares primavam apenas para o atendimento de ocorrências graves, as unidade de policiamento especializado diminuíram quase que totalmente a produtividade policial militar.

Segundo o ex-Subsecretário da SUPROC, houve um abandono velado da política pelos dirigentes da PMDF ao deixar o policiamento comunitário como segundo plano. Todavia, não tinham força para retirar totalmente a doutrina. Como justificativa, para tal abandono velado, diziam que a prática policial da PMDF já é uma prática de policiamento comunitário, o que precisava era mudar a produção dos policiais.

Se o fluxo político permitiu parte dos policiais abandonarem veladamente a politica pública, a escassez dos recursos necessários para a manutenção demonstrou a falta de investimento e planejamento para o desenvolvimento do Policiamento comunitário na capital. A falta de uma política contínua de formação de novos policiais fez com que houvesse uma diminuição do efetivo policial, reduzindo a quantidade de policiais aptos para a atividade policial militar e para manter o sistema híbrido de policiamento tradicional e policiamento comunitário. 
Nesta perspectiva, quanto ao pilar da política de instalar os postos policiais como referência de serviço de segurança pública e como técnica de estabelecer uma aproximação entre a Polícia Militar do Distrito Federal e a sociedade policiada, houve uma estratégia que não estava no projeto inicial realizado durante o processo de transição de governo, não estava no segundo projeto de Policiamento Comunitário ao assumir o governo e nos planos da equipe da Comissão de Implantação do Policiamento Comunitário: a modificação da quantidade de módulos nos mesmo lugares já instalados.

Como o quantitativo de policiais militares não aumentou, não havia mais possibilidade de instalar novos PCS e, mesmo alterando escalas e diminuindo a quantidade de policiais por equipe, não havia o mínimo necessário para a instalação e para manter um posto policial para realizar patrulhamento, mesmo que fosse o policiamento tradicional.

Como havia sido comprado todo o quantitativo de trezentos postos policiais pelo Gerente indicado pelo Governo Arruda, e como a instalação dos postos ficou sob a responsabilidade do Comando da Polícia Militar, os outros governos não influenciaram mais na instalação do postos. A solução encontrada foi reagrupar os postos policiais. $\mathrm{O}$ segundo projeto, da equipe de implantação, entendia que cada local de postos policiais deveria ter um módulo simples ou, no máximo, dois postos. Todavia, a solução encontrada pelas outras gestões foi instalar mais postos.

A decisão de onde instalar e quantos instalar por local foi tomada em reunião com gestores dos postos policiais

[...] Primeiro teve o [número do posto policial], aí como o governo tinha 300 postos pra montar, o governo anterior, passou o governo e não tinha montado os 300, tinha montado 100 e poucos, e acho que não foi de interesse da Polícia continuar montando esses postos porque não tinha efetivo, aí o que eles fizeram? Naquelas reuniões que a gente fazia, com o Coronel Oficial $5^{29}$ na época, ele explicou que não tinha efetivo pra montar mais posto e se tinha alguma Unidade que poderia colocar um

\footnotetext{
${ }^{29}$ Oficial responsável pelo comando da $\mathrm{CPCDH}$, responsável pelo gerência da implementação da doutrina de policiamento comunitário.
} 
posto duplo num local onde a área era grande, aí nós solicitamos que duplicasse porque com as quadras novas a área ficou bastante extensa, aí outros postos também eles duplicaram porque não tinha efetivo pra estes postos todos. (Sargento Policial Militar, com quase trinta anos de serviço policial, gestor de PCS)

Esta instalação não seguiu critérios de proporcionalidade de policial por área, criminalidade local ou qualquer outro critério estabelecido nos primeiros projetos. A intenção era somente instalar os módulos comprados. Em alguns postos policiais foram instalados mais de um, de forma improvisada, disponibilizando cadeiras e mesas para que fossem usadas para reuniões. A estética, como permitir que os módulos de PCS fizessem parte da paisagem urbano defendido no projeto arquitetônico pela equipe de engenheiros e arquitetos que trabalhou no segundo projeto ficou em segundo plano, as instalações dos módulos seguiram o critério de espaço territorial próximo ao posto.

Fotografia 2 - PCS 001, após a instalação do segundo módulo, seis anos após a inauguração

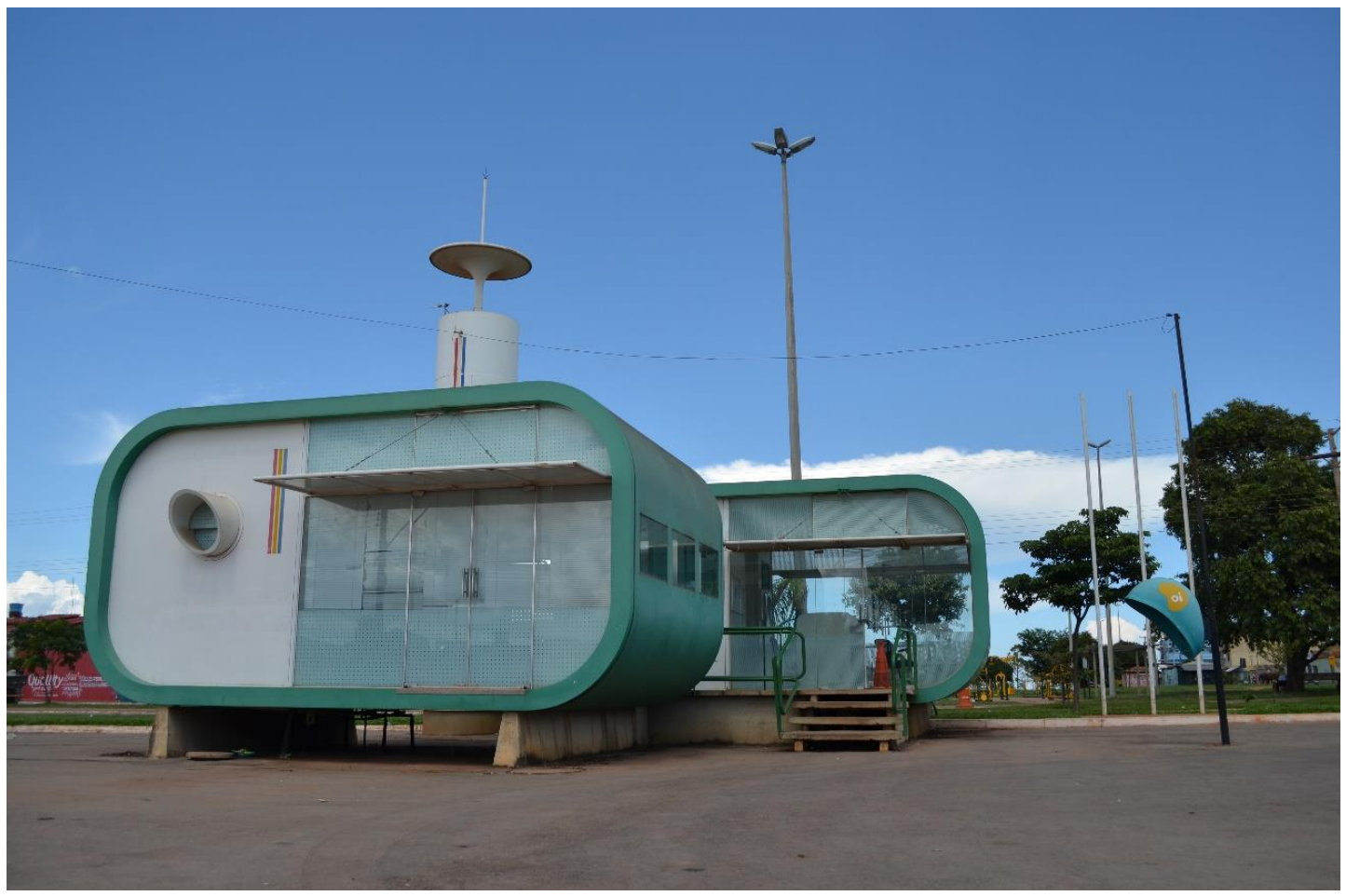

Fonte: Arquivos do pesquisador, 2014 
A imagem registrada na fotografia 2 é do mesmo espaço da fotografia 1 que retratava o primeiro posto. Todavia, se na primeira fotografia havia um automóvel e duas motocicletas, dois policiais no interior do posto e mais um policial na torre de observação, esta simboliza o que aconteceu com alguns posto. As portas estavam trancadas, não havia viaturas e policiais para atendimento.

Em outros espaços, houve a instalação de mais dois módulos em alguns lugares, como demonstra a fotografia 3 abaixo, formando uma rede de módulos de PCS, em que só se justificaria pelo sargento pelo grande espaço atrás do primeiro módulo.

Fotografia 3 PCS 115. Cidade Estrutural.

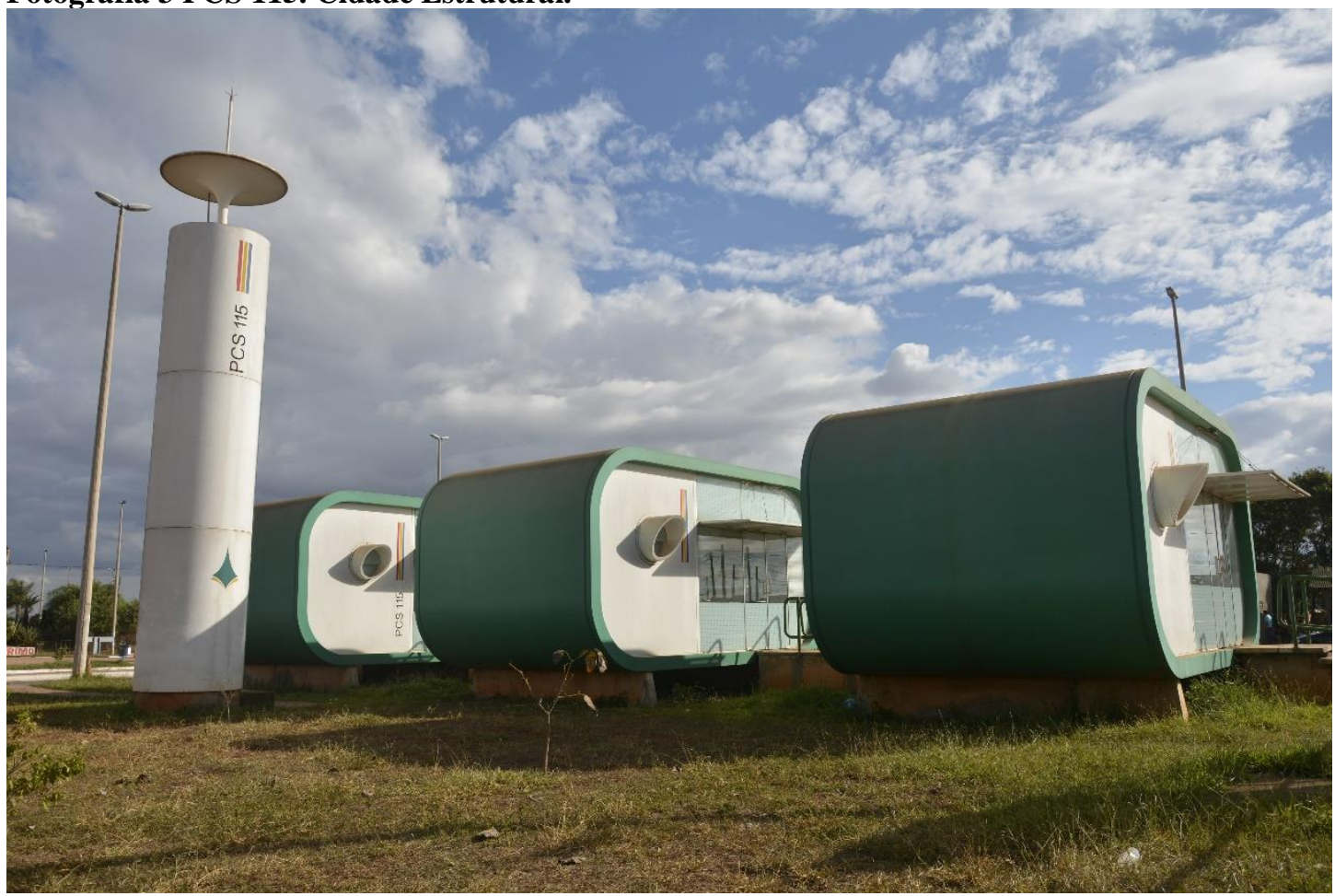

Fonte: Arquivos do Pesquisador, 2014

O acúmulo de módulos no mesmo lugar não garantia maior sensação de segurança. Em algumas unidades policiais escalar policiais nos PCSs passou a ser uma questão de aritmética, pois, com o pouco efetivo policial, a única possibilidade que havia era de manter o posto aberto, com dois ou até mesmo um policial à noite. Não havia mais a preferência de manter somente policiais que tivessem o curso promotor ou multiplicador de policiamento comunitário para trabalhar no posto. Também não havia mais a possibilidade de manter sempre a mesma equipe para que houvesse um maior entrosamento e continuidade dos trabalhos iniciados de envolvimento e aproximação com 
a comunidade. A prioridade passou a ser a segurança das instalações do PCS para não permitir que pichassem ou depredassem os módulos, pois, até então, seria uma desonra para os policiais militares não garantir a segurança e integridade da própria sede.

Muitos PCS passaram a ser somente posto policial. Assim como os outros postos que já existiam na cidade antes da política ser implementada. O que seria improvável em outros momentos, passou a ser uma constante em alguns postos, ou seja, a inoperância do posto. Muitos postos policiais são fechados em determinados horários para que os policiais façam o patrulhamento na cidade ou para atender ocorrências.

Apesar de a maioria das viaturas trazerem inscrições de policiamento comunitário, de ter veículos grandes para serem bases móveis, o tipo de policiamento empregado é o mesmo do policiamento tradicional. As viaturas exclusivas para o policiamento comunitário agora atendem ao sistema híbrido e quando necessário são remanejadas para o patrulhamento ordinário, contrariando as primeiras determinações do comandante do $\mathrm{CPCDH}$ da viatura de policiamento comunitário atender ocorrências informada via rádio da Central da PMDF.

A falta de policiais militares também provocou a imobilidade operacional dos policiais em alguns postos policiais. A referência de segurança proporcionada pelo posto perde também sua eficácia e eficiência. Vários policiais entrevistados relataram que foram solicitados para atender ocorrências e não podiam sair para não deixar o posto policial sozinho, mesmo com uma viatura policial no posto. Como as condutas policiais são regradas por rígidos códigos militares e há uma baixa regulamentação da atividade policial, um ato de abandono de posto pode ser considerado como crime militar com consequências na esfera pessoal. O receio dos policiais era que, ao atender a ocorrência, fizessem algo com o posto.

O pilar simbólico da política tornou-se um problema para o outro governo. Pressões de setores da mídia local começam noticiar a falta de atendimento de ocorrências pela imobilidade policial. Diante da pressão, os policiais são autorizados a deixarem o posto para deslocamento de patrulhamento e atendimento de ocorrência. Muitos policiais relataram em entrevista que se sentiram livres por poder patrulhar novamente e sair do Kinder-Ovo, nome que os policiais militares deram aos PCS. Kinder-ovo era produto destinado ao público infantil que o formato do recipiente envolvido por chocolate e guardava uma surpresa (pequenos brinquedos) era semelhante ao formato do PCS e os policiais se sentiram um brinquedo na mãos dos governantes. 
A população que estava assistida próximo aos postos deixa de ter o policiamento ou a referência que dispunha. Mesmo que como policiamento tradicional ou apenas um policial ainda havia uma referência de segurança pública. Os policiais militares agora são cobrados pela população para manter o posto policial e patrulhar a cidade. Todavia, este não é um clamor por policiamento comunitário, mas por policiamento com resultado imediato, não necessariamente com o envolvimento da comunidade na identificação e resolução dos problemas.

Alguns postos passaram a ser fechados com correntes. Durante o trabalho de campo, em visitas aos postos policiais de várias regiões administrativas, não foi possível precisar quantos postos estavam em funcionamento e quantos estavam permanentemente fechados porque as repostas aos questionamentos era que aquele posto funcionava, todavia, o efetivo estava realizando o patrulhamento ou estavam em ocorrência. Mas alguns postos policiais ficaram fechados por várias horas. Ao entrevistar os moradores próximos dos postos pesquisados, estes relatavam que os policiais patrulhavam e só abriam os postos para utilizarem o banheiro ou descansarem por alguns minutos, mas logo saiam novamente.

O temor de vários policiais se concretizou assim que alguns postos foram transformados apenas em posto base de descanso, sendo "abandonado" por alguns instantes. Após a nova prática de prevalecer o policiamento tradicional em detrimento ao policiamento comunitário, o que se temia aconteceu e a depredação nos postos policiais iniciou de forma não orquestrada, em diferentes pontos do Distrito Federal. Durante o trabalho de campo, foi observado diversos tipos de depredações em Santa Maria, Guará, Ceilândia, Estrutural, Riacho Fundo, Recanto das Emas, entre outras regiões administrativas. Pichações, destruições das portas, furtos de objetos no interior dos postos fechados e incêndios são alguns fatos que foram observados durante a pesquisa de campo.

A frágil estrutura dos postos com paredes laterais de vidro, composto por material potencialmente inflamável não resistiu às iniciativas dos incendiários. O revestimento externo de fibra de vidro com isolamento termo-acústico incendeia-se rapidamente. 


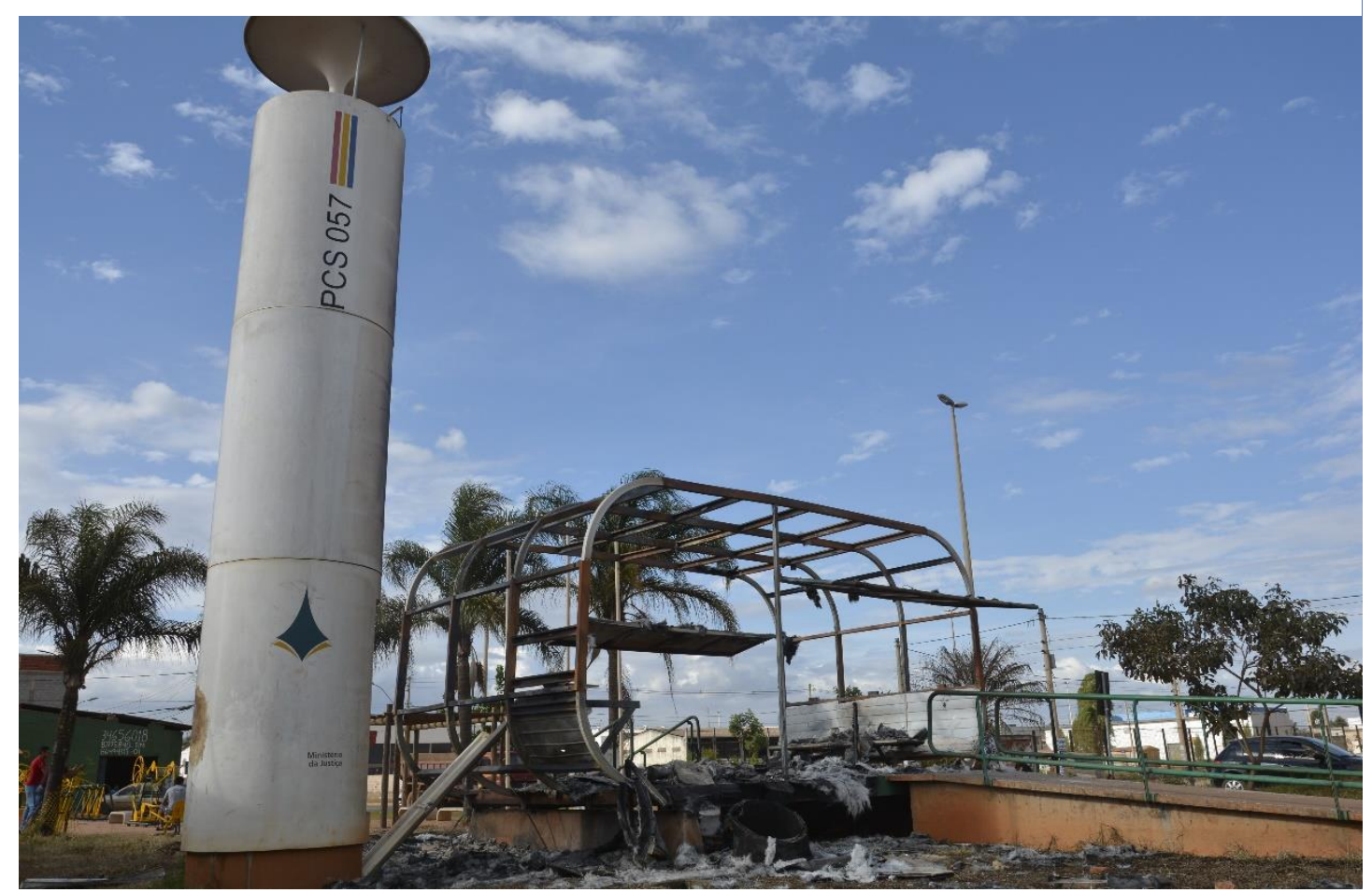

Fonte: Arquivos do pesquisador, 2014

Conforme demonstrado na figura, a combustão deste material é, geralmente, total. Dez por cento aproximadamente dos postos instalados foram queimados em diversas cidades do Distrito Federal. Outros foram depredados. Foram incendiados postos nas cidades de Santa Maria, Itapoã, Paranoá, Guará I e Guará II, Sobradinho, Estrutural e São Sebastião. Os ataques tiveram motivações diferentes. Um dos ataques foi um sinal de retaliação pela ação policial em determinada data que resultou em algumas prisões. Um dos envolvidos ordenou que um jovem colocasse fogo em um PCS. Um ataque pessoal que demonstra uma das faces da implantação da política pública de Estado.

Para um dos Sargentos Gestor de PCS, a queima dos postos policiais, que é uma questão de polícia, o fez entender o valor da visita solidária às vítimas. Em sua fala, a sensação de injustiça era o sentimento do gestor em não saber do andamento da investigação ou da prisão dos incendiários de outros postos. O que seria uma afronta à instituição, para outros policiais entrevistados, a queima dos Kinder Ovo estava apenas apressando um processo de retirar o policiamento imóvel. Para estes policiais, é como se fosse "um favor" aos policiais. Durante uma entrevista a este pesquisador, o excomandante geral da PMDF, Coronel Anderson, informou que as depredações ocorridas 
nos postos policiais simbolizava que a PMDF era uma instituição democrática, que não havia medo por parte da população em relação às ações policiais, que era um bom sinal pois não aconteceria se houvesse uma instituição que seus membros não respeitassem os direitos humanos e os direitos coletivos.

As várias formas de desvinculo com a política pública, desde a nomeação dos postos por Kinder Ovo pelos policiais militares, as diversas formas de depredação (das pichações, passando pela quebra dos vidros, até o extremo incêndio do módulo policial), até o silêncio por parte da sociedade civil em não se manifestar pela reinstalação dos postos em substituição aos postos incendiados representa a recusa ao modelo proposto. Além do prejuízo material, o abandono por ambos os envolvidos reduz a possibilidade dos vínculos comunitários, o que reforça o ethos guerreiro e o habitus policial militar.

\subsubsection{Grupos policiais tentam convencer a população a querer}

Todavia, esta percepção da política foi realizada por parte dos grupos que a política foi direcionada, isto é, por parte dos policiais militares e por parte da sociedade. Concomitantemente ao abandono das práticas de policiamento comunitário e dos PCS, há ainda grupos que tentam manter o que se percebeu como polícia comunitária. As mudanças de comandos gerais e de Secretários de Segurança não permitiu que houvesse uma marca própria que deveria ser empregada como política, a fragmentação das ações foi constante e os comandos de unidades policiais nas regiões administrativas, assim como os gestores, tiveram maior liberdade para empreender ações para diminuir a criminalidade e manter vínculos mais próximos com a população local.

As ações dos comandantes de unidades alinhadas à política pública eram diversas e não planejadas, da mesma forma que os ataques aos postos não havia um planejamento orquestrado, estas ações também foram pontuais e sem um padrão estabelecido.

Em algumas cidades os comandantes de unidades permitiram que os gestores de PCS desenvolvessem algumas atividades de policiamento comunitário com o objetivo de aumentar a colaboração entre a população e a Polícia Militar. Foram constatadas várias ações iniciadas por policiais militares que obtiveram bons resultados com relação ao objetivo. 
Na cidade de Brazlândia, onde foi instalado o primeiro posto policial, houve várias ações após a mudança de comando da unidade. Com o novo comando da unidade, com um Major "mais policial do que militar", o sargento teve maior liberdade para tentar implementar o que entendia como ações de policiamento comunitário. O novo comando via como uma possibilidade de se projetar e ganhar reconhecimento pelo Comando Geral, tanto que pensou em televisionar o começo da ação de policiamento comunitário.

Tratava-se do programa de segurança que disponibilizava números de telefones móveis que estavam em cada viatura, além dos telefones do quartel e do PCS. O intuito era diminuir o tempo de resposta às demandas da população. O cidadão que necessitasse do atendimento policial não precisaria mais ligar para o número telefônico de emergência 190 e esperar que a Central de atendimento acionasse a viatura mais próxima. Os telefones móveis foram doações de comerciantes locais à Polícia Militar. Foram produzidos adesivos para as viaturas com o objetivo de informar o número de telefone. Como cada viatura patrulhava uma área pré-determinada, a equipe de trabalho sempre teria o mesmo telefone de atendimento. Vários adesivos com ímãs para serem colocados em geladeiras foram produzidos para serem distribuídos à população para divulgação do programa da unidade policial local. A ideia do programa foi do gestor dos postos. Todavia, como quem é responsável pelo quartel é o Major, comandante da unidade, as ações foram então apropriadas pelo oficial como sendo um programa de comando. A ação típica de policiamento tradicional foi rotulada e informada à população local como sendo policiamento comunitária, o que gerou maior receptividade na população e aceitação das outras práticas que vieram no Conselho Comunitário de Segurança.

Em outras unidades policiais foram desenvolvidas ações com o objetivo de desvincular a imagem de uma polícia militar truculenta e que agregasse a imagem de uma polícia cidadã. Podemos perceber que a maioria das ações eram voltadas para crianças e jovens, pois assim indiretamente alcançava os adultos responsáveis também. O gestor de um dos postos de Santa Maria conseguiu desenvolver em cinco anos de serviço no posto várias atividades. Atividades para idosos, crianças, entre outros grupos que, com a ação para diminuir a distância entre cidadão e policiais militares proporcionou uma dos objetivos do policiamento comunitário, legitimidade de outras ações e proximidade com a população.

Esta proximidade entre policiais e comunidade local também foi percebida em outros posto 
A gente conhece a realidade $-[. .$.$] Teve posto que foi um sucesso$ absoluto, na Asa Sul por exemplo a gente tinha umas senhorinhas que elas levavam vasinhos de flores colocavam lá no posto, levava lanche pros policiais, então, assim, houve apropriação... a comunidade se apropriou daquele posto. Então foi algo que foi, assim, força centrífuga, a comunidade se apropriou do posto. (Oficial 1, participante do grupo de trabalho do primeiro projeto)

Como destaca o Oficial 1, então tenente em 2007, que auxiliou na idealização do primeiro projeto, viu que, mesmo o policiais oferecendo resistência, há locais em que a comunidade força a integração pelo simples fato de haver um posto policial próximo e a força de fora para dentro (força centrífuga) tem como consequência uma maior integração entre a comunidade e a polícia.

Já na Região Administrativa Taguatinga um gestor cadastrou todos os moradores em sua região. Segundo o Oficial 4, Coronel da PMDF, foi uma ação individual no Distrito Federal. Para o sargento gestor do posto era imprescindível conhecer todos os moradores da região para iniciar o trabalho de policiamento comunitário. Este policial havia conseguido um grau de vínculo com a população local comunitário próximo daqueles descritos que são realizados no Japão. Tanto que, certo dia, um cano havia quebrado na residência que estava na área sob a responsabilidade dos policiais do PCS deste sargento e não havia ninguém na casa. A rua toda já estava tomada pela água e nenhum vizinho tinha o contato telefônico do morador. O socorro veio do sargento que conhecia o morador e, a partir dos cadastros e visitas realizadas, conseguiu manter contato telefônico com o morador que estava no trabalho e pôde avisá-lo do acidente.

Apesar de não serem ações especificamente de policiamento comunitário, mas ações de melhoria da imagem institucional, são estas ações que mantêm um dos tripés de base da política de segurança ativo, o envolvimento ativo de um dos grupos com interesse em desenvolver as ações próprias de policiamento comunitário. Estes gestores, de forma individualizada, formam um pequeno efetivo que não compartilham com o ethos guerreiro como solução para a diminuição da criminalidade. 
A energia dispendida por estes agentes públicos de segurança, sem recursos materiais e sem apoio institucionalizados como programas da PMDF, assumindo todos os possíveis ônus das ações planejadas localmente em caso de insucesso, pois pode ser responsabilizado administrativamente, é um sinal de disposição em continuar o processo da política de segurança.

Essas ações foram denominadas de resultantes da força centrípeta do policiamento comunitário pelo Oficial 2, em que ações foram individuais de agentes de segurança, a partir do centro do PCS, irradia suas ações com o propósito de criar vínculos comunitários com a população local. Interessante esta leitura pois permite compreender como que a política poderia ter sido planejada além dos materiais necessários, de estratégias para alcançar os vínculos comunitários diante da diversidade social que os PCS são instalados.

Houve também as ações em que os protagonistas foram os policiais militares, o que o Oficial 1 chamou de força Centrífuga, em que a integração entre comunidade local e policiais militares teve origem nas ações dos policiais militares, de dentro para fora do posto.

O reconhecimento dessas ações e integração se deu também por aqueles que eram referência para os brasileiros como policiamento comunitário, os policiais japoneses que, por convênio com a Senasp/MJ auxiliou as ações de fomento da implementação do policiamento comunitário no Brasil. Em visita a Brasília, os policiais japoneses consultores realizaram uma observação de como estava sendo realizado o policiamento comunitário no Distrito Federal. O oficial 1 testemunhou uma destas visitas, segundo o oficial policial militar, um cabo da PMDF trabalhava em um posto em Brasília

[ ...]. Esse Cabo ficava na 416, 14, não, era 416 ou 216. Eu fui ciceronear uma equipe do Japão que vieram aqui conversar com a gente né? "Eu sei que vocês fizeram o curso lá em São Paulo e a gente quer saber o feedback”, aí nós fizemos uma palestra pra eles, tal, contamos a experiência em São Paulo e como foi o retorno pra Brasília e aí a gente saiu, eu, o Tenente Aguiar e o Capitão Lourenço, aí a gente foi nesse posto do Cabo Roberto e quando chegamos no posto e mostramos as pessoas da comunidade e tal, eu me lembro que o japonês falou "Isso é o 
KOBAN! Eu saí do Japão e estou vendo o KOBAN aqui no Brasil"

$[\ldots]$

É. Depois da palestra, depois que ele viu in loco e tal, tinha político no meio porque o Secretário também estava, ele, o japonês, fez questão de conversar com o policial da ponta, aí chamou o tradutor, tinha um tradutor, que era da (sigla), que trabalhava aqui, aí chamou esse japonês que veio pra fazer a conferência e chamou o Cabo Roberto e o pessoal da comunidade.

Ele ficou muito entusiasmado dizendo que aquilo ali era o KOBAN.

O modelo Koban, reconhecido como referência no Brasil, estava "presente" no Distrito Federal, esta satisfação em ver o policiamento funcionando, segundo o Capitão, estava presente no projeto inicial, caracterizado como um projeto técnico e não político pelo então Major, Oficial 2,

\section{$[\ldots]$}

Uma estratégia que fazia parte da concepção original dos postos, por exemplo, você tem o posto do Cabo Roberto e naquela área tem em torno de 16 prédios e cerca de 30 policiais trabalhando no posto - então você dividia os policiais e cada policial daquele, do posto, seria responsável por um prédio, eu vi isso in loco em São Paulo, na Praça (nome da praça), então, assim, eu sou o policial do posto numa escala 12/60 e no dia que cair meu serviço eu tenho que visitar meu prédio", então pelo menos uma ou duas vezes por semana aquele prédio vai receber a visita de um policial - então somos nós dois aqui na viatura, então a gente visita o meu prédio e depois visita o seu prédio, ou vice-versa; aí você vai conversar com o porteiro ou com o síndico, tem um questionário pra responder "Conversei com fulano de tal, tal horas..." e colocar as observações positivas e negativas, tal, e tudo era insumo pro 
planejamento, aquilo tudo vai ser processado no futuro. Então o policial da ponta, independente do nível de graduação, você tem um nível de responsabilidade que vai crescendo, você é responsável por aquele prédio e o gestor é responsável pela área inteira - e aí você levantou você mesmo... como você se identifica com aquele prédio você dá um toque "Estou saindo do serviço e de manhã o problema lá é tal; de noite é isso - dá pra passar lá e dar uma olhada (Oficial 1)

Todavia, eram ações individuais promovidas sem estabelecer as redes que o Campos do controle do delito já tem constituída. As redes são locais, apenas com a comunidade, sendo que poderiam ser estabelecidas com a Suproc, com outras agências da SSP/DF e com agências de outras Secretarias de Estado. É o que desejava os primeiros que projetaram a política pública.

[...] Tipo assim, beleza, eu identifico um problema lá na Santa Maria, o problema lá na Santa Maria é a ociosidade dos jovens porque não tinha opções de lazer e tudo mais, sobretudo no período da noite de $23 \mathrm{~h}$ até as duas horas da manhã, os jovens ficam ociosos, fazem uso de droga etc. Então "Beleza, vamos montar um grupo de esporte à noite em Santa Maria?" "Vamos montar? A gente tem ambiente político pra isso? A gente tem suporte administrativo da administração [regional], tem efetivo apoio da unidade pra colocar policial lá?" “Tem”. Beleza. Juntamos o Conselho de Segurança e vamos botar um esporte à noite em Santa Maria, então, o Esporte à Meia-Noite ele é uma ação da Polícia Comunitária pra dar uma resposta, mas ela não é a Polícia Comunitária. A Polícia Comunitária foi essa parceria, esse diálogo que ocorreu antes pra definição de qual resposta a gente daria pra esse fenômeno específico [...] 
Assim, as ações do Programas da Suproc (Esporte à Meia Noite, Picasso Não Pichava, entre outros) seriam soluções para problemas específicos que, após serem identificados, seriam disponibilizados aos gestores para desenvolverem em sua localidade. Todavia, esses gestores que estavam desenvolvendo suas atividades reconhecidas como policiamento comunitária até mesmo pelo consultor da Senasp/MJ desenvolvem suas atividades com as redes constituídas informalmente, no raio de ação de seus PCS’s e intermediado pela PMDF.

A iniciativa foi uma iniciativa individual, foi cada gestor que essa iniciativa de desenvolver esse trabalho; fazia parte, como eu estava falando, do projeto original, baseada na filosofia de Polícia Comunitária, agregar valor ao Posto Comunitário de Segurança e não só aquela ideia de posto policial de "Eu sei que ali tem policiamento", mas você ter também ali projetos sociais e atividades que envolvesse a comunidade. Não. Essa iniciativa foram os próprios gestores de determinados postos que falaram "Vamos fazer alguma coisa", tiveram algumas experiências que foram muito bem sucedidas, infelizmente, com a queda do Arruda os governos que vieram depois dele não apostaram na filosofia de Polícia Comunitária e hoje não sei como está mais, mas poderia ter sido um sucesso muito grande. (NORMANDO, exSubsecretario da SUPROC)

A promoção dessas ações também apresentam duas características importantes para a manutenção ou fomento dos vínculos comunitários:

a) A construção da imagem de pertencimento à comunidade, que é um membro do grupo, diminuindo as possíveis relações que as construções das identidades policial e militar podem ter sobre as diversas estratificações sociais (tanto da maioria quanto da minorias estratificada), já que o convite para usufruir os serviços nas ações é feito a todos da localidade policiada; ser um semelhante, do grupo, é condição essencial para que estas ações possam ter o sucesso esperado. 
b) A busca pelo reconhecimento começa a se deslocar para fora dos quarteis. Mesmo que estas ações resultem em um reconhecimento institucional da PMDF, pelo comando da unidade, da corporação ou da SUPROC, o ser reconhecido pela população como o policial da área que promoveu a ação, que ajudou a andar a cavalo, que colocou o filho na viatura para andar, que deixou entrar no helicóptero, ou que ensinou para que serve os diversos caminhões/tanques dos BOPE para as crianças reconstroi para estes policiais qual capital social é importante e, sucessivamente, pode começar a remodelar o habitus policial militar, já que diminui o ethos guerreio que pressupõe um distanciamento da comunidade. Neste contexto de policiamento de aproximação para manter vínculos comunitários com a população local, ser bom policial é o policial que mantém uma boa comunicação com a população e, fruto desta boa comunicação, há as prisões e a diminuição da criminalidade.

\subsection{Fatores Exógenos ao Campo de Controle: As Construções Fora do CONSEG}

O pano de fundo do policiamento comunitário é o (res) estabelecimento de um sentimento de comunidade entre as pessoas de uma localidade e que este (res) estabelecimento seria fomentado pelas agências de segurança pública. Assim, os laços comunitários seriam (res) estabelecidos pela sensação de insegurança local ou pela vontade comum em prevenir a criminalidade.

Para tanto, além da auto identificação com os membros componentes desta comunidade, o respeito, a solidariedade e a amizade seriam importantes para auxiliar no processo de formação de comunidades (CARDOSO, 2005). Neste contexto, as agências de segurança pública seriam um agente ativo enquanto a sociedade um ser passivo.

Entretanto, será que somente uma instituição é capaz de ser fomentadora de algo que mobiliza tantas agências e a vida cotidiana dos cidadãos? Se for possível, será que a sociedade civil aceita esta ação precursora da polícia militar, de outras instituições da segurança pública ou de qualquer instituição do Campo de Controle Social? Será que a sociedade quer constituir ou retomar este espírito de "comunidade"? Será que a sociedade do Distrito Federal quer compartilhar esta responsabilidade de ser um ente de negociação/planejador nas conflitualidades modernas? 
Se não é possível garantir o protagonismo das instituições de segurança pública nesta complexa relação de formação de comunidade e envolvimento com questões da segurança pública, foram percebidas redes sociais no Distrito Federal com a mesma concepção comunitária e com a mesma lógica da estratégia e da filosofia do policiamento comunitário. Em Ceilândia e em Brazlândia há redes sociais em que membros da PMDF também participam como uma tentativa de realizar ações de proximidade com a população local, todavia, o papel da Polícia Militar neste espaço é o mesmo dos outros participantes, de coadjuvante, sendo protagonista o coletivo da rede.

Diferentemente dos Conselhos Comunitários que são formados por Decreto e as formas de interações não possibilitam o processo de constituição de uma comunidade, as redes sociais observadas são formas de associação voluntárias e desenvolvem relações sociais que facilitam a formação de uma comunidade.

As Redes Sociais analisadas são redes que foram fomentadas por representantes da sociedade civil e por membros do Ministério Público do Distrito Federal e Territórios. Todavia, seguindo a lógica de redes, não há um único coordenador, a coordenação é transitória entre os membros que a compõe. Assim, foram analisadas duas redes: A Rede Social de Brazlândia e a Rede Social de Ceilândia.

A composição destas redes é heterogênea. Há membros representativos de associações religiosas, de organizações não-governamentais que primam pela garantia dos direitos de determinados segmentos da sociedade ou por grupos vulnerabilizados, há representantes das agências estatais, de Secretarias de Estado, entre outros. A participação é voluntária, todavia, o compromisso firmado pode comprometer o trabalho de todo o grupo, próprio da solidariedade mecânica vislumbrada por Durkheim ( 2000a).

Pela própria composição heterogênea, a discussão perpassa por diversas temáticas: saúde (do idoso, da gestante, da mulher, educação sexual, drogadição), educação (oficinas, juventude, adultos, violência no ambiente escolar, gravidez na adolescência, entre outros), segurança (assaltos em transporte público, drogadição, tráfico, violências domésticas, furtos em residências e em comércio, entre outras violências e crimes), e outras demandas sociais. Todavia, apesar de surgirem diversos debates, geralmente quem coordena a reunião apresenta a temática do mês. Assim, se a instituição que coordena oferece serviços à crianças, geralmente a maior parte das demandas apresentadas são sobre a garantia e manutenção dos direitos das crianças. 
Desta forma, há assuntos que podem envolver várias instituições no processo de formulação das soluções e no processo de resolução da problemática. Assim, questões de gravidez durante a adolescência recebeu atenção dos representantes da Gerência Regional de Ensino, da Gerência de Saúde Regional, das organizações não-governamentais, dos Centros de Assistência Social local e de cidadãos e cidadãs que se envolveram para diminuir o índice que preocupava a área de ensino pelo o afastamento precoce das jovens durante período escolar, que preocupava a área da saúde pelos riscos, pelos centro de assistência pela maioria da gravidez não planejava, e de vários outros por diferentes motivos.

Um problema social, nas Redes Sociais analisadas, é um problema da comunidade envolvida. Há a sensação de pertencimento dos membros em relação ao grupo e essa sensação de pertencimento com objetivo único (melhorar a qualidade de vida da sociedade local) reverbera nos serviços prestados na comunidade. Há um processo de identificação com o grupo.

Todos os grupos/instituições têm a possibilidade de sediar as reuniões, o que é visto como uma honra. No final do ano é decidido quem irá coordenar as 10 (dez) reuniões do próximo ano. A instituição ou grupo coordenador era responsável por confeccionar os relatórios sobre as demandas apresentadas, as possíveis soluções e os prazos dados. Também era responsável por acompanhar as ações dos entes membros que se comprometeram com determinadas ações para a solução da demanda apresentada. Assim, demandas que seriam solucionadas por um longo período seria acompanhada pelo mesmo grupo.

Desta forma, são no mínimo dez instituições que receberam as reuniões em suas sedes na cidade. No início da reunião há a leitura da ata da reunião anterior pela coordenador da última reunião. Logo após, são relatadas as informações das providências realizadas para solucionar as demandas apresentadas. Em seguida, há a apresentação da instituição que sedia a reunião, informando os objetivos das ações, serviços que são prestados, entre outras informações. Logo após é dado a palavra a todos para se apresentarem e dizer se há algumas questão na cidade que possa ser solucionada pela rede. Neste momentos há sugestões de soluções com o envolvimento voluntário dos membros do grupo. 


\subsubsection{Entrando na Rede Social}

Participar deste grupo foi um achado para eu tentar desenvolver o policiamento comunitário como havia interpretado. Eu já trabalhava na rua há dez anos, isto é, trabalhava no policiamento a pé, motorizado por automóvel e motocicleta e/ou em postos no período noturno. Trabalhar na rua se opõe, na linguagem policial militar no DF, a trabalhar no Expediente. São categorias antagônicas: ao invés de dizer que trabalha na atividade fim, realizando o policiamento, dizem que são policial de rua, operacional; ou ao invés de falar que trabalha na atividade meio, no serviço administrativo, os policiais dizem que são do expediente. Estas expressões, por serem categorias distintivas, dão capital simbólico aos policiais militares, dão projeções e reconhecimento dentro do grupo.

Todavia, depois de um convite para auxiliar no curso de Voluntários Civis ${ }^{30}$ ministrando algumas disciplinas, eu já estava decidido sair das ruas e ir para o expediente para mudar o ritmo do trabalho e descansar a mente dos conflitos vivenciados a cada turno de serviço. Escalado na Seção de Planejamento, na seção conhecida como P/3 da unidade policial, fiquei para auxiliar na produção dos dados das ocorrências registradas. Posteriormente soube que havia a Rede Social, mas quem frequentava as reuniões eram policiais da Seção de Comunicação, conhecidos como P/5. Muitos policiais que trabalham no serviço administrativo, principalmente em seções como a de comunicação, são policiais com algum problema que impede trabalhar na rua. Seja por questões de saúde ou questões administrativas (punição, solicitação de afastamento da atividade fim), assim que solucionado o impeditivo de policiar as ruas, o policial retorna às funções anteriores. Desta forma, havia uma rotatividade na frequência das reuniões já que não havia obrigatoriedade de um gestor da unidade policial participar.

Em determinado momento solicitei ser o representante da unidade nestas reuniões por afinidade com o assunto. Como estas reuniões eram percebidas como improdutivas, sempre fui autorizado, mesmo sendo soldado. Até então o nome que vinha no convite para a reunião era destinado ao comandante da unidade, até que chegou o momento que vinham dois convites, acrescendo um com meu nome. Entendi que fui reconhecido como um membro possível do grupo.

\footnotetext{
${ }^{30}$ Programa do Governo do Distrito Federal implementado em 2010 para contratar jovens acima de 18 (dezoito) anos e menor que 24 (vinte e quatro) anos para desenvolver atividades administrativas nas unidades policiais. $\mathrm{O}$ objetivo era diminuir a quantidade de policiais militares na atividade meio e aumentar a sensação de segurança nos postos policiais comunitários.
} 
O processo de acolhimento na rede foi semelhante ao que o então Tenente Oficial 1 teve na Austrália que informava os conceitos necessários para realizar um trabalho relacionado à segurança pública naquele país. Semelhante a este processo, tive um curso de contextualização e de nivelamento de conceitos. Assistente Sociais do Ministério Público do Distrito Federal e Territórios ministraram aulas sobre o que é uma rede social, objetivos, corresponsabilidades, mapeamento de redes, entre outros conceitos que auxiliaram no processo de identificação de problemas sociais e formação de resoluções.

Já a segunda reunião em que participei fui questionado por uma representante de instituição responsável pela manutenção dos direitos das crianças pela falta do serviço prestado ao solicitar uma viatura quando alguém entrava em sua sede sem autorização. A resposta, a meu ver no momento, não poderia ser diferente: Pedi desculpas pelo não atendimento da solicitação; informei que naquela região somente havia duas viaturas e que no momento as duas estavam sendo utilizadas em outras solicitações; expliquei que no serviço policial, diferente de outras áreas que dá para afirmar categoricamente qual a prioridade de atendimento, não há como deixar de atender qualquer ocorrência porque um simples desentendimento de vizinho pode resultar em morte, dependendo da dinâmica da discussão; por fim, ao informar os números telefônicos dos postos policiais, informei que iria ser solicitado que a viatura passasse em determinados horários próximo à sede, mas que deveríamos (todo o grupo da Rede Social) verificar quais seriam as outras soluções para médio e longo prazo.

$\mathrm{O}$ ato de explicar foi tão surpreendente ao grupo quanto o pedido de desculpa. Aquele momento possibilitou demonstrar que eu pertencia ao grupo sem tentativas de monopólios de assuntos. Que todos poderiam opinar sobre segurança pública e que eu aceitaria sugestões. Também permitiu que eu opinasse sobre outras temáticas que, de alguma forma, influenciariam na segurança pública local naquele momento ou em um momento próximo.

E assim foi em várias reuniões, eu já era como um "nativo" da Rede Social da cidade, participando de debates de outras temáticas e, quando solicitado, recebendo sugestões e servindo como uma ponte na Seção de Planejamento da Unidade Policial. Não tinha o poder de decisão, mas tinha a legitimidade da rede social que assinava o ofício solicitando o serviço em conjunto, com mais de 30 (trinta) assinaturas de representantes da cidade. Este era um expediente utilizado para dar "força" ao pedido às 
autoridades competentes, todos assinavam os ofícios, todos e todas representantes das instituições da cidade participantes.

Todavia, em decorrência da troca de comando da unidade, o Major Subcomandante recebeu a determinação do novo comandante de representá-lo, já que havia chegado um convite destinado ao comandante da unidade policial militar e ele precisava de algum oficial que o representasse. Para ele, seria interessante o novo comando se fazer presente e teria que ser um oficial para fazer esta representação, mesmo um soldado indo à mesma reunião.

Era mais uma reunião da Rede Social para os cidadãos de determinada região administrativa do Distrito Federal. A reunião acontecia mensalmente e todos que compareciam o faziam de forma voluntária. Além dos convidados, todos e todas que quisessem participar eram bem recebidos e teriam o mesmo poder de fala e decisão.

Desta vez eu tinha companhia, um estranho. Só que agora eu tinha mais uma missão: fazer as devidas apresentações.

Ao entrar na viatura policial para irmos, o subcomandante começou perguntando sobre do que tratava a reunião e como seria. Inicio falando que a reunião seria em uma associação filantrópica que atende idosos na cidade, informando quem faz parte e quais os assuntos das últimas reuniões: um posto do INSS na cidade, gravidez na adolescência, entre outros.

Ao iniciar o deslocamento, interrompendo minha fala, o Major expressa sua opinião sobre a reunião

Eu acho incrível o quanto que perdemos tempo com isso. O quanto que há perda dos recursos públicos. Eu, um Major de polícia, mais um sargento [ o policial que estava dirigindo a viatura] com um soldado indo para uma reunião para nada. São três policiais que poderiam estar trabalhando para evitar o crime, é muita falta de tempo

Não tive palavras para responder, estava sentado no banco de trás, atrás dele e fiquei em silêncio, o que talvez pode ter demonstrado o receio que começava sentir para os desdobramentos da reunião. 
No início da reunião, após as apresentações individuais de cada um, foi feita uma apresentação dos idosos atendidos na instituição com músicas e de poemas. A sala era arejada, mas com os mais de 60 (sessenta) presentes e no calor das $15 \mathrm{~h} 00$ próprio da região. A sala estava com todas as cadeiras em círculos ocupadas.

Quando foi permitido após as apresentações que todos falassem com sugestões, um senhor que aparentava ter aproximadamente 50 (cinquenta) anos, com linguagem simples e morador de um bairro próximo solicitou à Polícia Militar que continuasse auxiliando com o transporte das crianças até a escolinha de futebol. É comum unidades policiais militares do DF desenvolverem atividades de esporte em suas unidades ou em áreas cedidas. No caso específico, era uma escolinha de futebol que alguns policiais na hora de folga desenvolviam na cidade. Todavia, também atendiam crianças de um vilarejo próximo à cidade. Para o transporte destas crianças, havia a concessão do comando em utilizar o ônibus da unidade policial militar nos dias que não fosse utilizada para o serviço policial. O nome da escolinha era do batalhão que os policiais trabalhavam. Com a mudança de comando, a concessão foi retirada e as crianças do vilarejo, que moravam a uma distância de 05 (cinco) quilômetros da escolinha, deixaram de ser atendidas.

A escolinha de futebol, formada por policiais militares, ensinava futebol em horário contrário à educação formal, com competições entre turmas e entre outros times da cidade. Havia também o acompanhamento das notas como critério para participar dos torneios. Além dos serviços prestados, havia a confiança estabelecida que os jovens estavam sendo disciplinados e orientados para prevenir a carreira criminosa.

O senhor, morador do vilarejo, deslocou-se 05 quilômetros até a reunião por saber que lá teria um espaço de fala e com a possibilidade de ser atendidos. As reuniões são divulgadas para a sociedade civil e, cada instituição pode reverberar o convite e potencializar a rede informativa. Além dos cidadãos e cidadãs, havia representantes religiosos que desenvolvem atividades de prestação de serviço assistencial e ligados à educação, representantes de movimentos sociais, representantes de organizações nãogovernamentais que desenvolvem atividades filantrópicas de proteção aos direitos da crianças, outras de proteção ao meio ambiente, além dos representantes do Ministério Público, dos Centros de Referência de Assistência Social, Delegada Chefe da seccional da Polícia Civil, entre outras.

A resposta do Major não destoou do receio que tive dentro do carro: "Não vamos transformar esta reunião no muro das lamentações contra a polícia, estas questões o 
senhor vai até o quartel para pedir" [grifos meus]. E o silêncio se instaura na sala que em seguida quase todos olham para mim.

Solicitei o microfone e tento explicar o porque que foi retirado o transporte. Era um ônibus usado para as operações policiais. Apenas um ônibus comum pintado com a identidade visual da instituição. Mas informei que era um ônibus próprio para as ações policiais e, no momento, não era possível que crianças utilizassem aquele veículo e que o comando da unidade tentaria outras formas para continuar o transporte das crianças com parcerias como, por exemplo, com os bombeiros que também tem um ônibus. Mesmo com a tentativa de explicar e mudar o foco, a sensação geral foi que o propósito de solucionar problemas da/na sociedade de forma compartilhada tinha ficado para segundo plano para a PMDF.

A reunião continuou, com o Major inquieto e com outras participações. Quando chegou o momento da palavras para os representantes de associações e agências do Estado, foi informado que a Secretaria Nacional sobre Drogas estava oferecendo um curso Prevenção ao Uso Indevido de Drogas destinado à representantes da sociedade civil.

Também foi sugerido que montassem um grupo de voluntários da comunidade para serem mediadores de conflito. A ideia foi que se oferecesse um curso de 40 (quarenta) horas/aula aos moradores da cidade e, a partir deste grupo, houvessem espaços de mediação de conflitos. Houve a sugestão que esses espaços poderiam ser em algumas salas das igrejas e das associações. Esses espaços de mediação de conflito seriam uma instância anterior aos juizados especiais e às delegacias, todavia, um espaço informal para acolher as pessoas que, por diversos motivos, evitavam o "contato" com as instituições de controle (Polícia Militar, Polícia Civil, Ministério Público, entre outros).

Outra informação dada ao grupo por um participante representante de associação foi sobre cursos de Redução do Trabalho Infantil e sobre Exploração Sexual Infantil. Estes cursos seriam abertos à comunidade, mas seriam destinadas vagas para formar uma turma com os pertencentes à Rede Social da cidade. Como a Rede Social da cidade agrega associações que tem público diverso, mas com o mesmo objetivo de proteção de direitos individuais e coletivos, deparam-se com situações que podem orientar o atendido ou seu familiar a procurar outra instituição para resolver seus problemas.

As Redes, utilizando estas estratégias, formavam multiplicadores com grupos envolvidos na cidade e auxiliavam toda a rede social a minimizar os problemas sociais na comunidade. Mesmo que um determinado grupo tivesse como objetivo o 
reestabelecimento da saúde mental e física do drogadito, poderia encontrar durante atendimento crianças em situação de exploração ou trabalhando ilegalmente. Saber reconhecer a situação, quais os direitos que a criança tem, saber quais agências procurar para garantir os direitos e como orientar a família são algumas possibilidade que os cursos ofertados a toda rede proporcionavam à comunidade, à sociedade civil e aos operadores de direto das diversas instituições.

Como as reuniões aconteciam uma vez por mês, toda primeira terça-feira do mês, por exemplo, alguns grupos se reuniam para formar grupos de trabalho de enfrentamento de alguma situação comum aos membros. Em uma das redes, foram formados dois grupos menores, que se reuniam nas primeiras quinta-feira do mês e na quarta. Foram os grupos de enfrentamento à drogatição e de enfrentamento à violência doméstica.

Os dois grupos foram formados para solucionar questões levantadas pela própria rede. Após debates sobre causas e consequências, houve várias atividades desenvolvidas por diferentes instituições. Uma parte do grupo de enfrentamento à violência doméstica focou a prevenção nas escolas de nível médio com campanhas de conscientização como forma de prevenção. A Gerencia de Saúde disponibilizou um psicólogo para assistir a vítima e orientar o agressor. Para que os agressores frequentassem as oficinas de sensibilização sobre violência doméstica, o Ministério Público sugeria como parte da pena a frequência às sessões com os psicólogos da posto de saúde, além da pena comum para o crime. A Gerência de educação também propôs a sensibilização dos professores para a identificação de possíveis vítimas em sala de aula.

Também ficou acordado que cada componente da rede comunicaria aos demais sobre a ocorrência de violência doméstica. Assim, seria possível acionar todos os serviços disponíveis pela rede para atender à vítima, proteção a outros possíveis envolvidos, e reprimir e reintegar o agressor à sociedade novamente.

Já o grupo de trabalho referente ao uso indevido de drogas teve como ações a assistência aos dependentes químicos em um processo de sensibilização para o reconhecimento da necessidade de ajuda. Ações policiais de repressão ao tráfico integradas com ações assistências aos usuários foram as ações predominantes sugeridas em determinada localidade da cidade. O planejamento foi para curto e médio prazo.

Neste sentido, as Redes Sociais construídas em algumas cidades do Distrito Federal são um bom exemplo de como a ação comunitária, seja esta ação com objetivos para a manutenção da saúde, da educação ou da segurança, pode ter o mesmo resultado 
que o pretendido pelo policiamento comunitário. Esta lógica pode ser direcionada para qualquer ação construída com o mesmo objetivo, podendo ser pensada para outras políticas que têm como premissa o envolvimento da comunidade, como, por exemplo, agente comunitários de saúde, policiais comunitários, entre outros.

Cabe destacar que algumas ações típicas de políticas públicas de segurança (controle do uso de entorpecentes, combate ao trabalho infantil, entre outros) desenvolvidos pelas Redes poderiam ser desenvolvidas sem a participação direta das agências de controle. A mediação de conflito, a diminuição da violência doméstica, entre outras temáticas foram propostas de membros da rede e as soluções foram construídas com a participação voluntária da maioria. Somente algumas ações que era típicas de polícias de segurança pública que deveriam ser desenvolvidas por agências de controle, especificamente pela Polícia Militar. 


\section{CONSIDERAÇÕES FINAIS}

Da mesma forma que a globalização do comércio criou correntes de tendências de comportamento pelo mundo inimagináveis pela força de difusão de ideias, hoje é louvável pensar que alguns modelos de policiamento consagrados em determinadas sociedades poderiam influenciar algumas práticas locais, mesmo em culturas diferentes. Pensar o local sem pensar as redes de associações que estão envolvidos pode enevoar a análise das causas, motivações e possíveis metas. Todavia, pensar somente estas relações da Globalização - Local pode desconsiderar as ações individuais no processos estruturante das condutas coletivas.

No caso da Segurança Pública, a temática chama atenção porque os problemas podem ser os mesmos, mas nem sempre a solução necessariamente precisa ser a mesma. Se chama atenção saber quais são as variáveis que condicionam as construções de soluções diferentes para problemas iguais, também é interessante conhecer como que soluções semelhantes são escolhidas em sociedade diferentes.

O estudo da formação da agenda e da implementação do que foi chamado de policiamento comunitário no Distrito Federal a partir de 2007 possibilitou analisar este processo de difusão de soluções, as redes de soluções estabelecidas e seus instrumentos coercitivos de convencimentos, as motivações individuais encobertas por rótulos que legitimados de interesse coletivo e a influência dos indivíduos no processo de formulação, implementação e manutenção das políticas públicas.

A Polícia Militar do Distrito Federal, foco da política de segurança pública planejada em 2006, é uma instituição com grande influência na sensação de segurança. O grande quantitativo de policiais militares possibilita desenvolver várias atividades de controle das ações individuais e coletivas ao controlar o fluxo dos veículos e das pessoas, permite auxiliar no socorro em situações de urgência e emergência, mediar conflitos, agir com ações focadas no controle da criminalidade, entre outras atividades. Todavia, a grande questão é que esta importante instituição tem suas práticas para atender cada tipo de demanda, já tem suas soluções para cada problema constituídas na própria origem. Outra questão está posta então como pano de fundo das presentes análises: qual a capacidade estatal para gerenciar e mudar práticas institucionalizadas das agências de segurança pública ao implementar uma política? 
Diante de tantas variáveis para serem consideradas, é importante então destacar que o modelo de análise de Múltiplos Fluxos (Kingdon, 1984) auxiliou o processo de análise por permitir flexibilizar o olhar durante a formação da agenda de segurança pública. Foi percebido que havia soluções construídas, umas difundidas de outros países com resultados expressivos de legitimidade da ação policial. Grupos que entendem que a diminuição da criminalidade não se dá apenas com a apreensão de armas, por exemplo, que é um dos indicadores de produção policial, mas que também outros protagonistas na sociedade pode diminuir a criminalidade. Aliás, a própria construção de indicadores de produção policial já conduz para determinadas posturas das agências policiais, legitimando suas práticas ao rotulá-las como eficientes e eficazes segundo estes indicadores. Todavia, utilizar os indicadores de produtividade já conduz para determinadas políticas de segurança. O policiamento comunitário, enquanto estratégia, pode demonstrar seus resultados em médio e longo prazos, já que para a curto prazo, quando somente os policiais militares protagonizam a ação, seria com o policiamento tradicional o mais eficiente.

Entretanto, mesmo com alternativas de práticas ou de modelos de policiamento à disposição dos governantes do Distrito Federal, não houve a formação da agenda de segurança pública. Mas o fator de atração ligada à solução foi um importante dispositivo no processo de formulação dos procedimentos de implementação apoio político de algumas soluções tradicionais das associações representativas, o financiamento da política pública proposta pela Senasp, entre outras soluções e apoios criaria uma tendência que o melhor atrativo, não a melhor solução, poderia ser uma variável considerável para a aceitação da proposta para ser uma política pública.

O outro componente analisado foi a taxa de criminalidade do Distrito Federal como variável que influenciaria a formação da agenda. Foi percebido que as taxas de criminalidade são altas quando comparadas à taxa média do Brasil. Estas taxas já eram superiores à taxa nacional em 2004, todavia, mesmo assim não tiveram força para entrar em debate para que os responsáveis pela segurança pública debatesse soluções para a sua diminuição.

Já o fator político foi decisivo para a formulação política. Mas não foi um ator político específico, um político engajado ou representante de alguma categoria. Mas sim a institucionalização de um período para se pensar propostas dentro de uma lógica discursiva legitimada pela sociedade civil. A lógica anterior que conflitava o discurso da 
tradição das propostas de Roriz e a oposição petistas não teve espaço e o carisma de José Roberto Arruda juntamente com a proposta de aproximar a polícia da população, entre outras propostas, ganharam a eleição. O poder do fator político também foi importante para a origem da proposta, o número 300 foi pensado para causar um impacto eleitoral. A equipe técnica viria depois para dar a roupagem científica à política pública. Questões individuais ganhariam roupagem de interesse coletivo. A janela de oportunidade da agenda, a convergência do fluxo, de segurança pública se abriu na eleição.

A política de segurança pública pensada e depois implementada foi construída em três pilares: o posto policial como referência de aproximação entre a sociedade e os policiais militares locais; a participação da sociedade civil no processo de identificação do problema e na construção de propostas de resolução; e na mudança das práticas policiais, tornando-se um ente da comunidade que trabalha, direcionando suas ações para o compartilhamento da responsabilidade da manutenção da sensação da segurança e do controle da criminalidade e da conflitualidade.

A primeira questão a ser considerada é que tanto o projeto inicial de política de segurança de implementação do policiamento comunitário quanto a proposta de implementação da policiamento comunitário instalando 300 (trezentos) postos não tinham estabelecido metas de controle da criminalidade ou de diminuição da taxa dos crimes ou qualquer outro tipo de parâmetro para analisar e acompanhar as etapas de implementação, todavia, o projeto inicial feito durante a campanha previa $o$ financiamento, os recursos necessários, o efetivo mínimo, o calendário de instalação dos postos, o cronograma de cursos, entre outras questões. Todavia, grupos de interesses que agiam nos bastidores políticos conseguiram descartar partes do projeto inicial e a equipe de projetistas. $\mathrm{O}$ processo de formulação da agenda contou com a convergência dos fluxos de problemas, soluções e apoio político, entretanto, foram questões políticas que fomentaram e permitiram a condução da formulação da proposta, talvez porque os atores políticos sabiam que a implementação da política pública necessitaria de "pessoas chaves" nos "lugares corretos".

As redes estabelecidas pela conectividade entre as agências da segurança pública do Governo do Distrito Federal e do Governo Federal diminuíram o impacto da falta de planejamento para o financiamento e para as indicações pré-estabelecidadas na campanha. A política pública implementada era o resultado de fragmentos de vontades políticas e de grupos de interesse. Havia grupos econômicos para o desenvolvimento dos 
postos policiais, grupos que entendiam que o policiamento comunitário era a solução para médio e longo prazo para diminuir a criminalidade e legitimar as ações policiais, grupos de interesse para capitar politicamente com a instalação dos postos e o resultado foi a fragmentação da execução da política. Entretanto, mesmo com menos poder e apoio político, havia pequenos grupos com o interesse em implementar o policiamento comunitário.

Se os grupos de interesse influenciaram nos bastidores da política e no processo de implementação de forma visível, havia conflitos com tentativas de interromper o processo que se iniciava de forma velada. As ações dentro da Secretaria e da PMDF tentavam diminuir o capital político e a aceitação por parte da sociedade civil da nova política.

Para analisar o processo de implementação e manutenção, optou-se por seguir com o arcabouço teórico de Kingdon (1984). A implementação dos pilares da política de segurança (postos policiais, mudança de práticas e participação da comunidade) necessitavam que as forças que originaram a política continuasse concatenados: que os indicadores começassem a favorecer o policiamento comunitário, que outras alternativas não fossem mais eficazes ou eficientes ou não oferecessem dispositivos mais atrativos para os atores políticos e que os humores políticos continuassem permitindo a implementação da política.

Para implementar o pilar da política de segurança pública destinado à mudança das práticas policiais, foi criado um sistema único de gestão na PMDF: um sistema híbrido com o policiamento tradicional e o policiamento comunitário. Neste sistema de policiamento foi verificado que havia concentração do planejamento acerca das ações policiais nas unidades. Os gestores e os subgestores dos postos comunitários não tinham autorização para planejar ações juntamente com a comunidade. E mais, não tinham autonomia para traçar metas. O sistema híbrido também atingiu esferas hierárquicas superiores. Os gestores e os subgestores se reúnem com oficiais superiores coordenadores lotados na SUPROC e na CPCDH, causando um desconforto nos comandantes dos batalhões locais e em oficiais responsáveis gestão do policiamento comunitário na PMDF.

Este desconforto presente em alguns comandantes também se reproduziu entre as praças. Grupos se sentiram desprestigiados e inseguros, pois até então suas práticas garantiam o reconhecimento mediado pela produtividade imediata da apreensão de armas, drogas e prisões e apreensões em flagrantes. O reconhecimento é fruto de forças 
resultantes próprias do campos social que molda o habitus e cria o tipo ideal de policial militar. Este reconhecimento no policiamento tradicional é imediato, já o policiamento comunitário pode apresentar resultados a médio e longo prazo, e o compartilhamento da responsabilidade pode compartilhar o reconhecimento do controle da criminalidade e da sensação de segurança.

O sistema híbrido de policiamento prejudicou a implementação do policiamento comunitário por não informar e demonstrar na prática à comunidade o que venha a ser a nova política na praxe de policiamento. Da mesma forma que o policial é um pedagogo e um formador da imagem do trabalho policial, o policial que está habituado a trabalhar no policiamento tradicional e não percebe o policiamento comunitário como uma tendência eficiente de diminuir a violência local desenvolveu práticas no trabalho que desvirtuaram a percepção da população acerca do policiamento comunitário.

O segundo pilar da política analisado foi o da instalação de posto policiais como provedor de segurança, cidadania e de referência da presença do Estado como parte do processo de aproximação da polícia com a comunidade local. O tipo de posto policial e sua instalação foram a parte visível que estava em desacordo com o projeto inicial. Havia a previsão de instalação dos postos seguindo um cronograma influenciado pelo quantitativo de policiais militares. Portanto, previa que só ia ser instalado uma unidade policial militar após o treinamento dos policiais que trabalhariam naquele posto. Outra questão relevante é quanto à qualidade da estrutura do posto policial: o projeto inicial previa posto semelhante a uma casa, já o que foi instalado foi apelidado de kinder-ovo como processo de ridicularização e desconstrução simbólica da política. Os postos instalados, em um primeiro momento, criaram ojeriza em policiais que estavam realizando policiamento ostensivo pela mudança abrupta da rotina, e em um segundo momento insatisfação por parte da população que deixou de ser atendida porque os policiais ficavam nos postos imobilizados.

O terceiro e último pilar já estava presente em algumas regiões administrativas. Todavia, a política de governo conseguiu instalar, mesmo que de forma precária, em todas as 30 (trinta) regiões. Entretanto, os Conselhos Comunitários de Segurança Pública continuaram sendo um espaço de conflito que desconstruía e/ou não permitia que se criassem laços comunitários. Atuar como um balcão de solicitação de serviço ou de prestação de informação descaracterizou a estratégia do policiamento comunitário para legitimar as práticas de prevenção e controle da criminalidade, a coparticipação da 
comunidade no processo de decisão de escolha das alternativas para a resolução dos problemas.

Foi observado que o processo de implantação da política não atingiu a meta mínima, a de instalar os postos comunitários e mantê-los em atividade, metas iniciais porque não se planejou e nem se analisou a relação quantidade de policiais militares por posto policial e durante o processo de formulação da política, não contemplava as possíveis complexidades culturais para mudar práticas arraigadas.

Cabe ressaltar que, durante a pesquisa, foi percebido que o habitus policial militar era apreendido de forma diferente pelos diversos grupos da Polícia Militar do Distrito Federal. Da mesma forma que o modelo ideal de policial militar resultante da interpretação dos grupos mediados pelo habitus construiu um ethos guerreiro, a gradação de apreensão do habitus possibilitou que outros pequenos grupos tivessem maior aderência à política pública, o que foi fomentado e catalisado pela utilização de redes que estavam constituídas nacional e localmente.

Esta pequena rede constituída por agentes de segurança permitiu que em alguns Postos Comunitários de Segurança o policiamento comunitário fosse apropriado e implementado de acordo com a interpretação do que fosse policiamento comunitário e de acordo com as características sócio-culturais local. Este processo se deu por ações individuais de membros da Suproc, da Senasp, de gestores de alguns postos comunitários e, em alguns lugares, de moradores próximo aos postos.

Os membros desta rede, tendo mais capital político e mantendo a convicção de que o policiamento comunitário era a melhor alternativa para o prevenção da criminalidade, tinha condições de implementar a política em outros PCS's. A reflexividade da ação policial comunitária iniciava uma tentativa de mudança na estrutura do campo social e do hábitus, todavia, sem os capitais necessários, fazem parte de apenas mais alguns poucos postos que deram certo.

Todavia, a convergência do fluxo que manteve a janela de oportunidade para a formação da agenda da política pública e sua implementação perdeu força. O principal ator político que detinha o capital político saiu do cenário político, os índices de criminalidade permanecem altos e a antiga solução ganha força novamente. A fase do abandono da política se inicia e está em processo de desconstrução total. A profecia do policial de que os postos poderiam virar ponto de entrega de pão e leite pode se concretizar nos próximos anos. 
Entretanto, a entrega dos PCS’s para outras Secretarias de Estado, como citou o policial militar há cinco anos atrás, não impossibilita o policiamento comunitário. As práticas das agências locais que formaram as Redes Sociais em Brazlândia e em Ceilândia demonstraram que a lógica da participação voluntária da comunidade nos problemas da cidade, sem um ente protagonista, mas com coparticipação e corresponsabilidade contribui para identificar problemas, analisar alternativas, implementar ações e analisar os resultados com muito maior eficiência que outras formas de interação e esta lógica de participação serve para outras áreas que desenvolveram políticas com o mesmo propósito do policiamento comunitário.

As descrições e análises do objeto da pesquisa trouxeram algumas certezas e dúvidas. As certezas estão ligadas ao modelo de análise de Kingdon. Há poucos momentos para a formação da agenda de segurança pública. O momento de confluência dos fluxos está ligada às eleições no Distrito Federal. Da mesma forma, a manutenção da política está ligada à manutenção do controle dos fluxos (problemas, solução e política).

Outra questão está relacionada às mudanças das práticas policiais militares cotidianas. Com características de instituição total (GOFFMAN, 1961), a Polícia Militar do Distrito Federal estabeleceu códigos de conduta para controlar as práticas da esfera pública e privada dos policiais militares. Além desta variável, havia barreiras sociais construídas, percebidas neste trabalho como muros sociais, que até então diminuíam a influência de outras instituições nas práticas diárias, principalmente pelo monopólio das soluções para as políticas públicas que as instituições policiais e militares detinham sobre segurança pública. Esse isolamento começou a ruir com a maior heterogeneidade dos policiais militares (por escolarização, por geração de formação profissional, por tendência a assumir riscos profissionais, entre outros).

Todavia, as redes sociais que foram estabelecidas institucionalmente e por pequenos grupos demonstraram as possibilidades de mudanças das práticas policiais militares. Entendemos que ao estudar os campos sociais e ao estudar o habitus ou as culturas institucionais, mapear as redes sociais que a instituição ou os indivíduos estabelecem é essencial para a compreensão das dinâmicas sociais e possiblidades das mudanças institucionais.

Quanto às dúvidas, que somente vieram com a ida a campo, mas que, por limitações do foco do olhar, ficou para futuras pesquisas. A participação de grupos motivados em redes nas questões da cidade tem um resultado mais eficaz e eficiente do 
que as políticas públicas setorizadas. Assim, resta saber o que impede que estas práticas se estabeleçam em outras cidades; ou ainda, se as agências do Estado têm as condições necessárias para estimular a criação destas redes e se estas redes são forças contrárias ao processo de individualização descrito por Durkheim ou ao processo de burocratização e de desencantamento vislumbrado por Max Weber. 


\section{REFERÊNCIAS}

AGENCIABRASIL. Rio de Janeiro inaugura Unidade de Polícia Pacificadora. Disponível em http://www.agenciabrasil.gov.br/noticias/2009/06/10/materia.2009-06-

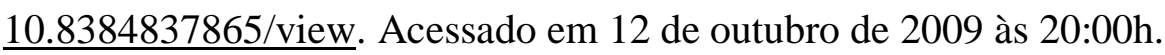

ALVARENGA FILHO, José Rodrigues de. “A chacina do Pan” e a reprodução de vidas descartáveis na cidade do Rio de Janeiro: "não dá pé não tem pé nem cabeça. Não tem ninguém que mereça. Não tem coração que esqueça”. Dissertação de Mestrado. Departamento de Psicologia. Universidade Federal Fluminense. 2010.

BANDEIRA, Lourdes e BATISTA, Anália Soria. "Preconceito e discriminação como expressões de violência.” Estudos Feministas, ano 10, 2002, pp 119-142

BAUMAN. Z. Comunidade. Rio de Janeiro: Jorge Zahar Editor. 2003

BAUMAN. Z. O Mal-Estar da Pós-Modernidade. Rio de Janeiro. Jorge Zahar Editor. 1998

BAYLEY, David H. Padrões de Policiamento: uma análise comparativa internacional. São Paulo. Editora Universidade de São Paulo. 2006

BELTRAME, José Mariano. Palavra do Secretário. Disponível em http://upprj.com/wp/?p=175. Acessado em 16 de dezembro de 2011.

BENNETT, Trevor. A polícia e o envolvimento do público na prestação de serviço do policiamento comunitário. In BROUDERU, Jean-Paul (org). Como reconhecer um bom policiamento comunitário. São Paulo: EDUSP. 2002

BERGER, Peter L. A construção Social da realidade: tratado de sociologia do conhecimento. Petrópolis. Editora Vozes. 2004

BOURDIEU, Pierre. Razões Práticas: Sobre a Teoria da Ação. Campinas. Papirus. 1996 A Economia das Trocas Simbólicas. São Paulo. Perspectiva. 2001

O Poder Simbólico. Rio de Janeiro: Ed. Bertrand Brasil, 2006. 
BRANDÃO, Helena H. Nagamine. Introdução à análise do Discurso. Campinas, SP. Editora Unicamp. 2002

BROUDEUR, Jean-Paul. Policiamento 'sob-medida': um estudo conceitual. In BROUDEUR, Jean-Paul (org.) Como reconhecer um bom policiamento comunitário. São Paulo: Edusp. 2002

CARDOSO, Marcus. Como Morre Um Projeto de Policiamento Comunitário: O Caso do Cantagalo e do Pavão-Pavãozinho. Tese de Doutorado. Universidade de Brasília.2005

CARDOSO DE OLIVEIRA, L. R. Concepções de Igualdade e (Des) Igualdades no Brasil. Série Antropológica . V 425, p. 6-19, 2009.

Honra, dignidade e Reciprocidade. Cadernos de Direitos Humanos, Rio de Janeiro, v. 1, n. 1, p. 31-48, 2004

CASTEL, Robert. A insegurança Social: o que é ser protegido?. Petrópolis. Editora Vozes. 2005

CERQUEIRA, C. M. N. O futuro de uma ilusão: o sonho de uma nova polícia. Rio de Janeiro: Freitas Bastos, 2001.

CERQUEIRA, C. M. N (org). Do patrulhamento ao policiamento comunitário. Rio de Janeiro: Fundação Ford/Freitas Bastos Editora, 1998.

COHEN, Lawrence e FELSON, Marcus. Social change and crime rate trends: a routine approach. [S.1]: American Sociological Review,1979. P. 64-65.

COHEN, M; MARCH, J; OlSEN, J. Garbage can model of organization choice. Admistrative Science Quartely. v. 17, n.1, p.15, 1972

CL. Câmara Legislativa. Segurança com Justiça Social é o Objetivo de Cabo Patrício. Editado por Marco Túlio Alencar. Acessado em 12.12.2014 no sítio http://www.cl.df.gov.br/en/ultimas-noticias/-/asset_publisher/IT0h/content/segurancacom-justica-social-e-objetivo-de-cabo-patricio

COSTA, Artur T. M. Reformas Institucionais e as Relações entre a polícia e a sociedade em Nova Iorque. In: Sociedade e Estado. Brasília, v19, n. 1. EdUnb. 1994.

Entre a Lei e a Ordem: violência e reforma nas polícias do Rio de Janeiro e Nova Iorque. Editora FGV. 2004

É possível uma Política Criminal? A discricionariedade no Sistema de Justiça Criminal do DF. In: Sociedade e Estado. Brasília, V26, n.1. EdP. 2011. 
DYE, Thomas. Mapeamento dos modelos de análise de políticas públicas. In: HEDEMANN, F.; SALM, J. (Orgs.). Políticas públicas e desenvolvimento: bases epistemológicas e modelos de análise. Brasília: Editora Universidade de Brasília, 2. ed., p. $97-129,2010$

DIAS, Reinaldo \& MATOS, Fernando. Políticas Públicas: Princípios, propósitos e processos. São Paulo. Atlas, 2012.

DURKHEIM, Émile. A divisão social do trabalho: São Paulo: Martins Fontes, 2000a O Suicídio. São Paulo: Martins Fontes. 2000b

ELIAS, Norbert. O Processo Civilizador. Rio de Janeiro: Jorge Zahar Editor, 1994

FARIA, Carlos; FILGUEIRAS, Cristina. As políticas dos sistemas de avaliação da educação básica do Chile e do Brasil. In: HOCHMAN, G.; ARRETCHE M.; MARQUES, E. (Orgs.) Políticas públicas no Brasil. Rio de Janeiro: Editora Fiocruz, p. 327-367, 2007.

FEITOSA et all. Projeto do Programa Comunitário de Referência Social. Brasilia. 2006

FBSP. Ata de Constituição do Fórum Brasileiro de Segurança Pública. $10^{\circ}$ Oficial de Registro Civil de Pessoa Jurídica da Capital. São Paulo. 2007.

Estatuto Social do Fórum Brasileiro de Segurança Pública. $10^{\circ}$ Oficial de Registro Civil de Pessoa Jurídica da Capital. São Paulo. 2012.

FERNANDES, Florestan. O negro no mundo dos brancos. São Paulo. Difusão Européia do Livro. 1979.

. Elementos de sociologia teórica. São Paulo. Editora Nacional

e Editora da USP. 1970

FILHO, Claudio C. Beato. Políticas públicas de segurança e a questão policial. São Paulo em Pespectiva. Volume 13, nº 04. 1999

FOUCAULT, Michel. Vigiar e Punir. Petrópolis: Vozes, 1987 .Microfisica do Poder: Graal, 1985 
A Ordem do Discurso. São Paulo: Loyola, 1995.

FREY, Klaus. Políticas Públicas: um debate conceitual e reflexões referentes à prática da análise de políticas públicas no Brasil. Planejamento e políticas públicas. No. 21. 2000.

GARLAND, David. Crimen y ordem social em la sociedad contemporânea. La cultura del control. Editorial Gedisa. 2001.

GIDDENS, Anthony. As consequências da modernidade. São Paulo Editora UNESP, 1991.

GOFFMAN, Erving. Manicômios, Prisões e Conventos.. São Paul,o Editora Perspectiva. 1961

A Representação do Eu na Vida Cotidiana. Petrópolis. RJ: Vozes. 1975.

giuliani, M. Livello del gioco. In: CAPANO, G; GIULIANI, M. Dizionario di Politiche Pubbliche. Roma: Carocci, 2005.

HAGUETTE, Teresa Maria Frota. Metodologias qualitativas na sociologia. Petrópolis, RJ. Editora Vozes. 1989

HOLLOWAY, Thomas. Polícia no Rio de Janeiro: repressão e resistência numa cidade do século XIX. Rio de Janeiro. Editora FGV, 1997.

INSTITUTO NÃO A VIOLENCIA. Programas. Acessado em 13.12.2014 no sítio http://www.naoviolencia.org.br/programas.htm.

KANT DE LIMA, Roberto. A polícia da cidade do Rio de Janeiro: seus dilemas e paradoxos. Rio de Janeiro: Editora Forense. 1995

KING, A. On studying the impacts of public policies: the role of the policital scientist. In: Holden Jr., M., e Dresang, D., eds. What government does. Beverly Hill, Sage, 1975, pp. 298-316. 
KINGDON, John. Agendas, alternatives and public policies. Boston, Little Brown, 1984.

LASSWELL, Harold. The decision process: seven categories of functional analysis. College Park: University of Maryland Press, 1956.

LÉVI-STRAUSS, Claude. O Cru e o Cozido (Mitológicas v.1). São Paulo. Cosac \& Naif. 2004

LIMA, Renato Sério de (Coord) et all. Finanças Públicas e o Papel dos Municípios na Segurança Pública. Fórum Brasileiro de Segurança Pública. São Paulo, 2012

MACHADO, Paes Eduardo e NORONHA, Ceci Vilar. "A polícia dos pobres: violência policial em classes populares urbanas.” Sociologias, Porto, ano 4, n⿳ 7, 2002, pp 188-221

MAFFESOLI, Michel. Lógica da Dominação, Rio de Janeiro: Zahar, 1978

MICHAUD, Yves. A Violência., São Paulo: Editora Ática, 2001.

MONTEIRO, Jorge Vianna. Fundamentos da política pública. Rio de Janeiro. IPEA. 1982.

MOON, M. J.; INGRAHAM, P. Shaping administrative reforms and governance: na examination of the political nexus triad in three Asian countries. Governance, v. 11, n. 1, p 77-100, 1998.

MORAES, Luciane Patrício Braga de. Falar, ouvir e escutar: Etnografia dos processos de produção de discursos e de circulação da palavra nos rituais de participação dos conselhos comunitários de segurança. 2011. Tese (Doutorado) - UFF, Niterói - RJ.

MUNIZ, Jacqueline. (1999). Ser Policial É Sobretudo Uma Razão de SER: Cultura e Cotidiano da Polícia Militar do Estado do Rio de Janeiro. IUPERJ, Tese de Doutorado.

- NETO, Miguel Libório Cavalcante. Desenvolvimento do policiamento comunitário no Estado de São Paulo: análises e perspectivas para o futuro. São Paulo: CSP, 1998.

NEV. Núcleo de Estudos da Violência. Universidade de Brasília. Acessado em dezembro de 2014 no sítio http://www.nevusp.org/portugues/index.php?option=com_frontpage\&Itemid=1.

PEIRANO, Mariza. A Favor da Etnografia. Rio de Janeiro. Relume-Dumara. 1995 
PETER, Gabriel. O Social Entre o Céu e o Inferno: A Antropologia Filosófica de Pierre Bourdieu. Tempo Social. V.24 n1.

ROSENBAUM, Dennis. A mudança no papel da polícia: Avaliando a transição para o policiamento comunitário. In BROUDERU, Jean-Paul (org). Como reconhecer um bom policiamento comunitário. São Paulo: EDUSP. 2002

RODRIGUES, José Nivaldino. PLACAR DA VIDA: UMA ANÁlISE DO PROGRAMA "PAZ NO TRÂNSITO" NO DISTRITO FEDERAL. Dissertação de Mestrado. Universidade de Brasília. 2007

SÃO PAULO. Operação Braços Abertos terá novas ações organizadas pela prefeitura. Acessado em http://www.prefeitura.sp.gov.br/cidade/secretarias/subprefeituras/se/noticias/?p=45815 no dia 27 de fevereiro de 2014.

SANTOS, José Vicente Tavares dos. "A violência como dispositivo de excesso de poder". Sociedade e Estado. Revista Semestral de Sociologia. Volume X, no 2, pp281298.

SILVA. G. Gomes da. A lógica da PMDF na construção do Suspeito. Dissertação de Mestrado. Departamento de Sociologia. Universidade de Brasília. 2009ª

Policiamento Comunitário: um estudo de caso no Distrito Federal. Monografia de Conclusão de Curso de Especialização em Segurança Pública. UNISUL. 2009b

A Identidade e o Sofrimento Policial Militar: Entre o Público e o Privado. Monografia de Conclusão de Curso de Graduação em Antropologia. Universidade de Brasília. 2011.

As (des) Informações Como Mediadoras de Políticas de Segurança Pública. Trabalho de Conclusão de Curso de Especiação em Análise Criminal. Universidade Católica de Brasília. 2014

SENASP. Diagnóstico da Perícia Criminal no Brasil. Brasília. 2012

.Perfil das Instituições de Segurança Pública. Brasília. 2013a

Mulheres nas Instituições de Segurança Pública. Brasília. 2013b

. Cursos de Pós-Graduação em Segurança Pública e a Construção da RENAESP como Política Pública: Considerações sobre seus efeitos a partir de diferentes olhares. Brasília. 2014

SIMMEL, G. A. D. Sociologia. Organização de Evaristo Filho. São Paulo: Ática, 1983. 
SJÖBLOM, G. Problemi e soluzoni in politica. Rivista Italiana di Scienza Politica, v. 14, n. 1, p. 41-85, 1984.

SKOLNICK, Jerome H. e BAYLEY, David H. Policiamento Comunitário. São Paulo: USP, 2002.

SKOLNICK, Jerome H. e BAYLEY, David H. Nova Polícia: Inovação na polícia de seis cidades norte-americanas. São Paulo: USP, 2001.

SOARES, J. R. Think tanks: organização sistêmica de conhecimentos relevantes a política pública no Brasil. Dissertação. Programa de Pós-Graduação em Administração, Universidade do Estado de Santa Catarina (Udesc), Florianópolis, 2009.

SOUZA, Celina. "Estado de Campo" da pesquisa em políticas públicas no Brasil. Revista Brasileira Ciências Sociais. Vol. 18 número 51. São Paulo. 2003

TSE. Tribunal Superior Eleitoral: Relatório de eleição 2006. Acessado em 12.12.2014 no sítio http://www.tse.jus.br/eleicoes/eleicoes-anteriores/eleicoes-2006/resultado-daeleicao-2006.

SOUZA, Celina. Políticas Públicas, uma revisão da literatura. Sociologias. Número 16. Porto Alegre. 2006

TEIXEIRA, Maria Cecília Sanches e PORTO, Maria do Rosário Silveira. "Violência, insegurança e imaginário do medo.” Cadernos Cedes, ano XIX, nº 47, 1998

UNODC. Gestão e Governança da Segurança Pública do Distrito Federal e Entorno.

Nívio Caixeta do Nascimento (Coord). Brasília, 2001.

VASCONCELOS, Ana Maria Nogales \& COSTA, Athur. Demografia da Violência no Distrito Federal: Evolução e Características. In PAVIANI, Aldo et all. (org) Brasília: Dimensões da Violência Urbana. Editora Universidade de Brasília. 2005

VEJA. Sem limites para a barbárie. Marcelo Bortoloti. Acessado em http://veja.abril.com.br/140207/p_046.shtml em 20.01.2014.

VIEIRA, Carolina Luíza Sarkis. A Invenção da Comunidade: participação, política e exclusão nos Conselhos Comunitários de Segurança das Regiões Administrativas do Distrito Federal. 2007. Dissertação (Mestrado) - UNICEUB. Brasília - DF, 